\title{
INTELIGENCJA W CODZIENNYM ŻYCIU
}

\author{
REDAKCJA
}

Marcin Zajenkowski

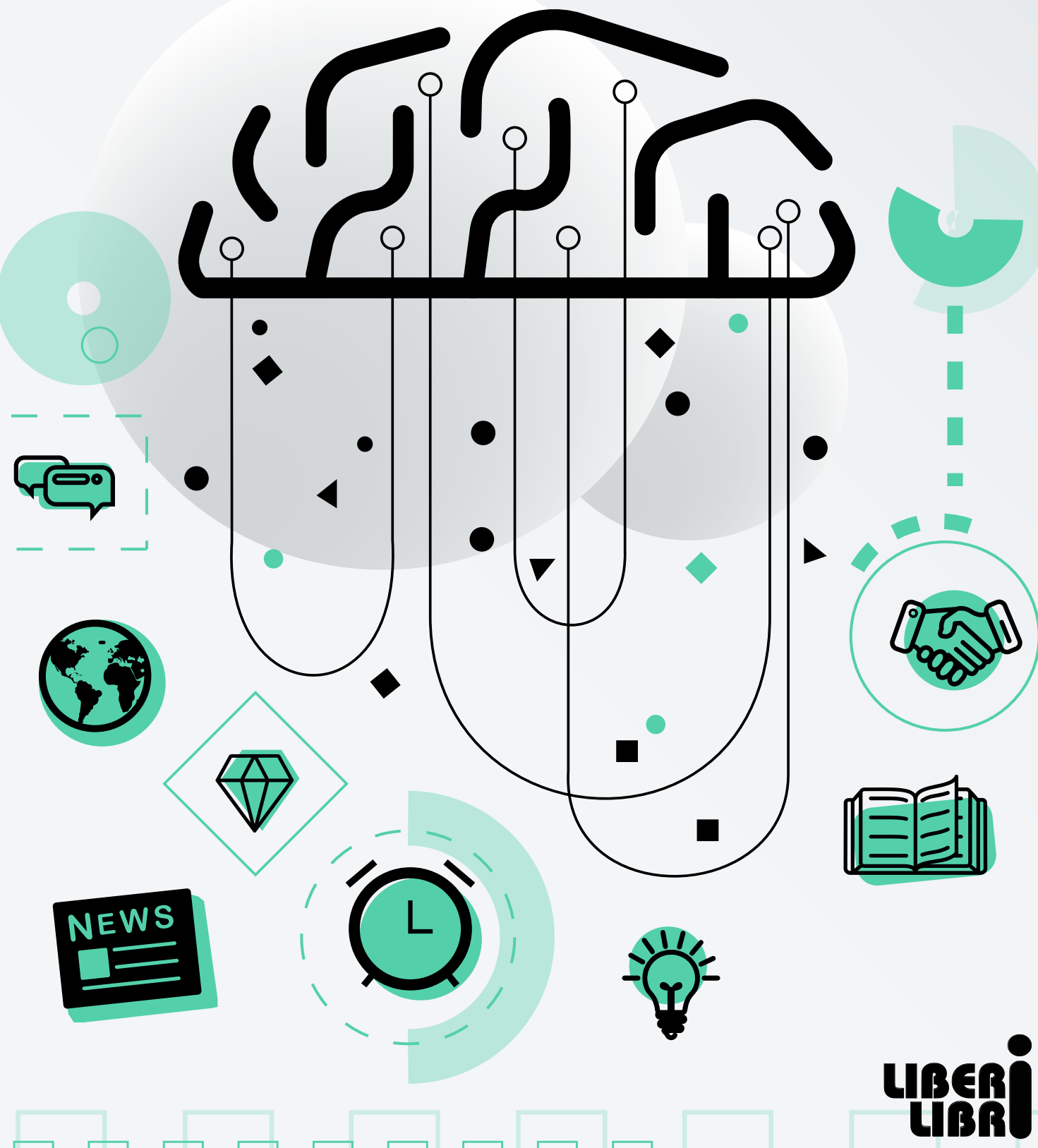




\title{
INTELIGENCJA W CODZIENNYM ŻYCIU
}

\author{
REDAKCJA \\ Marcin Zajenkowski
}





\title{
INTELIGENCJA W CODZIENNYM ŻYCIU
}

\author{
REDAKCJA \\ Marcin Zajenkowski
}


Inteligencja w codziennym życiu

Redakcja naukowa: Marcin Zajenkowski

\section{Recenzenci:}

dr hab. Maciej Karwowski, prof. uczelni (UWr)

ks. dr hab. Waldemar Klinkosz, prof. uczelni (UKSW)

\section{Projekt okładki:}

Dominika Karaś

Ilustracja na okładce:

ravamotiondesign.com

Korekta językowa:

Małgorzata Najderska

Skład i łamanie:

Justyna Harasimczuk

Publikacja jest udostępniona na licencji Creative Commons Uznanie autorstwa 4.0. Treść licencji jest dostępna na stronie: https://creativecommons.org/licenses/ by/4.0/

Publikacja finansowana $z$ projektu finansowanego z Narodowego Centrum Nauki nr 2016/23/B/HS6/00312

Warszawa: Wydawnictwo Liberi Libri, 2021

www.LiberiLibri.pl

ISBN: 978-83-63487-51-5

DOI: $10.47943 /$ lib. 9788363487515 


\section{SPIS TREŚCI}

6 0.1. Wprowadzenie - Marcin Zajenkowski

8 0.2. Kilka słów o korelacji - Marcin Zajenkowski

\section{CZĘŚĆ I.}

\section{INTELIGENCJA I ZDOLNOŚCI POZNAWCZE A EFEKTYWNA ADAPTACJA DO} ŚRODOWISKA

13 1. Inteligencja: ogólna zdolność o praktycznym znaczeniu dla szkoły, pracy, zdrowia i długości życia - Marcin Zajenkowski

33 2. Jak inteligentnie kontrolować swoje zachowania? Siła woli w życiu codziennym - Jan Jędrzejczyk

69 3. Inteligencja a agresja. Czy wysokie IQ może uchronić przed wkroczeniem na ścieżkę przestępczą? - Marta Bodecka

89 4. Funkcjonowanie poznawcze w uzależnieniach behawioralnych - Iwona Nowakowska, Karolina Lewandowska, Karol Lewczuk

\section{CZEŚĆĆ II.}

\section{INTELIGENCJA I ZDOLNOŚCI POZNAWCZE A EMOCJE I PRZEKONANIA}

133 5. Przekonania na temat inteligencji, czyli kto i dlaczego chce być (postrzegany jako) mądry - Marcin Zajenkowski, Oliwia Maciantowicz

159 6. „Nie taki diabeł straszny...” - czyli poznawcze konsekwencje gniewu i ich motywacyjne podłoże - Kinga Szymaniak

185 7. Rozum czy serce? O powiązaniach pomiędzy zdolnościami poznawczymi i społeczno-emocjonalnymi a religijnością - Paweł Łowicki

207 8. Inteligentne metapoznanie, czyli jak wiedza o własnym umyśle może być przydatna w codziennym życiu - Maria Ledzińska

\section{CZĘŚĆ III.}

\section{INTELIGENCJA I ZDOLNOŚCI POZNAWCZE A SPECYFICZNE OBSZARY ŻYCIA}

233 9. Inteligentny sport: o związkach inteligencji z aktywnością fizyczną i poziomem wykonania sportowego - Wojciech Waleriańczyk, Maciej Stolarski

259 10. Sprawność intelektualna osób o odmiennych chronotypach - Konrad Jankowski

275 11. Inteligencja a funkcjonowanie w bliskich związkach - Maria Leniarska, Marcin Zajenkowski 


\section{WPROWADZENIE}

Jedna z najczęściej pojawiających się w literaturze definicji inteligencji opisuje ja jako zdolność, która ułatwia człowiekowi przystosowanie do środowiska. Badania psychologiczne prowadzone już od drugiej połowy XIX w. (m.in. przez Francisa Galtona) zdają się potwierdzać adaptacyjny charakter inteligencji. Od samego początku badacze łączyli sprawność intelektualna z funkcjonowaniem szkolnym. W kontekście badania uczniów szkoły średniej zrodziła się koncepcja czynnika inteligencji ogólnej zaproponowana przez Charlesa Spearmana. Nowo powstałe testy inteligencji u progu XX w., początkowo stworzone dla celów edukacyjnych przez Alfreda Bineta, szybko wzbudziły zainteresowanie pracodawców, ponieważ stanowiły efektywne narzędzie wyboru najlepszych kandydatów do pracy. Proces rozpowszechniania się testów inteligencji przyspieszyła I wojna światowa i potrzeba szybkiej selekcji kandydatów do służby wojskowej na różnych stanowiskach. Szkoła i praca, niewątpliwie ważne obszary aktywności człowieka, nie wyczerpuja jednak dziedzin, w których inteligencja okazała się ważna. Późniejsze badania, prowadzone m.in. przez zespół szkockiego badacza Iana Deary’ego, pokazały znaczenie inteligencji dla zdrowia i długości życia. Inteligencja jest ogólną zdolnością, która przesądza o sprawności funkcjonowania poznawczego człowieka. Praktycznie każda aktywność ludzka angażuje w jakimś stopniu procesy poznawcze. Nie dziwi zatem fakt, że inteligencja ma znaczenie w niemal każdej sferze życia, od samoregulacji, osobowości, przekonań o świecie, kontroli niepożądanych zachowań i emocji, po aktywność fizyczną, preferencje dobowe i funkcjonowanie w związkach. W niniejszym zbiorze przyglądamy się niektórym z tych obszarów, wskazując na różnorodność wątków związanych z inteligencją.

Teksty zawarte w zbiorze prezentują wyniki badań nad inteligencją i szeroko rozumianym funkcjonowaniem poznawczym w odniesieniu do kilku sfer życia codziennego. Prezentowane zagadnienia były podejmowane w Pracowni Badań nad Inteligencją i Procesami Emocjonalno-Poznawczymi (Intelligence-Cognition-Emotion Lab) na Wydziale Psychologii Uniwersytetu Warszawskiego. Poszczególne rozdziały przedstawiaja wyniki badań prowadzonych przez członków Pracowni lub osób z nią współpracujących. Część prezentowanych badań i zagadnień jest wynikiem projektu finansowanego z Narodowego Centrum Nauki (nr 2016/23/ B/HS6/00312) pt. Gniew i poznanie. Poszukiwanie zwiazków i mechanizmów w badaniach psychometrycznych i eksperymentalnych. Treść zbioru została podzielona na trzy główne części. 
W pierwszej części książki znalazły się rozdziały odwołujące się bezpośrednio do adaptacyjnego charakteru inteligencji oraz związanymi z nią funkcjami poznawczymi. Pierwszy rozdział autorstwa Marcina Zajenkowskiego stanowi wprowadzenie do całego zbioru i przedstawia rys historyczny dociekań nad inteligencją, jej definicję oraz przegląd badań nad znaczeniem inteligencji dla osiagnięć szkolnych, funkcjonowania w pracy oraz zdrowia i długości życia. Następne trzy rozdziały opisują rolę zdolności poznawczych dla adaptacyjnego zachowania w zakresie samoregulacji (Jan Jędrzejczyk), agresywnego zachowania (Marta Bodecka) oraz uzależnień (Iwona Nowakowska, Karolina Lewandowska, Karol Lewczuk).

Druga część zbioru obejmuje teksty, w których przedyskutowano związki inteligencji i zdolności poznawczych z przekonaniami i emocjami. Marcin Zajenkowski i Oliwia Maciantowicz wskazują na wagę przekonań o własnej inteligencji dla różnych obszarów życia. Kinga Szymaniak przedstawia badania nad związkami gniew-poznanie, wskazując na najnowsze teorie $\mathrm{z}$ zakresu psychologii emocji. Paweł Łowicki omawia powiązania inteligencji i zdolności emocjonalno-społecznych z przekonaniami religijnymi. Maria Ledzińska prezentuje obszerny przegląd badań nad metapoznaniem, a więc wiedzą na temat własnych procesów poznawczych, jej związkami z inteligencją i codziennym funkcjonowaniem.

W trzeciej części zbioru przedstawiono rozdziały opisujące rolę inteligencji w specyficznych obszarach życia. Wojciech Waleriańczyk i Maciej Stolarski zebrali informacje na temat roli inteligencji w sporcie. Konrad Jankowski przedstawia badania nad związkami zdolności poznawczych z chronotypem, cechą opisująca preferencje pory dnia dla aktywności człowieka. W ostatnim rozdziale Maria Leniarska i Marcin Zajenkowski dokonuja przeglądu badań nad inteligencją ogólną oraz inteligencją emocjonalną i funkcjonowaniem osób w bliskich zwiazkkach.

Niniejszy zbiór przedstawia badania nad inteligencją w różnych obszarach życia. Rozległość podejmowanych wątków wskazuje na doniosłe znaczenie zdolności poznawczych dla codziennej aktywności człowieka. Dobór tekstów stanowi pewną reprezentację tematów podejmowanych w psychologii i oczywiście nie wyczerpuje wszystkich dziedzin, w których inteligencja odgrywa ważna rolę. Mamy nadzieję jednak, że książka może stanowić dobre wprowadzenie w tematykę inteligencji i wskazywać bardziej szczegółowe teksty źródłowe. 


\section{KILKA SŁÓW O KORELACJI}

\section{Marcin Zajenkowski}

\section{Uniwersytet Warszawski, Wydział Psychologii}

Badania nad inteligencją są często prowadzone w tzw. nurcie psychometrycznym, w którym kluczową rolę odgrywa korelacja jako metoda analizy statystycznej. Podobnie w niniejszym zbiorze niejednokrotnie wspominamy o korelacji (czy związku) pomiędzy poziomem inteligencji a innymi zmiennymi, np. ocenami szkolnymi, zarobkami czy zachowaniami agresywnymi. Zmienne to dowolne właściwości przypisywane ludziom lub obiektom, które moga przybierać różne wartości. Korelacja zaś to miara tego, w jakim stopniu dwie zmienne są ze sobą powiązane. Innymi słowy, korelacja opisuje, jak uporządkowane są dwie zmienne względem siebie.

Wyobraźmy sobie, że chcemy zbadać związek pomiędzy poziomem inteligencji a zarobkami wśród pracowników pewnej firmy. Aby to policzyć, musimy uzyskać od każdej osoby informacje o jej inteligencji (np. poprosić ją o rozwiązanie testu inteligencji) oraz zapytać ją o miesięczną wysokość zarobków. Dysponując informacją o tych dwóch wynikach od wszystkich pracowników w firmie, możemy następnie uporządkować ich wyniki pod względem jednej zmiennej, np. inteligencji, od najmniejszego do najwyższego, a następnie sprawdzić, w jakim stopniu wyniki drugiej zmiennej układają się względem tej pierwszej. Korelacja wyraża siłę i kierunek powiązania tych dwóch zmiennych.

Korelacja może przyjmować wartości od -1 do 1 . Wartości te wyrażają siłę korelacji. Wartość 0 oznacza brak związku pomiędzy badanymi zmiennymi, to znaczy, że nie da się zauważyć żadnej prawidłowości pomiędzy zmiennymi. Wartości różne od 0 wyrażaja pewien stopień uporządkowania wyników dwóch zmiennych. Im bliżej wartości 1 (niezależnie od znaku), tym silniejsza korelacja. Przykładowo, korelacja równa 0,10 jest stosunkowo słaba, natomiast korelacja $-0,90$ jest bardzo silna.

Znak towarzyszący korelacji (dodatni lub ujemny) wskazuje na kierunek związku. Korelacja dodatnia oznacza, że wraz ze wzrostem wartości jednej zmiennej, rosną wartości drugiej zmiennej. Przykładowo, dodatnia korelacja pomiędzy inteligencją a zarobkami oznacza, że im wyższa inteligencja pracowników, tym wyższe zarobki. Wyobraźmy sobie, że wybieramy pięciu pracowników z firmy i uporządkowujemy ich wartości pod względem inteligencji 
od najmniejszej do największej, tak jak pokazano to w tabeli 1. Widzimy, że średnia ocen dla każdego ucznia układa się podobnie do inteligencji, a więc rosnąco. Mamy tu do czynienia z korelacją dodatnią wynosząca 1, ponieważ jest to idealne uporządkowanie dwóch zmiennych.

Tabela 1. Pryylktad korelacii pomiedsy IQ a miesiecznymi zarobkami pracownikón

\begin{tabular}{ccc}
\hline Osoba & IQ & $\begin{array}{l}\text { Miesięczne } \\
\text { zarobki (zł) }\end{array}$ \\
\hline 1 & 95 & 3500 \\
\hline 2 & 100 & 4000 \\
\hline 3 & 105 & 4500 \\
\hline 4 & 110 & 5000 \\
\hline 5 & 115 & 5500 \\
\hline
\end{tabular}

Korelację można również przedstawić za pomocą wykresu. Na przykład dane z tabeli 1 można przedstawić graficznie, tak jak zrobiono to na rysunku 1. Każdy punkt reprezentuje osobę, oś pozioma $(\mathrm{X})$ przedstawia IQ, natomiast oś pionowa $(\mathrm{Y})$ przedstawia miesięczne zarobki. Jak widać, punkty wyraźnie układają się linię, stąd też tego typu korelacje nazywa się liniowymi. Są to najczęściej analizowane związki między zmiennymi.

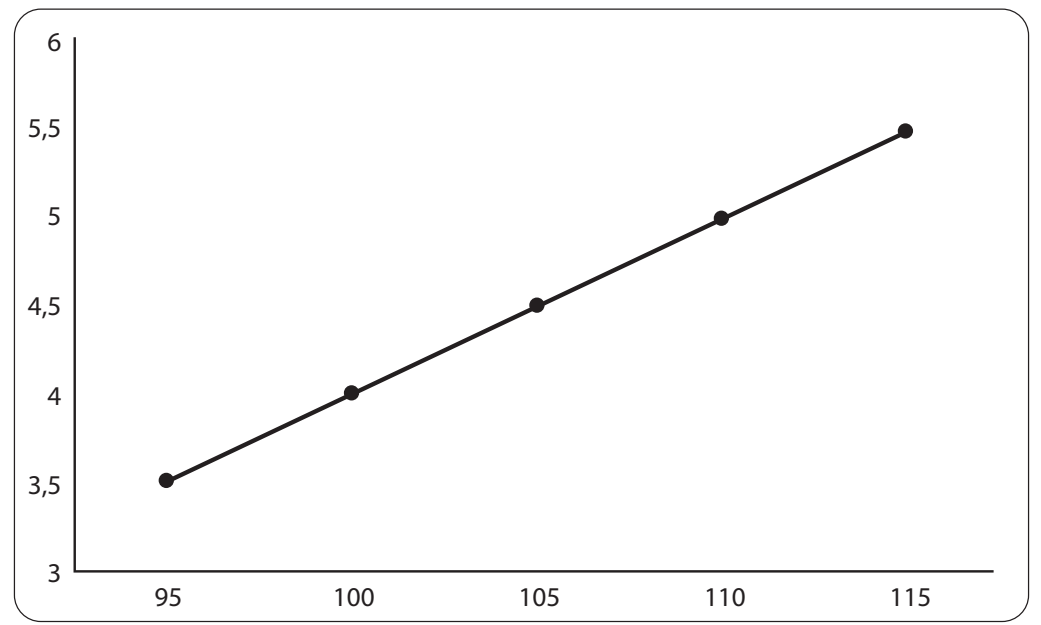

Rysunek 1. Korelacja pomiędry IQ (oś X) a zarobkami w tys. żt (oś Y) pieciu osób. 
Przykładem korelacji ujemnej może być związek poziomu inteligencji z lękiem egzaminacyjnym. Wyobraźmy sobie, że znów przebadaliśmy pięciu uczniów, tym razem testem inteligencji oraz kwestionariuszem mierzącym poziom lęku przed egzaminem (na skali od 1 - niski leke, do 5 - silny lęe). Następnie porządkujemy zmienne tak jak w tabeli 2. Lęk układa się odwrotnie względem IQ, to znaczy, że im wyższy poziom IQ, tym niższy lęk. Mamy zatem do czynienia z korelacją idealnie ujemną równą -1.

Tabela 2. Pryyktad korelacii pomiedsy IQ a lekiem przed egzaminem

\begin{tabular}{ccc}
\hline Osoba & IQ & Lęk \\
\hline 1 & 95 & 5 \\
\hline 2 & 100 & 4 \\
\hline 3 & 105 & 3 \\
\hline 4 & 110 & 2 \\
\hline 5 & 115 & 1 \\
\hline
\end{tabular}

Jak łatwo sobie wyobrazić, wykres danych przedstawionych w tabeli 2 będzie układał się odwrotnie niż na rysunku 1, czyli tak jak przedstawiono na rysunku 2.

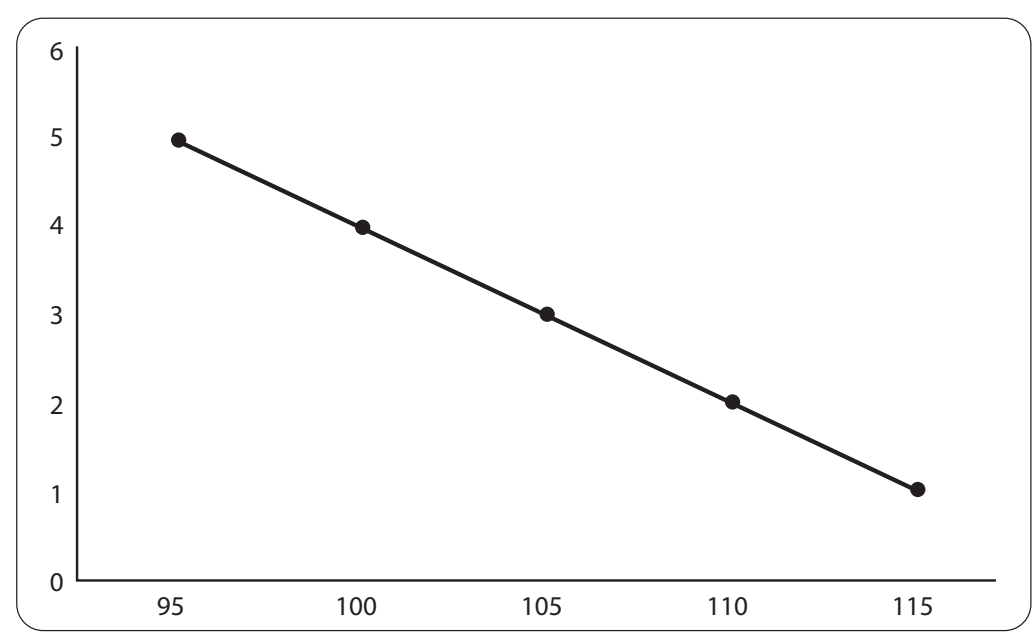

Rysunek 2. Korelacja pomiedsy IQ (oś X) a lekiem przed egzaminem (oś Y) pieciu osób. 
Kolejne zagadnienie dotyczy interpretacji wielkości korelacji. W klasycznym ujęciu, zaproponowanym przez Cohena (1988), korelacje 0,10, 0,30 i 0,50 interpretowano jako, odpowiednio, niską, średnią i wysoką. Jednakże niedawna metaanaliza ujawniła, że w zakresie badań nad różnicami indywidualnymi, a więc również i w badaniach na inteligencją, zazwyczaj uzyskuje się znacznie mniejsze korelacje (Gignac, Szodorai, 2016). I tak, wielkości rzędu 0,11, 0,19 i 0,29 oznaczają, odpowiednio, niską, średnią i wysoką korelację.

W tym miejscu można wspomnieć jeszcze o pojęciu metaanalizy, które również pojawia się we współczesnych badaniach psychologicznych. Metaanaliza jest to wynik uogólniony z wielu (kilkudziesięciu lub nawet kilkuset) pojedynczych badań. Na przykład metaanaliza związku inteligencji z osiagnięciami szkolnymi może polegać na zebraniu wszystkich (lub przynajmniej sporej ich części) opublikowanych badań na ten temat, a następnie obliczeniu uśrednionej korelacji pomiędzy tymi zmiennymi. W tym celu używa się odpowiednich procedur statystycznych, które biora pod uwagę wielkość poszczególnych prób badanych oraz różne możliwe zniekształcenia, np. związane z tendencją do publikowania jedynie istotnych wyników (tzw. publication bias). Ponieważ pojedyncze badanie niesie ze sobą ryzyko tego, że mogą w nim znaleźć się nietypowe osoby, metaanaliza pozwala na bardziej pewne wnioski pochodzące z wielu badań, co częściowo eliminuje efekt specyficznej próby lub np. konkretnego badacza.

$\mathrm{Na}$ koniec warto zwrócić uwagę na jeszcze jedną kwestię. Badania korelacyjne najczęściej traktuje się jako „słabsze” niż badania eksperymentalne, jeżeli chodzi o wyciaganie wniosków przyczynowo-skutkowych. Korelację można policzyć wtedy, gdy dysponuje się informacjami o wartościach dwóch zmiennych. Te dwie zmienne można wybrać zupełnie dowolnie, nawet jeżeli teoretycznie nic ich nie łączy. Co więcej, można nawet otrzymać wysoką siłę korelacji pomiędzy, wydawałoby się, przypadkowymi zmiennymi. Dlatego też badacze postulują ostrożność w wyciaganiu daleko idących wniosków o kierunku zależności na podstawie badań korelacyjnych. Na przykład wysoka korelacja pomiędzy poziomem IQ a osiagnięciami szkolnymi może być tłumaczona na dwa sposoby. Z jednej strony, inteligencja może wpływać na osiagnięcia szkolne uczniów, z drugiej zaś, szkoła może stymulować rozwój inteligencji. Badacze szukają zatem dodatkowych informacji i metod, aby uwiarygodnić swoje interpretacje. Pomimo tego, że w interpretacji korelacji zaleca się ostrożność, niektórzy zwracają uwagę na to, że czasami mocne podłoże teoretyczne badań korelacyjnych pozwala na bardziej kierunkowe wnioski na temat zależności przyczynowych pomiędzy zmiennymi (np. Grosz, Rohrer, Thoemmes, 2020). 


\section{BIBLIOGRAFIA}

Cohen, J. (1988). Statistical power analysis. Hillsdale: Erlbaum.

Gignac, G. E., Szodorai, E. (2016). Effect size guidelines for individual differences researchers. Personality and Individual Differences, 102, 74-78. https://doi. org/10.1016/j.paid.2016.06.069

Grosz, M. P., Rohrer, J. M., Thoemmes, F. (2020). The taboo against explicit causal inference in nonexperimental psychology. Perspectives on Psychological Science, 15(5), 1243-1255. https://doi.org/10.1177/1745691620921521 


\section{1.}

Inteligencja: ogólna zdolność o praktycznym znaczeniu dla szkoły, pracy, zdrowia i długości życia

Marcin Zajenkowski iD https://orcid.org/0000-0001-8669-4231

Uniwersytet Warszawski, Wydział Psychologii

zajenkowski@psych.uw.edu.pl 
$\mathrm{I}$ nteligencja jest bardzo popularnym pojęciem we współczesnym świecie. Ludzie często łączą ją z umiejętnościami czysto szkolnymi czy akademickimi, znajdującymi zastosowanie przede wszystkim w kontekście sukcesu edukacyjnego. Jak się jednak okazuje, inteligencja łączy się z sukcesem w wielu dziedzinach życia, włączając w to efektywność w pracy, a nawet, jak pokazuja ostatnie badania, z dobrym zdrowiem i dłuższym życiem. Dodatkowo spośród różnych zmiennych psychologicznych, inteligencja, jako jedna z nielicznych, łączy się tak silnie i z tak wieloma obszarami życia. W niniejszym rozdziale przyglądamy się pojęciu inteligencji jako bardzo ogólnej zdolności, która okazuje się mieć duże znaczenie praktyczne zarówno w kontekście szkoły, pracy i zdrowia, jak i zwykłych czynności dnia codziennego.

\section{INTELIGENCJA: BARDZO OGÓLNA ZDOLNOŚĆ O DUŻYM PRAKTYCZNYM ZNACZENIU}

Badania nad inteligencja podejmowano już w drugiej połowie XIX w. (np. Galton, 1869), czyli niemal od samego początku istnienia psychologii jako odrębnej nauki. Jednakże jedno z najbardziej przełomowych odkryć związanych z intelektem miało miejsce na początku XX w. Charles Spearman (1904) przy użyciu pionierskich metod analiz danych, takich jak analiza czynnikowa, zauważył, że poziom wykonania różnych zadań poznawczych jest dodatnio skorelowany. Innymi słowy, ludzie mają tendencję do uzyskiwania podobnych wyników (niskich, średnich lub wysokich) w zakresie dowolnych testów, które angażuja zdolności poznawcze. Istnieje zatem spora szansa, że ktoś, kto ma wysoki wynik w zadaniach matematycznych, będzie uzyskiwał również wysoki wynik w zadaniach z zakresu biologii, znajomości słów, zapamiętywania długich ciągów liczbowych czy też rozumienia zasad społecznych. Dodatnia korelacja oznacza również, że osoby o niskim wyniku w danym typie zadań, będa na ogół wykonywały gorzej także inne zadania poznawcze. Ta ogólna skłonność ludzi do przejawiania pewnego poziomu funkcjonowania intelektualnego została przez Spearmana (1904) nazwana czynnikiem $g$. Nazwa pochodzi od angielskiego słowa general, które miało oddawać stopień ogólności opisanego 
czynnika. Zdaniem Spearmana, czynnik $g$ nie jest jedynie statystyczną abstrakcją, ale realnie istniejącą cechą zwaną tradycyjnie inteligencją ogólną. Czynnik $g$ reprezentuje ogólną sprawność intelektualną człowieka, która zaangażowana jest w niemal każdą aktywność poznawcza. Oprócz inteligencji ogólnej (czynnika g), Spearman wyróżnił także szereg zdolności specyficznych (tzw. czynnik $s$, od angielskiego specific), które są ważne dla wykonania określonego typu zadania, np. wykonania złożonej operacji z zakresu arytmetyki czy czytania wymagającego artykułu. W oba zadania zaangażowana będzie inteligencja ogólna, jednocześnie, dla każdego z nich, będą angażowane inne zdolności specyficzne: matematyczne (arytmetyka) i werbalne (czytanie). Warto zauważyć, że sam Spearman nie precyzował, jaka jest liczba zdolności specyficznych.

Pomimo tego, że w historii badań nad inteligencją powstały również inne teorie, postulujące istnienie wielu równorzędnych rodzajów inteligencji (np. Gardner, 1993; Thurstone, 1938), to współcześnie niemal powszechnie wśród badaczy przyjmuje się, że struktura inteligencji człowieka jest hierarchiczna, z czynnikiem $g$ znajdującym się na szczycie tej hierarchii. Przekonujących danych na ten temat dostarczyły ogromne metaanalizy Carrolla (1993), w których analizował setki badań nad inteligencją. Okazało się, że model, który najbardziej pasuje do danych model, to taki, w którym na samym szczycie hierarchii wyróżnia się czynnik $g$ (zob. rysunek 1). Istnienie czynnika $g$ oznacza, że różne bardziej specyficzne zdolności są ze sobą dodatnio skorelowane. Poniżej czynnika $g$ znajduje się 8 stosunkowo szerokich zdolności, a na samym dole ok. 70 wąsko wyspecjalizowanych zdolności. Carroll poszczególne piętra hierarchii nazwał warstwami (stratum), poczynając od warstwy I - wąskich zdolności, poprzez szerokie zdolności w warstwie II, kończąc na czynniku $g \mathrm{w}$ warstwie III. Warto zwrócić uwagę, że w warstwie drugiej dwie pierwsze zdolności to inteligencja płynna (fuid; Gf) oraz inteligencja skrystalizowana (crystallized; Gc). Te dwa rodzaje zdolności zostały zaproponowane wcześniej przez Raymonda Cattella (1941, 1971) oraz jego studenta Johna Horna (1965). Inteligencja płynna odnosi się do zdolności do szybkiego i efektywnego przetwarzania informacji, rozumowania i dokonywania operacji na nieznanym materiale, rozwiązywania nowych problemów. Z kolei inteligencja skrystalizowana opisuje zdolność do uczenia się i zdobytą wiedzę człowieka. Carroll (1993) rozwinął teorię Cattella i Horna, dodając do warstwy II takie zdolności jak uczenie się i pamięć (Gy), zdolności wizualno-percepcyjne (Gv), zdolności słuchowe (Gu), wydobywanie z pamięci (Gr), ogólna szybkość przetwarzania informacji (Gs) oraz szybkość reakcji i szybkość decyzji (Gt). Koncepcje Carrolla oraz wcześniejsze, Cattella i Horna, były jeszcze dalej rozwijane, a obecnie ich zintegro- 
wana wersja występuje pod nazwą teorii inteligencji Cattella-Horna-Carrolla (McGrew, 2005).

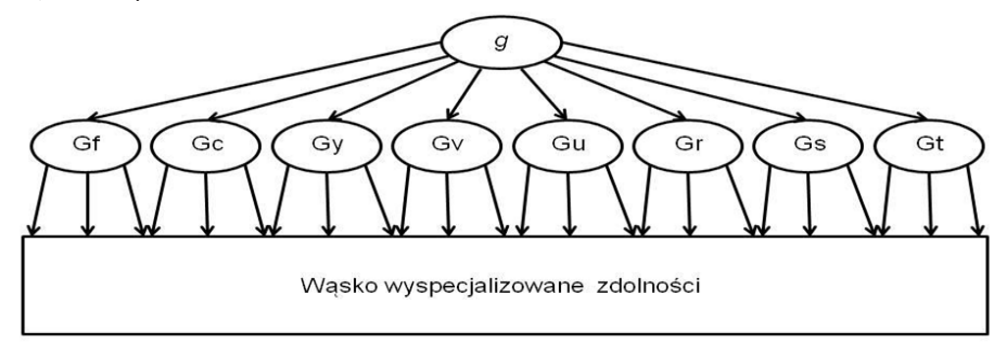

Rysunek 1. Hierarchiczna struktura inteligencji w ujeciu teorii Cattella-Horna-Carrolla.

O ile mogą istnieć w literaturze psychologicznej rozbieżności co do liczby i natury specyficznych zdolności, to większość badaczy zgadza się co do istnienia inteligencji ogólnej, czyli czynnika g, na szczycie hierarchii zdolności. Powstaje jednak pytanie czym jest ów tajemniczy czynnik g? Jaka jest istota inteligencji ogólnej? $\mathrm{Na}$ to pytanie udzielano różnorakich odpowiedzi na przestrzeni ostatniego stulecia. Najczęściej wskazywano jednak, że inteligencja ogólna ułatwia uczenie się na podstawie doświadczeń oraz adaptację do względnie nowych warunków środowiska (Sternberg, Detterman, 1986). Interesująca propozycję definicji inteligencji ogólnej przedstawiono również w artykule opublikowanym w 1994 r. w The Wall Street Journal pt. Mainstream science of intelligence, pod którym podpisało się 52 znanych badaczy inteligencji. W pierwszym akapicie pojawiła się następująca definicja:

Inteligencja to bardzo ogólna zdolność (capability), która między innymi obejmuje umiejętność (ability) rozumowania, planowania, rozwiązywania problemów, myślenia abstrakcyjnego, rozumienia złożonych idei, szybkiego uczenia się na podstawie doświadczeń. Nie dotyczy wyłącznie uczenia się z książek, wąskich umiejętności szkolnych czy poprawnego rozwiązywania testów. Stanowi raczej odzwierciedlenie szerszej i głębszej zdolności do rozumienia otoczenia - „chwytania”, „rozumienia” rzeczy lub „połapania się” w tym, co robić (Gottfredson, 1997, s. 13).

Zarówno w przytoczonej powyżej definicji, jak i w innych koncepcjach podkreśla się, że inteligencja nie jest zdolnością przydatną jedynie w kontekście szkolnym czy akademickim, ale ma szerokie zastosowanie w świecie. Inteligen- 
cja ogólna obejmuje łatwość adaptacji do nowych warunków, rozwiązywania problemów i rozumienia otaczającego nas świata. Wynika z tego, że jest to zdolność uniwersalna, która może ujawnić swoje znaczenie w niemal każdej dziedzinie życia. Od czasów Spearmana badacze starają się sprawdzić, na ile jest to prawda. Czy tajemniczy czynnik $g$ może mieć jakieś praktyczne zastosowanie? Czy ma jakiś związek z realnym życiem? Badania, które zostały opisane poniżej, wskazują na to, że inteligencja ogólna jest jedną ze zmiennych psychologicznych o dużym znaczeniu dla wielu sfer życia codziennego. Niektórzy postulują nawet, że nasze życie to jeden wielki test inteligencji.

\section{ŻYCIE JAKO TEST INTELIGENCJI}

Ponieważ inteligencja jest bardzo ogólną zdolnościa, wydawać by się mogło, że wiąże się tym samym z przetwarzaniem abstrakcyjnych informacji i ma małe praktyczne znaczenie. Liczne badania wskazują jednak, że tak nie jest. Okazuje się, że niewiele jest właściwości psychologicznych, które maja porównywalne do inteligencji znaczenie dla zjawisk z życia codziennego. Zwróćmy uwagę, że inteligencja to, jak wspomniano wcześniej, przede wszystkim zdolność do adaptacji i rozumienia otaczającego nas świata. Z samej definicji zatem inteligencja powinna pomagać w „połapaniu się” w codziennych problemach. Ponadto inteligencja odnosi się do szybkiego uczenia się, efektywnego rozumowania, myślenia abstrakcyjnego i rozwiązywania nowych problemów (Gottfredson, 1997). Są to uniwersalne zdolności, które mogą mieć zastosowanie praktycznie w każdej sferze życia. Jeżeli popatrzymy na zadania, które wykonujemy w życiu, łatwo zauważyć, że rzeczywiście wiele z nich wymaga zaangażowania procesów poznawczych właściwych inteligencji. $\mathrm{Na}$ tej podstawie amerykańska badaczka Linda Gottfredson (2004b) porównała życie do długiego testu inteligencji. Testu składającego się z wielu zadań, które każdy z nas codziennie wykonuje.

Gottfredson (2004a) zwraca uwagę, że zwykłe czynności dnia codziennego bywają złożone i wymagające poznawczo. Wystarczy przywołać takie czynności jak wypełnianie zeznań podatkowych, czytanie mapy w celu sprawdzenia jak dotrzeć z jednego miejsca do drugiego, czy zaplanowanie listy zakupów na cały tydzień, aby uzmysłowić sobie złożoność naszych codziennych obowiązków. Gottfredson (2004b) pokazuje, że nawet tak z pozoru zwyczajna czynność jak sprawdzenie rozkładu jazdy na przystanku autobusowym może być wyzwaniem intelektualnym. Autorka podaje przykład, w którym pytano ludzi, jak długo trzeba czekać na autobus jadący z punktu A do punktu B w sobotę, 
kiedy właśnie przegapiło się autobus o godzinie 14.35. Informację należało podać na podstawie rozkładu jazdy podobnego do tego, który można spotkać na każdym przystanku autobusowym. Ogromna większość osób w tej sytuacji błędnie wskazywało następna godzinę odjazdu autobusu. Okazało się bowiem, że godziny odjazdów dotyczą całego tygodnia z wyjątkiem sobót. Prawidłowa odpowiedź wiązała się z dostrzeżeniem zdania napisanego drobnym drukiem poniżej rozkładu jazdy, mówiącego o tym, że w soboty autobusy odjeżdżają co godzinę. W tego typu zadaniu należało więc odseparować informacje istotne od nieważnych, a także powstrzymać się od pierwszej, narzucającej się reakcji. Tego typu procesy odnoszą się do podstawowych funkcji poznawczych, takich jak uwaga czy kontrola poznawcza, mocno powiązanych z inteligencja (Chuderski, Taraday, Nęcka, Smoleń, 2012).

Podobnych przykładów można by zapewne podać wiele. Wśród nich można wymienić takie sytuacje jak przetwarzanie dokumentów prawnych, np. umowy o świadczenie usług telekomunikacyjnych, dzielenie rachunku w restauracji pomiędzy kilka osób, zakładanie konta w banku czy wypełnienie odpowiednich druków w urzędzie. Do tego możemy dodać szybki rozwój technologiczny, który wymusza na ludziach ciagłe uczenie się i dostosowanie do nowinek technicznych. Wszystkie te sytuacje wiążą się z mniejszym lub większym zaangażowaniem zasobów intelektualnych.

Często nie uświadamiamy sobie nawet, że nasze aktywności i role społeczne podobne są do złożonej poznawczo pracy. Na przykład bycie rodzicem, oprócz wysiłku fizycznego, wymaga planowania, koordynowania, doradzania, nauczania, zdolności negocjowania, wydawania klarownych instrukcji itp. Podobne aktywności są wymagane w pracach o wysokim statusie społecznym i wysokiej złożoności poznawczej (Gottfredson, 2004a, 2004b). Wszystkie te przykłady dobrze ilustrują zatem porównanie życia do testu inteligencji. Dotychczasowe badania nad inteligencją i jej znaczeniem praktycznym skupiały się szczególnie na trzech obszarach życia: pracy, szkole i zdrowiu.

\section{INTELIGENCJA A SZKOŁA}

Od samego początku badań nad inteligencją osiagnięcia szkolne były ważnym kryterium trafności zadań mierzących inteligencję. Jeden z pierwszych współczesnych badaczy inteligencji, Francis Galton (1869), a później także jego uczeń, James McKeen Cattell (1890), stwierdzili, że aby sprawdzić, czy określony pomiar zdolności jest poprawny (trafny), należy go porównać z jakimś niezależnym kryterium. Obaj badacze uznali zgodnie, że jednym z naj- 
lepszych kryteriów dla zadań mierzących inteligencję może być poziom osiągnięć szkolnych lub akademickich (Wissler, 1901). Co ciekawe, pierwszy test inteligencji również powstał w kontekście potrzeb edukacyjnych. Alfred Binet na zlecenie rządu francuskiego podją się stworzenia narzędzia, które pozwoliłoby na diagnozę uczniów charakteryzującymi się trudnościami intelektualnymi w szkole (Binet, 1905). Podobnie teoria inteligencji ogólnej (czynnika g) Spearmana (1904) została zaproponowana również na podstawie wyników zadań szkolnych rozwiązywanych przez uczniów.

Badania nad inteligencją i osiagnięciami szkolnymi są prowadzone od ponad 100 lat. Najczęściej sprowadzają się do badania związku pomiędzy wynikami $\mathrm{w}$ testach inteligencji a ocenami szkolnymi lub ewentualnie poziomem wykonania różnych zadań związanych z przedmiotami szkolnymi. Dane wskazują na dodatnią korelację wahająca się od umiarkowanej do silnej, tj. od 0,40 do 0,70 (Brody, 1992; Jensen, 1998; Mackintosh, 2011; Neisser i in., 1996; Sternberg, Grigorenko, Bundy, 2001). Ważna obserwacja badaczy wiąże się z tym, że korelacja pomiędzy inteligencją a sukcesem szkolnym jest silniejsza na wcześniejszym etapie edukacji, a słabsza na późniejszym (Mackintosh, 2011). Wiąże się to zapewne $z$ faktem, że na dalszych etapach, takich jak szkoła średnia czy uniwersytet, następuje coraz większa selekcja osób uczących się, opierająca się zazwyczaj na podstawie ich wcześniejszych osiagnięć. Selekcja ta sprawia, że mamy do czynienia z mniejszym zróżnicowaniem wśród uczniów i studentów w zakresie ich zdolności. Innymi słowy, aby dostać się na studia, trzeba wykazać się pewnym poziomem inteligencji, zazwyczaj ponadprzeciętnym. Tym samym, na uniwersytecie można spotkać osoby o podobnie wysokim poziomie IQ, czego konsekwencja jest fakt, że sama inteligencja ma mniejsze znaczenie dla osiagnięć akademickich, natomiast do głosu dochodzić może osobowość (np. sumienność) studentów.

Powyższe wyniki wydają się dość jednoznacznie wskazywać na relatywnie silny związek pomiędzy inteligencją a osiagnięciami szkolnymi i akademickimi. Jednak niektórzy badacze zwracają uwagę na pewne problemy związane z jasną interpretacją tych rezultatów. Po pierwsze, warto zauważyć, że część powszechnie używanych testów inteligencji, takich jak test Wechslera czy test Stanford-Binet, zawiera zadania podobne do tych używanych w szkole, np. zadania arytmetyczne. Wysoka korelacja między tymi testami a ocenami szkolnymi nie wydaje się zatem niczym zaskakującym, ponieważ w obu przypadkach, przynajmniej częściowo, materiał pokrywa się (Evans, Waites, 1981). O ile trudno polemizować z tego typu argumentem, to warto zauważyć, że inne testy inteligencji, 
które nie zawierają zadań zbliżonych do szkolnych (np. test Ravena), również korelują z osiagnięciami szkolnymi.

Inny zarzut wobec badań nad związkiem inteligencja-szkoła dotyczy kierunku wpływu tych dwóch zmiennych. Czy jest tak, że inteligencja wpływa na osiagnięcia szkolne, czy też jest możliwy odwrotny kierunek zależności: szkoła stymuluje rozwój inteligencji? Istnieje wiele argumentów za tą drugą możliwością. Ceci (1991; Ceci, Williams, 1997) wskazuje na unikatowe dane na temat inteligencji uczniów, pochodzące z czegoś, co można by nazwać eksperymentem naturalnym, w którym dzieci były pozbawione szkoły. W każdym takim przypadku odnotowywano spadek poziomu inteligencji. Przykładem moga być uczniowie, którzy mieli przerwy w uczęszczaniu do szkoły (np. z powodu choroby), efekt wakacji (spadek IQ po przerwie wakacyjnej), czy też późniejsze rozpoczęcie edukacji (odnotowuje się niższy poziom IQ w stosunku do rówieśników). Inne dane pochodzą z czasów zamknięcia szkół w czasie drugiej wojny światowej (DeGroot, 1951) lub sytuacji, w której uczniowie zaczynaja wcześniej edukację (zazwyczaj szybko doganiają starszych kolegów i koleżanki). Najnowsza metaanaliza wielu pojedynczych badań wykazała, że każdy kolejny rok edukacji może zwiększyć poziom inteligencji od 1 aż do 5 punktów IQ (Ritchie, Tucker-Drob, 2018). Wszystkie te dane sugerują, że z pewnościa szkoła może stymulować rozwój inteligencji.

Pomimo wspomnianych uwag krytycznych oraz badań nad wpływem szkoły na inteligencję, istnieją również mocne argumenty za tym, że to poziom inteligencji determinuje osiagnięcia szkolne. Takie koncepcje odwołują się do danych podłużnych, w których bada się inteligencję i funkcjonowanie w szkole przez wiele lat. Jedno z najczęściej przytaczanych badań w tym kontekście analizowało dane $z$ okresu pięciu lat na grupie ponad 70000 dzieci angielskich (Deary, Strand, Smith, Fernandes, 2007). Wykazano, że poziom inteligencji mierzony w wieku lat 11 był niezwykle wysoko skorelowany $(0,81) \mathrm{z}$ wynikiem ogólnokrajowych egzaminów z 25 przedmiotów w wieku lat 16.

W tym miejscu warto również przytoczyć unikatowe polskie dane pochodzące z projektu znanego jako Warsaw Study (zob. Firkowska-Mankiewicz, 2002). Było to badanie podłużne zapoczątkowane w 1974 roku, mające na celu sprawdzenie związków między poziomem inteligencji a zmiennymi socjodemograficznymi, zdrowotnymi i szeroko pojętym sukcesem życiowym, w tym szkolnym (Firkowska $i$ in., 1978). W pierwszej fazie przebadano cały rocznik 11-letnich dzieci urodzonych w roku 1963 mieszkających w Warszawie. Próba ta obejmowała ponad 14000 dzieci. Badania były kontynuowane przez kilka kolejnych dekad w pięciu falach badań. Ich wyniki były zgodne z wyżej 
przytoczonymi danymi (Deary i in., 2007). Okazało się, że IQ w wieku lat 11 przewidywało sukces edukacyjny 20 lat później. Osoby o wysokim poziomie inteligencji jako dzieci znacznie częściej uzyskiwały wyższe wykształcenie, a po studiach podejmowały prace wymagające wysokich kwalifikacji (Firkowska-Mankiewicz, 2002).

Zdaniem badaczy, tego typu wyniki sugeruja przyczynowy kierunek zależności od inteligencji do osiagnięć szkolnych (Deary i in., 2007). Biorąc pod uwagę różne czynniki, trudno jednoznacznie stwierdzić, jak przebiega kierunek przyczynowo-skutkowy relacji inteligencji i szkoły. Można wyobrazić sobie sytuację, że jest to wzajemne oddziaływanie. Być może istnieją również zmienne pośredniczące, które mogą wyjaśnić tę zależność, na przykład aspekt społeczny szkoły.

\section{INTELIGENCJA W PRACY}

Pomiar inteligencji w kontekście pracy był stosowany od czasu stworzenia pierwszych testów inteligencji. Już na początku XX w. testy inteligencji były używane na szeroką skalę w rekrutacji do pracy (zob. Mackintosh, 2011). W czasie pierwszej wojny światowej stworzono pierwsze testy do zastosowania grupowego, za pomoca których można było jednocześnie badać wiele osób. Stosowano je powszechnie w rekrutacji na wyższe stanowiska w armii amerykańskiej. Tak duże zainteresowanie testowaniem inteligencji w pracy zaowocowało licznymi badaniami nad użytecznością tej metody w selekcji kandydatów do pracy. Badacze starali się syntetyzować wyniki tych badań za pomocą metaanaliz, czyli podsumowania wielu (czasem nawet kilku tysięcy) pojedynczych wyników empirycznych.

Jednego z największych przeglądów badań nad inteligencją i pracą dokonali Hunter i Schmidt (1998), którzy przeprowadzili metaanalizę badań prowadzonych przez 85 lat, opisanych w kilku tysiącach publikacji. Autorzy przeanalizowali 19 sposobów dokonywania selekcji kandydatów do pracy, takich jak m.in. testy inteligencji, próbne wykonanie pracy, testy uczciwości, testy sumienności, rozmowy kwalifikacyjne, referencje, doświadczenie zawodowe, liczba lat edukacji, zainteresowania, a nawet analiza grafologiczna, która była stosowana w niektórych krajach i firmach. Następnie sprawdzili, jaka jest korelacja pomiędzy daną metodą selekcji kandydatów a późniejszą jakością ich pracy. Okazało się, że najsilniejszą korelację, na poziomie 0,54 , uzyskano w przypadku próbnego sprawdzenia pracy. Ta metoda polegała na tym, że dany kandydat przez pewien czas wykonywał pracę, o którą się starał. Jednak- 
że, jak wskazują badacze, taka procedura jest dość czasochłonna i kosztowna. Wydaje się zatem mało przydatna w sytuacji, w której trzeba wyselekcjonować kilku kandydatów z dużej grupy osób ubiegających się o dane stanowisko. Inną metodą wysoko korelująca $(0,51)$ z jakościa pracy okazała się ustrukturyzowana rozmowa kwalifikacyjna. Co ciekawe, podobną skuteczność miało zastosowanie w selekcji testu inteligencji, który korelował na tym samym poziomie $(0,51)$ z efektywnością w pracy, co ustrukturyzowana rozmowa kwalifikacyjna. Wszystkie pozostałe metody charakteryzowały się znacznie mniejszą korelacją. Przykładowo sprawdzenie referencji to korelacja jedynie na poziomie 0,26, natomiast doświadczenie zawodowe korelowało 0,18 z efektywnością w pracy. Niektóre z metod okazały się w ogóle nie związane z jakością pracy, np. analiza grafologiczna, co oznacza, że stosowanie jej nie przynosi żadnych informacji o późniejszej pracy kandydata.

Wyniki badań Huntera i Schmidta (1998) wskazują zatem, że test inteligencji, w porównaniu do innych metod, jest jedną z najlepszych metod selekcji pracowników. Czy korelacja ok. 0,50 to dużo? Otóż taka wielkość współczynnika korelacji oznacza, że istnieje ok. 25\% wspólnej zmienności (współwystępowania) pomiędzy zróżnicowaniem w zakresie wykonania testów inteligencji a zróżnicowaniem między ludźmi w zakresie jakości wykonania ich pracy. Jest to wartość stosunkowo duża, biorąc pod uwagę pojedynczą zmienną psychologiczną (Deary, 2012). Dodatkowo Hunter i Schmidt (1998) zwracają uwagę, że test inteligencji jest metodą stosunkowo szybką i łatwą do zastosowania nawet na dużej grupie ludzi, co wzmacnia jeszcze jego wartość jako narzędzia służącego selekcji kandydatów do pracy.

Warto jednak zwrócić uwagę, że o ile w ogólnym zastosowaniu testy inteligencji wydają się być efektywnym sposobem selekcji kandydatów do pracy, to jednocześnie znaczenie inteligencji może być różne w zależności od rodzaju zawodu. Wyniki innych metaanaliz brały pod uwagę stopień złożoności określonych profesji, pokazując, że korelacja inteligencji z efektywnością w mniej złożonych pracach wynosi ok 0,36 , natomiast w średnio i wysoko złożonych zawodach ta korelacja wynosi odpowiednio 0,53 i 0,74 (Salgado i in., 2003). Jak zauważają niektórzy badacze, być może istnieja pewne progi poziomu IQ, które są konieczne, aby osiagnąć sukces w określonych zawodach (Jensen, 1980). Przykładowo, zapewne niewielu jest lekarzy czy prawników charakteryzujących się inteligencją poniżej średniej. To przypuszczenie jest częściowo potwierdzone faktem istnienia różnic między grupami zawodowymi w zakresie średniego poziomu IQ. Jak przedstawiono w tabeli 1, wśród prac o najwyższym poziomie inteligencji (mierzonej Wonderlic Personnel Test, Wonderlic, Inc., 1999) znajduja 
się takie zawody jak prawnik/prawniczka i inżynier/inżynierka, gdzie poziom IQ waha się pomiędzy 108 a 128, natomiast stosunkowo niski poziom IQ (80-100) wiazże się z wykonywaniem takich prac jak pakowanie produktów czy stróżowanie/ochrona (Gottfredson, 2002, 2003, 2004a, 2004b).

Tabela 1. Praykladowe zawody i poziom inteligencij z nimi zwiazany (za: Gottfredson, 2004b)

\begin{tabular}{lcc}
\hline \multicolumn{1}{c}{ Zawód } & Zakres IQ & $\begin{array}{c}\text { Odsetek osób poniżej } \\
\text { tego poziomu (centyl) }\end{array}$ \\
\hline $\begin{array}{l}\text { Prawnik/prawniczka } \\
\text { Inżynier/inżynierka }\end{array}$ & $108-128$ & $70-97$ \\
\hline $\begin{array}{l}\text { Nauczyciel/nauczycielka } \\
\text { Programista/programistka }\end{array}$ & $100-120$ & $50-90$ \\
\hline $\begin{array}{l}\text { Sekretarz/sekretarka } \\
\text { Technik/techniczka laboratoryjny(a) }\end{array}$ & $96-116$ & $40-85$ \\
\hline $\begin{array}{l}\text { Inkasent/inkasentka } \\
\text { Kasjer/kasjerka }\end{array}$ & $91-110$ & $27-75$ \\
\hline $\begin{array}{l}\text { Spawacz/spawaczka } \\
\text { Ochroniarz/ochroniarka }\end{array}$ & $85-105$ & $15-63$ \\
\hline $\begin{array}{l}\text { Osoba pakująca } \\
\text { Stróż/stróżka }\end{array}$ & $80-100$ & $10-50$ \\
\hline
\end{tabular}

Inne dane wskazują, że hierarchia różnych zawodów nie jest przypadkowa i może zależeć od ich złożoności. W przypadku ogromnej większości prac pracownicy mogą wykonywać swoje zadania i obowiązki lepiej lub gorzej, mniej lub bardziej efektywnie. W pewnym stopniu przypomina to zadania z testu inteligencji, w którym istnieja pewne obiektywne kryteria czy prawidłowe rozwiązania, a osoba badana testem inteligencji może wypaść lepiej lub gorzej (Gottfredson, 2003). Analiza różnych aspektów pracy, takich jak przetwarzanie informacji, podejmowanie decyzji, zdobywanie nowej wiedzy, powtarzalność czy potrzeba (lub brak) nadzoru, wykazała istnienie nadrzędnego czynnika, który określić można jako złożoność pracy. Wysoka złożoność pracy wiąże się z umiejętnością przetwarzania informacji z wielu źródeł, rozumowaniem na podstawie dostępnych danych, jasnym komunikowaniem decyzji innym, 
zdolnością do krytycznego myślenia, a także samodzielnym podejmowaniem decyzji. Mniej złożone prace charakteryzują się dużą powtarzalnością wykonywanych czynności, wysiłkiem fizycznym, wysokim stopniem ustrukturyzowania oraz wykonywaniem zadań pod nadzorem. Co ciekawe, stopień złożoności różnych profesji koresponduje ze średnim poziomem inteligencji obserwowanym w danej grupie zawodowej. Na przykład zawód lekarza wiąże się zarówno z ponadprzeciętnym poziomem IQ, jak i wysokim stopniem złożoności.

Powyższe wyniki wskazują na spore znaczenie inteligencji dla wykonywania określonych zawodów. Niektórzy próbują wyjaśnić te zależności, odwołując się do innych zmiennych, takich jak na przykład status socjoekonomiczny rodziców lub pośrednicząca rola wykształcenia. Innymi słowy, pomoc i wsparcie rodziców mogą ułatwiać dostęp do określonej grupy zawodowej. Z drugiej strony, aby móc wykonywać prestiżowy i zarazem bardziej złożony zawód, trzeba mieć odpowiednie wykształcenie. Analizy uwzględniające znaczenie tych zmiennych (statusu socjoekonomicznego i poziomu wykształcenia) wykazały jednak, że po wyeliminowaniu (kontroli) ich działania poziom inteligencji ciagle wykazywał znaczący związek z sukcesem w pracy i przynależnością do określonej grupy zawodowej (Strenze, 2007).

\section{INTELIGENCJA A ZDROWIE I DŁUGOŚĆ ŻYCIA}

Najdłuższa historia badań nad praktycznym znaczeniem inteligencji wiąże się ze szkoła i pracą. Niemniej jednak, w ostatnich dekadach spektakularne wyniki uzyskano w zakresie zdrowia, sferze życia, której na pierwszy rzut oka nie łączylibyśmy z poziomem zdolności intelektualnych. Jednakże, według przytoczonej wcześniej definicji, inteligencja nie jest jedynie wąską zdolnością przydającą się w kontekście szkolnym, ale odzwierciedla szeroką zdolność do adaptacji do środowiska oraz „połapania” się w świecie (Gottfredson, 1997). Wydaje się zatem, że jakość zdrowia i długość życia moga być podstawowym wyznacznikiem zdolności przystosowania się do warunków środowiskowych.

Badania wskazuja że inteligencja rzeczywiście sprzyja zdrowiu i długowieczności. Jedno z pierwszych doniesień w tym zakresie zaprezentowali O’Toole i Stankov (1992), którzy przeanalizowali dane podłużne pochodzace z populacji australijskich weteranów wojny w Wietnamie. Wojskowi byli badani testem inteligencji przy wstępowaniu do armii. Na próbie ponad 2300 mężczyzn wykazano, że kiedy kontrolowano inne zmienne (np. demograficzne), każdy punkt IQ zmniejszał szansę na śmierć poza frontem przed 40. rokiem życia o 1\%. W tej grupie najczęstsza przyczyną zgonów były wypadki samochodowe. 
Najbardziej spektakularnych wyników na temat inteligencji w kontekście zdrowia dostarczyły badania współczesnego szkockiego badacza Iana Deary'ego. Autor przeanalizował dane pochodzące z 1932 roku zebrane w Szkocji na niemal całej populacji jednego rocznika. To badanie znane jest jako Scottish Mental Survey 1932 (SMS1932) i zostało przeprowadzone na zlecenie rządu szkockiego. W dniu 1 czerwca 1932 r. został przeprowadzony test inteligencji (Moray House Test) wśród wszystkich 11-letnich uczniów obecnych tego dnia w szkole $(N=89498)$, co stanowiło ok 95\% całego rocznika 1921. Jak do tej pory sa to jedyne dane na temat inteligencji zebrane prawie z całej populacji osób urodzonych w danym roku (Gottfredson, Deary, 2004). Deary i współpracownicy (zob. np. Deary, Whalley, Starr, 2009) dotarli do tych, nieco zapomnianych, danych po wielu latach, słusznie czując ich ogromny potencjał. Okazało się, że można było prześledzić losy bardzo wielu osób badanych SMS1932, a w przypadku osób żyjacych ponownie ich przebadać. W ten sposób otrzymano unikatowe dane na temat tego, jak inteligencja mierzona w wieku lat 11 przewiduje dalsze wydarzenia z życia ludzi, nawet 80 lat później. Na podstawie tych danych powstało tysiące publikacji, a na Uniwersytecie w Edynburgu otwarto nawet centrum zajmujące się poznawczym podłożem starzenia się i chorób (Centre for Cognitive Ageing and Cognitive Epidemiology). Poniżej przedstawione zostaną wybrane wyniki analiza danych SMS1932.

W jednym z badań Whalley i Deary (2001) próbowali zidentyfikować osoby z okolic Aberdeen. Udało im się odnaleźć informacje o 2792 dzieciach badanych w 1932 r. Następnie badacze starali się dotrzeć do informacji na temat zdrowia oraz rejestru zgonów w Szkocji. Poszukiwania były szczególnie trudne w przypadku kobiet, które często zmieniały nazwiska po wyjściu za mąż. Ostatecznie odnaleziono informacje na temat 2230 dzieci (ok. 80\%) dzieci z Aberdeen, które uczestniczyły w testowaniu inteligencji SMS1932. Z tej grupy 1084 osoby nie żyły, 1101 żyło, a 45 osób wyprowadziło się ze Szkocji. W pierwszym kroku, badacze dokonali analizy tego, jak inteligencja w wieku lat 11 związana była z szansą przeżycia do 76 . roku życia. Wiek 76 lat był brany pod uwage $z$ tego powodu, że badacze dysponowali w czasie analiz rejestrem zgonów z roku 1997. Ogólnie mówiąc, osoby z niższym IQ w wieku lat 11 miały istotnie mniejszą szansę dożyć wieku lat 76. Średnio, osoby, które znajdowały się jedno odchylenie standardowe poniżej średniej w teście inteligencji (czyli 15 punktów IQ), w porównaniu do osób o wyższym IQ, miały 21\% szans mniej na przeżycie do 76. roku życia. Badacze zwracają uwagę, że efekt inteligencji okazał się silniejszy wśród kobiet, ponieważ wielu mężczyzn o relatywnie wysokim IQ zginęło w czasie drugiej wojny światowej. W dalszych 
analizach danych z Aberdeen (Deary, Whalley, Starr, 2003) wykazano również, że jedno odchylenie standardowe poniżej średniej IQ wiązało się z większą szansą śmierci z powodu raka zarówno wśród mężczyzn (o 27\%), jak i wśród kobiet (o 40\%). Inne badania wykazały również, że wśród osób z niższym IQ istnieje większe ryzyko zapadnięcia na i zgonu z powodu wielu chorób, takich jak choroby układu sercowo-naczyniowego, nowotwory czy choroby związane z układem oddechowym (Batty, Deary, 2004; Batty, Deary, Gottfredson, 2007; Batty, Deary, MacIntyre, 2007; Batty, Shipley, Gale, Mortensen, Deary, 2008; Deary, Whiteman, Starr, Whalley, Fox, 2004). Okazuje się również, że poziom inteligencji mierzony we wczesnym okresie życia koreluje z mniejszym nasileniem objawów fizycznych starzenia się (Gale, Ritchie, Starr, Deary, 2020; Okely, Deary, 2020). Podsumowując badania nad SMS1932, Deary (2008) zauważa, że poziom inteligencji przewiduje śmiertelność w wyższym stopniu niż wskaźnik BMI (body mass index), ogólny poziom cholesterolu, ciśnienie krwi czy poziom glukozy we krwi, a w podobnym stopniu co palenie papierosów.

W ostatnich dekadach prowadzone były na szeroką skalę również inne badania nad inteligencją i zdrowiem, np. w kontekście przewlekłych chorób. Jak zauważa Gottfredson (2004b), sytuacja nagłej diagnozy choroby, która będzie towarzyszyła człowiekowi do końca życia, znów „pasuje” do definicji inteligencji jako zdolności do adaptacji do nowych warunków środowiska. Człowiek, który dowiaduje się o chorobie, musi nagle poradzić sobie z natłokiem informacji o tym, co ma robić, jakie przejść procedury, jak działa system opieki zdrowotnej w tym zakresie, jak powinien dostosować swoje życie do nowej sytuacji. Na przykład diabetyk jest zmuszony do zmiany swoich nawyków żywieniowych, zachowań, monitorowania poziomu cukru, większej uważności na odczucia cielesne, takie jak spadek energii itp. Dodatkowo w większości krajów system opieki zdrowotnej jest skomplikowany i wymaga treningu, aby przeprowadzać sprawnie badania i diagnozy. Wydaje się, że tego typu sytuacja jest bardzo złożona i wymagająca poznawczo, podobna do trudnego testu inteligencji. Jako ilustrację złożoności poznawczej można przywołać badania, w których pytano osoby z przewlekła chorobą o podstawowe fakty dotyczace ich choroby. Ogromny odsetek diabetyków nie potrafił trafnie określić, co oznaczają takie sygnały cielesne jak nagłe uczucie zmęczenia, głodu czy pocenia się (Williams, Baker, Parker, Nurss, 1998). Ograniczanie negatywnych skutków przewlekłej choroby to również codzienny wysiłek i nieustanne monitorowanie własnego zachowania. Codzienne kontrolowanie swoich działań łączy się jednak nie tylko z przewlekłą chorobą, ale również np. z unikaniem 
wypadków i ryzyka, dla których to zachowań inteligencja również ma znaczenie (Gottfredson, 2004a; 2018).

Pytanie, jakie rodzi się w kontekście przytoczonych badań, dotyczy przyczyny zwiazku inteligencji z lepszym zdrowiem. Jeden z pomysłów wyjaśnienia tej zależności wiąże się z odwołaniem do trzeciej zmiennej, pośredniczącej, jaką może być status socjoekonomiczny. Inteligencja wiąże się z wyższym poziomem wykształcenia, co może przekładać się na bardziej prestiżową pracę, a tym samym wyższe zarobki. Większe zasoby materialne pozwalają na lepsze troszczenie się o własne zdrowie. Rzeczywiście, status socjoekonomiczny wyjaśnia część zależności pomiędzy inteligencją a zdrowiem, jednakże większość analiz wykazuje, że inteligencja ma istotne znaczenie dla zdrowia i długości życia, niezależnie od zmiennych demograficznych i ekonomicznych (Gottfredson, Deary, 2004). Dodatkowo dane amerykańskie wskazują również na to, że zapewnienie bezpłatnego dostępu do opieki medycznej nie zmniejsza nierówności społecznych w zakresie zdrowia (Gottfredson, 2004b). Można oczywiście pomyśleć, że jest to głębszy problem, związany być może z pewnymi nawykami (mniej lub bardziej prozdrowotnymi) obecnymi wśród przedstawicieli różnych grup społecznych.

Innych prób wyjaśnienia roli inteligencji dla zdrowia doszukiwano się w tym, że zarówno na poziom inteligencji związanej z mózgiem, jak i na ogólne zdrowie mogły wpływać te same czynniki biologiczne, związane z doświadczeniami w okresie prenatalnym, różnymi wypadkami, przebytymi chorobami $\mathrm{i}$ innymi wydarzeniami oddziałującymi na organizm człowieka (Gottfredson, Deary, 2004). Wreszcie wysuwano przypuszczenie, że wynik testu inteligencji może być wskaźnikiem ogólnie sprawnego systemu, dobrze działającego ciała (Gottfredson, Deary, 2004). Te interpretacje wydają się interesujące, jednakże ich potwierdzenie wymaga dalszych pogłębionych badań (Deary, 2008).

\section{PODSUMOWANIE}

Liczne badania nad praktycznym znaczeniem inteligencji wykazuja jednoznacznie, że poziom IQ koreluje silnie z wieloma aspektami naszego codziennego życia, takimi jak osiagnięcia szkolne, efektywność w pracy, a nawet jakość zdrowia i długość życia. Badacze zwracają uwagę na to, że codzienne życie wymaga złożonych operacji umysłowych i nawet z pozoru zwyczajne zachowania moga stawiać przed nami wyzwania intelektualne. Nasza aktywność każdego dnia wymaga zatem myślenia, uczenia się, rozumowania, pamiętania i przetwarzania złożonych informacji. Ponieważ inteligencja to ogólna sprawność w zakresie 
używania procesów poznawczych, ale też zdolność do adaptacji do nowych warunków środowiska, jej duże znaczenie dla czynności dnia codziennego wydaje się zrozumiałe.

\section{BIBLIOGRAFIA}

Batty, G. D., Deary, I. J. (2004). Early life intelligence and adult health. British Medical Journal, 329(7466), 585-586. https://doi.org/10.1136/bmj.329.7466.585

Batty, G. D., Deary, I. J., Gottfredson, L. S. (2007). Premorbid (early life) IQ and later mortality risk: Systematic review. Annals of Epidemiology, 17(4), 278-288. https:// doi.org/10.1016/j.annepidem.2006.07.010

Batty, G. D., Deary, I. J., MacIntyre, S. (2007). Childhood IQ in relation to risk factors for premature mortality in middle-aged persons: The Aberdeen Children of the 1950s study. Journal of Epidemiology and Community Health, 61(3), 241-247. https:// doi.org/10.1136/jech.2006.048215

Batty, G. D., Shipley, M. J., Gale, C. R., Mortensen, L. H., Deary, I. J. (2008). Does IQ predict total and cardiovascular disease mortality as strongly as other risk factors? Comparison of effect estimates using the Vietnam Experience Study. Heart, 94(12), 1541-1544. https:// doi.org/10.1136/hrt.2008.149567

Binet, A. (1905). New methods for the diagnosis of the intellectual level of subnormals. L'Année Psychologique, 12, 191-244. https://doi.org/10.1037/11069-002

Brody, N. (1992). Intelligence. Nowy Jork: Academic.

Carroll, J. B. (1993). Human cognitive abilities: A survey of factor-analytic studies. Cambridge: Cambridge University Press.

Cattell, J. McK. (1890). Mental tests and measurements. Mind, 15(59), 373-381. https://doi.org/10.1093/mind/os-XV.59.373

Cattell, R. B. (1941). Some theoretical issues in adult intelligence testing. Psychological Bulletin, 38(6), 592.

Cattell, R. B. (1971). Abilities: Their structure, growth, and action. Boston: Houghton Mifflin.

Chuderski, A., Taraday, M., Nęcka, E., Smoleń, T. (2012). Storage capacity explains fluid intelligence but executive control does not. Intelligence, 40(3), 278-295. https://doi.org/10.1016/j.intell.2012.02.010

Ceci, S. J. (1991). How much does schooling influence general intelligence and its cognitive components? A reassessment of the evidence. Developmental Psychology, 27(5), 703-722. https://doi.org/10.1037/0012-1649.27.5.703

Ceci, S. J., Williams, W. M. (1997). Schooling, intelligence, and income. American Psychologist, 52(10), 1051-1058. https://doi.org/10.1037/0003-066X.52.10.1051 
Deary, I. J. (2008). Why do intelligent people live longer? Nature, 456(7219), 175-176. https:// doi.org/10.1038/456175a

Deary, I. J. (2012). Inteligencja. Gdańsk: Gdańskie Wydawnictwo Psychologiczne.

Deary, I. J., Strand, S., Smith, P., Fernandes, C. (2007). Intelligence and educational achievement. Intelligence, 35(1), 13-21. https://doi.org/10.1016/j.intell.2006.02.001

Deary, I. J., Whalley, L. J., Starr, J. M. (2003). IQ at age 11 and longevity: Results from a follow up of the Scottish Mental Survey 1932. W: C. E. Finch, J.-M. Robine, Y. Christen (red.), Brain and longevity: Perspectives in longevity (s. 153-164). Berlin: Springer. https:/ / doi.org/10.1007/978-3-642-59356-7_10

Deary, I. J., Whalley, L. J., Starr, J. M. (2009). A lifetime of intelligence. Waszyngton: American Psychological Association.

Deary, I. J., Whiteman, M. C., Starr, J. M., Whalley, L. J., Fox, H. C. (2004). The impact of childhood intelligence on later life: Following up the Scottish Mental Surveys of 1932 and 1947. Journal of Personality and Social Psychology, 86(1), 130-147. https:// doi.org/10.1037/0022-3514.86.1.130

DeGroot, A. D. (1951). War and the intelligence of youth. The Journal of Abnormal and Social Psychology, 46(4), 596-597. https://doi.org/10.1037/h0057014

Evans, B., Waites, B. (1981). IQ and mental testing: An unnatural science and its social history. Atlantic Highlands: Humanities Press.

Firkowska, A., Ostrowska, A., Sokołowska, M., Stein, Z., Susser, M., Wald, I. (1978). Cognitive development and social policy. Science, 200(4348), 1357-1362. https:/ / doi.org/10.1126/science.663616

Firkowska-Mankiewicz, A. (2002). IQ jako prognostyk kariery życiowej. Studia Socjologiczne, 2(165), 15-37.

Gale, C., Ritchie, S. J., Starr, J. M., Deary, I. J. (2020). Physical frailty and decline in general and specific cognitive abilities: The Lothian Birth Cohort 1936. Journal of Epidemiology and Community Health, 74(2), 108-113. https://doi.org/10.1136/ jech-2019-213280

Galton, F. (1869). Hereditary genius: An inquiry into its laws and consequences. Londyn: Macmillan.

Gardner, H. (1993). Multiple intelligences: The theory in practice. Nowy Jork: Basic Books.

Gottfredson, L. S. (1997). Mainstream science on intelligence: An editorial with 52 signatories, history, and bibliography. Intelligence, 24(1), 13-23. https://doi. org/10.1016/S0160-2896(97)90011-8

Gottfredson, L. S. (2002). g: Highly general and highly practical. W: R. J. Sternberg, E. L. Grigorenko (red.), The general factor of intelligence: How general is it? (s. 331-380). Mahwah: Erlbaum. 
Gottfredson, L. S. (2003). g, jobs, and life. W: H. Nyborg (red.), The scientific study of general intelligence: Tribute to Arthur R. Jensen (s. 293-342). Nowy Jork: Pergamon.

Gottfredson, L. S. (2004a). Intelligence: Is it the epidemiologists’ elusive „fundamental cause" of social class inequalities in health? Journal of Personality and Social Psychology, 86(1), 174-199. https://doi.org/10.1037/0022-3514.86.1.174

Gottfredson, L. S. (2004b). Life, death, and intelligence. Journal of Cognitive Education and Psychology, 4(1), 23-46. https://doi.org/10.1891/194589504787382839

Gottfredson, L. S. (2018). $g$ theory: How recurring variation in human intelligence and the complexity of everyday tasks create social structure and the democratic dilemma. W: R. J. Sternberg (red.), The nature of human intelligence (s. 130-151). Nowy Jork: Cambridge University Press.

Gottfredson, L. S., Deary, I. J. (2004). Intelligence predicts health and longevity, but why? Current Directions in Psychological Science, 13(1), 1-4. https://doi.org/10.1111/ j.0963-7214.2004.01301001.x

Horn, J. L. (1965). Fluid and crystallized intelligence: A factor analytic and developmental study of the structure among primary mental abilities (Niepublikowana praca doktorska). University of Illinois. Champaign.

Hunter, J. E., Schmidt, F. L. (1998). The validity and utility of selection methods in personnel psychology: Practical and theoretical implications of 85 years of research findings. Psychological Bulletin, 124(2), 262-274. https://doi. org/10.1037/0033-2909.124.2.262

Jensen, A. R. (1980). Bias in mental testing. Nowy Jork: Free Press.

Jensen, A. R. (1998). The g factor: The science of mental ability. Nowy Jork: Praeger.

Mackintosh, N. J. (2011). IQ and human intelligence. Oxford: Oxford University Press.

McGrew, K. S. (2005). The Cattell-Horn-Carroll theory of cognitive abilities: Past, present, and future. W: D. P. Flanagan, P. L. Harrison (red.), Contemporary intellectual assessment: Theories, tests, and issues (s. 136-181). Nowy Jork: The Guilford Press.

Neisser, U., Boodoo, G., Bouchard, T. J., Jr., Boykin, A. W., Brody, N., Ceci, S. J., ..., Urbina, S. (1996). Intelligence: Knowns and unknowns. American Psychologist, 51(2), 77-101. https://doi.org/10.1037/0003-066X.51.2.77

O’Toole, B. J., Stankov, L. (1992). Ultimate validity of psychological tests. Personality and Individual Differences, 13(6), 699-716. https:/ / doi.org/10.1016/0191-8869

Okely, J. A., Deary, I. J. (2020). Associations between declining physical and cognitive functions in the Lothian Birth Cohort 1936. The Journals of Gerontology Series A: Biological Sciences and Medical Sciences, 75(7), 1393-1402. https://doi.org/10.1093/ gerona/glaa023 
Ritchie, S. J., Tucker-Drob, F. M. (2018). How much does education improve intelligence? A meta-analysis. Psychological Science, 29(8), 1358-1369. https://doi. org/10.1177/0956797618774253

Salgado, J. F., Anderson, N., Moscoso, S., Bertua, C., de Fruyt, F., Rolland, J. P. (2003). A meta-analytic study of general mental ability validity for different occupations in the European community. Journal of Applied Psychology, 88(6), 1068-1081. https:// doi.org/10.1037/0021-9010.88.6.1068

Spearman, C. (1904). General intelligence objectively determined and measured. American Journal of Psychology, 15(2), 201-293. https:// doi.org/10.2307/1412107

Sternberg, R. J., Detterman, D. K. (1986). What is intelligence?: Contemporary viewpoints on its nature and definition. Norwood: Ablex Publishing Corporation.

Sternberg, R. J., Grigorenko, E. L., Bundy, D. A. (2001). The predictive value of IQ. Merrill-Palmer Quarterly, 47(1), 1-41. https://doi.org/10.1353/mpq.2001.0005

Strenze, T. (2007). Intelligence and socioeconomic success: A meta-analytic review of longitudinal research. Intelligence, 35(5), 401-426. https://doi.org/10.1016/j. intell.2006.09.004

Thurstone, L. L. (1938). Primary mental abilities. Chicago: University of Chicago Press.

Whalley, L. J., Deary, I. J. (2001). Longitudinal cohort study of childhood IQ and survival up to age 76. British Medical Journal, 322(7290), 1-5. https://doi.org/10.1136/ bmj.322.7290.819

Williams, M. V., Baker, D. W., Parker, R. M., Nurss, J. R. (1998). Relationship of functional health literacy to patients' knowledge of their chronic disease. Archives of Internal Medicine, 158(2), 166-172. https://doi.org/10.1001/archinte.158.2.166

Wissler, C. (1901). The correlation of mental and physical tests. The Psychological Review: Monograph Supplements, 3, 1-62. https://doi.org/10.1037/h0092995

Wonderlic, Inc. (1999). Wonderlic Personnel Test \& Scholastic Level Exam user's manual. Libertyville: Author. 



\section{2.}

\section{Jak inteligentnie kontrolować swoje zachowania? Siła woli w życiu codziennym}

Jan Jędrzejczyk iD https://orcid.org/0000-0002-3217-0851

Uniwersytet Warszawski, Wydział Psychologii

jan.jedrzejczyk@psych.uw.edu.pl 
$\mathrm{N}$ aukowców, psychologów w szczególności, ale jeszcze przed nimi filozofów i wszelkich myślicieli, zastanawia od lat jedna, fascynująca sprzeczność w ludzkim zachowaniu. Wyobraź sobie, że pracujesz nad jakimś projektem. Może to być raport do pracy, prezentacja, praca na zaliczenie przedmiotu czy post na bloga. Wiesz, jak się za to zabrać, potrafisz pisać tego typu rzeczy, nie jest to pierwszy raz, kiedy stoi przed Tobą takie wyzwanie. Masz także świadomość, że to jest w jakiś sposób ważne: być może chcesz na kimś zrobić dobre wrażenie swoją praca, wykonanie tego może być małym, ale istotnym krokiem na drodze do Twojej wymarzonej kariery. Innymi słowy, zrobienie tego prowadzi Cię do osiagnięcia Twoich celów, bliższych lub dalszych. Siadasz zatem przy biurku przepełniony/a wizja pięknej przyszłości, do której doprowadzi Cię skończenie tej pracy, włączasz komputer... Wtem! Nagle spostrzegasz, że na biurku panuje niesamowity bałagan. Przecież w takim otoczeniu nie da się pracować! Zaczynasz porządkować tę przestrzeń, dbasz o to, by każda rzecz znalazła się we właściwym dla niej miejscu. Gdy skończyłeś/aś, biurko zamieniło się w nieskazitelną przestrzeń sprzyjająca głębokiemu skupieniu, ale zauważasz, że okna nie są zbyt czyste i wywołuje to w Tobie irytację. Chwytasz za płyn do szyb i szmatkę... Świetnie, teraz już naprawdę wszystko jest uporzą̨dkowane i czyste, można wreszcie zabrać się do pracy. Jeszcze tylko na chwilkę sprawdzisz pocztę, może ktoś napisał? I krótki rzut oka na media społecznościowe, a nuż pojawiły się jakieś nowe polubienia. A, oczywiście jeszcze minuta na przeczytanie wiadomości, może coś ważnego zdarzyło się na świecie? Może wybuchła III wojna światowa i nawet nie ma sensu zajmować się pracą? Po dwóch godzinach takiej „chwilki” czujesz znużenie, przydałoby się zrobić jakaśs przerwę, wypić kolejną kawę, coś przegryźć. Przy okazji można włączyć ten serial, który cię ostatnio wciagnął. Ale tylko pół odcinka, bo trzeba się wreszcie wziąć do pracy! No, najwyżej jeden cały odcinek, po tym już naprawdę tylko praca...

Podobny bieg wydarzeń zapewne przydarzył się większości z nas. I to jest właśnie ta sprzeczność, to fascynujące zjawisko budzące ciekawość wśród badaczy: wiemy, że coś chcemy zrobić, mamy przekonanie, iż zrobienie tego będzie dla nas dobre, mamy możliwości, żeby to zrobić, wiemy, jak się za to 
zabrać, a jednak tego nie robimy! Jak to się dzieje, że mając chęci i możliwości, nie jesteśmy w stanie podjąć działania? Jakie procesy przebiegają wtedy w naszym umyśle? Na te właśnie pytania starają się odpowiedzieć teorie i badania dotyczące sily woli.

Siła woli, w literaturze psychologicznej określana również jako samokontrola (obu wyrażeń będę używał zamiennie), jest definiowana jako proces, dzięki któremu jesteśmy w stanie przekroczyć nawykowe reakcje, pohamować impulsywne zachowania (Tangney, Baumeister, Boon, 2004). Aby wytłumaczyć jeszcze lepiej, kiedy potrzebujemy siły woli i jak ona działa, warto powiedzieć parę słów o dwóch systemach, które działaja w naszym umyśle oraz o roli procesów poznawczych z nimi związanych.

\section{DWIE STRONY UMYSŁU: IMPULS I REFLEKSJA}

Z jednej strony wiemy, co jest dla nas korzystne w perspektywie długoterminowej, robimy plany, kierujemy naszym działaniem. Z drugiej - rozpraszamy się, sięgamy po to, co przyjemne tu i teraz, ale nie przyniesie korzyści za jakiś czas. Jest to przejaw pewnego dualizmu naszego umysłu. Już w starożytności rozważano ten paradoks - Sokrates i Arystoteles poruszali temat konfliktu rozsądku i pasji, później w tradycji chrześcijańskiej św. Augustyn wskazywał na obecną w człowieku naturę zarówno zwierzęca, jak i duchową (Hofmann, Friese, Strack, 2009). Podobnie u początków psychologii Zygmunt Freud dzielił psychikę ludzką na trzy części: „zwierzęce” id, które koncentruje się na jak najszybszym i jak najpełniejszym zaspokojeniu potrzeb, przede wszystkim cielesnych, „kulturowe” superego, czyli normy, które wyznajemy, czy też nasze sumienie i „realistyczne” ego, które stara się pogodzić sprzeczne dążenia id i superego (Freud, 2009).

Współcześnie w psychologii opisuje się tzw. modele procesów dualnych (Strack, Deutsch, 2004). Modele te sugerują istnienie dwóch oddzielnych systemów, które decydują o naszym zachowaniu. W psychologii powstało kilka teorii, które różnie nazywały te systemy: gorący i zimny (Metcalfe, Mischel, 1999), system 1 i system 2 (Kahneman, 2012), system analityczno-racjonalny i system intuicyjno-doświadczeniowy (Epstein, 1990). W niniejszej pracy będę posługiwał się nazwami system impulsywny i system refleksyjny (Hofmann $i$ in., 2009).

System impulsywny, jak można się domyślić na podstawie jego nazwy, odpowiedzialny jest za zachowania impulsywne, czyli takie, które nie wymagają namysłu, funkcjonują często automatycznie. Impuls jest czymś, co po- 
budza nas do tego typu zachowań - to może być coś smacznego do jedzenia w zasięgu naszego wzroku, telefon leżący nieopodal, po który często sięgamy, by sprawdzić, czy pojawiły się nowe wiadomości, czyli bodźce zewnętrzne, które nas ukierunkowują na pewne działania. Ale te bodźce mogą być także wewnętrzne. Na przykład w którymś momencie możemy sobie przypomnieć, że ktoś miał napisać ważną wiadomość, więc nawet gdy nie mamy w zasięgu wzroku telefonu czy komputera, poczujemy potrzebę, by do nich zajrzeć. $\mathrm{Na}$ pojawienie się impulsów wpływa również stan organizmu - gdy poczujemy głód, zaczniemy myśleć o jedzeniu i to doprowadzi do działań zbliżających nas do zaspokojenia tej potrzeby. Jeśli poczujemy nudę, zaczniemy myśleć o innej, ciekawszej czynności niż ta, którą wykonywaliśmy do tej pory. Gdy pojawi się zmęczenie, będziemy myśleć o czymś relaksujacym, niewymagającym wysiłku. Co bardzo istotne, impuls jest zazwyczaj związany z czymś przyjemnym, nagradzającym i jednocześnie bliskim zarówno fizycznie, jak i czasowo. To znaczy, że potrzebę związana z impulsem da się zaspokoić szybko i przy niewielkim wysiłku (Metcalfe, Mischel, 1999). Zatem jeśli postanowilibyśmy, że zajrzymy do mediów społecznościowych w celu poszukania rozrywki, ale, że zrobimy to dopiero za tydzień, trudno tutaj mówić o zachowaniu impulsywnym. Wartość nagradzająca takiego działania wtedy znacząco spada z powodu dużego odroczenia doświadczenia przyjemności. Podobnie jest z dystansem fizycznym; jeśli chcielibyśmy sięgnąć po ulubioną czekoladę, ale żeby ją zdobyć, musielibyśmy pojechać na drugi koniec miasta, możliwe, że ochota nam przejdzie. Jeśli nie, to trudno będzie mówić o zachowaniu impulsywnym, ponieważ musimy przedsięwziąć wiele przemyślanych kroków. Zachowania impulsywne mogą nas także nagradzać w bardziej przewrotny sposób, gdy dzięki nim unikamy czegoś przykrego. Na przykład kiedy mamy się zabrać do pracy, którą postrzegamy jako dość trudną (więc może się pojawić obawa, czy sobie poradzimy) i nagle zaczynamy robić coś innego - sprzątać biurko, czy myć okna. Sprzątanie i mycie nie są czynnościami wywołującymi euforię, ale w tym przypadku przynoszą ulgę (chwilowa), ponieważ odwracają uwagę od trudniejszego zadania.

System impulsywny opiera się na pamięci długoterminowej, która przechowuje nasze doświadczenia, sposoby zachowań, emocje z nimi związane (Hofmann i in., 2009; Strack, Deutsch, 2004). Im częściej doświadczaliśmy, że zjedzenie niezdrowego, ale smacznego posiłku sprawia przyjemność, tym bardziej wzmacniało się połączenie bodziec-zachowanie-nagroda. W psychologii mówi się w tym przypadku o uczeniu się. Nie urodziliśmy się z chęcią spoglądania na wiadomości w Internecie podczas pracy. Możemy mieć pewne wro- 
dzone potrzeby, jak poszukiwanie nowości, ale sposób, w jaki przyzwyczailiśmy się je zaspokajać, jest kwestią osobistego doświadczenia. Można więc powiedzieć, że system impulsywny opiera się na naszej osobistej historii uczenia się.

System refleksyjny opiera się z kolei na tzw. poznawczych funkcjach wykonawczych, czyli sposobach, w jaki umysł może przetwarzać informacje, zarządzać zachowaniem i sam soba. Badacze wyróżniają trzy najważniejsze funkcje wykonawcze (Hoffman, Schmeichel, Baddeley, 2012). Aktualizowanie informacji (które jest oparte na pamięci roboczej; pamięć długoterminową czasem porównuje się do dysku twardego komputera, podczas gdy pamięć robocza - do pamięci RAM, czyli systemu, w którym sa przetwarzane bieżące operacje) - przechowywanie informacji tu i teraz, potrzebnych w danej sytuacji i ich zmianę, jeśli zachodzi taka potrzeba. Ta funkcja sprawia, iż jesteśmy w stanie myśleć np. o naszym celu i drodze do niego, czy nad jakimś problemem i jego rozwiązaniami albo powtarzać w głowie krótką listę zakupów. Przełączanie zadań to funkcja umożliwiająca zmianę koncentracji z jednego celu czy działania na inne. Hamowanie to jest funkcja utożsamiana z samokontrola, czyli właśnie powstrzymywaniem działania impulsów. System refleksyjny korzysta z reprezentacji symbolicznych - języka, wyobrażeń (o tym, co będzie, czy o tym, co było lub nawet o tym, co się nigdy nie wydarzyło i nie wydarzy), nie musi działać w oparciu o realne, doświadczane bodźce. Dzięki tym funkcjom i takim reprezentacjom, system refleksyjny umożliwia nam myślenie o naszych długoterminowych celach, ocenę konsekwencji naszych działań i podejmowanie decyzji. System ten potrafi także przejąć kontrolę nad zachowaniami impulsywnymi (Hoffman i in., 2009).

Pytanie, które się nasuwa, brzmi: czy system refleksyjny ma coś wspólnego $z$ inteligencją? Inteligencja jest określana jako ogólna zdolność umysłowa związana z uczeniem się, rozwiązywaniem problemów, rozumieniem złożonych idei czy myśleniem abstrakcyjnym. (Gottfredson, 1997). Przypomina to charakterystykę systemu refleksyjnego. System ten ponadto umożliwia skuteczne osiaganie celów poprzez myślenie abstrakcyjne (czyli np. o długoterminowych konsekwencjach naszych wyborów) czy powstrzymywanie się od impulsów. Okazuje się, że inteligencja również jest związana z różnymi osiagnięciami życiowymi, jak sukces akademicki i zawodowy, czy nawet zdrowiem oraz długością życia (Deary, 2012). Co więcej, inteligentniejsze dzieci lepiej radzą sobie z odraczaniem nagrody (co, jak pokaże kolejny podrozdział, utożsamiane jest z samokontrola; Mischel, Metzner, 1962). Metcalfe i Mischel (1999) sugerowali, że system refleksyjny opiera się w znaczącej mierze na działaniu pamięci roboczej. Badacze postanowili sprawdzić, czy wymienione wcześniej funkcje 
wykonawcze wiążą się z inteligencja. Okazało się, że przełączanie zadań i hamowanie raczej nie sa związane $z$ inteligencja, ale za to aktualizowanie informacji (oparte na pamięci roboczej) jest z nią związane dość silnie (Friedman i in., 2006). Niektórzy autorzy już wcześniej postulowali, iż pamięć robocza jest wręcz podstawowym mechanizmem leżącym u podłoża inteligencji (Kyllonen, 1996). Z powyższych badań można wyciagnąć wniosek, że nie da się utożsamić system refleksyjnego z inteligencja. Jest ona jednak bardzo ważnym elementem tego systemu.

Warto podkreślić, że żaden z systemów nie jest lepszy, ich przydatność zależy od kontekstu. Oba mają odmienne funkcje, działają według innych potrzeb i oba są nam potrzebne. Gdybyśmy opierali się tylko na systemie refleksyjnym, nie przetrwalibyśmy jako gatunek. Wyobraźmy sobie naszego dalekiego przodka na sawannie, który refleksyjnie rozważa za i przeciw ucieczką, dalekosiężne jej konsekwencje i wpływ na samoocenę, gdy biegnie na niego wielki drapieżnik.

System impulsywny ma tę przewagę, że może reagować szybko i nie wymaga udziału świadomości. Mnóstwo ludzkich zachowań opiera się na nim i nie za bardzo byłoby nam potrzebne to, by nad wszystkim długo deliberować. Z drugiej strony, system refleksyjny jest ograniczony zasobami poznawczymi - nie jesteśmy w stanie ogromnie wielu informacji nieskończenie długo aktualizować, ciągle przełączać się pomiędzy kilkoma zadaniami czy nieustannie hamować działań impulsywnych. Gdy jesteśmy zmęczeni, zestresowali czy pod wpływem alkoholu, możliwości działania systemu refleksyjnego są mniejsze (Strack, Deutsch, 2004).

Choć te systemy sprawdzają się w różnych sytuacjach, to często się zdarza, że wchodzą w konflikt. Przykład z początku niniejszego tekstu to ilustruje $-z$ jednej strony chcemy zacząc pracować, $z$ drugiej wydaje się to na tyle trudnym wyzwaniem, że zabieramy się za inne czynności, łatwiejsze. Podobnie sytuacja wygląda, gdy chcemy dbać o formę fizyczną, ale często omijamy ćwiczenia, zamiast tego się relaksujemy; czy gdy próbujemy się odchudzać, a zdarza nam się sięgać po słodycze. Albo jesteśmy świadomi, iż musimy odbyć trudną rozmowę, lecz odwlekamy to w nieskończoność.

I właśnie wtedy potrzebna jest nam siła woli - by przezwyciężyć tę łatwiejsza, przyjemniejszą reakcję i „zmusić się” do tego, co może wydawać się trudne i nieprzyjemne, ale długoterminowo przyniesie więcej korzyści. Badania nad siła woli przyniosły kilka odmiennych koncepcji, które próbują opisać to zjawisko. Debata o tym, czym jest siła woli i jakie są mechanizmy jej działania, toczy się do dzisiaj. Poniższe podrozdziały opisują kolejne etapy tej debaty. 


\section{DUŻA PRZYJEMNOŚĆ CZY NATYCHMIASTOWA PRZYJEMNOŚĆ? BADANIA NAD ODRACZANIEM GRATYFIKACJI}

Wyobraźmy sobie następujący scenariusz. Uczestnik badania, rzekomo dotyczącego uczenia się, siedzi w pokoju, do którego po chwili wchodzi eksperymentator. Kładzie on przed badanym dwie rzeczy: precla i słodką piankę. Pyta się, co wolałby zjeść. Większość wybiera słodką piankę. Eksperymentator chwali ten wybór, ale mówi, że na chwilę musi wyjść - dopiero gdy wróci, uczestnik będzie mógł zjeść tę piankę. Jeśli jednak nie będzie chciał czekać, to może zawołać eksperymentatora, który szybko powróci. Ale wtedy badany będzie mógł zjeść tylko precla. Zatem albo czeka i otrzymuje upragnioną nagrodę, albo traci cierpliwość, wzywa eksperymentatora i otrzymuje tylko ten drugi przysmak, też dobry, ale nie aż tak jak pianka. Jak długo badany będzie w stanie wytrzymać, zanim zawoła eksperymentatora?

To przykład klasycznego eksperymentu Waltera Mischela, zwanego czasem testem Marshmallow (czyli angielskiej nazwy pianki cukrowej; Mischel, Metzner, 1962; zob. też: Mischel, Ebbesen, 1970; Mischel, Ebbesen, Zeiss, 1972). Polegał on na tym, że badanym proponowano dwa rodzaje słodyczy, czasami to były precle i pianki, czasami zamiast pianek ciastka czy dwa rodzaje czekolady - tańsza i droższa. Można było dostać albo tę „gorsza” wersję słodyczy, czyli mniej wartościową nagrodę w dowolnej chwili (wystarczyło zawołać eksperymentatora), albo wytrwać i otrzymać bardziej wartościową nagrodę. Następnie mierzono czas, po którym badany wzywał eksperymentatora. Ten rodzaj badań nazywano paradygmatem odroczonej gratyfikacji (Mischel, Shoda, Rodriguez, 1989) - mierzył on bowiem, na ile jesteśmy w stanie powstrzymać się przed przyjemnością tu i teraz w imię większej przyjemności, ale dostępnej dopiero za jakiś czas. W eksperymentach badane były dzieci w wieku około 4 lat. Ich funkcje wykonawcze (czyli system refleksyjny) nie są aż tak rozwinięte jak u dorosłych (Zelazo, Craik, Booth, 2004), więc zapewne dorosły potrafiłby poczekać znacznie dłużej.

W wyżej wymienionych przykładach również można mówić o konflikcie systemu impulsywnego - chęci natychmiastowej przyjemności, nawet jeśli to będzie tylko precel, z systemem refleksyjnym, który skłania jednak do oczekiwania na większą nagrodę. Choć sam Mischel odniósł swoje badania do modeli procesów dualnych znacznie później (Metcalfe, Mischel, 1999).

Co interesujące, Mischel próbował odkryć, co sprawiało, że dzieci potrafiły wytrzymać dłużej i sięgnąć po tę lepszą słodkość. Innymi słowy, sprawdzał, co wpływało na skuteczność siły woli. W jednym z badań (Mischel, Ebbsen, 1970) obie nagrody - mniejsza natychmiastowa i większa odroczona w jednej 
grupie były odkryte, w zasięgu wzroku dzieci. W drugiej grupie także były umieszczone w pokoju, ale zostały przykryte. Badacze zakładali, że jeśli dzieci będą widziały nagrodę, będzie im znacznie łatwiej poczekać na tę bardziej wartościowa. Jednak wyniki badania pokazały coś zupełnie odwrotnego - słodycze w zasięgu wzroku sprawiały, iż dzieci znacznie szybciej wzywały eksperymentatora. W kolejnym badaniu (Mischel i in., 1972) dzieci podzielono jeszcze inaczej: jedne poproszono, by myślały o słodyczach, które mogą dostać, drugie - by myślały o czymś sprawiającym przyjemność: śpiewaniu piosenek, zabawie zabawkami czy czymkolwiek innym. Okazało się, że myślenie o słodyczach znacząco skracało czas, po którym dzieci wzywały eksperymentatora. Z kolei skupienie się na innego rodzaju przyjemnościach prowadziło do tego, iż dzieci wytrzymywały dłużej. W jeszcze innym badaniu (Moore, Mischel, Zeiss, 1976) młodych badanych poproszono o tworzenie wyobrażeń podczas mierzenia się z pokusa otrzymania słodyczy jak najszybciej. Pierwsza grupa miała sobie wyobrażać słodycze jak najbardziej realnie, czyli tak, jak je widzą w rzeczywistości i że moga je dotknaćc. Druga grupe poproszono, by również wyobrażała sobie te słodycze, ale jako kolorowy obrazek w ramce, nie coś prawdziwego. Dzieci wyobrażające sobie abstrakcyjny obrazek, a nie prawdziwe słodycze, potrafily znacząco odroczyć sięgnięcie po nagrodę. Dlaczego tak to zadziałało?

Wyniki tych badań można odnieść do działania systemu impulsywnego i refleksyjnego (gorącego i chłodnego według Mischela i Metcalfe'a [1999]). W pierwszym z tych badań (Mischel, Ebbsen, 1970) przez kontakt wizualny, system impulsywny dzieci był zapewne mocno pobudzony, ponieważ doświadczały tu i teraz obecności pokusy, więc trudno było im się powstrzymać od sięgnięcia po nią. Podobnie w drugim badaniu, gdy miały myśleć o słodyczach, tutaj niekoniecznie musiały je widzieć (wariant z zakrytymi słodyczami), ale samo myślenie także potrafiło wzbudzić system impulsywny (Mischel i in., 1972). Ale gdy w tym samym badaniu myślały o czymś innym, czyli odwracały uwagę, czy wręcz zagłuszały system impulsywny - nie działał on tak silnie i dzieci potrafiły dłużej czekać. W trzecim badaniu (Moore i in., 1976), poprzez wyobrażanie sobie abstrakcyjnego obrazka, a nie realnego bodźca uruchamiano system refleksyjny, który posługuje się właśnie symbolicznymi reprezentacjami (czyli np. obrazkami). I to także prowadziło do wzmocnienia siły woli dzieci. Badania Mischela ilustruja zatem, jak za pomocą osłabiania i wzmacniania dwóch stron naszego umysłu jesteśmy w stanie skuteczniej stosować samokontrolę. 


\section{SIŁA WOLI JAKO MIĘSIEŃ}

Choć do badań Waltera Mischela w paradygmacie odroczonej gratyfikacji nadal odnosi się wielu naukowców, przez ostatnie 20 lat w psychologii królowało inne spojrzenie na siłę woli. Koncepcję, która dominowała przez wiele lat w badaniach, dobrze ilustruje pewien specyficzny nawyk byłego prezydenta Stanów Zjednoczonych, Baracka Obamy. Obama miał w swojej szafie wiele garniturów, ale tylko w dwóch kolorach: granatowym i szarym, co łatwo sprawdzić przeglądając zdjęcia w Internecie, trudno go bowiem zobaczyć w garniturze o innym kolorze. Podobnie sprawa wygląda z Markiem Zuckerbergiem, założycielem Facebooka. Wiele zdjęć prezentuje go w prostym T-shircie o zawsze tym samym kolorze - ciemnoszarym (przynajmniej do momentu aż zaczął być częstym gościem w amerykańskim Kongresie, przesłuchiwany jako świadek w sprawie nieprawidłowego używania danych osobowych przez Facebooka). Steve Jobs i jego charakterystyczny pulower to kolejny przykład. O co chodzi? Czy to fanaberie ludzi zarządzających państwem i potężnymi firmami? Co to ma wspólnego z siła woli? $\mathrm{Na}$ to pytanie odpowiada koncepcja samokontroli przedstawiona poniżej.

Chyba większość z nas kojarzy ten moment, gdy wracamy po całym dniu pracy do domu, zmęczenie już mocno daje się we znaki, ale jest jeszcze parę rzeczy do zrobienia. Być może postanowiliśmy rozwijać nowy nawyk, np. ćwiczenia po pracy, albo nowa, zdrowszą dietę, która wymaga nauczenia się paru nowych przepisów, albo chcemy nadrobić zaległości w pracy. Ale czujemy takie wyczerpanie, że nawet pomimo postanowienia, trudno się nam za to zabrać. Może jednak warto odpocząć po całym dniu, a nie jeszcze pracować czy ćwiczyć, albo chociaż zjeść coś dobrego, co można szybko przygotować lub zamówić. Innymi słowy, czujemy wyczerpanie i brak nam siły woli, by realizować ten wcześniejszy plan...

Tak jakby nasz umysł, nasza wola, przypominała nieco działanie mięśnia. Nasze mięsnie dość chętnie się nas słuchają (przynajmniej te poprzecznie prążkowane) - możemy je kurczyć i rozkurczać, czyli wykonywać ruchy, podnosić rzeczy, ćwiczyć. Jednocześnie gdy angażujemy je do bardzo trudnych zadań, wymagających długiego napięcia czy podnoszenia ciężkich rzeczy - nie możemy tego robić bez końca, w którymś momencie mięśnie się buntują, nie chcą już działać i potrzebują odpoczynku. Jeśli damy im ten odpoczynek, mięśnie się zregenerują i znowu będziemy mogli ich bez problemu używać.

To może dlatego trudno nam realizować wymagające postanowienia po wyczerpującym dniu? Być może nasz „mięsień siły woli” się zmęczył, wyczerpał i potrzebuje regeneracji? Dlatego jesteśmy w stanie kilka razy oprzeć się 
różnym pokusom, ale gdy napotkamy ich wiele, to w końcu się łamiemy? Podobny tok myślenia zaprowadził Roya Baumeistera i jego współpracowników do zaproponowania siłowego modelu samokontroli (zwanego też modelem zasobowym), który porównuje właśnie siłę woli do działania mięśnia (Baumeister, Bratslavsky, Muraven, Tice, 1998). Tak jak inni badacze zastanawiał się, jak to się dzieje, że jesteśmy w stanie wywierać wpływ na nasze zachowanie w obliczu pokus, ale jednak czasami ponosimy porażki na tym polu. Poprzez serię interesujących eksperymentów Baumeister wykazał, iż siła woli nie zawsze działa, ponieważ opiera się na ograniczonym paliwie, czy też zasobie (stąd druga nazwa tej koncepcji - zasobowy model samokontroli), które dość szybko się wyczerpuje (Baumeister i in., 1998; Baumeister, Vohs, Tice, 2007).

Jedno z badań rzekomo dotyczyło postrzegania smaku. Uczestników poproszono, żeby nie jedli przed badaniem, by pozostać na czczo. Gdy pojawili się na badaniu, pierwszą rzeczą, której doświadczyli, był zniewalający zapach świeżo upieczonych czekoladowych ciasteczek. Na stole można było zauważyć dwa rodzaje jedzenia - po jednej stronie mnóstwo czekoladowych ciasteczek, które już wcześniej dało się wyczuć węchem, po drugiej - miskę rzodkiewek. Po chwili eksperymentatorka zaczynała szczegółowo opowiadać o badaniu (ta opowieść, jak to się zdarza często w badaniach psychologicznych, okaże się nieprawdą; służy to temu, by badani nie domyślili się prawdziwego celu eksperymentu; dopiero na końcu całego badania wyjaśniany jest prawdziwy cel i przebieg). Następnie z ust eksperymentatorki uczestnicy usłyszeli bardzo złe wieści: mogą spróbować wyłącznie rzodkiewek, ciastka nie wolno im tknąć. Eksperymentatorka wychodzi, a badani z umiarkowaną chęcią zaczynają jeść rzodkiewki, jednocześnie patrząc z utęsknieniem na czekoladowe ciastka, próbując myśleć o czym innym lub wyobrażać je sobie jako nierealistyczne obrazki niczym dzieci z badań Waltera Mischela. Na szczęście eksperymentatorka wraca zaledwie po 5 minutach. Prosi o wypełnienie kilku kwestionariuszy i rozwiązanie zadań: pokazuje uczestnikom figurę geometryczną na kartce, a ich zadaniem jest prześledzenie ołówkiem wszystkich linii tej figury. Ale są dwie zasady: nie można oderwać ołówka od kartki i poprowadzić ołówka po tej samej linii drugi raz. Można próbować dowolną liczbę razy i nie ma ograniczeń czasowych. Ważne jest, by skończyć tę figurę. Jeśli ktoś chce zakończyć badanie, zanim ukończy zadanie, może wezwać eksperymentatorkę, która teraz wychodzi. Badani rozpoczynają zadanie. Okazuje się dość trudne. Nawet bardzo trudne, a po 15 minutach czują się wyczerpani.

To jest przykład badania, które przeprowadzano, by sprawdzić, czy model siłowy ma sens (Baumeister i in., 1998). O co w nim chodziło? Zaczynając 
od końca - zadanie z figurą było nierozwiązywalne, nie dało się go wykonać, opierając się na tych zasadach. Badaczy interesowało, jak długo ktoś wytrwa, próbując rozwiązać ten problem. Do czego były potrzebne ciastka? Otóż badanych podzielono na dwie grupy - jedna mogła spróbować tylko rzodkiewek, druga mogła skosztować czekoladowych ciastek. Powstrzymanie się przed sięgnięciem po ciastka, szczególnie przy ich intensywnym zapachu, było trudne - badacze założyli, że będzie do tego potrzebna siła woli. Faktycznie, uczestnicy badania później przyznali, iż musieli się świadomie powstrzymywać przed ta pokusa. Jedna grupa zatem musiała użyć samokontroli, by nie sięgnąć po ciastka, druga mogła po nie sięgać. A następnie obie grupy musiały ponownie wykorzystać swą siłę woli, by jak najdłużej wytrwać przy nierozwiązywalnym zadaniu. Innymi słowy, część osób dwa razy wykorzystywała siłę woli, część tylko raz.

Powyższe badanie to przykład tzw. paradygmatu dwóch zadań używanego w badaniach nad siłowym modelem samokontroli. Polega on na tym, że wszyscy badani przechodzą przez dwa zadania. Drugie zadanie zawsze wymaga użycia siły woli, zaś przy pierwszym jest podział na grupy: jedna musi skorzystać ze swojej siły woli, druga nie. Na końcu okazało się, iż osoby powstrzymujące się przed zjedzeniem czekoladowych ciastek wytrzymywały przy drugim zadaniu znacznie krócej.

Wynik ten sugeruje, że podczas opierania się czekoladowym ciastkom, „mięsień” samokontroli się zmęczył i już nie dał rady działać sprawnie. Z kolei u osób, które mogły swobodnie konsumować ciastka, „mięsień” ten nie był używany, odpoczywał, więc mógł dłużej pracować w następnym zadaniu. Ten stan, w którym trudno nam zastosować samokontrolę, ponieważ zużyliśmy jej zasób, stan zmęczenia „mięśnia samokontroli”, nazwano wyczerpaniem ego (Baumeister i in., 1998). Jest to pewien ukłon w stronę Zygmunta Freuda (2009), którego koncepcję wspomniałem wcześniej. Według niej to właśnie ego odpowiadało za racjonalne kierowanie zachowaniem, radzac sobie z rzeczywistościa, godząc potrzeby zwierzęcego id i społecznego superego. Jednak jest to proces na tyle wymagajacy, że, w koncepcji Baumeistera, ego po takim racjonalnym zarządzaniu działaniem, wyczerpuje się, czyli traci jakiś rodzaj energii i potrzebuje się zregenerować.

W języku psychologii poznawczej zamiast ego mówilibyśmy raczej o funkcjach wykonawczych (choć oczywiście nie są to pojęcia synonimiczne). Model siłowy można zatem odnieść do procesów dualnych: systemu impulsywnego i systemu refleksyjnego. Także w tej koncepcji system refleksyjny jest odpowiedzialny za siłę woli, choć Baumeistera interesowała tylko jedna funkcja systemu 
refleksyjnego: hamowanie. O ile Mischel w swoich eksperymentach z odroczoną gratyfikacją sprawdzał, jak na siłę woli przekłada się działanie obu systemów oraz jak możemy te systemy wykorzystać, by nie ulec pokusie, Baumeister docieka raczej mechanizmu, który leży u podłoża systemu refleksyjnego. Jak już wcześniej mówiliśmy, system refleksyjny opiera się na ograniczonych zasobach poznawczych (Strack, Deutsch, 2004). Baumeister idzie jeszcze krok dalej i sugeruje, że system refleksyjny, a przynajmniej związana z nim funkcja hamowania, zależna jest od konkretnego, szybko wyczerpującego się zasobu (Baumeister i in., 1998; Baumeister i in., 2007).

To również tłumaczy dość ograniczony wybór kolorystyczny garniturów Baracka Obamy. Jak sam mówi, zależy mu na tym, by nie podejmować decyzji „co ubrać”, ponieważ w ciagu zwykłego dnia ma wiele znacznie ważniejszych decyzji do podjęcia (Lewis, 2012). A każda decyzja nieco uszczupla zasób siły woli - więc warto eliminować te, która nie są istotne, by móc użyć „mięśnia” siły woli do tych naprawdę ważnych. Zatem nie jest to fanaberia, czy u Obamy, czy u Zuckerberga, tylko działanie zgodnie z siłowym modelem samokontroli.

W kolejnych latach powstało wiele badań, które rozwijały model Baumeistera. Badano siłę woli w wielu różnych kontekstach - uczestnicy mieli za zadanie już nie tylko powstrzymywać się od zjedzenia ciastek, ale kontrolować swoje emocje, np. powstrzymywać ich ekspresję, czy ograniczać agresywne zachowania, skupiać się na czymś intensywnie przez chwilę, opanowywać swoje myśli, np. powstrzymywać stereotypy, wykonywać zadania logiczne, ograniczać wydatki, podejmować różne decyzje, zachowywać się uprzejmie wobec ludzi oraz wiele innych (Baumeister i in., 2007; Hagger, Wood, Stiff, Chatzisarantis, 2010). W 2010 roku Hagger i in. przeprowadzili metaanalizę badań nad wyczerpaniem ego. Metaanaliza jest rodzajem badania, które zbiera wiele różnych pojedynczych eksperymentów i na ich podstawie oblicza ogólny wynik. Dzięki temu jest znacznie bardziej wiarygodna niż pojedyncze badanie. Autorzy wykazali, na podstawie 83 badań, że faktycznie zjawisko wyczerpania ego występuje - osoby, które wcześniej użyły siły woli, przy drugim jej użyciu radziły sobie gorzej w różnych zadaniach niż osoby, które nie musiały wcześniej zużywać swojej siły woli (czyli były w pewnym sensie „wypoczęte”). To był bardzo mocny argument za modelem siłowym Baumeistera - wyglądało na to, że odkryto mechanizm działania samokontroli.

Z tych badań wynika interesująca konkluzja: posiadamy jeden, globalny zasób, na którym opiera się siła woli. To znaczy, że niezależnie czy próbujemy się powstrzymać przed zjedzeniem słodyczy, czy skupić na pracy, czy radzić 
sobie z niechcianymi myślami albo zarządzać emocjami, korzystamy z tego samego źródła. Zatem jeśli wykorzystamy samokontrolę do tego, by się nie rozpraszać i skupić na pracy, później łatwiej możemy ulec pokusie zjedzenia czegoś smacznego. Albo jeśli będziemy próbowali powstrzymać nasze emocje, za chwilę będziemy bardziej podatni na rozproszenie się podczas pracy. Znamienne jest również to, iż w większości eksperymentów nad wyczerpaniem ego, czas zadania, które utrudniało późniejsze użycie siły woli, był raczej krótki - w wyżej opisanym badaniu (Baumeister i in., 1998) było to tylko 5 minut, w innych zadaniach też po kilka minut, czasami około 10 minut, a z metaanalizy (Hagger i in., 2010) wynikało, że czas nie miał wielkiego znaczenia. Zatem nawet krótkie czynności mogą uszczuplić zasoby samokontroli. Ilustruje to zreszta przykład Obamy - nawet gdyby miał garnitury we wszystkich kolorach tęczy, wybór jednego na dany dzień to raczej szybka decyzja.

Jeśli zasoby siły woli tak szybko się wyczerpuja, to powstaje pytanie: jak sobie z tym poradzić? Dwa rozwiązania wydają się oczywiste. Po pierwsze, możemy iść drogą Obamy i ograniczać sytuacje, w których używamy samokontroli, tak by wykorzystać jej skromne zasoby na naprawdę ważne rzeczy. Po drugie, dbać o odpoczynek, by nasz „mięsień siły woli” mógł się zregenerować. A co by było, gdyby dało się w jakiś sposób szybko uzupełnić paliwo samokontroli? Oczywiście najpierw trzeba by wiedzieć, czym ono tak naprawdę jest. I to pytanie również zadawali sobie badacze.

Przez wiele lat idea zasobu, na którym opiera się siła woli, pełniła funkcję obrazowej metafory, dobrze wyjaśniającej mechanizm działania tego fenomenu. W 2007 roku badacze postanowili sprawdzić, czy faktycznie taki obiektywny, biologiczny zasób istnieje i czy to od niego zależy działanie samokontroli (Gailliot i in., 2007). Kandydatem na ten zasób okazała się glukoza, ponieważ jest ona głównym źródłem energii mózgu każdego ssaka, w szczególności u ludzi, których mózg zużywa $20 \%$ całej energii pochodzącej z glukozy, pomimo że stanowi zaledwie 2\% masy człowieka (Mergenthaler, Lindauer, Dienel, Meisel, 2013). Gailliot i Baumeister (2007) przekonująco argumentowali, że istnieje wiele tropów, które potwierdzają ich hipotezę: niski poziom glukozy był łączony m.in. $\mathrm{z}$ zachowaniami kryminalnymi, problemami z koncentracja czy z zachowaniami impulsywnymi. W celu zweryfikowania tego przypuszczenia, badacze przeprowadzili aż dziewięć badań (Gailliot i in., 2007). Taka liczba była im potrzebna, by odpowiedzieć na kilka pytań badawczych - czy faktycznie po zadaniu wymagającym użycia samokontroli poziom glukozy obniża się, czy poziom glukozy wiąże się z poziomem wykonania zadania, oraz wreszcie - czy uzupełnienie glukozy prowadzi do wzmocnienia samokontroli. Ponadto 
wykorzystano kilka rodzajów zadań - autorzy chcieli od razu ocenić, czy te wyniki można uogólnić na różne konteksty, w których wymagane jest użycie siły woli. U badanych mierzono poziom glukozy przed i po wykonaniu zadań. Okazało się, iż faktycznie po zadaniu ten poziom był niższy, a w kolejnej serii badań wykazano również, że im mniejszy poziom glukozy we krwi, tym gorsze wyniki zadania. W ostatniej serii badań po wykonaniu pierwszego zadania, które miało uszczuplić ich zasoby siły woli (czyli, wedle założeń, właśnie glukozę) jednej grupie badanych podawano lemoniadę z wysoką zawartościa glukozy, drugiej - napój, który nie zwiększał poziomu glukozy. Okazało się, że osoby wzmocnione napojem z glukozą nie doświadczały wyczerpania ego. Te wyniki umocniły tezę, że zasób stojący za samokontrolą nie jest jedynie metafora, tylko naprawdę istnieje i jest nim glukoza. Zatem kolejnym sposobem, by wzmocnić swoją siłę woli, jest dostarczenie sobie glukozy - z powyższych badań wynika, iż pozwoli to dłużej opierać się pokusom.

Model siłowy porównuje siłę woli do mięśnia. Jak mięsień, samokontrola może przez jakiś czas „pracować”, ale w końcu się „zmęczy” i potrzebuje odpoczynku. Ale mięśnie maja jeszcze jedną właściwość. Można je trenować, aby były bardziej wytrzymałe. Czy to możliwe, że i w tym aspekcie siła woli przypomina mięsień? Muraven, Baumeister i Tice (1999) zaprosili do badania studentów, których zadaniem było pomęczenie się z urządzeniem zwanym ściskaczem dłoni - przedmiotem do ćwiczeń, który stawia opór przy ściskaniu go, więc utrzymanie ścisku staje się coraz trudniejsze i trzeba wykorzystywać siłę woli, by to robić długo. Na początku studenci byli proszeni o ściskanie tego urządzenia tak długo, jak mogli. Następnie zostali poproszeni o kolejne zadanie wymagające samokontroli - mieli nie myśleć o białym niedźwiedziu. To często używane w badaniach zadanie wymagające samokontroli (Wegner, Schneider, Carter, White, 1987). Jeśli podsuwa się badanym konkretną rzecz, o której mają nie myśleć, to ona oczywiście zacznie pojawiać się w myślach i trzeba się kontrolować, by przekierować swoje myśli na coś innego. Po tym kolejny raz używali ściskacza do dłoni. Oczywiście za każdym razem mierzono, jak długo są w stanie utrzymać ścisk. Dokładnie tę samą procedurę powtórzono później, ale dopiero po dwóch tygodniach. Przez te dwa tygodnie studenci mieli wykonywać różne ćwiczenia, które wymagają siły woli - jedna grupa musiała zwracać uwagę przez cały ten czas na utrzymanie dobrej postury, druga - na takie myślenie o emocjach, by utrzymać dobry nastrój, kolejne dwie miały zapisywać wszystko, co jedza. I jeszcze jedna grupa nie robiła nic (to grupa kontrolna). Co się okazało po dwóch tygodniach? O ile pierwsze podejście do ściskacza (to przed niemyśleniem o białym niedźwiedziu) nie różniło się od 
początkowego pomiaru, to drugie podejście wychodziło znacznie lepiej tym osobom, które w jakiś sposób ćwiczyły samokontrolę przez te dwa tygodnie w porównaniu z grupa kontrolną (wyjątkiem była jedynie grupa, która miała dbać o swój nastrój - tutaj wyniki były podobne do grupy kontrolnej).

Na podstawie tych badań wyciagnięto wniosek, że siłę woli da się ćwiczyć. Co interesujące, badani przez te dwa tygodnie pomiędzy pomiarami wykonywali zadania, które w żaden sposób nie były związane ze ściskaniem dłoni - a jednak po takim ćwiczeniu byli w stanie dłużej utrzymać ścisk. Potwierdza to kolejny raz założenie, iż zasób samokontroli jest ogólny, tzn. niezależnie do jakiej czynności go wykorzystujemy, tak samo się uszczupla lub wzmacnia. Zatem dowolne ćwiczenie siły woli powinno nam zwiększyć ilość tego zasobu w różnych kontekstach. Ważne jest również to, że ten efekt widoczny był przy drugim ściskaniu, tj. po zadaniu z białym niedźwiedziem (czy raczej docelowo bez białego niedźwiedzia w myślach). To oznacza, iż po treningu samokontroli jesteśmy bardziej odporni na wyczerpanie ego.

Założenia i przewidywania modelu siłowego Roya Baumeistera (Baumeister $\mathrm{i}$ in., 1998) potwierdziły się w wielu badaniach. Wyczerpanie ego, czyli stan wskazujący na zużycie zasobu, na którym opiera się siła woli, polegający na tym, że trudno nam kolejny raz jej użyć, pojawiał się w bardzo wielu kontekstach (Hagger i in., 2010). Wskazywało to na fakt, iż mamy jeden, ogólny zasób, z którego czerpiemy niezależnie od tego, czy chcemy powstrzymać się przed rozproszeniem, przed odczuwaniem emocji czy przed różnymi niepożądanymi zachowaniami. Okazało się również, że zasób nie jest tylko metaforą - dowiedziono, iż paliwem samokontroli jest glukoza (Gailliot i in., 2007). Metafora mięśnia także jest niezwykle trafna - siłę woli, jak mięsień, można trenować (Muraven i in., 1999). Ta elegancka i obrazowa koncepcja zdaje się dobrze tłumaczyć fenomen, który zastanawiał myślicieli i badaczy od lat. Tak, nasza natura jest dwoista, działa w nas zarówno system impulsywny, jak i system refleksyjny. Temu drugiemu często udaje się wywrzeć wpływ na nasze zachowanie, powstrzymać impulsy - ale nie zawsze, ponieważ czasami brakuje mu zasobu - glukozy - albo jest niewytrenowany.

Zanim jednak zakupimy zestaw garniturów i T-shirtów w tym samym kolorze, zaczniemy spożywać pokarmy z dużą zawartościa glukozy i planować trening siły woli, przyjrzyjmy się koncepcji Baumeistera z innej perspektywy. 


\section{LAT BADAŃ NAD SIŁĄ WOLI. WIELKA POMYŁKA?}

Badacze zaproponowali jeszcze jeden wariant eksperymentu w paradygmacie dwóch zadań ze zmienionym jednym istotnym szczegółem. Tym razem nie chodziło o powstrzymywanie się przed czekoladowymi ciastkami, tylko niemyślenie o białym niedźwiedziu. Po tym badaniu osoby znowu miały rozwiązywać zadanie geometryczne. Znacząca zmiana polegała na tym, że przed tym zadaniem do części z nich przychodził eksperymentator, raz jeszcze dziękował za udział i tłumaczył, iż to badanie jest naprawdę ważne. Okazywało się, że eksploruje ono nowe metody leczenia choroby Alzheimera. Uczestnicy byli zaskoczeni, nie zdawali sobie sprawy, iż uczestniczą w czymś tak doniosłym, czymś, co może pomóc milionom ludzi na całym świecie. Dlatego też sprawnie zabierali się za zadanie geometryczne i starali się wytrwać w nim jak najdłużej.

Taki eksperyment przeprowadzili Muraven i Slessareva w 2003 roku. Osoby, którym powiedziano, że to badanie może pomóc w opracowaniu nowych metod leczenia choroby Alzheimera, nie doświadczyły wyczerpania ego, czyli radziły sobie z drugim zadaniem tak dobrze jak osoby, które wcześniej wykonywały jakieś łatwe zadanie i mogły myśleć o białym misiu, ile chciały. O co chodzi z tą chorobą Alzheimera? To nic innego, tylko uświadomienie badanym, że to, co robia, jest ważne - czyli zwiększenie ich motywacji. Autorzy artykułu zwiększali motywację jeszcze na dwa sposoby: zapłatą pieniężną i przekonaniem, że trening trudnego zadania w końcu się opłaci i ich rezultaty będą lepsze. W każdej z tej wersji uczestnicy nie doświadczali wyczerpania ego. Czyli odpowiednio wysoka motywacja sprawia, że możemy swobodnie korzystać z naszej samokontroli.

Jednakże, zgodnie z modelem siłowym, siła woli opiera się na ograniczonym zasobie, i tym zasobem jest konkretna substancja w naszym mózgu glukoza. Jakie znaczenie może tu mieć motywacja? Dzięki motywacji nagle będziemy mieli więcej glukozy w mózgu? Badacze zasugerowali dwa, nieco odmienne, wyjaśnienia tych wyników: hipotezę studni i hipotezę konserwacyjna (Muraven, Slessareva, 2003). Hipoteza studni sugerowała, że im więcej zużyjemy zasobu, tym trudniej jest go później wydobyć. Podobnie jak dzieje się ze studnią, która stopniowo wysycha, gdy się często z niej wydobywa wodę. Ale jeśli ma się wystarczająca motywację, można sięgnać jeszcze głębiej, by wydobyć wodę czy, w przypadku tego badania, zasób samokontroli. Hipoteza konserwacyjna postuluje zaś, iż mamy tendencję do konserwowania naszych zasobów, czyli niezużywania wszystkiego, co mamy do dyspozycji. A im bardziej jesteśmy wyczerpani, tym bardziej konserwujemy te resztki w celu ich 
późniejszego wykorzystania. Motywacja w tym przypadku zadziałałaby w taki sposób, że zmniejszałaby naszą tendencję do konserwacji i bylibyśmy skłonni więcej tych zasobów zużyć. Muraven, Shmueli i Burkley (2006) przedstawili badania, które przemawiały za hipotezą konserwacyjna.

Natomiast to wyjaśnienie budzi innego rodzaju wątpliwości. Model siłowy wskazywał, że mamy ograniczoną ilość zasobu odpowiedzialnego za samokontrolę i każde jej wykorzystanie go uszczupla. Na podstawie badań Muraven $i$ in. (2006) proponuje się zaś, iż mamy go więcej, czy potrafimy go „zachować na trudniejsze czasy", czy też możemy głębiej sięgnać do tego magazynu, w którym zasób się znajduje. Jeśli tak, to ile właściwie mamy tego zasobu? Jeśli nie będziemy chcieli go „konserwować”, to jak wtedy będziemy mogli wykorzystywać naszą siłę woli? Jak głęboko możemy po niego sięgnąć? Hipoteza konserwacyjna sprawia, że przewidywania modelu siłowego stają się nieco rozmyte. Jeśli sięgniemy do tych zasobów, które zazwyczaj „konserwujemy”, to być może będziemy w stanie cały czas stosować samokontrolę?

Przeczy tej tezie badanie Vohs, Baumeistera i Schmeichela (2012), w którym wykazano, że owszem, motywacja zapobiega wyczerpaniu ego, ale jeśli to wyczerpanie będzie naprawdę duże - badani wykonają nie jedno zadanie wymagające samokontroli, ale kilka - to motywacja już nie zadziała. Choć istnieją też badania wskazujące na to, iż przez podwyższenie motywacji można wykonywać wymagające zadania naprawdę długo (Boksem, Meijman, Lorist, 2006).

Pojawiły się również inne badania, w których dodatkowe czynniki potrafily zapobiec wyczerpaniu ego. Przy dużej motywacji sięgamy do zasobów siły woli, które zwykle konserwujemy. To dość przekonująca teza. Ale dlaczego tak miałoby się dziać, gdy odczuwamy pozytywne emocje (Tice, Baumeister, Shmueli, Muraven, 2007), obejrzymy telewizję (Derrick, 2013), pomyślimy sobie o zadaniu jako teście na siłę woli (Magen, Gross, 2007) albo jako o zabawie (Werle, Wansink, Payne, 2014), czy nawet zapalimy papierosa (Heckman, Ditre, Brandon, 2012)?

Interesująca koncepcja, która także podważa założenia modelu siłowego, jest propozycja Job, Dweck i Waltona (2010). Zasugerowali oni, że być może to, czy jesteśmy w stanie używać siły woli dłużej, zależy od przekonań, a zatem od tego, czy np. wierzymy, iż nasza siła woli nie wyczerpuje się tak łatwo, mamy jej dużo, czy myślimy o niej jako o bardzo ograniczonym zasobie (czyli dokładnie tak, jak to proponuje Baumeister w modelu siłowym). W eksperymentach te przewidywania się potwierdziły - osoby wierzące, że mają naprawdę silną siłę woli, nie doświadczały wyczerpania ego. Osoby zaś wierzące w ograniczoną, szybko wyczerpywalną samokontrolę - faktycznie 
gorzej radziły sobie z ponownym jej wykorzystaniem. Dodatkowo okazało się, iż ludzie wierzący w nieograniczoną siłę woli lepiej radzą sobie, gdy mają szczególnie dużo zadań i muszą wykonywać wysiłek przez dłuższy czas - co jest kolejnym argumentem przeciw hipotezie konserwacyjnej (Bernecker, Job, 2015). W naszych badaniach postanowiliśmy sprawdzić, czy przekonania o sile woli wiążą się z osobowością i inteligencją (Jędrzejczyk, Zajenkowski, 2018). Związki te mogłyby wskazać genezę przekonań, np. osoby o określonych cechach osobowości wierza, że siła woli jest nieograniczona. Przypuszczaliśmy również, że inteligencja może być podstawą myślenia o sile woli. Jak wcześniej zostało wspomniane, inteligencja wiąże się z lepszym radzeniem sobie w życiu na polu akademickim, zawodowym czy nawet zdrowotnym. Być może osoby inteligentne lepiej i szybciej radzą sobie z różnymi wyzwaniami, dlatego zaczynają myśleć, iż zapas siły woli wcale tak łatwo się nie wyczerpuje. Wyniki badania pokazały jednak, że przekonania o sile woli wiązały się jedynie z cechami osobowości i to raczej słabo. $Z$ inteligencja zaś zupełnie nie. Te wyniki sugerują, że przekonania o sile woli w dużej mierze są niezależne od osobowości i inteligencji. Wydawało się, że model siłowy dobrze wyjaśnia, jak działa nasza siła woli. Mamy ograniczony poziom zasobu, na którym się ona opiera, glukozę, dlatego nie jesteśmy w stanie stale opierać się pokusom. Jednak przytoczone powyżej badania wskazują iż jesteśmy w stanie korzystać z samokontroli skuteczniej, niż sugerował to Baumeister. Pojawiły się wątpliwości, czy model siłowy trafnie opisuje to zjawisko. Wyniki opublikowane w artykułach naukowych w roku 2014 i 2015 można porównać do bomby atomowej, która spadła na tę koncepcję. Precyzując, ukazały się metaanalizy (Carter, Kofler, Forster, McCullough, 2015; Carter, McCullough, 2014), które ponownie oceniały badania nad wyczerpaniem ego. Ich konkluzją było, że ten efekt jest bardzo słaby albo wręcz w ogóle nie występuje. Oznaczałoby to, iż ludzie nie traca zasobów siły woli tak, jak to przewiduje model siłowy. Nowa analiza danych nie potwierdza więc tego modelu.

\section{KRYZYS REPLIKACYJNY}

W 2015 roku trzęsienie ziemi miało miejsce nie tylko w odniesieniu do modelu siłowego samokontroli, ale psychologii i nauki w ogóle. Grupa naukowców pod przewodnictwem Briana Noska skupiona w organizacji Open Science Collaboration (OSC) opublikowała replikacje 100 badań eksperymentalnych i korelacyjnych (Open Science Collaboration, 2015). Czym jest replikacja? To ponowne przeprowadzenie badania przy zachowaniu (w możliwie najwierniej- 
szej formie) oryginalnej metody i jego przebiegu. Po co robić coś takiego? $\mathrm{Na}$ wynik każdego badania wpływa bardzo wiele zmiennych, takich jak procedura, zastosowane narzędzia i testy, osoby badane, a nawet sama osoba eksperymentatora. Ponadto określanie istotności statystycznej (na podstawie której decyduje się, czy faktycznie zachodzi różnica w wynikach pomiędzy grupami albo związek pomiędzy zmiennymi istnieje) polega na szacowaniu prawdopodobieństwa, a nie jednoznacznym stwierdzaniu, czy coś jest absolutną prawda, czy kompletnym fałszem. Zawsze istnieje prawdopodobieństwo, że otrzymany wynik nie odzwierciedla rzeczywistości. Zatem rezultaty takiego badania mogą być przypadkowe, dany wynik może być artefaktem - i niekoniecznie musi to świadczyć o nieprawidłowej procedurze czy braku profesjonalizmu przy jego przeprowadzaniu. Natomiast jeśli takie badanie zostanie powtórzone kilka razy, czyli zreplikowane właśnie, to szanse na to, że jego wynik był przypadkowy, znacznie spadaja. Niestety, badania nie są często replikowane, większość naukowców chce pokazać w swoim artykule coś nowatorskiego, a nie powtarzać pracę kolegów.

Dlatego właśnie naukowcy z OSC postanowili powtórzyć badania, które opublikowano w 2008 roku w prestiżowych czasopismach psychologicznych. Wyniki tych replikacji były zatrważajace - podczas gdy w oryginalnych badaniach istotne wyniki uzyskano w 97\% z nich, w replikacjach - tylko w 36\%. I tylko niecała połowa zreplikowanych sił efektów (miara tego, na ile duża jest różnica pomiędzy grupami albo jak silny zachodzi związek pomiędzy zmiennymi) była podobna do oryginalnych (OSC, 2015). Oczywiście nie oznacza to, iż wyniki, które udało się powtórzyć, są absolutnie prawdziwe, a te, których nie udało się zreplikować, nie są prawda. Ale cały projekt replikacyjny i jego rezultaty prowadzą do trudnego pytania: które badania w psychologii się replikują, a które nie? Innymi słowy, co jest dobrze udowodnione, które zjawiska psychologiczne czy teorie sa wiarygodne, a które niekoniecznie? Kryzys replikacyjny nie dotyczy tylko psychologii. Podobne problemy pojawiają się w wielu innych naukach (Begley, 2013; Camerer i in., 2016; Halperin, Vigotsky, Foster, Pyne, 2018; Hunter, 2001; Ioannidis, 2016).

Z czego to wynika? Jak to możliwe, że nie udaje się powtórzyć tylu wyników badań? Przyczyn, jak zwykle w tak złożonej kwestii, jest wiele - od używania nie do końca wiarygodnych metod badawczych, po niewłaściwe praktyki naukowców. Ale jedna z przyczyn prawdopodobnie ma największy wpływ na ten stan rzeczy - chodzi o tak zwaną tendencyjność w publikowaniu. Tendencyjnością w publikowaniu określa się zjawisko nierównych szans na publikację badania ze względu na jego wyniki (Franco, Malhotra, Simonovits, 
2014). Badania, w których uzyskano tzw. rezultat istotny statystycznie, maja wyższe szanse na publikację niż badania z nieistotnym wynikiem. To jest do pewnego stopnia zrozumiałe: ciekawszy jest artykul, w którym opisuje się, że np. jedna metoda leczenia okazała się lepsza od drugiej, jedna grupa ludzi jest pod jakimś względem różna od drugiej, czy że pomiędzy zmiennymi zachodzi związek, niż że takich różnic lub związków nie ma (na co wskazuje nieistotny wynik). Dlatego też czasopisma naukowe chętniej przyjmują takie istotne wyniki, ale i sami naukowcy chętniej je wysyłają do publikacji. A te badania, które nie wykazały różnic czy związków najczęściej nie są publikowane, zazwyczaj prawie nikt o nich nie wie, mówiąc metaforycznie chowa się je do szuflady i tę szufladę zamyka - dlatego ten problem określa się mianem efektu szuflady. To ma ogromne negatywne konsekwencje dla nauki. Wyobraźmy sobie, że przeprowadzono 100 badań nad jakimś zjawiskiem. Tylko w 5 badaniach uzyskano istotny efekt, co prawdopodobnie jest czystym przypadkiem. Tendencyjność publikacyjna sprawia, że tylko te 5 badań zostanie opublikowanych, a 95 zostanie schowanych do szuflady i nikt się o nich nie dowie. Przeczytamy zatem tylko o tych 5 badaniach i na tej podstawie uwierzymy, iż jakieś zjawisko zachodzi, podczas gdy całość danych dotyczących tego zjawiska wskazuje na zupełnie inny wniosek.

Wracając do siły woli, tendencyjność publikacyjna jest właśnie najważniejszym powodem, dlaczego nowe metaanalizy ukazały inne wyniki. Carter i współpracownicy (2015) oraz Carter i McCullough (2014) użyli nieco innych metod niż autorzy poprzedniej metaanalizy (Hagger i in., 2010). Po pierwsze, zastosowali ostrzejsze kryteria selekcji badań włączanych do metaanalizy. Po drugie, uwzględnili nieopublikowane badania, czyli „,sięgnęli do szuflady”, w której były one schowane (rozesłali wiadomości do badaczy zajmujących się wyczerpaniem ego z pytaniem, czy mają może nieopublikowane badania i czy mogliby je udostępnić). Po trzecie wreszcie, użyli kilku nowatorskich metod statystycznych, które szacują wpływ tendencyjności publikacyjnej na wyniki. Te zmiany właśnie przyniosły rezultaty sugerujące, że wyczerpanie ego jest albo bardzo słabym efektem, albo wręcz nie zachodzi.

Te metaanalizy były oczywiście krytykowane (Inzlicht, Gervais, Berkman, 2015). Postanowiono zatem podejść do tego problemu w jeszcze jeden sposób. Podstawowe pytanie dotyczące nie tylko modelu siłowego, ale psychologii i nauki brzmi - jak zaradzić tendencyjności publikacyjnej? Metodą na to jest tzw. prerejestracja - czyli rejestracja badania jeszcze przed jego przeprowadzeniem. Naukowcy opisuja podstawy teoretyczne danego badania, jego dokładną metodę oraz obliczenia statystyczne, jakie planują zrobić. Rejestracja jest następnie 
zapisywana na platformie online. Takie badanie nie ginie na wieki gdzieś w szufladzie - wiemy, niezależnie od ostatecznych wyników, że było przeprowadzane. Tą droga postanowił pójść autor pierwszej metaanalizy badań nad wyczerpaniem ego - Hagger i jego współpracownicy (2016). Projekt był potężny, zaangażowano 23 laboratoria z całego świata, przebadano w sumie 2141 osób. Uzgodniono metodę badania (we wszystkich laboratoriach identyczną) z eksperymentatorami zajmującymi się wyczerpaniem ego, włącznie z samym Royem Baumeisterem. Projekt zarejestrowano przed przeprowadzeniem. Jego rezultaty okazały się kolejnym silnym ciosem dla modelu siłowego - wyniki wskazywały, że wyczerpanie ego nie zachodzi. W tym samym roku opublikowano drugą, podobna pracę, również prerejestrowana $-z$ takimi samymi konkluzjami (Lurquin i in., 2016).

Jeśli tego byłoby mało, to podważono także jakikolwiek związek glukozy z samokontrola. Badania te były krytykowane od początku ze względu na niedokładną metodę przeprowadzenia oraz zbyt uproszczone założenia (por. Jędrzejczyk, Lewczuk, 2017). Replikacje wykazały, że ani poziom glukozy się nie zmniejszał po wykonaniu zadania wymagającego siły woli, ani jej zażycie nie podwyższało skuteczności, w żaden sposób nie wiązała się z poziomem wykonania zadania (Dang, 2016; Finley, Tang, Schmeichel, 2019). Nie potwierdzono także jakiegokolwiek wpływu treningu na samokontrolę (Inzlicht, Berkman, 2015; Miles i in., 2016).

Co to wszystko oznacza dla rozumienia mechanizmów siły woli? Nie można powiedzieć, że model siłowy został ostatecznie obalony, tak jak wcześniej nie można było stwierdzić, iż jest absolutna, niepodważalną prawda. Przez 20 lat był to dominujący sposób rozumienia samokontroli, zarówno w nauce, jak i w szerszym odbiorze. Jednak z czasem zaczęły pojawiać się badania nie do końca pasujące do założeń tej koncepcji, a w ostatnich latach ukazały się metaanalizy i prerejestrowane raporty replikacyjne, które są bardzo mocnymi argumentami przeciw temu modelowi. Wśród naukowców dyskusja nadal się toczy - niektórzy przytaczaja przekonujące argumenty, iż to skrajnie mało prawdopodobne, by wyczerpanie ego nie zachodziło (Friese, Loschelder, Gieseler, Frankenbach, Inzlicht, 2018). Część osób postuluje, że ten temat powinno się zostawić i nie poświęcać na niego więcej zasobów badawczych, część, że potrzebne są kolejne replikacje, jeszcze inni wskazują na potrzebę nowych metod badania modelu siłowego, szczególnie w warunkach naturalnych - poza laboratorium (przegląd opinii w: Inzlicht, Friese, 2019). W każdym razie historia modelu Baumeistera pokazuje nie tylko to, jak do tej pory rozumieliśmy siłę woli, ale ilustruje także działanie nauki, zarówno jej błędów i niedoskonałości, 
jak i potencjału naprawy samej siebie. Pozostaje jeszcze kluczowe pytanie - to jak zatem działa siła woli?

\section{SIŁA WOLI JAKO DECYZJA}

Gdy pojawiało się coraz więcej badań nie pasujących do modelu siłowego, np. te wskazujące, że odpowiednia motywacja (Muraven, Slessareva, 2003) czy przekonania o sile woli (Job i in., 2010) mogą zapobiegać wyczerpaniu ego, naukowcy zaczęli zastanawiać się nad alternatywnymi wyjaśnieniami fenomenu samokontroli. Interesujące jest to, że nowe modele powstały jako próby alternatywnego ujęcia efektu wyczerpania ego, ale jeśli nawet by się okazało, iż wyczerpanie ego w ogóle nie zachodzi (co sugerują badania przytoczone w poprzednim rozdziale), to te koncepcje nadal moga być trafne, ponieważ odnoszą się do jeszcze szerszego zjawiska - zmęczenia mentalnego. Badania nad wyczerpaniem ego były ciekawe m.in. dlatego, że pokazywały naprawdę szybkie wyczerpywanie się naszego ego - zadania trwały czasami zaledwie kilka minut i już wpływały na gorsze wykonanie kolejnej czynności. Natomiast samo zmęczenie bada się zwykle dłużej: kilkadziesiąt minut, godzinę, czasami wiele godzin i jego wpływ na nasze gorsze funkcjonowanie był wielokrotnie udowadniany (Dai, Milkman, Hofmann, Staats, 2014; Hockey, 2011). Jednocześnie to, iż trudniej nam działać, gdy jesteśmy zmęczeni po wielu godzinach pracy, jest tak oczywiste, że czasami pojawiają się wątpliwości, czy jest sens w ogóle to badać (Inzlicht, Friese, 2019). Nowe koncepcje dotyczą zatem szerszej klasy zjawisk niż tylko wyczerpanie ego.

Nad zmęczeniem i poczuciem wysiłku zastanawiali się Kurzban, Duckworth, Kable i Myers (2013) i to był punkt wyjścia do nowego modelu. Wysiłek jest trudny, także emocjonalnie, ponieważ gdy czujemy, że coś wymaga od nas dużego nakładu pracy, często tego unikamy, wykonywanie takiej czynności jest nieprzyjemne, awersyjne (Inzlicht, Shenhav, Olivola, 2017). Gdy trudno zabrać się nam za jakąś pracę, może to być spowodowane właśnie tym, że przewidujemy, że będzie wiązała się z wysiłkiem, tzn., że trzeba będzie się mocno skupić, pracować wytrwale a sama praca może być nudna.

To jest trochę paradoks. Zazwyczaj wysiłek prowadzi nas do osiagania długoterminowych celów. Oglądanie seriali może i jest przyjemne, ale to praca, często wymagająca, wiąże się z satysfakcją, sięganiem po dalekie cele, czy wręcz możliwością utrzymania się. Zatem opłaca się wkładać wysiłek w różne rzeczy, choć jednocześnie jest on nieprzyjemny. Dlaczego nasz umysł tak działa? Czy nie lepiej by było, gdyby ewolucja nas przystosowała do rzeczywistości w taki 
sposób, że wysiłek jest przyjemny, dzięki temu lepiej dbamy o długoterminowe efekty (zdrowotne, socjoekonomiczne czy jakiekolwiek inne)?

Kurzban i in. (2013) tłumaczą tę niespójność jednym z podstawowych wyzwań, jakie niesie ze sobą życie. Nie mamy jednego jedynego celu w życiu, w który moglibyśmy zainwestować cały wysiłek. Każdy z nas ma tych celów wiele. Z jednej strony może zależeć nam na robieniu kariery (którą również można realizować na wiele sposobów), ale istotne jest także dbanie o relacje - zarówno o te rodzinne, jak i przyjacielskie. Potrzebne jest też zadbanie o zdrowie, odpoczynek, przyjemność, rozwijanie swoich pasji i tym podobne. Nie da się o te wszystkie potrzeby dbać jednocześnie. Jak sobie z tym radzimy? Ustalamy priorytety. Najpierw zabieramy się za jeden cel, z czasem zmieniamy aktywność - dbamy o inną potrzebę, potem kolejną, później wracamy do tej pierwszej i tak cały czas.

Zaproponowany przez powyższych autorów model kosztu alternatywnego uznaje problem wielu celów i jego rozwiązanie, priorytetyzację, za fundamentalny dla zrozumienia siły woli. Skoro mamy wiele zadań do wykonania, musimy wiedzieć, kiedy zakończyć jedno, by zabrać się za drugie.

Badacze wskazuja, że umysł nieustannie przetwarza informacje i na podstawie tych informacji podejmuje decyzje prowadzące nas do określonych zachowań. Możemy ważyć różne dylematy: gdzie pojechać na urlop? Góry czy morze? Co będzie przyjemniejsze - chodzenie po górach czy leżenie na plaży? Jakie są ceny poszczególnych opcji? Co ciekawego może być do zobaczenia w każdym z tych miejsc? W ten sposób gromadzimy różne za i przeciw każdej opcji, aż w końcu któraś przeważy. Przy różnych czynnościach wymagających samokontroli, wedle modelu kosztu alternatywnego, działa to podobnie, tylko raczej na poziomie nieświadomym: nasz umysł nieustannie waży, czy to, co robimy, jest najlepszą decyzją, czy może korzystniejsze byłoby zrobienie czegoś innego. Im bardziej rośnie wartość innej rzeczy, którą moglibyśmy robić, tym bardziej rośnie koszt alternatywny (czyli utracone korzyści, które byśmy odnieśli, gdybyśmy wykonywali tę drugą rzecz) obecnej czynności. Jeśli jakiś czas pracujemy w skupieniu, na przykład pisząc tekst, i dojrzymy telefon leżący niedaleko - możemy sobie pomyśleć, iż ciekawie byłoby sprawdzić, czy ktoś napisał do nas wiadomość albo co zamieszczono w mediach społecznościowych. W tym momencie rośnie koszt alternatywny naszej pracy - umysł zaczyna szacować korzyści z zajrzenia do telefonu jako większe niż te wynikające z pracy nad tekstem. Sygnałem, że ten koszt alternatywny urósł, jest właśnie poczucie wysiłku czy zmęczenia - tym bardziej dojmujące, im wyższy 
jest koszt alternatywny (czyli im bardziej zachęcająca wydaje się nam ta druga, alternatywna czynność).

Zatem, o ile w modelu siłowym Baumeistera zmęczenie czy poczucie wysiłku i związana z tym trudność w wykonywaniu zadań miały być wynikiem wyczerpania zasobu, w modelu kosztu alternatywnego postrzega się to inaczej. Poczucie wysiłku wynika z tego, że alternatywna czynność, którą moglibyśmy wykonywać, zaczyna być bardziej wartościowa niż to, co robimy w danym momencie. Kurzban i in. (2013) również sugerują, że nasze zasoby są ograniczone, ale nie jako paliwo, które się zupełnie wyczerpuje, tylko raczej jako pewna pula, która jednocześnie może zajmować się ograniczoną liczbą procesów. Autorzy porównują to do pracy komputera i jego mocy obliczeniowej: po kilku wykonanych zadaniach moc obliczeniowa się nie wyczerpuje, ale jednak komputer nie może wykonywać nieskończonej liczby zadań na raz. Innym przykładem jest nasza uwaga. O ile jesteśmy świadomi - zawsze jest gdzieś skierowana, o czymś myślimy, nad czymś się skupiamy, coś dostrzegamy, ale nie da się skierować uwagi na wszystko jednocześnie. Dlatego też, skoro ta pula jest ograniczona, a my mamy wiele celów, musimy dbać o różne potrzeby. Pojawia się uczucie wysiłku i trudność w kontynuowaniu danego zadania - jest to informacja, że być może warto zająć się innym celem. Im więcej wysiłku czujemy, tym trudniej nam się zmuszać, więc w końcu nasza samokontrola odpuszcza i przerywamy aktywność.

Bardzo podobnie do siły woli podchodzą Berkman, Hutcherson, Livingston, Kahn i Inzlicht (2017), którzy proponują by samokontrolę uznać za rodzaj wyboru opartego na wartościowaniu. Sugerują oni, że gdy mamy cel i jednocześnie natykamy się na jakąś alternatywę wobec niego (praca vs. odpoczynek, dieta vs. słodycze itp.), nasz umysł zaczyna ważyć poszczególne opcje - wszelkie za i przeciw. W grę wchodzi wiele czynników, nie tylko przyjemność i zysk długoterminowy, ale też akceptacja społeczna danego wyboru, ewentualne zyski finansowe, ilość wysiłku, jakiej wymaga każda z opcji, koszty alternatywne i inne. Autorzy podkreślają, iż na wartość poszczególnych opcji wpływają także pewne nasze błędy poznawcze, np. niedocenianie odroczonych zysków (zyski, które otrzymamy za pewien czas, wydają się nam mniej wartościowe niż te, które możemy mieć wcześniej; Kahneman, Knetsch, Thaler, 1991). Ważenie poszczególnych opcji nie jest operacją czysto analityczną i racjonalną - jest tu także pewna doza przypadkowości, ponieważ nasza uwaga ciagle się zmienia, raz się skupia na jednej opcji, raz na drugiej, na poszczególnych za i przeciw, co odzwierciedla działanie naszego mózgu, w tym przypadkowe wyładowania neuronalne. Zatem, przy dokładnie tych samych warunkach, powtórny wybór 
opcji mógłby być inny niż wcześniej z powodu czystego przypadku (ponieważ akurat przyszło nam jakieś przypadkowe wspomnienie do głowy, czy przekierowaliśmy uwage na coś innego, czy po prostu nastapiły losowe wyładowania neuronów w naszej głowie).

Z kolei Inzlicht, Schmeichel i Macrae (2014), by wytłumaczyć fenomen samokontroli w swoim modelu zmiany priorytetów, sięgają do podstaw ewolucyjnych. Większość istot żywych staje przed dylematem eksploatacja vs eksploracja, tj. czy eksploatować jakieś źródło zasobów (najczęściej pożywienia), czy poszukiwać nowych źródeł, czyli eksplorować. Pomiędzy tymi dwoma strategiami potrzebna jest równowaga, skupienie się tylko na jednej z nich nie jest korzystne. Jeśli zwierzę będzie tylko i wyłącznie eksploatować jedno źródło - może być to coraz trudniejsze, a czasem to źródło może się zupełnie wyczerpać i nie będzie alternatywy. Z drugiej strony, jeśli jakiś organizm będzie tylko i wyłącznie eksplorował - nie wykorzysta z pewnego i bezpiecznego źródła, lecz będzie się nieustannie narażał na poszukiwanie czegoś nowego, co jest ryzykowne. Autorzy przekładaja te fundamentalne motywacje na nasze ludzkie cele typu „muszę” i cele typu „chcę”. Cele „muszę” to odpowiednik eksploatacji - coś, co jest związane z motywacją zewnętrzną (nagrodami, pieniędzmi, obowiazzkami). Cele „chcę” odpowiadają eksploracji, zwiazzane są z motywacja wewnętrzna, czyli aktywnością, która sama w sobie sprawia nam przyjemność. W momencie gdy przez dłuższy moment jakąś czynność „eksploatujemy”, czyli wykonujemy ja, mimo że nie sprawia nam wielkiej przyjemności, to powoli szala w naszym umyśle zaczyna się przesuwać w kierunku „eksploracji” - czegoś przyjemnego. Czynniki zewnętrzne (bodźce w środowisku) i wewnętrzne (myśli, emocje) wpływają na tę równowagę i mogą ukierunkowywać naszą motywację albo na cel „muszę”, albo na cel „chcę”. Gdy się zmienia motywacja, również nasza percepcja, pamięć czy uwaga ulega zmianie. Jeśli na przykład podczas pracy poczujemy się zmęczeni, może się nam przypomnieć ostatni raz, kiedy się głęboko zrelaksowaliśmy, zaczniemy zauważać elementy naszego otoczenia związane z odpoczynkiem, a z pola uwagi zupełnie zniknie cel, który nam przyświecał, gdy rozpoczynaliśmy pracę.

Co łączy wszystkie te modele? Po pierwsze, rezygnują z pojęcia szybko wyczerpywalnych zasobów. Owszem, postulują one, że jesteśmy w jakiś sposób ograniczeni, ale nie tak, iż kończy się nam paliwo i nie jesteśmy w stanie nic zrobić, tylko tak, że nie możemy się zajmować wszystkim na raz i w związku z tym musimy decydować (mniej lub bardziej świadomie), co jest priorytetem. Stawiają one założenie, że mamy tendencję do zachowywania równowagi pomiędzy dążeniem do różnych celów (w tym celów „chcę”). Po drugie, nie 
ograniczają się tylko i wyłącznie do fenomenu wyczerpania ego - krótkotrwałej trudności w użyciu siły woli po tym, jak ją chwilę wcześniej wykorzystaliśmy - ale biorą pod uwagę szersze pojęcia, takie jak zmęczenie w ogóle czy poczucie wysiłku, które czasami pojawia się szybko (jak wyczerpanie ego), a czasami po dłuższym czasie. Niektórzy wręcz sugerują, iż wyczerpanie ego jest specjalnym, krótkoterminowym przypadkiem zmęczenia (Inzlicht i in., 2014). To istotna teza, ponieważ biorąc pod uwagę kontrowersje dotyczące modelu siłowego przedstawione w poprzednim rozdziale, nawet gdyby się okazało, że wyczerpanie ego nie zachodzi, te nowsze modele nadal trafnie moga wyjaśniać nasze zachowanie. Po trzecie, wszystkie podchodzą do siły woli jako do decyzji. To już nie chodzi o kończący się zasób samokontroli i bezbronność wobec tego faktu. Wraz z wysiłkiem i stosowaniem samokontroli - co jest wymagające i nieprzyjemne - zniechęcamy się do danego zadania. Obniża się nam motywacja, czy raczej pojawia się inna - skłaniająca do zajęcia się czymś innym, np. odpoczynkiem.

Jak zatem wzmacniać swoją siłę woli, opierając się na założeniach powyższych modeli? Model Baumeistera proponował trening, oszczędzanie zasobu, ewentualnie glukozę. Tutaj sprawa wygląda zgoła inaczej. Wszystkie trzy modele wskazują, iż to, na ile skutecznie uda nam się użyć samokontroli i działać na rzecz celu długoterminowego, zależy od oceny dostępnych opcji. Zazwyczaj wygląda to tak, że wysiłek oceniamy jako nieprzyjemny, więc go unikamy, a chętnie zabieramy się za ciekawsze czynności, typu oglądanie serialu, zaglądanie na media społecznościowe czy jedzenie z wysoką zawartością cukru i tłuszczu. Co by było, gdybyśmy jednak zmienili tę ocenę? Na tym właśnie polega wzmacnianie siły woli według tych modeli - na nadawaniu większej wagi tej opcji, którą uznajemy dla nas za korzystniejsza.

Jedno z badań, które podważało model siłowy, wskazywało, jak ważną rolę gra motywacja (Muraven, Slessareva, 2003), tzn. badanych przekonywano, że udział w eksperymencie ma doniosłe znaczenie albo ich nagradzano. Zatem żeby wzmocnić tę opcję, na której nam zależy, może warto pomyśleć, co ważnego stoi za tym działaniem. Do czego nas ono doprowadzi? Jakie będa dalekosiężne zyski z jego wykonania? Można także pomyśleć o nagradzaniu się za część wykonanego zadania. To sprawi, że poczujemy przyjemność związana z praca, a to osłabia poczucie wysiłku (Kurzban i in., 2013). Być może są inne sposoby uczynienia bardziej przyjemnym zachowania, na którym nam zależy? Z drugiej strony, warto pomyśleć nad osłabieniem drugiej opcji, czyli pokus. Jednym sposobem jest zastanowienie się, jakie będą długoterminowe konsekwencje wyboru tej opcji. Jak będzie wyglądało nasze życie, gdy co chwila 
będziemy sprawdzali media społecznościowe? Sięgali po niezdrowe jedzenie? Taka wizja nie budzi entuzjazmu, więc może obniżyć wartość tego wyboru. Znaczenie ma to, jak kierujemy swoją uwagą - jeśli coś jest tuż przy nas, np. telefon z dostępem do Internetu - wartość czynności pt. „zajrzenie do telefonu" będzie rosła. Zaś utrudnienie sobie dostępu do różnych pokus będzie się wiązało z wysiłkiem, jaki musimy włożyć, by po pokusę sięgnać, a zatem obniży wartość wyboru pokusy. Znaczenie mogą mieć nasze przekonania: gdy wierzymy, iż coś jest stosunkowo łatwe do zrobienia, to taka wiara sprawi, że dana opcja będzie atrakcyjniejsza niż coś trudnego. Przypomnienie sobie sytuacji, gdy podobne działanie nam wychodziło, może wzmocnić taką postawę. Jeśli z kolei wierzymy, iż mamy szybko wyczerpującą się siłę woli, to łatwiej zauważymy u siebie oznaki zmęczenia (Job, Bernecker, Miketta, Friese, 2015) i trudniej nam będzie wytrwać w wymagającej pracy.

W modelach traktujących samokontrolę jako proces decyzyjny optymistyczne jest to, że dają nam znacznie większe pole manewru niż model siłowy. Powyższe metody wzmacniania siły woli to tylko część przykładów. Ogólny mechanizm polega na wartościowaniu opcji, a to, w jaki sposób zwiększymy wartość tej, na której nam zależy i obniżymy tej, której nie chcemy ulec, zależy już od nas i naszej pomysłowości. Istnieje wiele możliwości, jak to zrobić (Jędrzejczyk, Huflejt-Łukasik, 2017). Jest jeszcze jedno ciekawe założenie, które implikują modele decyzyjne: czasami możliwe jest bardzo znaczące przeważanie istotnego dla nas wyboru - tak, że działanie na jego rzecz stanie się przyjemne samo w sobie $\mathrm{i}$ wtedy w ogóle samokontrola nie będzie nam potrzebna. Wiele z nas zapewne doświadczyło kiedyś „zapomnienia się” w pracy - stała się ona tak wciagająca, mimo że cały czas wymagająca, iż przestaliśmy zauważać upływ czasu, absolutnie nie musieliśmy się do niczego zmuszać i trwało to godzinami.

Minusem modeli decyzyjnych jest to, że są to dość nowe propozycje i badania bezpośrednio je weryfikujące dopiero się rozpoczynają. Choć, jak zostało wspomniane wcześniej, pasują do dotychczasowych zjawisk - zarówno wyczerpania ego, jak i zmęczenia czy poczucia wysiłku. Oczywiście są również krytykowane przez zwolenników modelu siłowego (Baumeister, Vohs, 2016).

Jak nowe modele samokontroli odnoszą się do procesów dualnych, systemu refleksyjnego i systemu impulsywnego? Berkman i in. (2017) postulują, że skoro siła woli jest decyzją opartą na wartości, to nie ma sensu wyjaśniać jej mechanizmów za pomoca procesów dualnych. Shenhav (2017) z kolei wskazuje, iż to zbytnie uproszczenie i jak najbardziej rozumienie siły woli jako procesu decyzyjnego łączy się z systemem refleksyjnym i impulsywnym. Sugeruje on na 
przykład, że to, jak szacujemy poszczególne opcje do wyboru, w ogromnym stopniu zależy od uwagi, którą im poświęcamy. A uwagą możemy kierować impulsywnie, nieświadomie, np. gdy coś przyciaga nasz wzrok (telefon leżący nieopodal) albo nasz stan organizmu wyczula nas na pewne bodźce (np. głód na jedzenie), ale też świadomie, używając naszych funkcji wykonawczych (np. możemy się skupić na myślach dotyczących naszego celu długoterminowego). Zatem modele procesów dualnych mogą być szerszym kontekstem teoretycznym nowszych koncepcji siły woli oraz je dopełniać. W takim ujęciu warto by się zastanowić, jak system refleksyjny może wzmocnić jedną opcję wyboru (chociażby właśnie przez utrzymywanie celu długoterminowego w pamięci roboczej). Z drugiej strony, system impulsywny jest związany z pokusami, celami „chcę”, można więc opracować sposób, by go osłabić, np. poprzez utrudnianie sobie dostępu do pokus czy usunięcie ich z pola widzenia, aby nie wzbudzał się tak łatwo.

\section{PODSUMOWANIE}

Na pytanie, jak to się dzieje, że chcemy coś robić, wiemy, jak to zrobić, mamy ku temu wszelkie możliwości, a jednak tego nie robimy - poszukuje się odpowiedzi od wielu lat. Ta kwestia zainteresowała psychologów, którzy próbowali wyjaśnić to zagadnienie, badając coś, co nazywają samokontrolą, a co potocznie określa się siłą woli. Jedną z pierwszych kompleksowych prób zbadania tego fenomenu są eksperymenty nad odroczona gratyfikacją u dzieci autorstwa Waltera Mischela i jego wspólpracowników. Mischel zauważył, iż istnieje szereg czynników, które wpływają na to, czy dzieci są w stanie odroczyć nagrodę (czyli innymi słowy - zastosować samokontrolę). Te czynniki to m.in. odwracanie uwagi czy abstrakcyjny sposób myślenia o pokusie. Mischel na podstawie tych obserwacji zaproponował teorię, która dzieliła funkcjonowanie naszego umysłu na dwa systemy. Koncepcja Mischela jest jedną z propozycji, która należy do szerszej kategorii modeli procesów dualnych, opisujących pewne paradoksy w naszym funkcjonowaniu - to, że czasami podejmujemy racjonalne decyzje i kierujemy się intelektem, a czasami żądzą nami emocje, impulsy. Co pokazuje, jak znacząca rolę odgrywają w rozumieniu siły woli poznawcze funkcje wykonawcze oraz związana $z$ jedna $z$ nich inteligencja.

Przez ostatnie 20 lat badania Mischela zostały odłożone nieco na bok, a tematykę samokontroli zdominował model siłowy Roya Baumeistera. Model ten postulował proste, eleganckie wyjaśnienie działania siły woli, porównując ją do mięśnia, który potrzebuje energii, by działać. Gdy ta energia się wyczerpie, 
doświadczamy tzw. wyczerpania ego, stanu, w którym zastosowanie siły woli jest trudne lub wręcz niemożliwe. System refleksyjny, nasze funkcje intelektualne, w szczególności powstrzymywanie się od niechcianych reakcji, miałyby zatem opierać się na szybko wyczerpującym się zasobie, najpewniej glukozie, jak sugerowali zwolennicy modelu Baumeistera. Zaczęły się jednak pojawiać badania, które przeczyły założeniom modelu siłowego, a badaczom nie udało się powtórzyć efektów otrzymywanych przez Baumeistera.

Jednocześnie zaczęły pojawiać się alternatywne wyjaśnienia fenomenu samokontroli. Model kosztu alternatywnego, koncepcja siły woli jako decyzji opartej na wartościowaniu czy model zmiany priorytetów łączy to, iż traktują samokontrolę jako proces decyzyjny. Nasz umysł waży różne opcje, najczęściej jedna związaną z celem długoterminowym, drugą związaną z czymś, co szybko potrafi nam sprawić przyjemność (choć czasami z innym celem długoterminowym) i wybiera to, co w danym momencie ocenia jako bardziej wartościowe - a za tym idzie nasze zachowanie, czyli albo ulegnięcie pokusie, albo wykonywanie trudniejszej, ale korzystnej w długiej perspektywie czynności. W tych modelach nie ma miejsca na szybko wyczerpujący się zasób, fundamentalne miejsce zajmuje zaś motywacja - jeśli jesteśmy w stanie nią odpowiednio pokierować, możemy wytrwać w działaniu, które jest wymagające. Te koncepcje można również odnieść do idei podziału naszego funkcjonowania na system refleksyjny i impulsywny: wykorzystanie pierwszego i obejście drugiego może przyczynić się do takiego wartościowania poszczególnych wyborów, na jakim nam zależy.

Co ciekawe, do nowszych modeli siły woli można odnieść klasyczne badania Mischela. I w jednej, i w drugiej koncepcji ma miejsce dość duże skupienie się na procesach, które przyczyniają się do takich, a nie innych decyzji czy zachowań. Jednocześnie tych procesów wpływających na końcowy rezultat jest wiele, co z kolei sprawia, że możemy na różne sposoby, od różnych stron wpływać na naszą siłę woli. W tym kontekście model siłowy zdaje się nieco bardziej pesymistyczny - uznając go, pole działania mamy niewielkie: możemy się oszczędzać albo trenować mięsień siły woli. Jest to może zatem plus, że dotychczasowe badania nad samokontrola potoczyły się w ten sposób i nowe modele postulują, że za siłą woli stoją bardziej dynamiczne procesy, podobnie jak we wczesnych propozycjach Mischela. Znacząca rolę odgrywa tutaj system refleksyjny oparty na poznawczych funkcjach wykonawczych: aktualizowaniu, hamowaniu i przełączaniu. Dzięki nim możemy wpływać na nasze zachowanie, myślenie i emocje. Tym samym, do pewnego stopnia kierować tymi dynamicznymi procesami, które stoją za siłą woli. Wiele pytań pozostaje jednak jeszcze 
bez odpowiedzi. Mimo że przedstawiono pewne propozycje, to nie do końca wiadomo, jak koncepcja systemu refleksyjnego odnosi się do nowych sposobów rozumienia siły woli. Skoro siła woli działa raczej jak proces decyzyjny, to jakie role mają do odegrania w tym procesie system refleksyjny i system impulsywny? Które funkcje wykonawcze są kluczowe podczas codziennych sytuacji wymagających samokontroli? Czy to hamowanie, którego definicja jest zbieżna z definicją samokontroli, czy może aktualizowanie, oparte na pamięci roboczej, która umożliwia np. myślenie o długoterminowych konsekwencjach każdego z wyborów? Te kwestie wymagają dalszych badań.

Jak wcześniej wspomniano, jedna z funkcji wykonawczych, aktualizowanie, jest silnie związana z inteligencją. Pokazuje to, jak duże znaczenie ma inteligencja w życiu codziennym, w podejmowaniu prozaicznych wyborów i dążeniu do celów długoterminowych. W badaniach nad siłą woli dość rzadko odwoływano się do inteligencji, zazwyczaj nie mierzono jej w eksperymentach. To również jest interesujący wątek do poruszenia w przyszłych badaniach.

\section{BIBLIOGRAFIA}

Baumeister, R. F., Bratslavsky, E., Muraven, M., Tice, D. M. (1998). Ego depletion: Is the active self a limited resource? Journal of Personality and Social Psychology, 74(5), 1252-1265. https://doi.org/10.1037/0022-3514.74.5.1252

Baumeister, R. F., Vohs, K. D. (2016). Strength model of self-regulation as limited resource: Assessment, controversies, update. W: J. M. Olson, M. P. Zanna (red.), Advances in experimental social psychology, t. 54 (s. 67-127). San Diego: Elsevier Academic Press. https://doi.org/10.1016/bs.aesp.2016.04.001

Baumeister, R. F., Vohs, K. D., Tice, D. M. (2007). The strength model of self-control. Current Directions in Psychological Science, 16, 351-355. https://doi.org/10.1111/ j.1467-8721.2007.00534.x

Begley, C. (2013). Six red flags for suspect work. Nature, 497(7450), 433-434. https:// doi.org/10.1038/497433a

Berkman, E., Hutcherson, C., Livingston, J., Kahn, L., Inzlicht, M. (2017). Self-control as value-based choice. Current Directions in Psychological Science, 26(5), 422-428. https://doi.org/10.1177/0963721417704394

Bernecker, K., Job, V. (2015). Beliefs about willpower moderate the effect of previous day demands on next day's expectations and effective goal striving. Frontiers in Psychology, 6, 1496. https://doi.org/10.3389/fpsyg.2015.01496 
Boksem, M., Meijman, T., Lorist, M. (2006). Mental fatigue, motivation and action monitoring. Biological Psychology, 72(2), 123-132. https://doi.org/10.1016/j. biopsycho.2005.08.007

Camerer, C., Dreber, A., Forsell, E., Ho, T., Huber, J., Johannesson, M., ..., Wu, H. (2016). Evaluating replicability of laboratory experiments in economics. Science, 351(6280), 1433-1436. https://doi.org/10.1126/science.aaf0918

Carter, E. C., Kofler, L., Forster, D., McCullough, M. (2015). A series of meta-analytic tests of the depletion effect: Self-control does not seem to rely on a limited resource. Journal of Experimental Psychology: General, 144(4), 796-815. https://doi. org/10.1037/xge0000083

Carter, E. C., McCullough, M. E. (2014). Publication bias and the limited strength model of self-control: Has the evidence for ego depletion been overestimated? Frontiers in Psychology, 5, 823. https://doi.org/10.3389/fpsyg.2014.00823

Dai, H., Milkman, K. L., Hofmann, D. A., Staats, B. R. (2014). The impact of time at work and time off from work on rule compliance: The case of hand hygiene in health care. The Journal of Applied Psychology, 100, 846-862. https://doi. org/10.1037/a0038067

Dang, J. (2016). Testing the role of glucose in self-control: A meta-analysis. Appetite, 107, 222-230. https://doi.org/10.1016/j.appet.2016.07.021

Deary, I. J. (2012). Intelligence. Annual Review of Psychology, 63, 453-482. https://doi. org/10.1146/annurev-psych-120710-100353

Derrick, J. (2013). Energized by television. Social Psychological and Personality Science, 4(3), 299-307. https://doi.org/10.1177/1948550612454889

Epstein, S. (1990). Cognitive-experiential self-theory. W: L. A. Pervin (red.), Handbook of personality. Theory and research (s. 165-192). Nowy Jork: Guilford.

Finley, A. J., Tang, D., Schmeichel, B. J. (2019). Sweet nothings: No effects of self-control exertion on blood glucose levels. Social Psychology, 50, 322-331. https://doi. org/10.1027/1864-9335/a000376

Franco, A., Malhotra, N., Simonovits, G. (2014). Publication bias in the social sciences: Unlocking the file drawer. Science, 345(6203), 1502-1505. https://doi. org/10.1126/science. 1255484

Freud, S. (2009). Wyktady ze wstęu do psychoanalizy. Nowy cykl. Warszawa: Wydawnictwo KR.

Friedman, N., Miyake, A., Corley, R., Young, S., DeFries, J., Hewitt, J. (2006). Not all executive functions are related to intelligence. Psychological Science, 17(2), 172-179. https:// doi.org/10.1111/j.1467-9280.2006.01681.x 
Friese, M., Loschelder, D., Gieseler, K., Frankenbach, J., Inzlicht, M. (2018). Is ego depletion real? An analysis of arguments. Personality and Social Psychology Review, 23(2), 107-131. https://doi.org/10.1177/1088868318762183

Gailliot, M. T., Baumeister, R. F. (2007). The physiology of willpower: Linking blood glucose to self-control. Personality and Social Psychology Review, 11, 303-327. https:/ / doi.org/10.1177/1088868307303030

Gailliot, M. T., Baumeister, R. F., DeWall, C., Maner, J., Plant, E., Tice, D. M., Schmeichel, B. J. (2007). Self-control relies on glucose as a limited energy source: Willpower is more than a metaphor. Journal of Personality and Social Psychology, 92, 325336. https://doi.org/10.1037/0022-3514.92.2.325

Gottfredson, L. (1997). Mainstream science on intelligence: An editorial with 52 signatories, history, and bibliography. Intelligence, 24(1), 13-23. https://doi.org/10.1016/ S0160-2896(97)90011-8

Hagger, M. S., Wood, C., Stiff, C., Chatzisarantis, N. (2010). Ego depletion and the strength model of self-control: A meta-analysis. Psychological Bulletin, 136(4), 495525. https://doi.org/10.1037/a0019486

Hagger, M. S., Chatzisarantis, N. L. D., Alberts, H., Anggono, C. O., Batailler, C., Birt, A., ..., Zwienenberg, M. (2016). A multi-lab pre-registered replication of the ego-depletion effect. Perspectives on Psychological Science, 11(4), 546-573. https://doi. org/10.1177/1745691616652873

Halperin, I., Vigotsky, A., Foster, C., Pyne, D. (2018). Strengthening the practice of exercise and sport-science research. International Journal of Sports Physiology and Performance, 13(2), 127-134. https://doi.org/10.1123/ijspp.2017-0322

Heckman, B., Ditre, J., Brandon, T. (2012). The restorative effects of smoking upon self-control resources: A negative reinforcement pathway. Journal of Abnormal Psychology, 121(1), 244-249. https://doi.org/10.1037/a0023032

Hockey, G. R. J. (2011). A motivational control theory of cognitive fatigue. W: P. L. Ackerman (red.), Cognitive fatigue: Multidisciplinary perspectives on current research and future applications (s. 167-188). Waszyngton: American Psychological Association.

Hofmann, W., Friese, M., Strack, F. (2009). Impulse and self-control from a dual-systems perspective. Perspective on Psychological Science, 4(2), 162-176. https://doi. org/10.1111/j.1745-6924.2009.01116.x

Hofmann, W., Schmeichel, B. J., Baddeley, A. D. (2012). Executive functions and self-regulation. Trends in Cognitive Sciences, 16, 174-180. https://doi.org/10.1016/j. tics.2012.01.006

Hunter, J. (2001). The desperate need for replications. Journal of Consumer Research, 28(1), 149-158. https://doi.org/10.1086/321953 
Inzlicht, M., Friese, M. (2019). The past, present, and future of ego depletion. Social Psychology, 50(5-6), 370-378. https://doi.org/10.1027/1864-9335/a000398

Inzlicht, M., Berkman, E. (2015). Six questions for the resource model of control (and some answers). Social and Personality Psychology Compass, 9(10), 511-524. https://doi. org/10.1111/spc3.12200

Inzlicht, M., Gervais, W., Berkman, E. (2015). Bias-correction techniques alone cannot determine whether ego depletion is different from zero: Commentary on Carter, Kofler, Forster, \& McCullough, 2015. Pobrane z: https://papers.ssrn.com/sol3/papers.cfm?abstract_id=2659409. http://dx.doi.org/10.2139/ssrn.2659409

Inzlicht, M., Schmeichel, B. J., Macrae, C. N. (2014). Why self-control seems (but may not be) limited. Trends in Cognitive Sciences, 18(3), 127-133. https://doi. org/10.1016/j.tics.2013.12.009

Inzlicht, M., Shenhav, A., Olivola, C. (2017). The effort paradox: Effort is both costly and valued. Trends in Cognitive Sciences, 4, 337-349. https://doi.org/10.1016/j. tics.2018.01.007

Ioannidis, J. (2016). Why most clinical research is not useful. PLOS Medicine, 13(6), e1002049. https://doi.org/10.1371/journal.pmed.1002049

Jędrzejczyk, J., Huflejt-Łukasik, M. (2017). Siła woli - modele teoretyczne i ich zastosowanie w coachingu. Coaching Review, 9(1), 8-23. https://doi.org/10.7206/ cr.2081-7029.45

Jędrzejczyk, J., Lewczuk, K. (2017). Wyczerpanie ego, glukoza i kryzys replikacyjny: 20 lat zasobowego modelu samokontroli. Psychologia-Etologia-Genetyka, 35, 25-44.

Jędrzejczyk, J., Zajenkowski, M. (2018). Who believes in nonlimited willpower? In search of correlates of implicit theories of self-control. Psychological Reports, 123(2), 281-299. https://doi.org/10.1177/0033294118809936

Job, V., Bernecker, K., Miketta, S., Friese, M. (2015). Implicit theories about willpower predict the activation of a rest goal following self-control exertion. Journal of Personality and Social Psychology, 109(4), 694-706. https://doi.org/10.1037/ pspp0000042

Job, V., Dweck, C. S., Walton, G. M. (2010). Ego depletion - Is it all in your head? Implicit theories about willpower affect self-regulation. Psychological Science, 21, 1686-1693. https://doi.org/10.1177/0956797610384745

Kahneman, D. (2012). Pułapki myślenia. O myśleniu szybkim i wolnym. Poznań: Media Rodzina.

Kahneman, D., Knetsch, J. L., Thaler, R. H. (1991). Anomalies: The endowment effect, loss aversion, and status quo bias. The Journal of Economic Perspectives, 5(1), 193-206. https://doi.org/10.1257/jep.5.1.193 
Kurzban, R., Duckworth, A., Kable, J., Myers, J. (2013). An opportunity cost model of subjective effort and task performance. Behavioral and Brain Sciences, 36(6), 661-679. https://doi.org/10.1017/S0140525X12003196

Kyllonen, P. C. (1996). Is working memory capacity Spearman's g? W: I. Dennis, P. Tapsfield (red.), Human abilities: Their nature and measurement (s. 49-75). Mahwah: Erlbaum.

Lewis, M. (2012). Obama's way. Vanity Fair. Pobrano z: https://www.vanityfair.com/ news/2012/10/michael-lewis-profile-barack-obama

Lurquin, J. H., Michaelson, L. E., Barker, J. E., Gustavson, D. E., von Bastian, C. C., Carruth, N. P., Miyake, A. (2016). No evidence of the ego-depletion effect across task characteristics and individual differences: A pre-registered study. PLoS One, 11, e0147770. https://doi.org/10.1371/journal.pone.0147770

Magen, E., Gross, J. (2007). Harnessing the need for immediate gratification: Cognitive reconstrual modulates the reward value of temptations. Emotion, 7(2), 415428. https://doi.org/10.1037/1528-3542.7.2.415

Mergenthaler, P., Lindauer, U., Dienel, G., Meisel, A. (2013). Sugar for the brain: The role of glucose in physiological and pathological brain function. Trends in Neurosciences, 36(10), 587-597. https://doi.org/10.1016/j.tins.2013.07.001

Metcalfe, J., Mischel, W. (1999). A hot/cool-system analysis of delay of gratification: Dynamics of willpower. Psychological Review, 106(1), 3-19. https://doi. org/10.1037/0033-295x.106.1.3

Miles, E., Sheeran, P., Baird, H., Macdonald, I., Webb, T., Harris, P. (2016). Does self-control improve with practice? Evidence from a six-week training program. Journal of Experimental Psychology: General, 145(8), 1075-1091. https://doi. org/10.1037/xge0000185

Mischel, W., Ebbesen, E. (1970). Attention in delay of gratification. Journal of Personality and Social Psychology, 16(2), 329-337. https://doi.org/10.1037/h0029815

Mischel, W., Ebbesen, E. I., Zeiss, A. (1972). Cognitive and attentional mechanisms in delay of gratification. Journal of Personality and Social Psychology, 21(2), 204-218. https://doi.org/10.1037/h0032198

Mischel, W., Metzner, R. (1962). Preference for delayed reward as a function of age, intelligence, and length of delay interval. The Journal Of Abnormal And Social Psychology, 64(6), 425-431. https://doi.org/10.1037/h0045046

Mischel, W., Shoda, Y., Rodriguez, M. (1989). Delay of gratification in children. Science, 244(4907), 933-938. https://doi.org/10.1126/science.2658056

Moore, B., Mischel, W., Zeiss, A. (1976). Comparative effects of the reward stimulus and its cognitive representation in voluntary delay. Journal of Personality and Social Psychology, 34(3), 419-424. https://doi.org/10.1037/0022-3514.34.3.419 
Muraven, M., Baumeister, R. F., Tice, D. M. (1999). Longitudinal improvement of self-regulation through practice: Building self-control strength through repeated exercise. The Journal of Social Psychology, 139, 446-457. https://doi. org/10.1080/00224549909598404

Muraven, M., Shmueli, D., Burkley, E. (2006). Conserving self-control strength. Journal of Personality and Social Psychology, 91(3), 524-537. https://doi.org/10.1037/00223514.91.3.524

Muraven, M., Slessareva, E. (2003). Mechanisms of self-control failure: Motivation and limited resources. Personality and Social Psychology Bulletin, 29(7), 894-906. https://doi.org/10.1177/0146167203029007008

Open Science Collaboration. (2015). Estimating the reproducibility of psychological science. Science, 349, aac4716. https://doi.org/10.1126/science.aac4716

Shenhav, A. (2017). The perils of losing control: Why self-control is not just another value-based decision. Psychological Inquiry, 28(2-3), 148-152. https://doi.org/10.1 080/1047840X.2017.1337407

Strack, F., Deutsch, R. (2004). Reflective and impulsive determinants of social behavior. Personality and Social Psychology Review, 8, 220-247. https://doi.org/10.1207/ s15327957pspr0803_1

Tangney, J. P., Baumeister, R. F., Boone, A. L. (2004). High self-control predicts good adjustment, less pathology, better grades, and interpersonal success. Journal of Personality, 72(2), 271-322. https:/ / doi.org/10.1111/j.0022-3506.2004.00263.x

Tice, D., Baumeister, R., Shmueli, D., Muraven, M. (2007). Restoring the self: Positive affect helps improve self-regulation following ego depletion. Journal of Experimental Social Psychology, 43(3), 379-384. https://doi.org/10.1016/j.jesp.2006.05.007

Vohs, K. D., Baumeister, R. F., Schmeichel, B. J. (2012). Motivation, personal beliefs, and limited resources all contribute to self-control. Journal of Experimental Social Psychology, 48, 943-947. https://doi.org/10.1016/j.jesp.2012.03.002

Wegner, D. M., Schneider, D. J., Carter, S. R., White, T. L. (1987). Paradoxical effects of thought suppression. Journal of Personality and Social Psychology, 53(1), 5-13. https://doi.org/10.1037/0022-3514.53.1.5

Werle, C., Wansink, B., Payne, C. (2014). Is it fun or exercise? The framing of physical activity biases subsequent snacking. Marketing Letters, 26(4), 691-702. https://doi. org/10.1007/s11002-014-9301-6

Zelazo, P., Craik, F., Booth, L. (2004). Executive function across the life span. Acta Psychologica, 115(2-3), 167-183. https://doi.org/10.1037/0022-3514.53.1.5 



\section{3.}

\section{Inteligencja a agresja. Czy wysokie IQ może uchronić przed wkroczeniem na ścieżkę przestępczą?}

Marta Bodecka (iD https://orcid.org/0000-0001-7766-1446

Akademia Pedagogiki Specjalnej im. Marii Grzegorzewskiej w Warszawie mbsd1@aps.edu.pl 
$\mathrm{N}$ ajbardziej znani przestępcy świata, przynajmniej w kulturze zachodniej, to nieuchwytni, seryjni mordercy. Stali się oni częścią popkultury, inspiracją dla książek, filmów czy seriali. Ich biografie od lat fascynują nie tylko psychologów, socjologów czy kryminologów, ale także wielu innych ludzi, którzy starają się zrozumieć motywy okrutnego działania. Obraz seryjnego mordercy, przekazywany przez różnego rodzaju media, przedstawia zwykle osobę bezduszną i bezwzględna, a przy tym niezwykle czarującą i ponadprzeciętnie inteligentna. Zjawisko to świetnie ilustruje sposób kreacji Teda Bundy'ego - jednego z najbardziej znanych amerykańskich seryjnych morderców, który stał się swoistym fenomenem popkulturowym. Podczas pobytu w więzieniu dostawał setki listów od zafascynowanych nim osób, rzesze dziennikarzy marzyło o przeprowadzeniu z nim wywiadu, a po wykonaniu wyroku (został skazany na karę śmierci) stał się bohaterem filmów, książek, a nawet piosenek. Jego sława nie ustała pomimo upływu lat. Niemalże co roku pojawiają się nowe produkcje opowiadające o historii życia tego najsłynniejszego amerykańskiego mordercy. Sława Teda i sposób, w jaki jest on przedstawiany, z pewnością umacnia wrażenie związku pomiędzy sprytem i inteligencją a agresją i przestępczościa.

Co ciekawe, badania empiryczne nie potwierdzaja istnienia pozytywnej relacji pomiędzy ogólnym czynnikiem inteligencji a agresją rozumiana jako cecha osobowości. Co więcej, osoby osadzone charakteryzują się niższym poziomem IQ niż reszta populacji. Jednakże w tym przypadku istnieją przypuszczenia, że mniej inteligentni przestępcy po prostu łatwiej dają się złapać. Niemniej jednak, na podstawie przeglądu dotychczasowej literatury, uzasadnionym wydaje się stwierdzenie, że wyższy poziom inteligencji może być czynnikiem chroniącym przed agresją i przestępczością. Relacja pomiędzy tymi konstruktami jest jednak skomplikowana i wciąż wymaga dalszych dociekań naukowych.

\section{INTELIGENCJA A AGRESJA}

Związek pomiędzy inteligencją a agresją wydaje się być zbadany dosyć gruntowanie. Już metaanaliza przeprowadzona przez Ackermana i Heggestada 
(1997) wykazała negatywną relację między inteligencją ogólną a agresją rozumiana jako cecha osobowości, czyli tendencją do reagowania w agresywny sposób (wielkość efektu =0,19). Przez lata naukowcy podejmowali się badań nad różnymi aspektami tego związku, dzięki czemu dziś dysponujemy obszernym zbiorem prac łączących poznawcze (intelektualne) funkcjonowanie człowieka z szeroko rozumiana agresywnością i przestępczością (np. Beaver i in., 2013; Morgan, Lilienfeld, 2000; Nixon, Thomas, Daffern, Ogloff, 2017; Oglive, Stewart, Chan, Shum, 2011; Schwartz i in., 2015). Istnieje na przykład spora grupa badań, która pokazuje negatywne powiązania między inteligencja emocjonalną a agresją (Garcia-Sancho, Salguero, Fernández-Berrocal, 2014). Jednakże pomiar tego rodzaju inteligencji i jej znaczenie wciąż nie jest porównywalne z tradycyjnym rozumieniem inteligencji (np. Harms, Credé, 2010). Dlatego też w niniejszym opracowaniu zostaną przedstawione różne aspekty relacji zachowań antyspołecznych i agresywnych $z$ inteligencją rozumiana w sposób tradycyjny - poznawczy, które zostały dobrze zbadane na przykład w świecie przestępczym (np. Beaver i in., 2013; Diamond, Morris, Barnes, 2012; Schwartz i in., 2015).

\section{INTELIGENCJA A PRZESTĘPCZOŚĆ}

Tradycja zarówno teoretycznych, jak i empirycznych badań dotyczących powiązań inteligencji i aktywności kryminalnej jest długa (Diamond i in., 2012). Przez lata naukowcom zajmującym się tym tematem udało się ustalić, że niski poziom inteligencji jest czynnikiem predysponującym do zaangażowania się w zachowania przestępcze (np. Beaver i in., 2013; Moffitt, Silva, 1988; Schwartz $\mathrm{i}$ in., 2015). Osoby z niższym ilorazem inteligencji częściej i wcześniej rozpoczynają „karierę” przestępcza, mają także większą szansę trafić do więzienia (McGloin, Pratt, 2003; Piquero, White, 2003). Inteligencja mierzona za pomocą testów IQ jest ujemnie skorelowana z przestępczością, a wielkość związku dla tej relacji mieści się zwykle w przedziale od 0,20 do 0,25 (Gottfredson, 2008; Hirschi, Hindelang, 1977). Podobne wyniki zostały uzyskane w wielu badaniach, w zróżnicowanych próbach i z wykorzystaniem różnych metod pomiaru zarówno inteligencji, jak i przestępczości (np. Beaver i in., 2013; Johansson, Kerr, 2005). Co więcej, negatywny związek pomiędzy inteligencją a przestępczością jest replikowalny zarówno na poziomie indywidualnym, jak i grupowym (Diamond i in., 2012). Badania prowadzone w USA wśród nastolatków wykazały, że istnieje silna ujemna korelacja pomiędzy średnim ilorazem inteligencji w danym regionie a wskaźnikiem przestępczości, w tym 
przestępstw majątkowych i przestępstw z użyciem przemocy (Beaver, Wright, 2011). Związek ten istnieje także w jednostkach penitencjarnych - im wyższy średni iloraz inteligencji w danej jednostce więziennej, tym mniej prawdopodobne, że dojdzie w niej do przemocy (Diamond i in., 2012).

Tymczasem średni iloraz inteligencji osób przebywających w więzieniach jest znacząco niższy w porównaniu z populacją osób nieskazanych (np. Beaver $i$ in., 2013; Herrnstein, Murray, 1994; Loeber i in., 2012; Moffitt, Silva, 1988; Wilson, Herrnstein, 1985). Więźniowie biorący udział w standardowych testach inteligencji zdobywają średnio 8 punktów IQ mniej niż osoby, które nigdy nie zostały skazane (Stattin, Kalckenberg-Larsson, 1993). Od 2019 roku wraz z zespołem badawczym prowadzimy badania między innymi wśród osób osadzonych, dzięki czemu uzyskaliśmy dane, które wskazują, że także w Polsce więźniowie charakteryzują się niższym poziomem inteligencji płynnej w porównaniu do osób przebywających na wolności. Wokół tego typu wniosków pojawia się jednak sporo kontrowersji. Niektórzy badacze już lata temu stwierdzili, że obniżony poziom IQ w populacji więziennej jest efektem tego, że mniej inteligentni przestępcy po prostu częściej dają się złapać (np. Murchison, 1926; Sutherland, 1931). Tymczasem to ci, którzy pozostają nieuchwytni, stanowią największe zagrożenie dla społeczeństwa (Lussier, Bouchard, Beauregard, 2011). Dane pochodzące z USA wskazuja, że co roku znaczny procent popełnionych przestępstw pozostaje nierozwiązany (Paré, Felson, Ouimet, 2007). Być może wyższy poziom IQ pozwala być skutecznym przestępca, to znaczy takim, który popełnia nielegalny czyn, ale nie daje się wykryć i skazać (Boccio, Beaver, Schwartz, 2018). Większość przestępstw z użyciem przemocy jest popełnianych pod wpływem impulsu, ich sprawcy nie planuja swojego czynu i zwykle szybko zostają aresztowani (Gottfredson, Hirschi, 1990). Jednakże są też tacy, którzy spędzają miesiące na przygotowywaniu się do nielegalnych działań. Przykładem mogą być tu osoby zaangażowane w przestępczość tzw. „białych kołnierzyków” (Sutherland, 1985). Profesjonalni złodzieje czy osoby o wysokim statusie ekonomicznym i społecznym, które zwykle popełniaja przestępstwa gospodarcze, spędzają więcej czasu na planowaniu niż na samym czynie, a wykrywalność ich działań jest dużo niższa niż przestępstw pospolitych (Jacobs, Cherbonneau, 2014; Ouellet, Bouchard, 2017; Vieraitis, Copes, Powell, Pike, 2015). Prawdopodobnie bycie „przestępcą sukcesu”, czyli planowanie nielegalnych działań, popełnianie ich i nie trafianie do więzienia, wymaga pewnego poziomu inteligencji (Boccio $\mathrm{i}$ in., 2018).

Okazuje się, że duże znaczenie może mieć w tym przypadku inteligencja werbalna: osoby o niższym poziomie tego rodzaju inteligencji są znacznie bar- 
dziej narażone na aresztowanie (Beaver i in., 2013; Hirschi, Hindelang, 1977). Badania podłużne przeprowadzone w próbie ponad 90000 amerykańskich nastolatków wykazały, że różnice pojawiają się także w grupie przestępców. Im wyższe zdolności werbalne posiadają osoby, które popełniaja przestępstwa, tym większe szanse na „osiagnięcie sukcesu”, tzn. uniknięcie skazania (Boccio $\mathrm{i}$ in., 2018). Jednakże związek ten pojawia się tylko w grupie mężczyzn, którzy nie mieli na swoim koncie dużej liczby wykroczeń. Autorzy tłumaczą ten efekt tym, że w przypadku osób, które popełniły wiele przestępstw, prawdopodobieństwo uwięzienia jest tak duże, że inteligencja werbalna przestaje być czynnikiem chroniącym. Z kolei w przypadku kobiet to, czy przestępczyni zostanie uwięziona, zależy w większym stopniu od rodzaju popełnionego przez nią czynu niż poziomu jej zdolności językowych (Boccio i in., 2018). Niemniej jednak warto zwrócić uwagę na związek inteligencji werbalnej z przestępczością, ponieważ ostatnimi czasy to właśnie poziom zdolności związanych z językiem (inteligencja werbalna, werbalna pamięć robocza) wydaje się być szczególnie istotny dla przewidywania zachowań antyspołecznych i agresywnych (Anderson, Hawes, Snow, 2016; Beaver i in., 2013; Boccio i in., 2018; De Brito, Viding, Kumari, Blackwood, Hodgins, 2013; Hirschi, Hindelang, 1977; Schwartz i in., 2015). Młodzi więźniowie uzyskują znacznie gorsze rezultaty w zadaniach słownych niż bezsłownych (wykonaniowych) w Skali inteligencji Wechslera (Isen, 2010; Romi, Marom, 2007; Tuominen i in., 2014). Istnieją także badania wskazujące na związek pomiędzy specyficznymi zaburzeniami językowymi a agresywnymi zachowaniami antyspołecznymi (np. Anderson $i$ in., 2016; Snow, Powell, 2011; Stattin, Klackenberg-Larsson, 1993). Jedno z badań podłużnych wykazało, że deficyty językowe zdiagnozowane w wieku 5 lat przewidują zaangażowanie się w działalność przestępczą nastolatków (Brownlie $\mathrm{i}$ in., 2004). Jest kilka modeli teoretycznych wyjaśniających to zjawisko, jedna z hipotez mówi, że ograniczone zdolności językowe powodują trudności w radzeniu sobie w interakcjach społecznych (Anderson i in., 2016; Fujiki, Brinton, Todd, 1996). Młodzi przestępcy mogą mieć kłopoty zarówno ze rozumieniem komunikatów werbalnych w różnych sytuacjach, jak i z wyrażaniem własnych myśli i dokładnym przekazywaniem informacji, co wydaje się szczególnie znaczące np. podczas przesłuchań czy rozpraw sądowych (Anderson i in., 2016). Niewatpliwie relacja ta jest także zapośredniczona przez problemy w szkole, których doświadcza większość osób trafiających do więzienia (Farrington, 1987; Isen, 2010; Wallinius i in., 2016). Szczególnie interesujące, lecz wymagające dalszych badań, są także różnice wewnątrzgrupowe. Osoby popełniające przestępstwa $\mathrm{z}$ użyciem przemocy wykazują większe deficyty językowe niż 
przestępcy nieprzemocowi, a gdy do tej relacji włączy się jeszcze niski poziom inteligencji niewerbalnej, ryzyko wystąpienia zachowań agresywnych może się znacząco zwiększyć (Snow, Powell, 2011).

\section{INTELIGENCJA, PSYCHOPATIA I PRZESTĘPCZOŚĆ}

Wiele wyników badań, pokazuje, że związek pomiędzy niskim poziomem inteligencji a przestępczością jest najsilniejszy w przypadku przestępstw popełnionych z użyciem przemocy (Dewolfe, Ryan, 1984; Heilbrun, 1982; Holland, Beckett, Levi, 1981; Holland, Holt, 1975). Z kolei wiele najbrutalniejszych zbrodni było dziełem osób o psychopatycznym rysie osobowości (Hare, McPherson, 1984; Hart, Kropp, Hare, 1988; Hemphill, Hare, Wong, 1998). Zgodnie z tym rozumowaniem, przestępcy psychopatyczni powinni charakteryzować się obniżonym poziomem IQ (Johansson, Kerr, 2005). Tymczasem osoby o psychopatycznym rysie osobowości przez lata były uważane za niezwykle czarujące i ponadprzeciętnie inteligentne (Cleckley, 1941). Termin „psychopatia” funkcjonuje w psychologii od lat. Tradycyjnie łączono ja z patologicznym egocentryzmem, brakiem empatii i skruchy, bezdusznością, powierzchownym urokiem i wysoką inteligencja, która ułatwiać miała oszukiwanie i manipulowanie innymi w celu osiagania osobistych korzyści (Cleckley, 1941). Dziś wiadomo, że większość osób cechujących się psychopatią spełnia także kryteria antyspołecznych (dyssocjalnych) zaburzeń osobowości (lecz większość osób z osobowością dyssocjalną nie spełnia kryteriów psychopatii; Poeppl i in., 2019). Osoby, najczęściej mężczyźni, z antyspołecznymi zaburzeniami osobowości charakteryzują się skłonnością do podejmowania ryzyka i impulsywnością (De Brito, Hodgins, 2009). Obydwie grupy, zarówno osoby z dyssocjalnymi zaburzeniami osobowości bez psychopatii, jak i z psychopatia, wykazują trudności w przetwarzaniu informacji afektywnych (Dolan, Fullam, 2006), w obydwu grupach występują charakterystyczne reakcje w mózgu na bodźce emocjonalne oraz anomalie w jego budowie (Gregory i in., 2012). Jednakże osoby charakteryzujące się osobowością dyssocjalną wykazują nadwrażliwość na zagrożenie, co jest związane $z$ hiperaktywnością ciała migdałowatego, w związku z czym mają dużą łatwość do angażowania się w reaktywne zachowania agresywne (Blair, Mitchel, Blair, 2005). Natomiast osoby o psychopatycznym rysie osobowości wykazują zmniejszoną wrażliwość mózgu na bodźce zagrażające, w ich przypadku obserwuje się np. brak reakcji ciała migdałowatego w odpowiedzi na twarze wyrażające strach (Dolan, Fullam, 2009). Osoby charakteryzujące się dyssocjalnymi zaburzeniami osobowości 
wraz z psychopatia, w porównaniu z osobami z zaburzeniami dyssocjalnymi bez psychopatii, zaczynają działalność kryminalną w młodszym wieku (Wong, 1985), częściej angażują się w agresję instrumentalną (Porter, Porter, 2007), mają także większą liczbę wyroków (Hare, McPherson, 1984; Kosson, Lorenz, Newman, 2006). Psychopatia jest uważana za stosunkowo rzadkie zjawisko (rozpowszechnienie w populacji to około 1\%), jednak osoby z diagnozą psychopatii popełniają nieproporcjonalnie więcej przestępstw, zwłaszcza tych z użyciem przemocy, a prawdopodobieństwo recydywy jest w ich przypadku większe niż w przypadku nie-psychopatów (Hare, 1999; Pedersen, Kunz, Rasmussen, Elsass, 2010).

Co ciekawe, badania empiryczne z wykorzystaniem Hare Psychopatby Checklist (PCL-R; Hare, 2003), narzędzia powszechnie używanego do badania psychopatii, opartego w dużej mierze na ocenie wskaźnika kryminalnych i antyspołecznych tendencji, w większości nie potwierdziły związku psychopatii z inteligencja (Hart, Forth, Hare, 1990). Wykazano jednak, że chociaż nie istnieja średnie różnice w poziomie IQ pomiędzy przestępcami psychopatycznymi i niepsychopatycznymi, to inteligencja i nasilenie zachowań przestępczych są skorelowane pozytywnie w grupach kryminalistów psychopatycznych, ale negatywnie w grupie przestępców niepsychopatycznych (Johansson, Kerr, 2005). Dla nie-psychopatów wyższa inteligencja, szczególnie werbalna, wiąże się z późniejszym startem w przestępczość, natomiast w grupie osób o cechach psychopatycznych oznacza wczesny start, gwałtowne przeobrażanie i bardziej problematyczne zachowania. Wydaje się więc, że wysoka inteligencja nie jest charakterystyczna dla psychopatii, ale jeśli już się pojawi, może zwiększać jej destrukcyjny potencjał poprzez interakcję z innymi cechami, takimi jak impulsywność, nieodpowiedzialność czy brak empatii (Johansson, Kerr, 2005). Z kolei dobrze znany ujemny związek pomiędzy przestępczością a inteligencja w grupie nie-psychopatów wynika prawdopodobnie z deficytów w zakresie funkcji wykonawczych - procesów kontroli poznawczej, które umożliwiaja realizację zachowań ukierunkowanych na cel (Jurado, Roselli, 2007; Moffit, 1990).

\section{FUNKCJE WYKONAWCZE A PRZESTĘPCZOŚĆ}

Według niektórych autorów tendencje do agresywnego zachowania, które pojawiają się we wczesnym dzieciństwie i utrzymują się przez całe życie, są wynikiem interakcji pomiędzy deficytami w funkcjonowaniu poznawczym a niekorzystnymi warunkami środowiska w dzieciństwie (Moffitt, 1993). Dwa 
duże badania metaanalityczne potwierdziły, że deficyty neuropsychiczne w zakresie funkcji wykonawczych są jednym z kluczowych czynników powstawania i utrzymywania się zachowań antyspołecznych i agresywnych (Morgan, Lilienfeld, 2000; Oglive i in., 2011).

Funkcje wykonawcze (executive functions) są to procesy poznawcze wyższego rzędu, pozwalające na inicjację, planowanie, regulację, sekwencjonowanie czy hamowanie złożonych myśli i zachowań ukierunkowanych na realizację celu (Jurado, Roselli, 2007; Royall i in., 2002). Zróżnicowanie w zakresie kontroli poznawczej i funkcji wykonawczych jest nierozerwalnie związane z różnicami w ilorazie inteligencji (Ardila, Pineda, Rosselli, 2000; Kane, Conway, Hambrick, Engle, 2007; Oglive i in., 2011). Tradycyjnie kluczową rolę w regulacji funkcji wykonawczych przypisywano korze przedczołowej, jednakże dziś wiadomo, że optymalne funkcjonowanie w ich zakresie zależy od integralności działania całego mózgu (Funahashi, 2001; Prabhakaran i in., 2000; Stuss, Alexander, 2000; Stuss, Levine, 2002). Funkcje wykonawcze umożliwiają samoregulację, włączając w to regulację emocji i kontrolowanie zachowania, a deficyty w ich zakresie prowadzą do społecznie niewłaściwych reakcji, niezdolności do planowania i rozwiązywania problemów, rozproszenia uwagi, słabej oceny konsekwencji działań, słabej pamięci czy osłabionej zdolności do hamowania impulsów (Fuster, 2000; Mesulam, 2002).

W literaturze występuje podział na zimne i gorące funkcje wykonawcze (np. Chan, Shum, Toulopoulou, Chen, 2008; Poon, 2018). Do pierwszych zaliczamy procesy pozwalające na rozwiązywanie abstrakcyjnych problemów, oderwanych od kontekstu, wymagających aktywności pamięci roboczej, planowania i monitorowania zachowania, hamowania odpowiedzi, utrzymywania i przerzucania uwagi (Chan i in., 2008; Rubia, 2011). Funkcje gorące natomiast maja zazwyczaj aspekt afektywny i motywacyjny, sa związane z podejmowaniem decyzji, rozpoznawaniem emocji czy empatią (Baez i in., 2012; Rubia, 2011). Niektóre badania sugerują, że przestępcy o dyssocjalnym rysie osobowości (bez towarzyszącej psychopatii) wykazują deficyty w zakresie zimnych funkcji wykonawczych, takich jak planowanie czy korzystanie z zasobów pamięci roboczej. Przestępcy psychopatyczni natomiast mają deficyty w zakresie goraccych funkcji wykonawczych, takich jak afektywne podejmowanie decyzji (Mitchell, Avny, Blair, 2006; Mitchell, Colledge, Leonard, Blair, 2002). Jednakże wyniki nowszego badania, w którym wzięli udział dorośli mężczyźni skazani za przestępstwa z użyciem przemocy oraz mężczyźni nie będący przestępcami (De Brito i in., 2013), wykazały, że sprawcy przemocy wykazują deficyty w zakresie zarówno zimnych, jak i gorących funkcji wykonawczych. Przestępcy 
z antyspołecznymi zaburzeniami osobowości, zarówno ci z psychopatią, jak i bez, wykazują deficyty w zakresie pamięci werbalnej, a także w adaptacyjnym afektywnym podejmowaniu decyzji. Mają trudności w uczeniu się na podstawie sygnałów o karze, nie modyfikują swojego zachowania pomimo zmieniających się okoliczności. Jak piszą autorzy badania:

„Połączenie tych deficytów może w pewnym stopniu wyjaśnić, dlaczego sprawcy przemocy charakteryzujący się antyspołecznymi zaburzeniami osobowości z psychopatią i bez psychopatii charakteryzują się nieodpowiedzialnością, lekkomyślnością, uporczywym agresywnym zachowaniem i zaangażowaniem w wiele innych typów zachowań antyspołecznych, mimo że wiedza, że takie zachowanie może prowadzić do negatywnych konsekwencji dla nich samych i/lub innych" (De Brito i in., 2013, s. 9).

\section{INTELIGENCJA JAKO CZYNNIK OCHRONNY}

Niski poziom inteligencji, czy deficyty w zakresie funkcji wykonawczych sa dobrze znanym i gruntownie przebadanym czynnikiem ryzyka dla zachowań przestępczych. Znacznie mniej wiadomo o potencjalnej funkcji ochronnej wysokiej inteligencji (Ttofi i in., 2016). Jednym z pierwszych badań, w którym próbowano odpowiedzieć na pytanie, czy wyższe IQ może być czynnikiem chroniącym przed zaangażowaniem się w działalność przestępcza, było to prowadzone w Danii przez Elizabeth Kandel i jej współpracowników (1988). W badaniu udział wzięły cztery grupy dorosłych mężczyzn: w pierwszej znalazły się osoby z grupy ryzyka (ich ojcowie popełnili poważne przestępstwa), które pomimo tego nie weszły na ścieżkę przestępcza, w grupie drugiej znalazły się osoby z grupy ryzyka, które popełniły przestępstwo, w grupie trzeciej były osoby nie obarczone ryzykiem (ich ojcowie nie popełnili przestępstwa), które także nie przejawiały zachowań antyspołecznych, a w grupie czwartej osoby spoza grupy ryzyka, które zostały przestępcami. Okazało się, że czynnikiem, który różnił osoby obarczone ryzykiem, był poziom IQ. Osoby z grupy pierwszej miały istotnie wyższy iloraz inteligencji od osób z grupy drugiej. Pozwoliło to autorom na wysnucie wniosku, że wyższe IQ może być czynnikiem buforującym ryzyko wkroczenia na ścieżkę przestępczą, wynikające z czynników rodzinnych i społecznych.

Późniejsze dociekania naukowe potwierdziły te przypuszczenia. Metaanaliza 15 badań podłużnych pozwoliła na wysnucie wniosku, że inteligencja chroni 
przed popełnieniem poważnego przestępstwa (Ttofi i in., 2016). Efekt ten jest szczególnie widoczny w grupach zagrożonych przestępczością, np. wśród dzieci matek chorujących psychicznie (Garmezy, 1974) czy dzieci dorastających w trudnej sytuacji ekonomicznej (Werner, Smith, 1982). Młodzi ludzie, którzy doświadczają przeciwności losu, lepiej radzą sobie w życiu, kiedy potrafią rozwiązywać problemy i osiagają sukcesy w szkole (Masten, Best, Garmezy, 1990), a na to właśnie pozwala wyższy poziom inteligencji (np. Sternberg, 2005). Według autorów metaanalizy nie można wskazać dokładnych mechanizmów, które stoja za protekcyjną funkcją IQ. Poprzednie badania wykazały jednak, że zdolności intelektualne mogą modyfikować tendencje do wrogiej interpretacji rzeczywistości wynikające ze specyficznego przetwarzania informacji społecznych (Crick, Dodge, 1994), wskazywać na funkcje wykonawcze, które pozwalaja planować i kontrolować zachowania (Raine, 2013), rekompensować niekompletne wykształcenie (Damian, Su, Shanahan, Trautwein, Roberts, 2015). Co więcej, badania pokazuja, że osoby charakteryzujące się wysokim poziomem inteligencji ogólnej, są w stanie przewidzieć moralne konsekwencje swoich zachowań, charakteryzuje je także mniejsza impulsywność, dzięki czemu są w stanie porównać zyski i straty wynikające z podejmowanych działań (Schwartz i in., 2015).

Wielu badaczy podkreśla szczególne znaczenie inteligencji werbalnej, która sprzyja efektywnym interakcjom z innymi ludźmi, pozwala zrozumieć generowane przez nich komunikaty i jasno wyrażać własne myśli (Anderson $\mathrm{i}$ in., 2016), co z pewnością może zapobiec wielu sytuacjom konfliktowym, w wyniku których mogłoby dojść do zachowań agresywnych. Co więcej, inteligencja werbalna sprzyja socjalizacji i przekłada się na lepsze funkcjonowanie w świecie społecznym od najmłodszych lat. Wysokie zdolności werbalne sa nagradzane w szkole, te nagrody dostarczaja pozytywnych wzmocnień, które sprawiaja, że dziecko staje się przywiązane do konwencjonalnego porządku społecznego i stara się zachowywać praworządnie (Hirschi, 1969). Poza tym zdolności werbalne pozwalają na poradzenie sobie w systemie wymierzającym sprawiedliwość, jeśli się już w ten system wejdzie, począwszy od przesłuchań, skończywszy na rozprawie sądowej. Czasem mogą przyczynić się nawet do uniknięcia kary za popełnione czyny (Boccio i in., 2018).

\section{PODSUMOWANIE I OGRANICZENIA}

Zbiór prac, dotyczący związków inteligencji z agresywnością czy przestępczością, pozwala stwierdzić, że niższy poziom inteligencji może predysponować 
do angażowania się w zachowania przestępcze i przemocowe. Wniosek ten, wysnuty na podstawie dostępnych danych empirycznych, pomimo pewnych wyjątków (np. ponadprzeciętnie inteligentnych osób o psychopatycznym rysie osobowości), wydaje się dość pewny. Podobnie jak to, że inteligencja może być czynnikiem chroniącym przed wkroczeniem na przestępczą ścieżkę. Warto jednak zastanowić się nad ograniczeniami badań dotyczących związków pomiędzy inteligencją a przestępczością. Beaver i in. (2013) wskazali pięć najbardziej naglących problemów, które dotykaja prac z tego obszaru. Chociaż badacze postanowili się do nich odnieść, analizując dane pochodzące $\mathrm{z}$ amerykańskiego podłużnego badania dotyczącego zdrowia młodzieży - National Longitudinal Study of Adolescent Health (Add Health; Harris, 2009) i ostatecznie potwierdzili ujemny związek IQ z przestępczościa, to większość wymienianych przez nich ograniczeń wciąż wydaje się być aktualna.

Pierwszym wymienianym przez autorów ograniczeniem jest to, że w większości badań dotyczących inteligencji i przestępczości uczestniczą więźniowie, pacjenci psychiatryczni, przestępcy seksualni lub inne niereprezentatywne grupy osób (Diamond i in., 2012; Guay, Ouimet, Proulx, 2005; Hanson, Scott, Steffy, 1995; Holland i in., 1981; Holland, Holt, 1975), niewiele jest natomiast aktualnych badań opartych na reprezentatywnych próbach kobiet i mężczyzn. Co więcej, większość prac naukowych czerpie dane z oficjalnych źródeł pochodzących od służb lub opiera się na kwestionariuszach samoopisowych. Tymczasem wiadomo, że w oficjalnych raportach znajdują się informacje wyłącznie o tych przestępstwach, które zostały wykryte. Biorąc pod uwagę fakt, że wiele spraw kryminalnych pozostaje nierozwiązanych (Hindelang, Hirschi, Weis, 1981; O’Brien, Shichor, Decker, 1980), możliwe, że IQ jest związane przede wszystkim z wykrywaniem sprawców, a nie z etiologia przestępczości (Herrnstein, Murray, 1994; Moffitt, Silva, 1988). Z kolei badania samoopisowe mogą dostarczać nierzetelnych danych, ponieważ ludzie przedstawiają się zazwyczaj w jak najlepszym świetle (Paulhus, 1998). Więźniowie wydają się być szczególnie zmotywowani do manipulowania wrażeniem, jakie wywieraja na innych, zwłaszcza kiedy ocena może mieć wpływ na proces sądowy lub zwolnienie warunkowe (Andrews, Meyer, 2003). Kolejnym ograniczeniem sa niewystarczające dane potwierdzające ujemny związek IQ z przestępczością w grupach innych niż biali mężczyźni. Tymczasem wcześniejsze badania pokazują, że prawidłowości dotyczące zarówno IQ, jak i przestępczości różnią się w zależności od grup społecznych (Bell, Willson, Wilman, Dave, Silverstone, 2006; Halpern, LaMay, 2000; Lauritsen, Heimer, Lynch, 2009). Następny zarzut jest taki, że istniejące badania nie pozwalają na wyodrębnienie czynników 
związanych z IQ i wpływających na przestępczość od innych procesów poznawczych, zwłaszcza funkcji wykonawczych. Według badań funkcje wykonawcze, takie jak samoregulacja czy samokontrola, sa jednymi z najsilniejszych i najbardziej konsekwentnych predyktorów zachowań przestępczych (Oglive $\mathrm{i}$ in., 2011). Tymczasem większość badań testujących związek przestępczości z IQ nie bada jednocześnie funkcji wykonawczych, co sprawia, że iloraz inteligencji może być po prostu wskaźnikiem dla innych procesów poznawczych, wobec czego trudno określić jego rzeczywisty wpływ na przestępczość. Ostatnim ograniczeniem według autorów jest niedostateczna wiedza na temat tego, w jakim stopniu IQ sprawcy jest związane z przetwarzaniem jego sprawy przez system sądowniczy. Wiele czynników może różnicować sposób, w jaki dana osoba jest traktowana przez system karny, należy do nich ciężar popełnionego przestępstwa (Reitz, 2011), jak również rasa, płeć czy wiek (Beaver, DeLisi, Mears, Stewart, 2009). Ostatnie badania pokazują, że ważny może być także poziom inteligencji werbalnej (Boccio i in., 2018).

Konkludując, pomimo obszernej literatury i wydawałoby się dobrze zbadanego negatywnego związku pomiędzy inteligencja a agresywnością czy przestępczością, pojawiają się pewne wątpliwości. Ich rozwianie wymagałoby pewnie większej liczby badań podłużnych, wśród różnych grup, na różnych szerokościach geograficznych oraz zbadania całego spektrum osób popełniających przestępstwa, tych $z$ wysoką i niską inteligencją, tych schwytanych i skazanych, oraz tych, których nie dosięgła sprawiedliwość za popełnione czyny, chociaż zapewne byłoby to trudne, bo nieuchwytni przestępcy stanowią dość niedostępną grupę badawczą...

\section{BIBLIOGRAFIA}

Ackerman, P. L., Heggestad, E. D. (1997). Intelligence, personality, and interests: Evidence for overlapping traits. Psychological Bulletin, 121(2), 219-245. https://doi. org/10.1037/0033-2909.121.2.219

Anderson, S. A., Hawes, D. J., Snow, P. C. (2016). Language impairments among youth offenders: A systematic review. Children and Youth Services Review, 65, 195-203. https://doi.org/10.1016/j.childyouth.2016.04.004

Andrews, P., Meyer, R. G. (2003). Marlowe-Crowne social desirability scale and short form C: Forensic norms. Journal of Clinical Psychology, 59(4), 483-492. https://doi. org/10.1002/jclp.10136 
Ardila, A., Pineda, D., Rosselli, M. (2000). Correlation between intelligence test scores and executive function measures. Archives of Clinical Neuropsychology, 15(1), 31-36. https://doi.org/10.1093/arclin/15.1.31

Baez, S., Rattazzi, A., Gonzalez-Gadea, M. L., Torralva, T., Vigliecca, N., Decety, J., ..., Ibanez, A. (2012). Integrating intention and context: Assessing social cognition in adults with Asperger syndrome. Frontiers in Human Neuroscience, 6, 302. https:// doi.org/10.3389/fnhum.2012.00302

Beaver, K. M., DeLisi, M., Mears, D. P., Stewart, E. A. (2009). Low self-control and contact with the criminal justice system in a nationally representative sample of males. Justice Quarterly, 26(4), 695-715. https://doi. org/10.1080/07418820802593352

Beaver, K. M., Schwartz, J. A., Nedelec, J. L., Connolly, E. J., Boutwell, B. B., Barnes, J. C. (2013). Intelligence is associated with criminal justice processing: Arrest through incarceration. Intelligence, 41(5), 277-288. https:/ /doi.org/10.1016/j.intell.2013.05.001

Beaver, K. M., Wright, J. P. (2011). The association between county-level IQ and county-level crime rates. Intelligence, 39(1), 193-197. https://doi.org/10.1016/j. intell.2010.12.002

Bell, E. C., Willson, M. C., Wilman, A. H., Dave, S., Silverstone, P. H. (2006). Males and females differ in brain activation during cognitive tasks. NeuroImage, 30(2), 529-538. https://doi.org/10.1016/j.neuroimage.2005.09.049

Blair, R. J. R., Mitchell, D. G. V., Blair, K. S. (2005). The psychopath: Emotion and the brain. Oxford: Blackwell Publishing.

Boccio, C. M., Beaver, K. M., Schwartz, J. A. (2018). The role of verbal intelligence in becoming a successful criminal: Results from a longitudinal sample. Intelligence, 66, 24-31. https://doi.org/10.1016/j.intell.2017.10.003

Brownlie, E. B., Beitchman, J. H., Escobar, M., Young, A., Atkinson, L., Johnson, C., ..., Douglas, L. (2004). Early language impairment and young adult delinquent and aggressive behavior. Journal of Abnormal Child Psychology, 32(4), 453-467. https:/ / doi.org/10.1023/B:JACP.0000030297.91759.74

Chan, R. C. K., Shum, D., Toulopoulou, T., Chen, E. Y. H. (2008). Assessment of executive functions: Review of instruments and identification of critical issues. Archives of Clinical Neuropsychology, 23(2), 201-216. https://doi.org/10.1016/j. acn.2007.08.010

Cleckley, H. M. (1941). The mask of sanity: An attempt to reinterpret the so-called psychopathic personality. St. Louis: The C. V. Mosby company. 
Crick, N. R., Dodge, K. A. (1994). A review and reformulation of social information processing mechanisms in children's social adjustment. Psychological Bulletin, 115(1), 74-101. https://doi.org/10.1037/0033-2909.115.1.74

Damian, R. I., Su, R., Shanahan, M., Trautwein, U., Roberts, B. W. (2015). Can personality traits and intelligence compensate for background disadvantage? Predicting status attainment in adulthood. Journal of Personality and Social Psychology, 109(3), 473-489. https://doi.org/10.1037/pspp0000024

De Brito, S. A., Hodgins, S. (2009). Antisocial personality disorder. W: M. McMurran, R. Howard (red.), Personality, personality disorder and violence: An evidence based approach (s. 133-153). Chichester: Wiley-Blackwell.

De Brito, S. A., Viding, E., Kumari, V., Blackwood, N., Hodgins, S. (2013). Cool and hot executive function impairments in violent offenders with antisocial personality disorder with and without psychopathy. PLoS One, 8(6), e65566. https://doi. org/10.1371/journal.pone.0065566

Dewolfe, A. S., Ryan, J. J. (1984). Wechsler performance IQ > verbal IQ index in a forensic sample: A reconsideration. Journal of Clinical Psychology, 40(1), 291-294. https://doi.org/10.1002/1097-4679(198401)40:1<291::AIDJCLP2270400153>3.0.CO;2-C

Diamond, B., Morris, R. G., Barnes, J. C. (2012). Individual and group IQ predict inmate violence. Intelligence, 40(2), 115-122. https://doi.org/10.1016/j.intell.2012.01.010

Dolan, M., Fullam, R. (2006). Face affect recognition deficits in personality disordered offenders: Association with psychopathy. Psychological Medicine, 36(11), 1563-1569. https:// doi.org/10.1017/S0033291706008634

Dolan, M. C., Fullam, R. S. (2009). Psychopathy and functional magnetic resonance imaging blood oxygenation level-dependent responses to emotional faces in violent patients with schizophrenia. Biological Psychiatry, 66(6), 570-577. https://doi. org/10.1016/j.biopsych.2009.03.019

Farrington, D. P. (1987). Early precursors of frequent offending. W: J. Q. Wilson, G. C. Loury (red.), From children to citizens: Families, schools, and delinquency prevention (s. 27-50). Nowy Jork: Springer. https://doi.org/10.1007/978-1-4615-7029-5_2

Fujiki, M., Brinton, B., Todd, C. M. (1996). Social skills of children with specific language impairment. Language, Speech, and Hearing Services in Schools, 27(3), 195-202. https:// doi.org/10.1044/0161-1461.2703.195

Funahashi, S. (2001). Neuronal mechanisms of executive control by the prefrontal cortex. Neuroscience Research, 39(2), 147-165. https://doi.org/10.1016/S01680102(00)00224-8 
Fuster, J. M. (2000). Executive frontal functions. Experimental Brain Research, 133(1), 66-70. https://doi.org/10.1007/s002210000401

García-Sancho, E., Salguero, J. M., Fernández-Berrocal, P. (2014). Relationship between emotional intelligence and aggression: A systematic review. Aggression and Violent Behavior, 19(5), 584-591. https://doi.org/10.1016/j.avb.2014.07.007

Garmezy, N. (1974). The study of competence in children at risk for severe psychopathology. W: E. J. Anthony, C. Koupernik (red.), The child in his family: Children at psychiatric risk (77-97). Nowy Jork: Wiley.

Gottfredson, L. S. (2008). Of what value is intelligence? W: A. Prifitera, D. H. Saklofske, L. G. Weiss (red.), WISC-IV clinical assessment and intervention (s. 545-563). San Diego: Elsevier Academic Press.

Gottfredson, M. R., Hirschi, T. (1990). A general theory of crime. Stanford: Stanford University Press.

Gregory, S., Ffytche, D., Simmons, A., Kumari, V., Howard, M., Blackwood, N. (2012). The antisocial brain: Psychopathy matters: A structural MRI investigation of antisocial male violent offenders. Archives of General Psychiatry, 69(9), 962-972. https://doi.org/10.1001/archgenpsychiatry.2012.222

Guay, J. P., Ouimet, M., Proulx, J. (2005). On intelligence and crime: A comparison of incarcerated sex offenders and serious non-sexual violent criminals. International Journal of Law and Psychiatry, 28(4), 405-417. https://doi.org/10.1016/j. ijlp.2004.03.010

Halpern, D. F., LaMay, M. L. (2000). The smarter sex: A critical review of sex differences in intelligence. Educational Psychology Review, 12(2), 229-246. https://doi. org/10.1023/A:1009027516424

Hanson, K. R., Scott, H., Steffy, R. A. (1995). A comparison of child molesters and nonsexual criminals: Risk predictors and long-term recidivism. Journal of Research in Crime and Delinquency, 32(3), 325-337. https://doi.org/10.1177/0022427895032003004

Hare, R. D. (1999). Psychopathy as a risk factor for violence. Psychiatric Quarterly, 70(3), 181-197. https://doi.org/10.1023/A:1022094925150

Hare, R. D. (2003). Manual for the Revised Psychopathy Checklist ( $2^{\text {nd }}$ ed.). Toronto-Ontario: Multi-Health Systems.

Hare, R. D., McPherson, L. M. (1984). Violent and aggressive behavior by criminal psychopaths. International Journal of Law and Psychiatry, 7(1), 35-50. https://doi. org/10.1016/0160-2527(84)90005-0

Harms, P. D., Credé, M. (2010). Emotional intelligence and transformational and transactional leadership: A meta-analysis. Journal of Leadership \& Organizational Studies, 17(1), 5-17. https:// doi.org/10.1177/1548051809350894 
Harris, K. M. (2009). The National Longitudinal Study of Adolescent Health (Add Health), waves I \& II, 1994-1996; wave III, 2001-2002; wave IV, 2007-2009. Chapel Hill: Carolina Population Center, University of North Carolina at Chapel Hill.

Hart, S. D., Forth, A. E., Hare, R. D. (1990). Performance of criminal psychopaths on selected neuropsychological tests. Journal of Abnormal Psychology, 99(4), 374-379. https:// doi.org/10.1037/0021-843X.99.4.374

Hart, S. D., Kropp, P. R., Hare, R. D. (1988). Performance of male psychopaths following conditional release from prison. Journal of Consulting and Clinical Psychology, 56(2), 227-232. https://doi.org/10.1037/0022-006X.56.2.227

Heilbrun, A. B. (1982). Cognitive models of criminal violence based upon intelligence and psychopathy levels. Journal of Consulting and Clinical Psychology, 50(4), 546-557. https://doi.org/10.1037/0022-006X.50.4.546

Hemphill, J. F., Hare, R. D., Wong, S. (1998). Psychopathy and recidivism: A review. Legal and Criminological Psychology, 3(1), 139-170. https://doi. org/10.1111/j.2044-8333.1998.tb00355.x

Herrnstein, R. J., Murray, C. (1994). The Bell curve: Intelligence and class structure in American life. Nowy Jork: Free Press.

Hindelang, M. J., Hirschi, T., Weis, J. G. (1981). Measuring delinquency. Beverly Hills: Sage.

Hirschi, T. (1969). Causes of delinquency. Berkeley: University of California Press.

Hirschi, T., Hindelang, M. J. (1977). Intelligence and delinquency: A revisionist review. American Sociological Review, 42(4), 571-587. https: / doi.org/10.2307/2094556

Holland, T. R., Beckett, G. E., Levi, M. (1981). Intelligence, personality, and criminal violence: A multivariate analysis. Journal of Consulting and Clinical Psychology, 49(1), 106-111. https://doi.org/10.1037/0022-006X.49.1.106

Holland, T. R., Holt, N. (1975). Prisoner intellectual and personality correlates of offense severity and recidivism. Journal of Clinical Psychology, 31(4), 667-672. https:/ / doi.org/10.1002/1097-4679(197510)31:4<667::AID-JCLP2270310421>3.0. $\mathrm{CO} ; 2-9$

Isen, J. (2010). A meta-analytic assessment of Wechsler's $\mathrm{P}>\mathrm{V}$ sign in antisocial populations. Clinical Psychology Review, 30(4), 423-435. https://doi.org/10.1016/j. cpr.2010.02.003

Jacobs, B. A., Cherbonneau, M. (2014). Auto theft and restrictive deterrence. Justice Quarterly, 31(2), 344-367. https://doi.org/10.1080/07418825.2012.660977

Johansson, P., Kerr, M. (2005). Psychopathy and intelligence: A second look. Journal of Personality Disorders, 19(4), 357-369. https://doi.org/10.1521/pedi.2005.19.4.357 
Jurado, M. B., Roselli, M. (2007). The elusive nature of executive functions: A review of our current understanding. Neuropsychological Reviews, 17(3), 213-233. https:/ / doi.org/10.1007/s11065-007-9040-z

Kane, M. J., Conway, A. R. A., Hambrick, D. Z., Engle, R. W. (2007). Variation in working memory as variation in executive attention and control. W: A. R. A. Conway, C. Jarrold, M. J. Kane, A. Miyake, J. N. Towse (red.), Variation in working memory (s. 21-48). Oxford: Oxford University Press. https://doi.org/10.1093/ acprof:oso/9780195168648.001.0001

Kandel, E., Mednick, S. A., Kirkegaard-Sorensen, L., Hutchings, B., Knop, J., Rosenberg, R., Schulsinger, F. (1988). IQ as a protective factor for subjects at high-risk for antisocial behavior. Journal of Consulting and Clinical Psychology, 56(2), 224-226. https:// doi.org/10.1037/0022-006X.56.2.224

Kosson, D. S., Lorenz, A. R., Newman, J. P. (2006). Effects of comorbid psychopathy on criminal offending and emotion processing in male offenders with antisocial personality disorder. Journal of Abnormal Psychology, 115(4), 798-806. https:/ / doi. org/10.1037/0021-843X.115.4.798

Lauritsen, J. L., Heimer, K., Lynch, J. P. (2009). Trends in the gender gap in violent offending: New evidence from the National Crime Victimization Survey. Criminology, 47(2), 361-399. https://doi.org/10.1111/j.1745-9125.2009.00149.x

Loeber, R., Menting, B., Lynam, D. R., Moffitt, T. E., Stouthamer-Loeber, M., Stallings, R., ..., Pardini, D. (2012). Findings from the Pittsburgh Youth Study: Cognitive impulsivity and intelligence as predictors of the age-crime curve. Journal of the American Academy of Child \& Adolescent Psychiatry, 51(11), 1136-1149. https:/ / doi.org/10.1016/j.jaac.2012.08.019

Lussier, P., Bouchard, M., Beauregard, E. (2011). Patterns of criminal achievement in sexual offending: Unravelling the „successful” sex offender. Journal of Criminal Justice, 39(5), 433-444. https://doi.org/10.1016/j.jcrimjus.2011.08.001

Masten, A. S., Best, K., Garmezy, N. (1990). Resilience and development: Contributions from the study of children who overcome adversity. Development and Psychopathology, 2(4), 425-444. https://doi.org/10.1017/S0954579400005812

McGloin, J. M., Pratt, T. C. (2003). Cognitive ability and delinquent behavior among inner-city youth: A life-course analysis of main, mediating and interaction effects. International Journal of Offender Therapy and Comparative Criminology, 47(3), 253-271. https://doi.org/10.1177/0306624X03047003002

Mesulam, M.-M. (2002). The human frontal lobes: Transcending the default mode through contingent encoding. W: D. T. Stuss, R. T. Knight (red.), Principles of frontal lobe function (s. 8-30). Oxford: Oxford University Press. https://doi.org/10.1093/ acprof:oso/9780195134971.003.0002 
Mitchell, D. G. V., Avny, S. B., Blair, R. J. R. (2006). Divergent patterns of aggressive and neurocognitive characteristics in acquired versus developmental psychopathy. Neurocase, 12(3), 164-178. https://doi.org/10.1080/13554790600611288

Mitchell, D. G. V., Colledge, E., Leonard, A., Blair, R. J. R. (2002). Risky decisions and response reversal: Is there evidence of orbitofrontal cortex dysfunction in psychopathic individuals? Neuropsychologia, 40(12), 2013-2022. https://doi.org/10.1016/ S0028-3932(02)00056-8

Moffitt, T. E. (1990). The neuropsychology of juvenile delinquency: A critical review. Crime and Justice, 12, 99-169. https:/ / doi.org/10.1086/449165

Moffitt, T. E. (1993). The neuropsychology of conduct disorder. Development and Psychopathology, 5(1), 135-151. https://doi.org/10.1017/S0954579400004302

Moffitt, T. E., Silva, P. A. (1988). IQ and delinquency: A direct test of the differential detection hypothesis. Journal of Abnormal Psychology, 97(3), 330-333. https://doi. org/10.1037/0021-843X.97.3.330

Morgan, A. B., Lilienfeld, S. O. (2000). A meta-analytic review of the relation between antisocial behavior and neuropsychological measures of executive function. Clinical Psychology Review, 20(1), 113-136. https:/ / doi.org/10.1016/S0272-7358(98)00096-8

Murchison, C. (1926). Criminal intelligence. Worcester: Clark University Press.

Nixon, M., Thomas, S. D., Daffern, M., Ogloff, J. R. (2017). Estimating the risk of crime and victimisation in people with intellectual disability: A data-linkage study. Social Psychiatry and Psychiatric Epidemiology, 52(5), 617-626. https://doi. org/10.1007/s00127-017-1371-3

O'Brien, R. M., Shichor, D., Decker, D. L. (1980). An empirical comparison of the validity of UCR and NCS crime rates. The Sociological Quarterly, 21(3), 391-401. https://doi.org/10.1111/j.1533-8525.1980.tb00620.x

Oglive, J. M., Stewart, A. L., Chan, R. C. K., Shum, D. K. (2011). Neuropsychological measures of executive function and antisocial behavior: A meta-analysis. Criminology, 49(4), 1063-1107. https://doi.org/10.1111/j.1745-9125.2011.00252.x

Ouellet, F., Bouchard, M. (2017). Only a matter of time? The role of criminal competence in avoiding arrest. Justice Quarterly, 34(4), 699-726. https:/ / doi.org/10.10 80/07418825.2016.1219761

Paré, P. P., Felson, R. B., Ouimet, M. (2007). Community variation in crime clearance: A multilevel analysis with comments on assessing police performance. Journal of Quantitative Criminology, 23(3), 243-258. https://doi.org/10.1007/s10940-007-9028-0

Paulhus, D. L. (1998). Paulhus Deception Scales (PDS): The balanced inventory of desirable responding-7: User's manual. North Tanawanda: Multi-Health Systems.

Pedersen, L., Kunz, C., Rasmussen, K., Elsass, P. (2010). Psychopathy as a risk factor for violent recidivism: Investigating the Psychopathy Checklist Screening Ver- 
sion (PCL:SV) and the Comprehensive Assessment of Psychopathic Personality (CAPP) in a forensic psychiatric setting. International Journal of Forensic Mental Health, 9(4), 308-315. https://doi.org/10.1080/14999013.2010.526681

Piquero, A. R., White, N. A. (2003). On the relationship between cognitive abilities and life-course-persistent offending among a sample of African Americans: A longitudinal test of Moffitt's hypothesis. Journal of Criminal Justice, 31(5), 399-409. https:// doi.org/10.1016/S0047-2352(03)00046-1

Poeppl, T. B., Donges, M. R., Mokros, A., Rupprecht, R., Fox, P. T., Laird, A. R., ..., Eickhoff, S. B. (2019). A view behind the mask of sanity: Meta-analysis of aberrant brain activity in psychopaths. Molecular Psychiatry, 24(3), 463-470. https://doi. org/10.1038/s41380-018-0122-5

Poon, K. (2018). Hot and cool executive functions in adolescence: Development and contributions to important developmental outcomes. Frontiers in Psychology, 8, 2311. https:// doi.org/10.3389/fpsyg.2017.02311

Porter, S., Porter, S. (2007). Psychopathy and violent crime. W: H. Herve, J. C. Yuille (red.), The psychopath: Theory, research, and practice (s. 287-300). Mahwah: Lawrence Erlbaum Associates Publishers.

Prabhakaran, V., Narayanan, K., Zhao, Z., Gabrieli, J. D. E. (2000). Integration of diverse information in working memory within the frontal lobe. Nature Neuroscience, 3(1), 85-90. https://doi.org/10.1038/71156

Raine, A. (2013). The anatomy of violence: The biological roots of crime. Londyn: Penguin

Reitz, K. R. (2011). Sentencing. W: J. Q. Wilson, J. Petersilia (red.), Crime and public policy (s. 467-498). Nowy Jork: Oxford University Press.

Romi, S., Marom, D. (2007). Differences in intelligence between non delinquent and dropout 636 delinquent adolescents. Adolescents, 42, 325-336.

Royall, D. R., Lauterbach, E. C., Cummings, J. L., Reeve, A., Rummans, T. A., Kaufer, D. I., ..., Coffey, C. E. (2002). Executive control function: A review of its promise and challenges for clinical research. A report from the Committee on Research of the American Neuropsychiatric Association. The Journal of Neuropsycbiatry and Clinical Neurosciences, 14(4), 377-405. https://doi.org/10.1176/jnp.14.4.377

Rubia, K. (2011). „Cool” inferior frontostriatal dysfunction in Attention-Deficit/ Hyperactivity Disorder versus „hot” ventromedial orbitofrontal-limbic dysfunction in conduct disorder: A review. Biological Psychiatry, 69(12), 69-87. https://doi. org/10.1016/j.biopsych.2010.09.023

Schwartz, J. A., Savolainen, J., Aaltonen, M., Merikukka, M., Paananen, R., Gissler, M. (2015). Intelligence and criminal behavior in a total birth cohort: An examination of functional form, dimensions of intelligence, and the nature of offending. Intelligence, 51, 109-118. https://doi.org/10.1016/j.intell.2015.06.001 
Snow, P. C., Powell, M. B. (2011). Oral language competence in incarcerated young offenders: Links with offending severity. International Journal of Speech-Language Pathology, 13(6), 480-489. https://doi.org/10.3109/17549507.2011.578661

Stattin, H., Klackenberg-Larsson, I. (1993). Early language and intelligence development and their relationship to future criminal behavior. Journal of Abnormal Psychology, 102(3), 369-378. https://doi.org/10.1037/0021-843X.102.3.369

Sternberg, R. J. (2005). Intelligence. Cambridge: Cambridge University Press.

Stuss, D. T., Alexander, M. P. (2000). Executive functions and the frontal lobes: A conceptual view. Psychological Research, 63(3), 289-298. https://doi.org/10.1007/ s004269900007

Stuss, D. T., Levine, B. (2002). Adult clinical neuropsychology: Lessons from studies of the frontal lobes. Annual Review of Psychology, 53(1), 401-433. https://doi. org/10.1146/annurev.psych.53.100901.135220

Sutherland, E. H. (1931). Mental deficiency and crime. W: K. Young (red.), Social attitudes (s. 357-375). Philadelphia: Winston.

Sutherland, E. H. (1985). White collar crime: The uncut version. Nowy Jork: Yale University Press.

Ttofi, M. M., Farrington, D. P., Piquero, A. R., Lösel, F., DeLisi, M., Murray, J. (2016). Intelligence as a protective factor against offending: A meta-analytic review of prospective longitudinal studies. Journal of Criminal Justice, 45, 4-18. https://doi. org/10.1016/j.jcrimjus.2016.02.003

Tuominen, T., Korhonen, T., Hämäläinen, H., Temonen, S., Salo, H., Katajisto, J., Lauerma, H. (2014). Neurocognitive disorders in sentenced male offenders: Implications for rehabilitation. Criminal Behaviour and Mental Health, 24(1), 36-48. https://doi.org/10.1002/cbm.1879

Vieraitis, L. M., Copes, H., Powell, Z. A., Pike, A. (2015). A little information goes a long way: Expertise and identity theft. Aggression and Violent Behavior, 20, 10-18. https:// doi.org/10.1016/j.avb.2014.12.008

Wallinius, M., Delfin, C., Billstedt, E., Nilsson, T., Anckarsäter, H., Hofvander, B. (2016). Offenders in emerging adulthood: School maladjustment, childhood adversities, and prediction of aggressive antisocial behaviors. Law and Human Behavior, 40(5), 551-563. https:// doi.org/10.1037/lhb0000202

Werner, E. E., Smith, R. S. (1982). Vulnerable but invincible: A longitudinal study of resilient children and youth. Nowy Jork: McGraw-Hill Book Company.

Wilson, J. Q., Herrnstein, R. J. (1985). Crime and human nature: The definitive study of the causes of crime. Nowy Jork: The Free Press.

Wong, S. (1985). Criminal and institutional behaviours of psychopaths. Ottawa: Ministry of the Solicitor General of Canada. 
Iwona Nowakowska (iD https://orcid.org/0000-0001-7701-5612

Akademia Pedagogiki Specjalnej im. Marii Grzegorzewskiej w Warszawie, Instytut Psychologii

i.en.nowakowska@gmail.com

Karolina Lewandowska (iD https://orcid.org/0000-0002-1491-911X

Uniwersytet Kardynała Stefana Wyszyńskiego w Warszawie, Instytut Psychologii

Karol Lewczuk iD https://orcid.org/0000-0003-2437-2450

Uniwersytet Kardynała Stefana Wyszyńskiego w Warszawie, Instytut Psychologii 


\section{WPROWADZENIE}

Uzależnienia (nałogi) to, w potocznym rozumieniu, wzory zachowania, które objawiają się silną tendencją do, i nawracająca potrzeba, zażywania jakiejś substancji bądź wykonania określonego zachowania. Zauważając u siebie określony silny nawyk, ktoś może powiedzieć: „Jestem uzależniony/a od (np.) kawy. Nie mogę wyjść z domu bez przynajmniej jednego kubka”. Możemy spotkać się z kimś, kto sam twierdzi o sobie, że jest w pewnym sensie uzależniony np. od Internetu czy Facebooka. Powszechnie znane są również konsekwencje uzależnień np. od alkoholu czy narkotyków. Według definicji psychologicznej, używanej także na potrzeby praktyki terapeutycznej, nałogi to charakterystyczne zaburzenia, mające szereg daleko idących konsekwencji, które wpływają na obniżenie jakości funkcjonowania - również intelektualnego - w codziennym życiu (np. Chamberlain, Grant, 2019). Aby dobrze zrozumieć naturę zachowań nałogowych, tak jak definiowane są formalnie w psychologii i psychiatrii, warto odwołać się do sześciu kryteriów stanowiących ich cechy charakterystyczne: (1) zdominowaniu życia osoby przez daną aktywność (salience); (2) euforii (euphoria) - intensywnego odczucia emocjonalnego związanego z zachowaniem nałogowym; (3) tolerancji - osoba musi podejmować zachowanie z coraz większą częstotliwością, by osiąnąć ten sam efekt pobudzenia; (4) objawów odstawiennych (withdrawal symptoms) - zaprzestanie aktywności powoduje pojawienie się nieprzyjemnych emocji lub objawów z ciała; (5) konfliktu (conflict) - aktywność prowadzi do konfliktów z innymi osobami lub konfliktu wewnętrznego; (6) nawrotowości - próby abstynencji czy zaprzestania zachowania kończą się powrotem do danej aktywności z tą samą siłą co przedtem (Charlton, 2002; Grant, Chamberlain, 2014; Griffiths, 1996).

Pierwotnie wyżej wymienione kryteria definicyjne stosowane były wobec uzależnień od substancji (takich jak nikotyna, alkohol, narkotyki, kofeina). Jednakże współcześnie uważa się, że kryteria te da się trafnie zastosować nie tylko w kontekście substancji, ale też w odniesieniu do innych zachowań, które moga tak samo łatwo wymykać się spod kontroli i mieć uzależniająca naturę. Takie uzależnienia nazywa się obecnie uzależnieniami behawioralnymi (behavioral addictions; Leeman, Potenza, 2013). 
W uzależnieniach od substancji dysfunkcje poznawcze były przedmiotem licznych badań, szczególnie w ostatnich 20 latach. Badania te dostarczyły dowodów na to, że zmienione funkcjonowanie poznawcze jest charakterystyczną cechą zaburzeń związanych z nadużywaniem środków psychoaktywnych (Ramey, Regier, 2019). Czy podobne zależności daje się zaobserwować w przypadku uzależnień behawioralnych?

Celem niniejszego rozdziału jest opisanie wybranych aspektów funkcjonowania poznawczego, które mogą być zmienione, najczęściej ulegając pogorszeniu, u osób przejawiających objawy wybranych uzależnień behawioralnych. Pierwsza część tekstu będzie skupiona na przedstawieniu krótkiej charakterystyki nałogów behawioralnych w świetle badań naukowych. W kolejnej omówione zostana pokrótce najważniejsze pojęcia związane z funkcjonowaniem poznawczym człowieka (iloraz inteligencji, inteligencja emocjonalna, funkcje wykonawcze), które są najczęściej badane w kontekście uzależnień i mogą mieć znaczenie w procesie ich rozwoju i utrzymywania się. Najważniejsza część tekstu dotyczyć będzie funkcjonowania poznawczego w wybranych uzależnieniach behawioralnych: od hazardu, Internetu, gier wideo (np. gier komputerowych), zakupów oraz zachowań nałogowych związanych z aktywnością seksualna. W podsumowaniu przedstawione zostaną również przedstawione najważniejsze kierunki przyszłych badań.

\section{CZY MOŻNA SIĘ UZALEŻNIĆ OD ZACHOWANIA? PROBLEM NAŁOGÓW BEHAWIORALNYCH}

Nałogi (uzależnienia) behawioralne, w odróżnieniu od uzależnień od substancji, obejmuja grupę zaburzeń, dla których przedmiotem bezpośredniego uzależnienia sa zachowania, a nie chemiczna substancja psychoaktywna (zob. np. Grant, Potenza, Weinstein, Gorelick, 2010). Idea nałogów behawioralnych oparta jest na założeniu, że zaangażowanie w określone zachowania, tak samo jak przyjmowanie niektórych substancji, może mieć gratyfikującą naturę i przez to powodować wytworzenie silnej tendencji do powtarzania tych zachowań, w ostateczności prowadząc również do utraty kontroli nad nimi i podejmowania ich mimo świadomości ryzyka bądź negatywnych konsekwencji dla siebie i otoczenia. Założenie to jest równocześnie definicyjnym kryterium zaburzeń nałogowych w ogóle (Demetrovics, Griffiths, 2012; Grant i in., 2010; Karim, Chaudhri, 2012; Robbins, Clark, 2015). Pogłębiona i szeroka dyskusja nad tym, czy zachowania mogą być przedmiotem nałogu, rozpoczęła się jednak dosyć niedawno - bo na przełomie wieków - dzięki głośnej i szeroko komentowanej 
pracy Holden (2001), opublikowanej w Science. Stosunkowo niedługi czas, który minął od publikacji cytowanej pracy, to jednak okres bardzo szybkiego rozwoju badań w tym obszarze psychologii, dzięki czemu uzależnienia behawioralne (w różnych formach) są dziś jednostkami diagnostycznymi proponowanymi do obowiązujących klasyfikacji zaburzeń (American Psychiatric Association [APA], 2013; Grant, Chamberlain, 2016; World Health Organization [WHO], 2019). Obecnie bada się bardzo dużo różnorodnych typów zachowań, które mogą być potencjalnie uzależniające - np. hazard, aktywność w Internecie, granie w gry wideo, zakupy, zachowania seksualne, ćwiczenia fizyczne, praca, nauka, korzystanie ze smartfona (np. Andreassen $\mathrm{i}$ in., 2013; Billieux, Schimmenti, Khazaal, Maurage, Heeren, 2015).

Ze względu na to, że koncepcja uzależnień behawioralnych jest dość nowa, jest też mało rozpowszechniona w polskiej literaturze naukowej. Widoczne sa również braki w danych na temat rozpowszechnienia nałogów behawioralnych w Polsce (analiza dostępnych danych na temat naszego kraju i wyżej wymienionych braków w literaturze dostępna w: Nowakowska, Lewczuk, Gola, 2020). Jedynymi dostępnymi badaniami prowadzonymi na reprezentatywnej populacji polskiej są raporty Centrum Badań Opinii Społecznej z badań przeprowadzonych w 2012, 2014 i 2019 roku, które dostarczyły informacji na temat rozpowszechnienia uzależnień od hazardu, Internetu, kupowania oraz pracy (Badora, Gwiazda, Herrmann, Kalka, Moskalewicz, 2015; Moskalewicz i in., 2019). Według tych badań najwięcej osób przejawiało objawy uzależnienia od pracy (10,4\% populacji ogólnej w 2012 r.; 19,1\% w 2014 r.; 9,1\% w 2019 r.), następnie kompulsywnych zakupów (3,5\% w 2012r.; 4,1\% w 2014 r.; 3,7\% w 2019 r.), hazardu (0,2\% grających problemowo w 2012 r.; 0,7\% w 2015 r.; 0,9\% w 2019 r.); Internetu ( $0,2 \%$ z uzależnieniem w 2012 r.; 0,1\% z w 2014 r.; 0,03\% w 2019 r.). Najnowsze badanie rozpowszechnienia nałogów behawioralnych w Polsce (Moskalewicz i in., 2019) objęło ponadto uzależnienia od mediów społecznościowych oraz telefonu (fonoholizm). Według niego 1,1\% populacji Polaków wykazywało symptomy uzależnienia od mediów społecznościowych, a 7,8\% - objawy fonoholizmu.

Autorzy niniejszego rozdziału wraz ze współpracownikami (Lewczuk, Nowakowska, Lewandowska, Potenza, Gola, 2021) w 2019 roku przeprowadzili również badania własne nad rozpowszechnieniem wybranych uzależnień behawioralnych na reprezentatywnej próbie Polaków $(N=1036)$. Według nich 5,9\% Polaków określało się jako osoby przynajmniej w pewnym stopniu uzależnione od pornografii, 23\% - od Internetu, 13,3\% - od sieci społecznościowych, $4,2 \%$ - od gier wideo. Należy jednak wziąć pod uwage, że badanie to po- 
legało na samodiagnozie, tj. uczestnicy samodzielnie określali, czy uważają się za osoby uzależnione od danej aktywności, odpowiadając na pytanie „Jestem uzależniony/a od..." (przy tworzeniu powyższych współczynników zostały wzięte pod uwagę odpowiedzi od raczej sie zgadzam do zdecydowanie sie zgadzam). Należy też pamiętać, że dane uzyskane dzięki takim deklaracjom z natury różnią się od danych uzyskiwanych z zastosowaniem wystandaryzowanych kwestionariuszy przesiewowych, które opisywane były wyżej (Moskalewicz i in., 2019). Dane na temat rozpowszechnienia nałogów behawioralnych w Polsce są więc dostępne, ale fragmentaryczne.

Przeprowadzenie kolejnych badań, wykorzystujących rzetelne narzędzia diagnostyczne wydaje się być ważną potrzebą w związku z relatywnie dużym odsetkiem osób samodiagnozujących się jako uzależnione, ale także w związku z częściowym rozpoznaniem uzależnień behawioralnych w najnowszych klasyfikacjach diagnostycznych. Specjaliści dyskutowali nad włączeniem zachowań nałogowych do takich klasyfikacji i w ostateczności niektóre z nich stały się częścią ich najnowszych wydań. W DSM-5 (APA, 2013), klasyfikującym zaburzenia psychiczne i używanym głównie przez praktyków w Stanach Zjednoczonych oraz naukowców, można odnaleźć jednostkę diagnostyczną hąard patologiczny. W drugiej wiodącej światowej klasyfikacji chorób, w tym zaburzeń psychicznych, ICD-11 (WHO, 2019), używanej przez praktyków poza USA oraz badaczy, również znajduje się jednostka związana z problemami z hazardem, ale także zaburzenie związane z graniem w gry (w tym w Internecie) oraz kompulsywne zachowania seksualne (manifestujące się poprzez - jak sądzi wielu badaczy - uzależnienie od zachowań seksualnych; zobacz dyskusję w: Kraus, Voon, Potenza, 2016).

Biorąc pod uwagę toczące się dyskusje nad klasyfikacjami diagnostycznymi oraz dostępne badania na temat funkcjonowania poznawczego w uzależnieniach, w niniejszym rozdziale zdecydowaliśmy się na omówienie funkcji poznawczych istotnych dla rozwoju oraz podtrzymywania symptomów nałogowych, a następnie specyficznej charakterystyki funkcjonowania poznawczego w pięciu wybranych nałogach behawioralnych: związanych z hazardem, Internetem ogólnie, grami internetowymi, zakupami oraz aktywnością seksualną.

\section{JAKIEGO RODZAJU WIEDZA O FUNKCJONOWANIU POZNAWCZYM MOŻE POMÓC W ZROZUMIENIU NAŁOGÓW?}

Inteligencja jest bardzo ogólną zdolnością umysłową człowieka, umiejętnościa rozumowania, planowania, rozwiązywania problemów, myślenia abs- 
trakcyjnego, pojmowania złożonych idei i szybkiego uczenia się (również na podstawie doświadczeń). Nie jest wiedzą akademicką, ani też umiejętnością rozwiązywania testów (Gottfredson, 1997). Stern przedstawiał inteligencję jako zdolność adaptacji do nowych warunków i zadań, Ferguson natomiast - jako zdolność uczenia się (przeglądu najważniejszych konceptualizacji dokonała np. Tyszkowska, 2017). Pojęcie inteligencji bywa także definiowane jako zasób narzędzi poznawczych dostępnych jednostce (Chuderski, 2019; Chuderski, Nęcka, 2010; Czerniawska, 2006; Sternberg, 2000). Za najbardziej typowe przejawy inteligencji uważa się zdolności rozumowania i wnioskowania (Binet, Simon, 1916; Spearman, 1925; Truszczyński, Różanowski, Baran, Lewandowski, 2012), zdolność logicznego i abstrakcyjnego myślenia, a także planowania i rozwiązywania problemów. Pionierska teoria Spearmana (1925) wprowadziła pojęcie czynnika $g$ - nadrzędnej, ogólnej właściwości umysłowej. W późniejszych latach rozwijano tę teorię i wprowadzano także inne rozróżnienia rodzajów inteligencji, odpowiadających za różne procesy umysłowe. Jedną z wiodących teorii tego typu była teoria Cattella (1972), który opisywał inteligencję płynną, zależną od czynnika genetycznego, a szczególnie od charakterystyki układu nerwowego, oraz inteligencję skrystalizowaną, kształtowaną w efekcie uczenia się, nabywania wiedzy i umiejętności (Truszczyński i in., 2012). Inteligencja płynna stanowi więc pewien wrodzony potencjał intelektualny jednostki, podczas gdy inteligencja skrystalizowana powstaje w wyniku interakcji tego potencjału z doświadczeniem życiowym i zdobyta wiedza (Tomorowicz, 2011) i oznacza umiejętne wykorzystanie tej wiedzy (Pajestka, Skałacka, Wirga, 2018). Do pomiaru inteligencji w każdym jej wymiarze wykorzystywane sa wystandaryzowane testy psychologiczne. Dotychczas przeprowadzone badania wskazuja na ujemny związek poziomu inteligencji z nałogami behawioralnymi, szczególnie uzależnieniem od Internetu. Nałogi behawioralne, według badań, nierzadko współwystępują z pogorszeniem funkcjonowania poznawczego (Park i in., 2011). Dokładne informacje na temat charakterystyki funkcjonowania poznawczego w wybranych nałogach behawioralnych zawierać będa kolejne podrozdziały.

Innym ważnym konstruktem, który może pomóc w zrozumieniu natury uzależnień, jest inteligencja emocjonalna. Można ją zdefiniować jako zdolność do obserwowania i rozróżniania uczuć i emocji własnych oraz innych osób, a także do używania zdobytej poprzez tę obserwację wiedzy do kierowania swoim myśleniem i zachowaniem (Salovey, Mayer, 1990). Niektórzy badacze argumentuja, że inteligencja emocjonalna jest tak samo istotna w codziennym życiu, jak inteligencja ogólna (Cotruş, Stanciu, Bulborea, 2012; Ema- 
nuel, Gudbranson, 2018). Jej znaczenie w sukcesie szkolnym i zawodowym (np. Newman, Joseph, MacCann, 2010; O’Boyle, Humphrey, Pollack, Hawver, Story, 2011; Parker i in., 2004; Vandervoort, 2006), a także utrzymaniu zdrowia i dobrostanie jest udokumentowany licznymi badaniami (np. Austin, Saklofske, Egan, 2005; Extremera, Fernàndez-Berrocal, 2005; Martins, Ramalho, Morin, 2010; Tsaousis, Nikolaou, 2005). Systematyczny przegląd badań Kun i Demetrovicsa (2010) wskazał na to, że umiejętności rozpoznawania, wyrażania i regulowania emocji są ściśle związane zarówno z uzależnieniami od substancji, jak i behawioralnymi. Istnieją hipotezy, że uzależnienia od substancji mają charakter nieadaptacyjnego radzenia sobie w sytuacjach życiowych, między innymi ze stresem oraz emocjami (Garland i in., 2018; Kober, 2014). Niska inteligencja emocjonalna, trudności w rozpoznawaniu i radzeniu sobie ze swoimi stanami psychicznymi mogą więc stanowić istotny czynnik ryzyka zaangażowania w zachowania nałogowe.

W badaniach nad funkcjonowaniem poznawczym, prócz inteligencji ogólnej i emocjonalnej, szczególnie ważne wydają się być procesy związane z kontrolą poznawczą. Kontrola poznawcza pozwala osobie zarządzać własnym zachowaniem (Brand, Young, Laier, 2014; Brand, Young, Laier, Wölfling, Potenza, 2016), obserwować i regulować procesy myślowe, a także planować i kontrolować ich przebieg (Nęcka, Orzechowski, Szymura, 2006). Przejawia się w sprawnym przystosowywaniu się do wymagań środowiska oraz selekcji odpowiednich informacji przy podejmowaniu decyzji.

Procesy kontroli poznawczej odpowiedzialne za skomplikowane, świadome $\mathrm{i}$ inteligentne zachowania nazywamy funkcjami wykonawczymi (Diamond, 2013; Nęcka i in., 2006). Wśród funkcji wykonawczych wymienić możemy kilka szczególnie istotnych dla rozwoju i podtrzymywania uzależnień: (1) monitorowanie napływających informacji, (2) koncentrowanie uwagi, (3) utrzymywanie danych w pamięci roboczej, korzystanie z nich oraz ich aktualizowanie, (4) zdolności podejmowania decyzji, (5) hamowanie reakcji, (6) elastyczność poznawczą (np. Friedman, Miyake, 2017; Goudriaan, Oosterlaan, de Beurs, van den Brink, 2006; Miyake i in., 2000; Ramey, Regier, 2019).

Monitorowanie napływających informacji odpowiada za obserwowanie środowiska oraz tego, co się w nim dzieje. Ważna wydaje się być tutaj rola pamięci roboczej. Pamięć robocza (working memory) to jeden z systemów pamięci ludzkiej przechowujący oraz przetwarzający informacje w krótkim czasie. Informacje te są gromadzone tylko na użytek teraźniejszości, tak, aby mogły zostać natychmiastowo wykorzystane (Baddeley, 1992; Baddeley, Logie, 1999). Korzystanie $z$ danych przechowywanych w pamięci roboczej 
oraz ich aktualizowanie jest niezbędne, by w jak najbardziej efektywny i przemyślany sposób podejmować decyzje co do zachowania (Bechara, Martin, 2004; Hinson, Jameson, Whitney, 2003). Istotne jest tutaj również utrzymanie koncentracji uwagi na odpowiednich bodźcach. W uzależnieniach istotna rolę odgrywają bodźce z otoczenia, które moga zachęcać do podejmowania danej problematycznej aktywności. Kiedy osoba ulega nałogowi pod wpływem takich bodźców (podejmując impulsywną decyzję), badacze nazywają to zjawisko reaktywnością na wskazówki (cue-reactivity; Carter, Tiffany, 1999). Aby lepiej zrozumieć mechanizm impulsywnego, nieprzemyślanego angażowania się w zachowania pod wpływem wskazówek, istotne wydaje się badanie bardzo istotnej dla uzależnień funkcji wykonawczej, jaką jest hamowanie reakcji. Hamowanie reakcji ma związek tendencją do impulsywnych zachowań w odpowiedzi na bodźce (response inbibition, impulsive action), ale także - do impulsywnych wyborów (impulsive choice; Grant, Chamberlain, 2014).

Tendencję do impulsywnych zachowań można zdefiniować jako nieumiejętność powstrzymania się od danego zachowania pomimo wskazówek z otoczenia. W laboratorium hamowanie odpowiedzi na bodźce najczęściej badane jest poprzez zadania, w których wymagane jest wykonanie prostej czynności, gdy na monitorze pojawia się określony bodziec-sygnał. Przykładowo osoba badana ma za zadanie powstrzymać się od intuicyjnej reakcji, naciskając określony przycisk na klawiaturze, np. strzałkę w prawo, gdy na monitorze pojawiają się dystraktory sugerujące inną odpowiedź (np. strzałki skierowane w lewo), co utrudnia szybką i poprawną reakcję, jak w tzw. zadaniu flankerów (Eriksen, Eriksen, 1974). Niekiedy używa się także zadań, w których osoba najpierw uczy się kojarzyć wskazówkę z określoną reakcją ruchową, a następnie musi powstrzymać się od tej wyuczonej, nawykowej reakcji w sytuacji pojawienia się określonego sygnału (Eagle, Bari, Robbins, 2008; Logan, Cowan, 1984; Schachar i in., 2007). Takie zadania nazywają się go-no go (gdy wskazówka wstrzymująca pojawia się razem z mającą wywołać reakcję) lub stop-signal task, gdy wskazówka wstrzymująca wyświetla się osobno od wywołującej reakcję (Grant, Chamberlain, 2014). W praktyce tendencja do impulsywnych zachowań może powodować, jak wspomniano wyżej, uleganie nałogowi pod wpływem wskazówek oraz trudności w utrzymaniu abstynencji.

Tendencja do impulsywnych wyborów jest również bardzo ważna w rozumieniu mechanizmów powstawania i utrzymywania nałogów. Jest ona związana z wybieraniem mniejszych, natychmiastowych nagród (gratyfikacji) zamiast większych, długoterminowych korzyści (Cardinal, Pennicott, Lakmali, Robbins, Everitt, 2001; Evenden, 1999; Shamosh i in., 2008). Wybór większej, 
ale odroczonej w czasie nagrody wymaga zdolności do kontroli poznawczej, a w szczególności hamowania intuicyjnej reakcji sięgnięcia po natychmiastową nagrodę. Obniżoną zdolność do tak rozumianego odraczania gratyfikacji obserwuje się w praktyce w przypadku osób, które przykładowo nieskutecznie próbuja utrzymać abstynencję. W badaniach laboratoryjnych, które maja na celu uzyskanie lepszego wglądu w tego rodzaju mechanizmy nagrodami, mogą być prawdziwe pieniądze lub abstrakcyjne punkty w zadaniach (Grant, Chamberlain, 2014). Otrzymywanie gratyfikacji podlega warunkowaniu (Banca $\mathrm{i}$ in., 2016; Klucken, Wehrum-Osinsky, Schweckendiek, Kruse, Stark, 2016; Snagowski, Laier, Duka, Brand, 2016), co oznacza, że osoba uczy się, że dane zachowania prowadzą do osiągania przyjemności. W takiej sytuacji zwiększona aktywność mózgowego układu nagrody, w szczególności brzusznego prążkowia, odpowiada za pojawienie się głodu nałogowego oraz ogólnie symptomów przypominających uzależnienie (Brand, Snagowski, Laier, Maderwald, 2016; Gola, Wordecha, Marchewka, Sescousse, 2016; Gola i in., 2017). W życiu osoby uzależnionej tendencja do impulsywnych wyborów wiąże się z trudnościami w ograniczeniu problematycznych zachowań. Przejawiać się to może preferencją sięgnięcia po określoną substancję bądź zaangażowania w określone zachowania celem uzyskania chwilowej przyjemności zamiast powstrzymania impulsywnej reakcji, co przełożyłoby się na długofalową korzyść związaną z abstynencja.

Elastyczność poznawcza (cognitive flexibility) to zdolność do przystosowania strategii działania do nowych, zmieniających się i nieprzewidywalnych warunków środowiskowych (Cañas, Quesada, Antolí, Fajardo, 2003). Strategie poznawcze są w tej definicji sekwencjami operacji wymaganymi do rozwiązania danego problemu (Payne, Payne, Bettman, Johnson, 1993). Przeciwieństwem elastyczności poznawczej jest sztywność poznawcza (cognitive rigidity). Przykładem niskiej elastyczności (sztywności) poznawczej jest np. podejmowanie działań, które uprzednio były efektywne, jednak po zmianie wymogów sytuacji okazują się bezużyteczne, a mimo tego wciąż są stosowane. W warunkach laboratoryjnych elastyczność definiuje się jako łatwość przełączania się z jednego zadania/celu na drugi (Goschke, Bolte, 2014) i bada się poprzez zadania wymagające tego rodzaju aktywności, tzw. set/task switching tasks. Elastyczność obejmuje zarówno wstrzymywanie się od dążenia do nieaktualnych celów (co sugeruje podobieństwo, ale nie tożsamość z opisanym wyżej hamowaniem reakcji; Morris, Mansell, 2018), jak również przełączanie się między zadaniami w odpowiedzi na zmieniające się wymagania (Meiran, 2010; Miyake i in., 2000). Brak elastyczności poznawczej może owocować nieskutecznością terapii uza- 
leżnienia, jako że osobie którą charakteryzuje sztywność poznawcza, trudno jest zmienić swoje dotychczasowe zachowanie. Na przykład w odpowiedzi na stresujące sytuacje wciąż używa ona nieefektywnych strategii radzenia sobie z odczuwanym napięciem, takich jak zachowanie nałogowe.

\section{FUNKCJONOWANIE POZNAWCZE W WYBRANYCH UZALEŻNIENIACH BEHAWIORALNYCH}

Patologiczny hazard. Hazard patologiczny (przedstawiany w literaturze także jako patologiczne uprawianie hazardu i/lub zakładanie się, hazard nałogowy, hazard kompulsywny) to zaburzenie zdefiniowane medycznie, ujęte w klasyfikacjach diagnostycznych i występujące zarówno w klasyfikacji zaburzeń psychicznych DSM-5 (APA, 2013), jak i w ICD-11 (WHO, 2019). W klasyfikacji DSM-5 po raz pierwszy potraktowano zaburzenia uprawiania hazardu jako nałóg behawioralny, umieszczając je w grupie zaburzeń związanych z substancjami (psychoaktywnymi) i zaburzeń nałogowych (substance-related and addictive disorders; Silczuk, Habrat, 2016). Zgodnie z DSM-5, zaburzenia związane $z$ uprawianiem hazardu to utrwalone i nawracające nieadaptacyjne zachowania towarzyszące uprawianiu hazardu, ujawniające się przez brak zdolności do kontrolowania się w czasie grania, co w efekcie prowadzi do negatywnych konsekwencji i strat osobistych, rodzinnych oraz zawodowych, finansowych i prawnych (APA, 2013).

Liczne dane świadczą o tym, że uprawianie hazardu w sposób patologiczny może dotykać osoby cechujące się wysoką impulsywnością. W badaniu Shenassy i wspólpracowników (Shenassa, Paradis, Dolan, Wilhelm, Buka, 2012) wykazano, że dzieci, u których do 7. roku życia stwierdzono wysoką impulsywność, w dorosłości miały trzykrotnie częściej problemy związane z uprawianiem hazardu (Shenassa i in., 2012). Podobnie osoby posiadające diagnozę ADHD (attention-deficit hyperactivity disorder, zespól nadpobudliwości psychoruchowej z deficytem uwagi), które jest związane z impulsywnym reagowaniem, w wieku dorosłym częściej przejawiały zaburzenia hazardowe (Breyer i in., 2009).

W myśl wyników badań naukowych zaburzenia uprawiania hazardu wiążą się z pogorszeniem funkcjonowania poznawczego. Ostatnie badania wskazują na występowanie selektywnej dysfunkcji poznawczej nawet na niższych poziomach patologii hazardu, gdy gracze nie spełniają wszystkich kryteriów zaburzeń hazardowych (Chamberlain, Stochl, Redden, Odlaug, Grant, 2017). W porównaniu z grupa kontrolną hazardziści osiagają słabsze wyniki w testach 
mierzących poziom inteligencji (Martinez-Pina i in., 1991), szczególnie inteligencji werbalnej (słownej; Forbush i in., 2008). Inne badania wykazały, że nastolatki doświadczające problemów w uczeniu się narażone są na zaburzenia hazardowe dużo bardziej niż ich rówieśnicy, którzy nie doświadczają trudności w nauce (McNamara, Vervaeke, Willoughby, 2008; Taylor, Parker, Keefer, Kloosterman, Summerfeldt, 2015). Przeprowadzone do tej pory badania naukowe na temat związków inteligencji oraz hazardu dostarczaja jednak wstępnych wyników, co powoduje, że nie jest możliwe, by w jednoznaczny sposób orzekać o tym, czy niski poziom inteligencji ogólnej skutkuje wyższą podatnością na tego rodzaju uzależnienie.

Zniekształcenia poznawcze oraz błędne przekonania w związku $\mathrm{z}$ oceną realnych szans na wygraną $i$ wynikające $z$ nich zachowania odgrywają zasadniczą rolę w rozwoju i podtrzymaniu problemowych zachowań hazardowych (Clark, 2010; Hahmann, 2016). Często tego typu przekonania (np. zbyt optymistyczna ocena własnych szans na wygrana) służą jako uzasadnienia nadmiernej gry przed innymi osobami. Podczas jednego z eksperymentów Gaboury i Ladouceur (1989) poprosili regularnych graczy, by wypowiadali na głos wszystkie aktualne myśli, jakie pojawiają się w trakcie grania. Blisko 70\% wypowiedzi na temat strategii gry było błędnych i nieracjonalnych. Badani przypisywali maszynom cechy osobowości, a ich zachowanie miało rys powtarzalnego rytuału. Wyrażali oni także przekonanie o zdobywaniu umiejętności w grach, które miały czysto losowy charakter (a więc nie da się w nich zwiększyć swojej skuteczności). Takie zachowanie może wynikać również z trudności w procesie przetwarzania informacji (Clark, 2010; Silczuk, Habrat, 2016). Zasadnicze zniekształcenia poznawcze u osób uprawiających hazard w sposób patologiczny dotyczą złudnego poczucia kontroli nad wynikiem gry oraz przesądnego przekonania o szczęściu, ponadto wiążą się z brakiem zdolności rozumienia niezależności zdarzeń losowych (Taylor i in., 2015). Problemowi gracze błędnie przypisują wygrane czynnikom wewnętrznym, takim jak przekonanie o zdobytych umiejętnościach czy przesądne zachowania rytualne, podczas gdy wyjaśnienie porażek i strat lokują w czynnikach zewnętrznych (Nicholson, Graves, Ellery, Afifi, 2016). Jest to spójne z założeniem, według którego gracze o zewnętrznym umiejscowieniu kontroli częściej staja się graczami problemowymi w porównaniu z osobami o silnym, wewnętrznym umiejscowieniu kontroli (Gong, Zhu, 2019).

Również obniżony poziom inteligencji emocjonalnej wiąże się z wyższym ryzykiem wystapienia zaburzeń hazardowych (Kaur, Schutte, Thorsteinsson, 2006). Słabsza identyfikacja emocji i gorsze ich rozumienie oraz trudności 
w regulowaniu emocji, zwłaszcza podczas podejmowania decyzji mogą przyczyniać się do rozwoju problemów hazardowych. Co ważne, wyższy poziom inteligencji emocjonalnej wiąże się ze skuteczną kontrolą impulsów (Schutte i in., 1998). Niska inteligencja emocjonalna może więc skutkować zmniejszoną skutecznością kontroli uprawiania hazardu i tym samym większą liczbą problemów z hazardem (May, Whelan, Steenbergh, Meyers, 2003). Co interesujące, wśród zawodowych graczy w pokera inteligencja emocjonalna okazała się być dużo lepiej rozwinięta w porównaniu z osobami niegrającymi w tę grę. Trudno o jednoznaczne określenie kierunku tej zależności - czy gracze o już rozwiniętej inteligencji emocjonalnej podejmuja grę w pokera i w efekcie odnoszą większe sukcesy, czy też wyższa inteligencja emocjonalna wynika $z$ wieloletniego grania, które ukształtowało umiejętność odczytywania cudzych emocji (Muda, Śliwińska, Pawelec, 2014). W literaturze podkreśla się główny cel uprawiania hazardu, jakim jest poprawa nastroju. Osoby przejawiające zaburzenia hazardowe opisywane są także jako poszukujące silnych wrażeń (Blaszczyński, Nower, 2002; Sharpe, 2002), co może według niektórych badaczy sugerować trudności w związku z regulacją pozytywnych emocji (Rogier, Velotti, 2018).

Towarzysząca wygranej silna stymulacja sensoryczna pod postacią migających świateł i głośnych dźwięków automatów ułatwia przypominanie sobie sukcesów i nagród, podczas gdy wspomnienia strat ulegają stępieniu. Wpływa to na decyzję o kontynuowaniu gry (Clark, 2010) i jest objawem jednego ze zniekształceń poznawczych, tj. wybiórczości pamięci. Wysoka reaktywność na sygnały związane $z$ hazardem prowadzi do trudności w ocenie prawdopodobieństwa i podjęciu najkorzystniejszej decyzji (Parke, Harris, Parke, Goddard, 2016).

Osoby dotknięte zaburzeniami uprawiania hazardu przejawiaja osłabienie kontroli impulsów pod postacią upośledzonego hamowania odpowiedzi (Forbush i in., 2008) i słabej samoregulacji oraz wysoką wrażliwość na nagrody i kary. Deficyty samoregulacji, objawiające się jako uporczywe angażowanie się w zachowania hazardowe pomimo negatywnych konsekwencji, maja związek $z$ rozregulowaniem struktur przetwarzających informacje o nagrodzie (Parke i in., 2016). Wyniki najnowszych badań wskazują na upośledzenie funkcji wykonawczych wśród problemowych graczy, a szczególnie pamięci roboczej (Forbush i in., 2008; Mallorquí-Bagué i in., 2018), elastyczności poznawczej oraz umiejętności zarządzania czasem (Mallorquí-Bagué i in., 2018), co może wynikać z faktu, że gracze cechują się tendencją do przestrzegania sztywnych zasad (Broussard, Wulfert, 2019), popełniają także więcej błędów perseweracyjnych, tj. nie potrafią zmienić sposobu rozumowania i działania mimo 
zmieniających się warunków i informacji napływających z otoczenia. Gracze problemowi i patologiczni wykazują deficyty w efektywności podejmowania decyzji. Przykładowo podczas wykonywania laboratoryjnego zadania decyzyjnego ryzykowali więcej punktów, podejmowali bardziej irracjonalne decyzje i wykazywali większą skłonność do bankructwa (Chamberlain i in., 2017).

Co ważne, nie wszystkie osoby dotknięte zaburzeniem uprawiania hazardu wykazuja jednakowe nasilenie wyżej wymienionych deficytów poznawczych. Ponadto wstępne obserwacje badaczy sugerują istnienie podtypów zaburzeń hazardowych, charakteryzujących się jakościowo różnymi symptomami towarzyszącymi problematycznemu graniu, ale do tej pory nie zostały one jasno wyodrębnione (Mallorquí-Bagué i in., 2018).

\section{UZALEŻNIENIE OD INTERNETU}

Uzależnienie od Internetu pojawiało się w dyskusjach nad klasyfikacjami psychiatrycznymi od lat '90 XX wieku (Young, 1996). Tao i in. (2010) zaproponowali następujące kryteria diagnozy uzależnienia od Internetu: zaabsorbowanie Internetem, symptomy odstawienia, zwiększająca się tolerancja na korzystanie z Internetu, brak kontroli nad używaniem Internetu, kontynuowanie używania Internetu pomimo negatywnych konsekwencji, jakie to ze sobą niesie, utrata zainteresowania innymi aktywnościami, używanie Internetu celem polepszenia stanu emocjonalnego. Pomimo propozycji badaczy związanych z tym tematem (np. Block, 2008; Grant i in., 2014; Pies, 2009) ogólnie rozumiane uzależnienie od Internetu nie zostało ujęte w ostatecznej wersji klasyfikacji diagnostycznych DSM-5 (APA, 2013) ani ICD-11 (WHO, 2019).

Ciekawych danych dostarczyły badania dotyczące związku między częstotliwością używania Internetu przez dzieci a poziomem ich inteligencji ogólnej oraz regionalną objętością istoty szarej w mózgu (Takeuchi i in., 2018). Objętość istoty szarej w regionach odpowiedzialnych za np. język, uwagę czy pamięć jest istotna z uwagi na jej związki z IQ (Haier, Jung, Yeo, Head, Alkire, 2004). Badania Takeuchiego i in. (2018) miały charakter podłużny, co oznacza, że pomiarów dokonano dwukrotnie - tu akurat w odstępie trzech lat. Większa częstotliwość używania Internetu przez dzieci była związana ze spadkiem inteligencji werbalnej oraz mniejszym wzrostem objętości istoty szarej w regionach mózgu odpowiadających za przetwarzanie języka, uwage, funkcje wykonawcze, emocje oraz w regionach tworzących układ nagrody. Sugeruje to, że nadmierne używanie Internetu, a także uzależnienie, mogą wywoływać negatywne efekty dla funkcjonowania intelektualnego. 
Oprócz inteligencji ogólnej warto zwrócić uwagę na rolę inteligencji emocjonalnej w rozwoju i podtrzymywaniu uzależnienia od Internetu. Według Demetrovicsa, Szeredi i Rózsy (2008) korzystanie z Internetu może stać się strategia radzenia sobie ze stresem i emocjami, szczególnie dla młodych ludzi, którzy nie mogą poradzić sobie ze stresem i mają trudności w adaptowaniu się do różnych sytuacji. Według metaanalizy Ranjbara, Montazerfaraj i Pourmahmoodian (2018) również niższy poziom inteligencji emocjonalnej, która wspiera konstruktywne zarządzanie własnymi emocjami, wydaje się być związany z uzależnieniem od Internetu. Liczba badań na ten temat jest jeszcze zbyt mała, by móc rzetelnie orzekać o znaczeniu tego związku.

Uzależnienie od Internetu może nieść za sobą również szereg zgubnych efektów dla zarządzania nie tylko emocjami, ale także procesami poznawczymi. Nadmierne korzystanie z Internetu wiąże się z byciem pod wpływem wciąż ewoluującego, zmieniającego się systemu informacji, absorbującego uwagę kosztem utrzymywania koncentracji (Firth i in., 2019). W badaniach empirycznych do badania funkcjonowania systemu uwagowego używa się niekiedy Testu sieci uwagowych (Attentional Network Test, ANT; Fan i in., 2002). Konstruując test, autorzy założyli, że system uwagowy można podzielić na trzy niezależne sieci funkcjonalne i anatomiczne: (1) alarmująca (alerting), odpowiedzialną za utrzymanie stanu uważności, czujności; (2) orientująca (orienting), pozwalającą wybrać obszar kierowania uwagi, oraz (3) kontrolę wykonawczą (executive control; która ma za zadanie kontrolować i regulować myśli i działania, a w sytuacji konfliktu poznawczego, gdy konkuruje ze sobą kilka działań, rozwiązywać go, wybierając jedną z aktywności). Według badań Fu, Xu, Zhao i Yu (2018) młodzież z uzależnieniem od Internetu w porównaniu z rówieśnikami, którzy nie mieli takich problemów, przejawiała deficyty w zakresie sieci orientującej, jednak nie w funkcjonowaniu pozostałych sieci. Inne wyniki dotyczące deficytów uwagi w uzależnieniu od Internetu wskazują na obniżone zdolności utrzymywania uwagi u osób z takim problemem. Wskazują także na związki tego zaburzenia z zaburzeniem hiperaktywności z deficytem uwagi (ADHD; np. Tekin, Yetkin, Adıüzel, Akman, 2018; Yen, Ko, Yen, Chang, Cheng, 2009; Yoo i in., 2004). W badaniu Yilmaza, Hergünera, Bilgiça i Işıka (2015) wskazano również na to, że symptomy uzależnienia od Internetu u uczniów szkół średnich są związane właśnie z deficytem uwagi, ale nie z symptomami hiperaktywności. Dane te dostarczają dodatkowych dowodów na istotność sfery poznawczej w rozwoju i podtrzymywaniu nałogu internetowego.

Ogrom informacji oferowanych przez Internet zmienia również naszą pamięć - sposób, w jaki pozyskujemy, magazynujemy, a nawet wartościujemy 
wiedzę (Firth i in., 2019). Badania Zhou i współpracowników (Zhou, Zhou, Zhu, 2016; Zhou, Zhu, Li, Wang, 2014) wykazały deficyty u osób uzależnionych od Internetu w porównaniu z grupa kontrolną w zakresie pamięci roboczej, ale także impulsywności (jako trudności w hamowaniu reakcji). W raportach z tych badań podkreślono, że osoby uzależnione od Internetu nie różnią się pod względem wyżej wymienionych trudności od osób uzależnionymi od alkoholu (Zhou i in., 2014) ani od osób uzależnionych od hazardu, ale uzależnieni od Internetu wykazywali istotnie wyższą impulsywność od uzależnionych od hazardu (Zhou i in., 2016). Ponadto u osób z uzależnieniem od Internetu wykazywane jest wysokie natężenie cech związanych z impulsywnością, mierzonych zarówno kwestionariuszowo (Burnay, Billieux, Blairy, Larøi, 2015; Choi i in., 2014), jak również poprzez zadania poznawcze wymagające hamowania reakcji (Choi i in., 2014; Dong, Devito, Du, Cui, 2012; Dong, Lu, Zhou, Zhao, 2010).

Dodatkowo - intelektualny proces podejmowania decyzji różni się u osób uzależnionych od Internetu w porównaniu z osobami, które nie są uzależnione (np. Dong, Hu, Lin, Lu, 2013; Seok, Lee, Sohn, Sohn, 2015; Sun $i$ in., 2009). Przykładowo w badaniach Donga i in. (2013) osoby z uzależnieniem od Internetu, gdy miały w warunkach laboratoryjnych podejmować decyzje w zadaniach poznawczych, angażowały więcej regionów mózgu odpowiedzialnych za aktywności intelektualne niż osoby bez zaburzeń. Przy podejmowaniu podobnej decyzji po raz drugi nie wykorzystywały w efektywny sposób już posiadanego doświadczenia. Również badania Sun i in. (2009) wskazały na opóźnienia w uczeniu się strategii w zadaniach wymagających podejmowania decyzji u osób z uzależnieniem od Internetu w porównaniu do osób bez tego zaburzenia.

Trudności w zmianie schematów postępowania mają związki ze sztywnością poznawczą, która również okazała się być charakterystyczna dla osób z uzależnieniem od Internetu (np. Dong, Lin, Zhou, Lu, 2014; Zhou i in., 2014). Nie tylko zmiana strategii działania, ale także przełączanie się pomiędzy zadaniami sprawiają takim osobom kłopoty w warunkach laboratoryjnych (np. Dong $\mathrm{i}$ in., 2014; Tekin $\mathrm{i}$ in., 2018), co może przekładać się na gorsze funkcjonowanie poznawcze w niektórych sytuacjach w życiu codziennym.

\section{ZABURZENIE ZWIĄZANE Z GRANIEM W GRY}

Choć ogólnie rozumiane uzależnienie od Internetu nie znalazło swojego miejsca w klasyfikacjach diagnostycznych, zaburzenie związane z grami (w tym 
zapośredniczonymi przez Internet) zostało ujęte w najnowszej, 11 wersji ICD (WHO, 2019). Zaburzenie związane z grami definiuje się jako wzorzec ciągłego lub powtarzalnego grania w gry (cyfrowe lub wideo) online lub offline, które manifestuje się poprzez zmniejszoną kontrolę nad graniem (inicjowanie, częstotliwość, intensywność, czas trwania, zakończenie, kontekst); coraz wyższy priorytet nadawany graniu do tego stopnia, że uzyskuje ono większe znaczenie niż inne zainteresowania życiowe oraz aktywności; kontynuowanie lub eskalowanie grania pomimo negatywnych konsekwencji. Wzorzec zachowania powoduje istotne trudności w obszarach funkcjonowania takich jak: społeczne, edukacyjne, zawodowe lub inne istotne sfery życia. Problemy z graniem mogą występować cały czas lub też epizodycznie i powtarzalnie. Zachowanie to musi manifestować się przez co najmniej 12 miesięcy, jednakże wymagany czas trwania może być krótszy, jeśli występują wszystkie opisane wyżej symptomy i są one silne. Dla porównania, w drugiej wiodącej klasyfikacji zaburzeń psychicznych, DSM-5 (APA, 2013), zaburzenie związane z grami w Internecie znalazło się w sekcji zaburzeń wymagających dalszych badań.

Gry wideo są czasem wykorzystywane w laboratoriach jako narzędzie do badania funkcjonowania intelektualnego (np. Boot, 2015). Wysokie umiejętności w zakresie gry są pozytywnie związane z inteligencją płynną (Kokkinakis, Cowling, Drachen, Wade, 2017), dlatego też niekiedy badacze uważaja interwencje terapeutyczne bazujące na graniu w gry za użyteczne w poprawianiu efektywności funkcjonowania intelektualnego (Shams i in., 2015). Zaangażowanie w granie lub też duże umiejętności grania nie oznaczają jednak, że osoba przejawia zaburzenie kliniczne. Istnieje mało badań porównujących osoby mające problem z graniem (a nie tylko pasjonatów gier czy ekspertów w tym zakresie) z osobami bez zaburzeń pod względem ich IQ. Przykładowo w badaniach Son $i$ in. (2015) nie wykazano w tej domenie różnic między osobami z zaburzeniem związanym z graniem a osobami bez tego zaburzenia.

Częściej w literaturze naukowej można spotkać badania dotyczące inteligencji emocjonalnej i jej podwymiarów wśród osób mających problem z grami. Badania podłużne (tj. prowadzone przez rok) na studentach z Chin wskazały na to, że wyższa inteligencja emocjonalna może chronić przed problematycznym graniem. Jej wpływ nie był jednak bezpośredni, co oznacza, że należy wziąć pod uwagę inne cechy osoby (według wyników tego badania nasilenie symptomów depresyjnych) w orzekaniu o ochronnej roli inteligencji emocjonalnej (Dang, Zhang, Leong, Wu, 2019). W badaniach nad nastolatkami Seo Kang i Chae (2012) wykazały również, że użytkownicy gier wideo przejawiający wysokie ryzyko uzależnienia maja znacząco niższe kompetencje 
emocjonalne oraz inteligencję emocjonalną niż przeciętni gracze. Ponadto nadmierne zaangażowanie w gry może być przejawem tendencji do uciekania przed problemami, czyli nieadaptacyjnej strategii radzenia sobie ze stresem i negatywnymi emocjami (Di Blasi i in., 2019).

W metaanalizie obejmującej badania funkcjonowania mózgu, przeprowadzonej przez Kuss, Pontes i Griffithsa (2018) stwierdzono, że osoby przejawiające zaburzenie związane z grami wideo różnią się od osób bez takiego problemu w swoim funkcjonowaniu poznawczym. Mają one większe trudności w regulacji emocji, gorzej przetwarzają informacje wzrokowe i słuchowe, słabiej funkcjonuje ich pamięć robocza, mają problemy w efektywnym podejmowaniu decyzji, a także trudności w hamowaniu reakcji. Ich neuronalny układ nagrody (odpowiadający na przykład za odczuwanie przyjemności przy korzystaniu z gier) działa w sposób odmienny niż u osób bez zaburzenia. W konkluzji badacze wysunęli wniosek, że trudności te przypominaja problemy osób z uzależnieniami od substancji, co może sugerować wspólne czynniki predysponujące do rozwijania tego typu nałogów oraz zaburzenia związanego z używaniem gier.

U osób z zaburzeniem związanym z graniem w badaniach laboratoryjnych wykazano również zwiększoną reaktywność na wskazówki związane z grami. Przykładowo, gdy przy wykonywaniu zadania poznawczego w tle wyświetlany był obraz związany z gra (Liu i in., 2014) lub gdy zadanie zawierało informacje związane $z$ grami (Zhou, Yuan, Yao, 2012), osoby badane z zaburzeniami związanymi z graniem miały więcej problemów w hamowaniu impulsywnych reakcji.

\section{KOMPULSYWNE ZAKUPY}

We współczesnych czasach zakupy pełnią funkcję nie tylko użytkową ale i społeczna oraz rozrywkowa. W pracach naukowych zwraca się uwagę na hedonistyczny aspekt kupowania (Hirschman, Holbrook, 1982; Rose, Yudham, 2013). Langrehr (1991) zwrócił uwagę na zmianę w kwestii czerpania przyjemności z kupowania. Niegdyś pozytywne emocje wywoływał przedmiot zakupu, natomiast teraz przyjemność przynosi samo doświadczenie kupowania. Pozytywne emocje uległy wzmocnieniu przez rosnąca popularność centrów handlowych oferujących nie tylko możliwość robienia zakupów, ale również korzystania z gastronomii i lokali rozrywkowych (Rose, Yudham, 2013). W kulturach konsumenckich zakupy określane są niekiedy jako „społecznie akceptowane uzależnienie" (Bighiu, Manolica, Roman, 2015). Kupowanie kompulsywne można 
zdefiniować jako wzorzec nagminnego, powtarzającego się robienia zakupów, które stanowią podstawową odpowiedź na negatywne zdarzenia lub uczucia (O’Guinn, Faber 1989; Raudsepp, Parts 2014). Zachowanie to nie ustaje pomimo negatywnych konsekwencji finansowych, społecznych i osobistych (Bighiu i in., 2015; Black, 2007; Ching, Tang, Wu, Yan, 2016; McElroy, Phillips, Keck, 1994). Konsekwencje takiego zachowania obejmują wysokie zadłużenie, negatywne emocje, frustrację, poczucie winy, wstydu i wyobcowania, a także problemy w obszarze osobistym i społecznym, niekiedy nawet rozpad związku i problemy prawne (O’Guinn, Faber, 1989; Lejoyeux, Weinstein, 2010). Użycie terminu „kompulsywne/nałogowe kupowanie” podkreśla podobieństwo tego zachowania do innych zachowań kompulsywnych przez występowanie natrętnych myśli (obsesji) o kupowaniu (Christenson i in., 1994; McElroy $i$ in., 1994) i/lub rytuałów związanych z kupowaniem (Black, 1996; Ogińska-Bulik, 2016).

DeSarbo i Edwards (1996) wyróżnili grupę czynników predysponujących do zaburzenia związanego z kompulsywnym kupowaniem, do której należą negatywne stany afektywne, perfekcjonizm, impulsywność, tendencja do poszukiwania silnych doznań, skłonność do fantazjowania i potrzeba aprobaty społecznej. O’Guinn i Faber (1989) stwierdzili, że żaden pojedynczy czynnik nie wyjaśnia etiologii kompulsywnych zachowań zakupowych i wskazują na szereg czynników, jak poziom pobudzenia (nuda lub podniecenie), poziom doświadczanego stresu i lęku, niska samoocena, skłonność do poszukiwania doznań oraz zewnętrzne bodźce ze środowiska (np. media i reklamy). Do tej pory zaburzenie związane z kompulsywnym kupowaniem nie zostało jednak zaklasyfikowane w DSM-5 (APA, 2013) ani ICD-11 (WHO, 2019).

Zebrane dotychczas dane sugerują, że osoby dotknięte zaburzeniem kompulsywnego kupowania doświadczaja problemów związanych z funkcjonowaniem poznawczym. Osoby te mogą wykazywać znaczne upośledzenie w hamowaniu reakcji i w ocenie ryzyka podczas podejmowania decyzji. Przejawiają także deficyty w pamięci roboczej i osiągają gorsze wyniki w zakresie miar funkcji wykonawczych (Derbyshire, Chamberlain, Odlaug, Grant, 2014). Jednocześnie kompulsywni kupujący osiagają wyższe wyniki w testach percepcji wzrokowej Skali inteligencji Wechslera (Black, Shaw, McCormick, Bayless, Allen, 2012). Nierzadko za kompulsywnymi zachowaniami zakupowymi idzie tendencja do pochopnego działania w trudnej sytuacji, jako komponent impulsywności, co odkrył Rochat wraz z zespołem (Rochat, Beni, Billieux, Annoni, Van der Linden, 2011) podczas badania pacjentów z urazowym uszkodzeniem mózgu (TBI). Zarówno tendencja do pochopnych 
decyzji i działań, jak i kompulsywnego kupowania znacznie wzrosła po doświadczeniu takiego urazu.

W badaniu Parka i Dhandry (2017) odkryto natomiast negatywny związek uważności ze skłonnością do kupowania pod wpływem impulsu. Można rozumieć przez to, że osoby o niskiej uważności przejawiają większą tendencję do kompulsywnego kupowania. Jednocześnie wykazano, że inteligencja emocjonalna, a szczególnie zdolność do oceny własnych emocji, pośredniczy między uważnością a zaburzeniem impulsywnego kupowania. Wysoka uważność prowadzi do pogłębionej samoświadomości i jest związana z wyższą inteligencją emocjonalna; inteligencja emocjonalna natomiast negatywnie koreluje z impulsywnym nabywaniem, a jej wysoki poziom zmniejsza ryzyko impulsywnych zachowań. Istnieją spójne dowody wskazujące na znaczenie inteligencji emocjonalnej w kompulsywnym kupowaniu. Rose i Segrist (2012) wskazali na trudność w identyfikacji przeżywanych uczuć u osób przejawiających zaburzenia kontroli impulsów i kupowania kompulsywnego. Jednocześnie w badaniu Lin i Chuanga (2005) wykazano, że nastolatki o wysokiej inteligencji emocjonalnej dużo rzadziej wykazują impulsywne zachowania niż nastolatki o niskim jej wskaźniku. Peter i Krishnakumar (2010) podkreślili również, że zdolność rozumienia emocji może wpływać na jakość decyzji konsumenckich.

Trudności poznawcze $\mathrm{w}$ zakresie impulsywności widoczne są $\mathrm{w}$ niektórych wyjaśnieniach niekontrolowanych zakupów, na przykład w opisie zaproponowanym przez Baumeistera (2002). Według niego jednostka w wyniku doświadczanego stresu jest podatna na rozluźnienie samokontroli, a w efekcie działa impulsywnie. Inne koncepcje opisuja jednak kupowanie impulsywne i kompulsywne jako rozłączne zjawiska, co wynika z założenia, że zachowania impulsywne i kompulsywne, choć podobne, nie są tożsame. Zakup impulsywny ma charakter nagły, spontaniczny i dokonywany jest pod wpływem zewnętrznego bodźca (np. widoku atrakcyjnego towaru w sklepie). W przypadku zakupów kompulsywnych istotny jest czynnik wewnętrzny, pod postacia negatywnych uczuć (głównie lęku lub złego samopoczucia) i chęci poradzenia sobie z nimi. Zakupy więc stanowią sposób na redukcję napięcia i radzenie sobie, co nie występuje w przypadku zakupów impulsywnych. Ponadto nabywcy kompulsywni poświęcają więcej czasu na zakupy, częściej też wybierają niepotrzebne im produkty. Choć osoby kompulsywne moga dokonać zakupu pod wpływem impulsu, to wciąż kierują się oni wewnętrzną motywacją redukcji negatywnych stanów emocjonalnych. W efekcie to kupowanie kompulsywne, a nie impulsywne prowadzi do uzależnienia (Bighiu i in., 2015; Ogińska-Bulik, 
2016), choć, jak zaznaczają Grant i Potenza (2006), obydwa rodzaje zachowań - impulsywne, jak i kompulsywne - nie muszą się wykluczać.

Badacze jednoznacznie wskazują na negatywne stany afektywne wśród kompulsywnych kupujących. Osoby te są skłonne dodawać koncepcje emocjonalne do przedmiotów, które zakupili, a zakupy są dla nich opartą na unikaniu strategia radzenia sobie ze stresem i negatywnymi emocjami. Krótkotrwałe złagodzenie stresu i poprawa samopoczucia mają właściwości silnie wzmacniające, co prowadzi do rozwoju zaburzenia kompulsywnego kupowania w chwili pojawienia się negatywnego afektu (Ching i in., 2016). Podczas gdy zakupy mogą pełnić rolę w mechanizmach ucieczki przed uczuciami lęku i depresji (DeSarbo, Edwards, 1996; Rick, Pereira, Burson, 2014), mogą także być powodem lęku i depresji na przykład w związku z negatywnymi konsekwencjami wynikłymi z nadmiernych zakupów (Roberts, 1998). Niezależnie od kierunku, każde z podejść potwierdza dodatni związek zakupoholizmu z objawami lęku i depresji oraz negatywny związek z samooceną (Andreassen $i$ in., 2015).

Inne trudności w funkcjonowaniu poznawczym kompulsywnych kupujacych w porównaniu ze zwykłymi klientami objawiają się na przykład w tym, że kompulsywni nabywcy kupują bez długotrwałego procesu decyzyjnego (Bighiu i in., 2015), wykazują większą skłonność do nadmiernych, niekontrolowanych wydatków, są mniej świadomi swoich ograniczeń budżetowych podczas dokonywanych zakupów oraz rzadziej dostrzegają utratę wydanych środków i poszukują dodatkowych informacji na temat zamawianych produktów (Lo, Harvey, 2011), a swoje potrzeby zaspokajają w samym akcie zakupów, ciesząc się procesem kupna, po czym tracą zainteresowanie użyciem i wykorzystaniem nowych rzeczy (np. nie wyjmuja zakupionych ubrań z torby na zakupy; Raudsepp, Parts, 2014; Rose, Yudham, 2013).

Specyficzną formą zaburzenia kompulsywnego kupowania, z jaką mamy do czynienia współcześnie, są zakupy internetowe. Z badań Donthu i Garcii (1999) wynika, że konsumenci wybierający produkty online są bardziej impulsywni w porównaniu z osobami, które korzystają z zakupów offline. Jest to spójne z wynikami analizy przeprowadzonej przez firmę ADTECH (zajmująca się obsługą reklam), według których czterech na pięciu użytkowników Internetu to klienci impulsywni (Bighiu i in., 2015). Środowisko sieci online sprzyja utracie samokontroli, co w rezultacie może doprowadzić do zużycia zasobów w zakresie samoregulacji w związku z zakupami online (Rose, Yudham, 2013; Sun, Wu, 2011). 


\section{PROBLEMY W KONTROLOWANIU ZACHOWAŃ SEKSUALNYCH}

Już od lat ' $80 \mathrm{XX}$ wieku, na potrzeby stawiania diagnoz psychiatrycznych, podejmowano próby klasyfikacji problemów w kontrolowaniu zachowań seksualnych (np. American Psychiatric Association [APA], 1987). Proponowane wówczas definicje skupiały się jednak na subiektywnie doświadczanym niepokoju związanym z zachowaniem seksualnym (Kor, Fogel, Reid, Potenza, 2013). Utrudniało to stawianie jednoznacznych, obiektywnych diagnoz. Odpowiedzia na ten problem stały się dyskusje nad ujęciem patologicznej hiperseksualności w DSM-5 (bypersexuality disorder, HD; np. Kor i in., 2013; Montgomery-Graham, 2017; Reid i in., 2012; Reid, Kafka, 2014; ostatecznie jednostka nie znalazła się w tej klasyfikacji diagnostycznej) oraz podobnie definiowanego zaburzenia związanego z kompulsywnymi zachowaniami seksualnymi w ICD11 (compulsive sexual behavior disorder, CSBD; np. Kowalewska, Kraus, Lew-Starowicz, Gustavsson, Gola, 2019; Kraus i in., 2018; Stark, Klucken, Potenza, Brand, Strahler, 2018; zaburzenie to ostatecznie znalazło się w najnowszej wersji klasyfikacji ICD; WHO, 2019).

Zaburzenie związane z kompulsywnymi zachowaniami seksualnymi jest ujmowane jako zaburzenie kontroli impulsów (typ zaburzeń spokrewniony z nałogami), dla którego charakterystyczny jest wzorzec powtarzalnych niepowodzeń w kontrolowaniu własnych zachowań, myśli i/lub pragnień seksualnych. Aby otrzymać pozytywną diagnozę zaburzenia, osoba musi przez ostatnie 6 miesięcy lub dłużej przejawiać symptomy takie jak: (1) powtarzalne zaangażowanie w aktywności seksualne, które stają się centralną osią życia osoby, do tego stopnia, że zaniedbuje ona zdrowie, siebie samą lub swoje zainteresowania, aktywności czy zobowiązania; (2) podejmowanie licznych, zakończonych niepowodzeniem wysiłków, aby zredukować liczbę nawracających zachowań seksualnych i (3) kontynuowanie tych zachowań pomimo czerpania z nich małej ilości satysfakcji; (4) zachowania te powoduja znaczące cierpienie lub trudności w funkcjonowaniu w sferach osobistej, rodzinnej, edukacyjnej, zawodowej lub innych ważnych obszarach życia. Wspomniane cierpienie/trudności nie mogą być ponadto związane wyłącznie z subiektywną, negatywną ocena moralną własnych impulsów seksualnych, potrzeb czy zachowań (Kraus i in., 2018; WHO, 2019).

Badania na osobach poszukujących terapii (Reid i in., 2012) wskazują na to, że kompulsywne zachowania seksualne manifestują się najczęściej poprzez nadużywanie pornografii (81\%), masturbacji (78\%), ryzykowne i/lub anonimowe stosunki seksualne (44\%) lub częste korzystanie z płatnych usług seksualnych (17\%). W przypadku tego zaburzenia właśnie te zachowania stano- 
wią główne powody poszukiwania profesjonalnej pomocy. Należy również zwrócić uwagę na uzależniający potencjał pornografii (Wordecha i in., 2018) oraz występowanie zjawiska głodu nałogowego w przypadku problematycznego jej używania (Antons, Brand, 2018; Brand, Snagowski i in., 2016; Gola i in., 2017; Kraus, Rosenberg, 2014; Laier, Pawlikowski, Pekal, Schulte, Brand, 2013; Snagowski, Brand, 2015; Weinstein, Zolek, Babkin, Cohen, Lejoyeux, 2015). Przywoływane dane dostarczają informacji o tym, że być może słuszne jest rozumienie CSBD jako jednego z rodzajów uzależnień behawioralnych (np. Gola, Potenza, 2016; Kowalewska i in., 2018; Kraus i in., 2016; Starcevic, Khazaal, 2017). Badania neuroobrazowe na osobach przejawiających CSBD wskazały na zmiany w aktywności ich struktur mózgowych przypominające zmiany u osób z uzależnieniami od substancji, hazardu czy gier (Kowalewska $\mathrm{i}$ in., 2018). Zmiany w funkcjonowaniu dotyczyły obszarów odpowiadających za sensytyzację (uwrażliwianie na bodźce) i habituację (zmniejszoną wrażliwość na bodźce, potocznie rozumiane jako przyzwyczajanie się do bodźców), zmniejszenie kontroli nad impulsami oraz przetwarzanie w układzie nagrody.

Porównania osób z problemami w kontrolowaniu zachowań seksualnych z osobami bez takich problemów biorące pod uwagę poziom IQ są nieczęsto przeprowadzane, a dostępne obecnie wyniki są niespójne. W badaniach Reida, Garos, Carpentera i Colemana (2011) mężczyźni z symptomami hiperseksualności wykazywali nieco niższe wyniki IQ niż grupa kontrolna bez zaburzeń. W badaniach Engela i in. (2019) analogiczne grupy badanych mężczyzn natomiast nie różniły się pod tym względem. Obecne badania na ten temat są jednak w fazie wstępnej i w obecnym stanie nie pozwalają na wyciaganie daleko idących wniosków na temat związku pomiędzy problemami w kontrolowaniu własnych zachowań seksualnych a poziomem inteligencji.

Podobnie jak w przypadku badań nad inteligencją ogólną liczba raportów na temat inteligencji emocjonalnej czy funkcjonowania emocjonalnego wśród pacjentów z CSBD jest niewielka. W badaniach na osobach uzależnionych od substancji trudności w regulacji emocji były związane z hiperseksualnościa (Hashemi, Shalchi, Yaghoubi, 2018). Podobne wyniki uzyskano na wysoko aktywnych seksualnie homo- i biseksualnych mężczyznach (Pachankis, Rendina, Ventuneac, Grov, Parsons, 2014). W innych badaniach wysokie nasilenie kompulsywności seksualnej u studentów związane było z niższą akceptacją własnych emocji, problemami w zaangażowaniu w zachowania nakierowane na określony cel w sytuacji obniżonego nastroju oraz nieadaptacyjną regulacja nastroju w czasie gdy osoba odczuwa negatywne emocje (Cashwell, Giordano, King, Lankford, Henson, 2017). 
Większa liczba badań na temat funkcjonowania poznawczego osób z problemami w kontrolowaniu zachowań seksualnych dotyczy funkcji wykonawczych. Według raportu Reida (Reid, Karim, McCrory, Carpenter, 2010) osoby z objawami hiperseksualności w badaniach wykazują względem osób, które nie maja takiego problemu, różnice w zakresie funkcji wykonawczych takich jak przełączanie się pomiędzy zadaniami, kontrolowanie emocji, inicjatywa, planowanie i organizowanie. Badania wskazuja, że kluczowym aspektem poznawczym (związanym z funkcjami wykonawczymi) w przypadku problematycznych zachowań seksualnych są jednak trudności w regulacji i kontrolowaniu impulsów, motywacji i pragnień seksualnych (Barth, Kinder, 1987; Chamberlain, Grant, 2019; Kalichman i in., 1994; Kaplan, 2013; Mulhauser i in., 2014; Reid, Garos, Carpenter, Coleman, 2011; Schiebener, Laier, Brand, 2015). Przejawia się to poprzez nieprzemyślane i ryzykowne zachowania seksualne przy poczuciu, że myśli seksualne wpływają na codzienne życie, relacje i aktywności (Kalichman i in., 1994; Reid, Garos, Carpenter, 2011).

Główną motywacją do realizacji impulsów seksualnych jest osobista potrzeba doświadczenia przyjemności (Giugliano, 2008, 2009). Utrata kontroli nad tymi impulsami może doprowadzić do podejmowania pochopnych działań nakierowanych na natychmiastowa gratyfikację. Dysfunkcja mechanizmów kontroli oraz funkcji wykonawczych pojawia się w szczególności w sytuacjach konfrontacji ze wskazówkami z otoczenia związanymi z problemowym zachowaniem, na przykład pornografią (Allen, Kannis-Dymand, Katsikitis, 2017; Antons, Brand, 2018; Schiebener i in., 2015, Snagowski, Brand, 2015). Mechanizmy odpowiadające za to, by nie reagować emocjami oraz myślami o problematycznym zachowaniu w odpowiedzi na tego typu wskazówki, sa słabsze u osób z tendencjami do nałogowego korzystania (Laier, Pawlikowski, Brand, 2014; Laier, Pekal, Brand, 2014). Ciekawych danych na ten temat dostarczyło badanie Schiebenera i in. (2015) dotyczące kontroli wykonawczej nad działaniami. Badani mężczyźni mieli za zadanie zaklasyfikować wyświetlane na ekranie zdjęcia według podanych kategorii. Pierwszy zestaw zawierał zwyczajne wizerunki osób, drugi natomiast składał się ze zdjęć pornograficznych. Osoby, które wykazywały wyższe tendencje do nałogowego korzystania $z$ internetowych materiałów seksualnych (np. stron pornograficznych), radziły sobie z tym zadaniem gorzej niż osoby z niższymi tendencjami tego rodzaju, nie klasyfikując w ogóle obrazów pornograficznych lub też zatrzymywały się nad tymi obrazkami. Sugerowało to tendencje do unikania lub też dążenia do materiału wywołującego reakcje emocjonalne, co jest zgodne z motywacyjnymi modelami uzależnienia. 
Inne wyniki badań dotyczących podejmowania decyzji, a także elastyczności poznawczej u osób z kompulsywnymi zachowaniami seksualnymi, dotyczyły zachowań przed oraz tuż po obejrzeniu filmu erotycznego. Osoby te były porównane z uczestnikami badania, którzy nie mieli problemu z kompulsywnymi zachowaniami seksualnymi (grupa kontrolna). Obie badane grupy podobnie radziły sobie z zadaniami poznawczymi dotyczącymi badanych aspektów ich funkcjonowania przed obejrzeniem filmu. Po obejrzeniu filmu grupa osób z kompulsywnymi zachowaniami seksualnymi wykazała się jednak większą impulsywnością w podejmowaniu decyzji oraz słabszą elastycznością poznawczą niż grupa kontrolna. Obecność materiałów pornograficznych mogła wywoływać u osób z CSBD powracające myśli związane z erotyka, zmniejszające efektywność wykonywanych zadań. Dane uzyskane w badaniu wskazały na to, że osoby z kompulsywnymi zachowaniami seksualnymi pod wpływem wskazówek z otoczenia związanych z seksem mają trudności z hamowaniem reakcji oraz gorzej adaptują swoje zachowanie do zmieniających się warunków. W realnym życiu może to mieć odzwierciedlenie w angażowaniu się przez te osoby w ryzykowne zachowania oraz przejawiać się trudnościami z modyfikacją własnych zachowań seksualnych (Messina, Fuentes, Tavares, Abdo, Scanavino, 2017).

\section{PODSUMOWANIE}

Funkcjonowanie poznawcze i jego liczne podwymiary, w szczególności niższy poziom inteligencji emocjonalnej oraz deficyty w zakresie funkcji wykonawczych, choć jedynie od niedawna badane w odniesieniu do uzależnień behawioralnych, wydają się istotnymi komponentami trudności osób dotkniętych nałogami. Zdolności do efektywnego zarządzania własnym zachowaniem, podejmowania decyzji i korzystania z dotychczasowego doświadczenia maja znaczący wpływ na opieranie się zachowaniom nałogowym, a także korzystanie z oferowanej pomocy terapeutycznej i podtrzymywanie efektów leczenia. Chociaż rzetelne wyjaśnienie podłoża uzyskiwanych wyników wymaga dalszych badań, jednym z głównych mechanizmów-kandydatów do wyjaśnienia związku pomiędzy kontrolą poznawczą a zachowaniami nałogowymi jest to, że niższe zdolności poznawcze, a w szczególności obniżona kontrola poznawcza, prowadzą do większej częstotliwości zachowań gratyfikujących, zwłaszcza tych utrwalonych i nawykowych (jak zachowania nałogowe w uzależnieniach behawioralnych), również wtedy, gdy wiążą się one z ryzykiem (finansowym, jak w przypadku gier hazardowych, czy zdrowotnym, jak w przypadku problemów 
z kontrolą zachowań seksualnych) i negatywnymi konsekwencjami (Grant, Chamberlain, 2014). Obniżony poziom zdolności poznawczych związanych z funkcjonowaniem emocjonalnym i społecznym, jak inteligencja emocjonalna, może zaś prowadzić do (1) wyższego ryzyka rozwoju zachowań nałogowych ze względu na nieumiejętność poszukiwania wsparcia społecznego, lub (2) stosowania zachowań nałogowych jako sposobów radzenia sobie ze stresem i negatywnymi emocjami w obliczu nieumiejętności posługiwania się innymi, adaptacyjnymi strategiami (Kun, Demetrovics, 2010).

W świetle wyników badań epidemiologicznych omówionych we Wprowadzeniu (np. Badora i in., 2015; Moskalewicz i in., 2019) uzależnienia behawioralne stają się coraz bardziej popularnym zjawiskiem wśród Polaków. Coraz szerszy dostęp do technologii, a także tendencje konsumpcjonistyczne, ułatwiają rozwijanie symptomów tych zaburzeń, a niekiedy je legitymizuja (jak w przypadku zakupów kompulsywnych; Bighiu i in., 2015). Dlatego też odnajdywanie czynników ryzyka uzależnień na poziomie indywidualnym jest bardzo istotnym zadaniem dla nauk medycznych i psychologicznych - na takie czynniki można bowiem wpływać w procesie terapii. Aby to umożliwić, przyszłe badania w obszarze funkcjonowania poznawczego osób z uzależnieniami behawioralnymi powinny skupiać się na jak największych próbach klinicznych (to jest osób posiadających diagnozę danego zaburzenia) w porównaniu z grupami kontrolnymi osób bez rozpoznania tego typu zaburzeń, a także z grupami osób uzależnionych od substancji. Ten ostatni rodzaj porównań może przyczynić się do lepszego zrozumienia natury uzależnień behawioralnych i adekwatnego ich traktowania w klasyfikacjach diagnostycznych - innymi słowy, czy zasadne jest traktowanie tych zaburzeń jako typowych uzależnień, czy też bardziej odpowiednie jest mówienie o nich jako na przykład zaburzeniach kontroli impulsów.

Ponadto na podstawie wyników badań może okazać się, że konieczne jest wydzielenie jakościowo rozłącznych podtypów uzależnień behawioralnych. Przyczyni się to do lepszego rozumienia osób poszukujących profesjonalnej pomocy oraz projektowania takich oddziaływań, które możliwie najlepiej odpowiedzą na ich potrzeby oraz umożliwią im przezwyciężenie trudności. Niebagatelną rolę mogą tutaj odegrać różnice między osobami bez nałogów behawioralnych a osobami z nałogami w charakterystyce ich trudności w funkcjonowaniu poznawczym, na przykład poziomu inteligencji ogólnej i emocjonalnej, sposobów regulowania emocji, impulsywności. Wyróżnienie dominujących trudności poznawczych u danej jednostki i nakierowanie terapii na ich zmniejszenie ma szansę przynieść lepsze efekty niż proponowanie niezróżni- 
cowanych oddziaływań, które odnoszą się do zbyt uogólnionego rozumienia danego uzależnienia.

\section{BIBLIOGRAFIA}

Allen, A., Kannis-Dymand, L., Katsikitis, M. (2017). Problematic Internet pornography use: The role of craving, desire thinking, and metacognition. Addictive Behaviors, 70, 65-71. https://doi.org/10.1016/j.addbeh.2017.02.001

American Psychiatric Association. (1987). Diagnostic and statistical manual of mental disorders (3rd ed., Text Revision) (DSM-III-TR). Waszyngton: American Psychiatric Association.

American Psychiatric Association. (2013). Diagnostic and statistical manual of mental disorders (5th ed.). Waszyngton: American Psychiatric Association. https://doi. org/10.1176/appi.books.9780890425596

Andreassen, C. S., Griffiths, M. D., Gjertsen, S. R., Krossbakken, E., Kvam, S., Pallesen, S. (2013). The relationships between behavioral addictions and the five-factor model of personality. Journal of Behavioral Addictions, 2(2), 90-99. https:// doi.org/10.1556/JBA.2.2013.003

Andreassen, C. S., Griffiths, M. D., Pallesen, S., Bilder, R. M., Torsheim, T., Aboujaoude, E. (2015). The Bergen Shopping Addiction Scale: Reliability and validity of a brief screening test. Frontiers in Psychology, 6, 1374. https://doi.org/10.3389/ fpsyg.2015.01374

Antons, S., Brand, M. (2018). Trait and state impulsivity in males with tendency towards Internet-pornography-use disorder. Addictive Behaviors, 79, 171-177. https:// doi.org/10.1016/j.addbeh.2017.12.029

Austin, E. J., Saklofske, D. H., Egan, V. (2005). Personality, well-being and health correlates of trait emotional intelligence. Personality and Individual Differences, 38(3), 547-558. https://doi.org/10.1016/j.paid.2004.05.009

Baddeley, A. (1992). Working memory. Science, 255(5044), 556-559. https://doi. org/10.1126/science.1736359

Baddeley, A. D., Logie, R. H. (1999). Working memory: The multiple-component model. W: A. Miyake, P. Shah (red.), Models of working memory (s. 28-61). Nowy Jork: Cambridge University Press. https://doi.org/10.1017/CBO9781139174909.005

Badora, B., Gwiazda, M., Herrmann, M., Kalka, J., Moskalewicz, J. (2015). Oszacowanie rozpowszechnienia wybranych uzależnień behawioralnych oraz analiza korelacji pomiedzy występowaniem uzależnień behawioralnych a używaniem substancji psychoaktywnych. Cześć I: Rozpowszechnienie wybranych uzależnień behawioralnych i ich zwiazek z. u̇ywaniem substancï 
psychoaktywnych. Warszawa: Ministerstwo Zdrowia, Krajowe Biuro ds. Przeciwdziałania Narkomanii, Centrum Badania Opinii Społecznej.

Banca, P., Morris, L. S., Mitchell, S., Harrison, N. A., Potenza, M. N., Voon, V. (2016). Novelty, conditioning and attentional bias to sexual rewards. Journal of Psychiatric Research, 72, 91-101. https://doi.org/10.1016/j.jpsychires.2015.10.017

Barth, R. J., Kinder, B. N. (1987). The mislabeling of sexual impulsivity. Journal of Sex \& Marital Therapy, 13(1), 15-23. https://doi.org/10.1080/00926238708403875

Baumeister, R. F. (2002). Yielding to temptation: Self-control failure, impulsive purchasing, and consumer behavior. Journal of Consumer Research, 28(4), 670-676. https://doi.org/10.1086/338209

Bechara, A., Martin, E. M. (2004). Impaired decision making related to working memory deficits in individuals with substance addictions. Neuropsychology, 18(1), 152-162. https://doi.org/10.1037/0894-4105.18.1.152

Bighiu, G., Manolica, A., Roman, C. T. (2015). Compulsive buying behavior on the Internet. Procedia Economics and Finance, 20, 72-79. https://doi.org/10.1016/S22125671(15)00049-0

Billieux, J., Schimmenti, A., Khazaal, Y., Maurage, P., Heeren, A. (2015). Are we overpathologizing everyday life? A tenable blueprint for behavioral addiction research. Journal of Behavioral Addictions, 4(3), 119-123. https://doi. org/10.1556/2006.4.2015.009

Binet, A., Simon, T. (1916). The development of intelligence in children: The Binet-Simon Scale. Baltimore: Williams \& Wilkins Co.

Black, D. W. (2007). A review of compulsive buying disorder. World Psychiatry, 6(1), 14-18.

Black, D. W. (1996). Compulsive buying: A review. The Journal of Clinical Psychiatry, 57(Suppl 8), 50-55.

Black, D. W., Shaw, M., McCormick, B., Bayless, J. D., Allen, J. (2012). Neuropsychological performance, impulsivity, ADHD symptoms, and novelty seeking in compulsive buying disorder. Psychiatry Research, 200(2-3), 581-587. https://doi. org/10.1016/j.psychres.2012.06.003

Blaszczynski, A., Nower, L. (2002). A pathways model of problem and pathological gambling. Addiction, 97(5), 487-499. https://doi.org/10.1046/j.13600443.2002.00015.x

Block, J. J. (2008). Issues for DSM-V: Internet addiction. American Journal of Psychiatry, 165(3), 306-307. https://doi.org/10.1176/appi.ajp.2007.07101556

Boot, W. R. (2015). Video games as tools to achieve insight into cognitive processes. Frontiers in Psychology, 6, 3. https://doi.org/10.3389/fpsyg.2015.00003 
Brand, M., Snagowski, J., Laier, C., Maderwald, S. (2016). Ventral striatum activity when watching preferred pornographic pictures is correlated with symptoms of Internet pornography addiction. Neuroimage, 129, 224-232. https://doi. org/10.1016/j.neuroimage.2016.01.033

Brand, M., Young, K. S., Laier, C. (2014). Prefrontal control and Internet addiction: A theoretical model and review of neuropsychological and neuroimaging findings. Frontiers in Human Neuroscience, 8, 375. https://doi.org/10.3389/fnhum.2014.00375

Brand, M., Young, K. S., Laier, C., Wölfling, K., Potenza, M. N. (2016). Integrating psychological and neurobiological considerations regarding the development and maintenance of specific Internet-use disorders: An Interaction of Person-Affect-Cognition-Execution (I-PACE) model. Neuroscience \& Biobehavioral Reviews, 71, 252-266. https://doi.org/10.1016/j.neubiorev.2016.08.033

Breyer, J., Botzet, A., Winters, K., Stinchfield, R. D., August, G., Realmuto, G. (2009). Young adult gambling behaviors and their relationship with the persistence of ADHD. Journal of Gambling Studies, 25(2), 227-238. https://doi.org/10.1007/ s10899-009-9126-z

Broussard, J., Wulfert, E. (2019). Debiasing of gambling beliefs and behaviors using a digital gambling accelerator. Psychology of Addictive Behaviors, 33(3), 337-348. https://doi.org/10.1037/adb0000463

Burnay, J., Billieux, J., Blairy, S., Larøi, F. (2015). Which psychological factors influence Internet addiction? Evidence through an integrative model. Computers in Human Behavior, 43, 28-34. https://doi.org/10.1016/j.chb.2014.10.039

Cañas, J., Quesada, J., Antolí, A., Fajardo, I. (2003). Cognitive flexibility and adaptability to environmental changes in dynamic complex problem-solving tasks. Ergonomics, 46(5), 482-501. https:/ / doi.org/10.1080/0014013031000061640

Cardinal, R. N., Pennicott, D. R., Lakmali, C., Robbins, T. W., Everitt, B. J. (2001). Impulsive choice induced in rats by lesions of the nucleus accumbens core. Science, 292(5526), 2499-2501. https://doi.org/10.1126/science.1060818

Carter, B. L., Tiffany, S. T. (1999). Meta-analysis of cue-reactivity in addiction research. Addiction, 94(3), 327-340. https://doi.org/10.1046/j.13600443.1999.9433273.x

Cashwell, C. S., Giordano, A. L., King, K., Lankford, C., Henson, R. K. (2017). Emotion regulation and sex addiction among college students. International Journal of Mental Health and Addiction, 15(1), 16-27. https://doi.org/10.1007/s11469-0169646-6

Cattell, R. B. (1972). Real base, true zero factor analysis. Fort Worth: Texas Christian University Press. 
Chamberlain, S. R., Grant, J. E. (2019). Relationship between quality of life in young adults and impulsivity/compulsivity. Psychiatry Research, 271, 253-258. https://doi. org/10.1016/j.psychres.2018.11.059

Chamberlain, S. R., Stochl, J., Redden, S. A., Odlaug, B. L., Grant, J. E. (2017). Latent class analysis of gambling subtypes and impulsive/compulsive associations: Time to rethink diagnostic boundaries for gambling disorder? Addictive Behaviors, 72, 79-85. https://doi.org/10.1016/j.addbeh.2017.03.020

Charlton, J. P. (2002). A factor-analytic investigation of computer 'addiction' and engagement. British Journal of Psychology, 93(3), 329-344. https://doi. org/10.1348/000712602760146242

Ching, T. H., Tang, C. S., Wu, A., Yan, E. (2016). Gender differences in pathways to compulsive buying in Chinese college students in Hong Kong and Macau. Journal of Behavioral Addictions, 5(2), 342-350. https://doi.org/10.1556/2006.5.2016.025

Choi, J. S., Park, S. M., Roh, M. S., Lee, J. Y., Park, C. B., Hwang, J. Y., Jung, H. Y. (2014). Dysfunctional inhibitory control and impulsivity in Internet addiction. Psychiatry Research, 215(2), 424-428. https://doi.org/10.1016/j.psychres.2013.12.001

Christenson, G., Faber, R., de Zwaan, M., Raymond, N., Specker, S., Ekern, M., ..., Mitchel, J. E. (1994). Compulsive buying: Descriptive characteristics and psychiatric comorbidity. The Journal of Clinical Psychiatry, 55(1), 5-11.

Chuderski, A. (2019). Even a single trivial binding of information is critical for fluid intelligence. Intelligence, 77, 101396. https://doi.org/10.1016/j.intell.2019.101396

Chuderski, A., Nęcka, E. (2010). Intelligence and cognitive control. W: A. Gruszka, G. Matthews, B. Szymura (red.), Handbook of individual differences in cognition (s. 263-282). Nowy Jork: Springer. https://doi.org/10.1007/978-1-4419-1210-7_16

Clark, L. (2010). Decision-making during gambling: An integration of cognitive and psychobiological approaches. Philosphical Transactions of the Royal Society B: Biological Sciences, 365(1538), 319-330. https://doi.org/10.1098/rstb.2009.0147

Cotruş, A., Stanciu, C., Bulborea, A. A. (2012). EQ vs. IQ which is most important in the success or failure of a student? Procedia-Social and Behavioral Sciences, 46, 5211-5213. https://doi.org/10.1016/j.sbspro.2012.06.411

Czerniawska, E. (2006). Metapoznanie a inteligencja - przegląd poglądów teoretycznych i wyników badań. Przeglad Psychologiczny, 49(2), 119-139.

Dang, D. L., Zhang, M. X., Leong, K. K. H., Wu, A. (2019). The predictive value of emotional intelligence for Internet gaming disorder: A 1-year longitudinal study. International Journal of Environmental Research and Public Health, 16(15), 2762. https:/ / doi.org/10.3390/ijerph16152762 
Demetrovics, Z., Griffiths, M. D. (2012). Behavioral addictions: Past, present and future. Journal of Behavioral Addictions, 1(1), 1-2. https://doi.org/10.1556/ JBA.1.2012.1.0.

Demetrovics, Z., Szeredi, B., Rózsa, S. (2008). The three-factor model of Internet addiction: The development of the Problematic Internet Use Questionnaire. Behavior Research Methods, 40(2), 563-574. https://doi.org/10.3758/BRM.40.2.563

Derbyshire, K. L., Chamberlain, S. R., Odlaug, B. L., Grant, J. E. (2014). Neurocognitive functioning in compulsive buying disorder. Annals of Clinical Psychiatry, 26(1), 57-63.

DeSarbo, W., Edwards, E. (1996). Typologies of compulsive buying behavior: A constrained clusterwise regression approach. Journal of Consumer Psychology, 5(3), 231262. https://doi.org/10.1207/s15327663jcp0503_02

Di Blasi, M., Giardina, A., Giordano, C., Coco, G. L., Tosto, C., Billieux, J., Schimmenti, A. (2019). Problematic video game use as an emotional coping strategy: Evidence from a sample of MMORPG gamers. Journal of Behavioral Addictions, 8(1), 25-34. https://doi.org/10.1556/2006.8.2019.02

Diamond, A. (2013). Executive functions. Annual Review of Psychology, 64, 135-168. https://doi.org/10.1146/annurev-psych-113011-143750

Dong, G., Devito, E. E., Du, X., Cui, Z. (2012). Impaired inhibitory control in 'Internet addiction disorder': A functional magnetic resonance imaging study. Psychiatry Research: Neuroimaging, 203(2-3), 153-158. https://doi.org/10.1016/j.pscychresns.2012.02.001

Dong, G., Hu, Y., Lin, X., Lu, Q. (2013). What makes Internet addicts continue playing online even when faced by severe negative consequences? Possible explanations from an fMRI study. Biological Psychology, 94(2), 282-289. https://doi. org/10.1016/j.biopsycho.2013.07.009

Dong, G., Lin, X., Zhou, H., Lu, Q. (2014). Cognitive flexibility in Internet addicts: fMRI evidence from difficult-to-easy and easy-to-difficult switching situations. Addictive Behaviors, 39(3), 677-683. https://doi.org/10.1016/j.addbeh.2013.11.028

Dong, G., Lu, Q., Zhou, H., Zhao, X. (2010). Impulse inhibition in people with Internet addiction disorder: Electrophysiological evidence from a Go/ NoGo study. Neuroscience Letters, 485(2), 138-142. https://doi.org/10.1016/j. neulet.2010.09.002

Donthu, N., Garcia, A. (1999). The Internet shopper. Journal of Advertising Research, 39, 52-58.

Eagle, D. M., Bari, A., Robbins, T. W. (2008). The neuropsychopharmacology of action inhibition: Cross-species translation of the stop-signal and go/no-go tasks. Psychopharmacology, 199(3), 439-456. https://doi.org/10.1007/s00213-008-1127-6 
Emanuel, E. J., Gudbranson, E. (2018). Importance of intelligence and emotional intelligence for physicians - reply. JAMA, 320(2), 205-206. https://doi. org/10.1001/jama.2018.6286

Engel, J., Veit, M., Sinke, C., Heitland, I., Kneer, J., Hillemacher, T., Kruger, T. H. (2019). Same same but different: A clinical characterization of men with hypersexual disorder in the sex@brain study.Journal of Clinical Medicine, 8(2), 1-17. https:/ / doi.org/10.3390/jcm8020157

Eriksen, B. A., Eriksen, C. W. (1974). Effects of noise letters upon identification of a target letter in a non-search task. Perception and Psychophysics, 16, 143-149. https:// doi.org/10.3758/BF03203267

Evenden, J. L. (1999). Varieties of impulsivity. Psychopharmacology, 146(4), 348-361. https://doi.org/10.1007/p100005481

Extremera, N., Fernández-Berrocal, P. (2005). Perceived emotional intelligence and life satisfaction: Predictive and incremental validity using the Trait Meta-Mood Scale. Personality and Individual Differences, 39(5), 937-948. https://doi. org/10.1016/j.paid.2005.03.012

Fan, J., McCandliss, B. D., Sommer, T., Raz, A., Posner, M. I. (2002). Testing the efficiency and independence of attentional networks. Journal of Cognitive Neuroscience, 14(3), 340-347. https://doi.org/10.1162/089892902317361886

Firth, J., Torous, J., Stubbs, B., Firth, J. A., Steiner, G. Z., Smith, L., Sarris, J. (2019). The „online brain”: How the Internet may be changing our cognition. World Psychiatry, 18(2), 119-129. https://doi.org/10.1002/wps.20617

Forbush, K., Shaw, M., Graeber, M., Hovick, L., Meyer, V. J., Moser, D. J., ..., Black, D. W. (2008). Neuropsychological characteristics and personality traits in pathological gambling. CNS Spectrums, 13(4), 306-315. https://doi.org/10.1017/ s1092852900016424

Friedman, N. P., Miyake, A. (2017). Unity and diversity of executive functions: Individual differences as a window on cognitive structure. Cortex, 86, 186-204. https://doi.org/10.1016/j.cortex.2016.04.023

Fu, J., Xu, P., Zhao, L., Yu, G. (2018). Impaired orienting in youth with Internet addiction: Evidence from the Attention Network Task (ANT). Psychiatry Research, 264, 54-57. https://doi.org/10.1016/j.psychres.2017.11.071

Gaboury, A., Ladouceur, R. (1989). Erroneous perceptions and gambling. Journal of Social Behavior and Personality, 4, 411-420.

Garland, E. L., Hanley, A. W., Bedford, C. E., Zubieta, J. K., Howard, M. O., Nakamura, Y., Froeliger, B. (2018). Reappraisal deficits promote craving and emotional distress among chronic pain patients at risk for prescription opioid misuse. Journal 
of Addictive Diseases, 37(1-2), 14-22. https://doi.org/10.1080/10550887.2018.14 59148

Giugliano, J. R. (2008). Sexual impulsivity, compulsivity or dependence: An investigative inquiry. Sexual Addiction \& Compulsivity, 15(2), 139-157. https://doi. org/10.1080/10720160802035600

Giugliano, J. R. (2009). Sexual addiction: Diagnostic problems. International Journal of Mental Health and Addiction, 7(2), 283-294. https:/ /doi.org/10.1007/s11469-0099195-3

Gola, M., Potenza, M. N. (2016). Paroxetine treatment of problematic pornography use: A case series. Journal of Behavioral Addictions, 5(3), 529-532. https://doi. org/10.1556/2006.5.2016.046

Gola, M., Wordecha, M., Marchewka, A., Sescousse, G. (2016). Visual sexual stimuli - cue or reward? A perspective for interpreting brain imaging findings on human sexual behaviors. Frontiers in Human Neuroscience, 10, 402. https://doi.org/10.3389/ fnhum.2016.00402

Gola, M., Wordecha, M., Sescousse, G., Lew-Starowicz, M., Kossowski, B., Wypych, M., Marchewka, A. (2017). Can pornography be addictive? An fMRI study of men seeking treatment for problematic pornography use. Neuropsychopharmacology, 42(10), 2021-2031. https://doi.org/10.1038/npp.2017.78

Gong, X., Zhu, R. (2019). Cognitive abilities, non-cognitive skills, and gambling behaviors. Journal of Economic Behavior \& Organization, 165, 51-69. https://doi. org/10.1016/j.jebo.2019.06.016

Goschke, T., Bolte, A. (2014). Emotional modulation of control dilemmas: The role of positive affect, reward, and dopamine in cognitive stability and flexibility. Neuropsychologia, 62, 403-423. https://doi.org/10.1016/j.neuropsychologia.2014.07.015

Gottfredson, L. (1997). Mainstream science on intelligence: An editorial with 52 signatories, history, and bibliography. Intelligence, 24(1), 13-23. https://doi.org/10.1016/ S0160-2896(97)90011-8

Goudriaan, A. E., Oosterlaan, J., de Beurs, P., van den Brink, W. (2006). Neurocognitive deficits in pathological gambling and related disorders. European Neuropsychopharmacology, 16. https://doi.org/10.1016/S0924-977X(06)70064-5

Grant, J. E., Atmaca, M., Fineberg, N. A., Fontenelle, L. F., Matsunaga, H., Janardhan Reddy, Y. C., ..., Stein, D. J. (2014). Impulse control disorders and „behavioural addictions" in the ICD-11. World Psychiatry, 13(2), 125-127. https://doi. org/10.1002/wps.20115

Grant, J. E., Chamberlain, S. R. (2014). Impulsive action and impulsive choice across substance and behavioral addictions: Cause or consequence? Addictive Behaviors, 39(11), 1632-1639. https://doi.org/10.1016/j.addbeh.2014.04.022 
Grant, J. E., Chamberlain, S. R. (2016). Expanding the definition of addiction: DSM-5 vs. ICD-11. CNS Spectrums, 21(4), 300-303. https://doi.org/10.1017/ S1092852916000183

Grant, J. E., Potenza, M. N. (2006). Compulsive aspects of impulse-control disorders. Psychiatric Clinics, 29(2), 539-551. https://doi.org/10.1016/j.psc.2006.02.002

Grant, J. E., Potenza, M. N., Weinstein, A., Gorelick, D. A. (2010). Introduction to behavioral addictions. The American Journal of Drug and Alcohol Abuse, 36(5), 233-241. https://doi.org/10.3109/00952990.2010.491884

Griffiths, M. (1996). Behavioural addiction: An issue for everybody? Employee Counselling Today, 8(3), 19-25. https://doi.org/10.1108/13665629610116872

Hahmann, T. (2016). Moderate-risk and problem slot machine gamblers: A typology of gambling-related cognitions. Journal of Gambling Issues, 34, 140-156. https:/ / doi.org/10.4309/jgi.2016.34.8

Haier, R. J., Jung, R. E., Yeo, R. A., Head, K., Alkire, M. T. (2004). Structural brain variation and general intelligence. Neuroimage, 23(1), 425-433. https://doi. org/10.1016/j.neuroimage.2004.04.025

Hashemi, S. G. S., Shalchi, B., Yaghoubi, H. (2018). Difficulties in emotion regulation, psychological well-being, and hypersexuality in patients with substance use disorder in Iran. Iranian Journal of Psychiatry and Behavioral Sciences, 12(1), e10449. https:/ / doi.org/10.5812/ijpbs.10449

Hinson, J. M., Jameson, T. L., Whitney, P. (2003). Impulsive decision making and working memory. Journal of Experimental Psychology: Learning, Memory, and Cognition, 29(2), 298-306. https://doi.org/10.1037/0278-7393.29.2.298

Hirschman, E. C., Holbrook, M. B. (1982). Hedonic consumption: Emerging concepts, methods and propositions. Journal of Marketing, 48, 92-101. https://doi. org/10.2307/1251707

Holden, C. (2001). 'Behavioral' addictions: Do they exist? Science, 294(5544), 980-982. https://doi.org/10.1126/science.294.5544.980

Kalichman, S. C., Johnson, J. R., Adair, V., Rompa, D., Multhauf, K., Kelly, J. A. (1994). Sexual sensation seeking: Scale development and predicting AIDS-risk behavior among homosexually active men. Journal of Personality Assessment, 62(3), 385-397. https://doi.org/10.1207/s15327752jpa6203_1

Kaplan, H. S. (2013). Sexual desire disorders: Dysfunctional regulation of sexual motivation. Abingdon: Routledge.

Karim, R., Chaudhri, P. (2012). Behavioral addictions: An overview. Journal of Psychoactive Drugs, 44(1), 5-17. https:/ / doi.org/10.1080/02791072.2012.662859 
Kaur, I., Schutte, N., Thorsteinsson, E. (2006). Gambling control self-efficacy as a mediator of the effects of low emotional intelligence on problem gambling. Journal of Gambling Studies, 22(4), 405-411. https://doi.org/10.1007/s10899-006-9029-1

Klucken, T., Wehrum-Osinsky, S., Schweckendiek, J., Kruse, O., Stark, R. (2016). Altered appetitive conditioning and neural connectivity in subjects with compulsive sexual behavior. The Journal of Sexual Medicine, 13(4), 627-636. https://doi. org/10.1016/j.jsxm.2016.01.013

Kober, H. (2014). Emotion regulation in substance use disorders. W: J. J. Gross (red.), Handbook of emotion regulation (s. 428-446). Nowy Jork: The Guilford Press.

Kokkinakis, A. V., Cowling, P. I., Drachen, A., Wade, A. R. (2017). Exploring the relationship between video game expertise and fluid intelligence. PLoS One, 12(11), e0186621. https://doi.org/10.1371/journal.pone.0186621

Kor, A., Fogel, Y. A., Reid, R. C., Potenza, M. N. (2013). Should hypersexual disorder be classified as an addiction? Sexual Addiction \& Compulsivity, 20(1-2), 27-47. https://doi.org/10.1080/10720162.2013.768132

Kowalewska, E., Grubbs, J. B., Potenza, M. N., Gola, M., Draps, M., Kraus, S. W. (2018). Neurocognitive mechanisms in compulsive sexual behavior disorder. Current Sexual Health Reports, 10(4), 255-264. https://doi.org/10.1007/s11930-0180176-z

Kowalewska, E., Kraus, S. W., Lew-Starowicz, M., Gustavsson, K., Gola, M. (2019). Which dimensions of human sexuality are related to compulsive sexual behavior disorder (CSBD)? Study using a multidimensional sexuality questionnaire on a sample of Polish males. The Journal of Sexual Medicine, 16(8), 1264-1273. https:// doi.org/10.1016/j.jsxm.2019.05.006

Kraus, S. W., Krueger, R. B., Briken, P., First, M. B., Stein, D. J., Kaplan, M. S., Reed, G. M. (2018). Compulsive sexual behaviour disorder in the ICD-11. World Psychiatry, 17(1), 109-110. https://doi.org/10.1002/wps.20499

Kraus, S. W., Voon, V., Potenza, M. N. (2016). Should compulsive sexual behavior be considered an addiction? Addiction, 111(12), 2097-2106. https://doi.org/10.1111/ add. 13297

Kraus, S., Rosenberg, H. (2014). The pornography craving questionnaire: Psychometric properties. Archives of Sexual Behavior, 43(3), 451-462. https:/ / doi.org/10.1007/ s10508-013-0229-3

Kun, B., Demetrovics, Z. (2010). Emotional intelligence and addictions: A systematic review. Substance Use \& Misuse, 45(7-8), 1131-1160. https://doi. org/10.3109/10826080903567855 
Kuss, D. J., Pontes, H. M., Griffiths, M. D. (2018). Neurobiological correlates in Internet gaming disorder: A systematic literature review. Frontiers in Psychiatry, 9, 166. https:// doi.org/10.3389/ fpsyt.2018.00166

Laier, C., Pawlikowski, M., Brand, M. (2014). Sexual picture processing interferes with decision-making under ambiguity. Archives of Sexual Behavior, 43, 473-482. https:/ / doi.org/10.1007/s10508-013-0119-8

Laier, C., Pawlikowski, M., Pekal, J., Schulte, F. P., Brand, M. (2013). Cybersex addiction: Experienced sexual arousal when watching pornography and not real-life sexual contacts makes the difference. Journal of Behavioral Addictions, 2(2), 100-107. https://doi.org/10.1556/JBA.2.2013.002

Laier, C., Pekal, J., Brand, M. (2014). Cybersex addiction in heterosexual female users of Internet pornography can be explained by gratification hypothesis. Cyberpsychology, Behavior, and Social Networking, 17(8), 505-511. https://doi.org/10.1089/ cyber.2013.0396

Langrehr, F. W. (1991). Retail shopping mall semiotics and hedonic consumption. Advances in Consumer Research, 18, 428-433.

Leeman, R. F., Potenza, M. N. (2013). A targeted review of the neurobiology and genetics of behavioural addictions: An emerging area of research. The Canadian Journal of Psychiatry, 58(5), 260-273. https://doi.org/10.1177/070674371305800503

Lejoyeux, M., Weinstein, A. (2010). Compulsive buying. The American Journal of Drug and Alcohol Abuse, 36(5), 248-253. https://doi.org/10.3109/00952990.2010.493 590

Lewczuk, K., Nowakowska, I., Lewandowska, K., Potenza, M., Gola, M. (2021). Frequency of use, moral incongruence and religiosity and their relationships with self-perceived addiction to pornography, internet use, social networking and online gaming. Addiction, 116(4), 889-899. https://doi.org/10.1111/add.15272

Lin, C., Chuang, S. (2005). The effect of individual differences on adolescents' impulsive buying behavior. Adolescence, 40(159), 551-558.

Liu, G. C., Yen, J. Y., Chen, C. Y., Yen, C. F., Chen, C. S., Lin, W. C., Ko, C. H. (2014). Brain activation for response inhibition under gaming cue distraction in Internet gaming disorder. The Kaobsiung Journal of Medical Sciences, 30(1), 43-51. https://doi. org/10.1016/j.kjms.2013.08.005

Lo, H. Y., Harvey, N. (2011). Shopping without pain: Compulsive buying and the effects of credit card availability in Europe and the Far East. Journal of Economic Psychology, 32(1), 79-92. https://doi.org/10.1016/j.joep.2010.12.002

Logan, G. D., Cowan, W. B. (1984). On the ability to inhibit thought and action: A theory of an act of control. Psychological Review, 91(3), 295-327. https://doi. org/10.1037/0033-295X.91.3.295 
Mallorquí-Bagué, N., Tolosa-Sola, I., Fernandez-Aranda, F., Granero, R., Fagundo, A., Lozano-Madrid, A., ..., Jiménez-Murcia, S. (2018). Cognitive deficits in executive functions and decision making impairments cluster gambling disorder sub-types. Journal of Gambling Studies, 34(1), 209-223. https://doi.org/10.1007/s10899-0179724-0

Martinez-Pina, A., de Parga, J. L., Vallverdu, R. F., Planas, X. S., Mateo, M. M., Aguado, V. M. (1991). The Catalonia survey: Personality and intelligence structure in a sample of compulsive gamblers. Journal of Gambling Studies, 7(4), 275-299. https:// doi.org/10.1007/BF01023747

Martins, A., Ramalho, N., Morin, E. (2010). A comprehensive meta-analysis of the relationship between emotional intelligence and health. Personality and Individual Differences, 49(6), 554-564. https://doi.org/10.1016/j.paid.2010.05.029

May, R. K., Whelan, J. P., Steenbergh, T. A., Meyers, A. W. (2003). The gambling self-efficacy questionnaire: An initial psychometric evaluation. Journal of Gambling Studies, 19, 339-356. https://doi.org/10.1023/a:1026379125116

McElroy, S., Phillips, K., Keck, P. (1994). Obsessive compulsive spectrum disorder. Journal of Clinical Psychiatry, 55, 33-53.

McNamara, J., Vervaeke, S., Willoughby, T. (2008). Learning disabilities and risk-taking behavior in adolescents: A comparison of those with and without comorbid attention-deficit/hyperactivity disorder. Journal of Learning Disabilities, 41, 561-574. https://doi.org/10.1177/0022219408326096

Meiran, N. (2010). Task switching: Mechanisms underlying rigid vs. flexible self control. W: R. Hassin, K. Ochsner, Y. Trope (red.), Self control in society, Mind and brain (s. 202-220). Nowy Jork: Oxford University Press. https://doi.org/10.1093/acprof:oso/9780195391381.003.0011

Messina, B., Fuentes, D., Tavares, H., Abdo, C. H., Scanavino, M. D. T. (2017). Executive functioning of sexually compulsive and non-sexually compulsive men before and after watching an erotic video. The Journal of Sexual Medicine, 14(3), 347-354. https://doi.org/10.1016/j.jsxm.2016.12.235

Miyake, A., Friedman, N. P., Emerson, M. J., Witzki, A. H., Howerter, A., Wager, T. D. (2000). The unity and diversity of executive functions and their contributions to complex „frontal lobe” tasks: A latent variable analysis. Cognitive Psychology, 41(1), 49-100. https://doi.org/10.1006/cogp.1999.0734

Montgomery-Graham, S. (2017). Conceptualization and assessment of hypersexual disorder: A systematic review of the literature. Sexual Medicine Reviews, 5(2), 146-162. https://doi.org/10.1016/j.sxmr.2016.11.001

Morris, L., Mansell, W. (2018). A systematic review of the relationship between rigidity/flexibility and transdiagnostic cognitive and behavioral processes that maintain 
psychopathology. Journal of Experimental Psychopathology, 9(3), 1-40. https://doi. org/10.1177/2043808718779431

Moskalewicz, J., Badora, B., Feliksiak, M., Głowacki, A., Gwiazda, M., Herrmann, M., ..., Roguska, B. (2019). Oszacowanie rozpowsžechnienia oraz identyfikacja caynnikón rysyka i csynnikón chroniacych hazardu i innych uzależnień behawioralnych - edycja 2018/2019. Raport z badań. Warszawa: Centrum Badania Opinii Społecznej.

Muda, R., Śliwińska, P., Pawelec, A. (2014). I-graj z losem dzięki zdolnościom. Różnice w cechach osobowości i zdolnościach poznawczych między pokerzystami zawodowymi, rekreacyjnymi i osobami niegrajacymi w pokera. Psychologia Ekonomiczৃa, 5, 26-38. https://doi.org/10.14659/PJOEP.2014.05.02

Mulhauser, K. R., Struthers, W. M., Hook, J. N., Pyykkonen, B. A., Womack, S. D., MacDonald, M. (2014). Performance on the Iowa Gambling Task in a sample of hypersexual men. Sexual Addiction \& Compulsivity, 21(2), 170-183. https://doi.org /10.1080/10720162.2014.908333

Newman, D. A., Joseph, D. L., MacCann, C. (2010). Emotional intelligence and job performance: The importance of emotion regulation and emotional labor context. Industrial and Organizational Psychology, 3(2), 159-164. https://doi.org/10.1111/ j.1754-9434.2010.01218.x

Nęcka, E., Orzechowski, J., Szymura, B. (2006). Psychologia poznancza. Warszawa: Wydawnictwo Naukowe PWN.

Nicholson, R., Graves, C., Ellery, M., Afifi, T. (2016). The temporal relationship between faulty gambling cognitions and gambling severity in young adults. Journal of Gambling Studies, 32, 1215-1229. https://doi.org/10.1007/s10899-016-9605-y

Nowakowska, I., Lewczuk, K., Gola, M. (2020). Changes in the addiction prevalence in Polish population between 1990-2019: Review of available data. Journal of Addiction Science, 6(1), 17-31. https://doi.org/10.17756/jas.2020-045

O’Boyle, E. H., Jr., Humphrey, R. H., Pollack, J. M., Hawver, T. H., Story, P. A. (2011). The relation between emotional intelligence and job performance: A meta-analysis. Journal of Organizational Behavior, 32(5), 788-818. https://doi.org/10.1002/ job.714

O’Guinn, T. C., Faber, R. J. (1989). Compulsive buying: A phenomenological exploration. Journal of Consumer Research, 16, 147-157. https://doi.org/10.1086/209204

Ogińska-Bulik, N. (2016). Kompulsywne kupowanie. W: B. Habrat (red.), Zaburzenia uprawiania hazardu i inne tak zwane natogi behawioralne (s. 379-406). Warszawa: Instytut Psychiatrii i Neurologii.

Pachankis, J. E., Rendina, H. J., Ventuneac, A., Grov, C., Parsons, J. T. (2014). The role of maladaptive cognitions in hypersexuality among highly sexually active gay and 
bisexual men. Archives of Sexual Behavior, 43(4), 669-683. https://doi.org/10.1007/ s10508-014-0261-y

Pajestka, G., Skałacka, K., Wirga, T. (2018). Test R-W jako trafne narzędzie w badaniach przesiewowych z zakresu psychologii pracy. Czasopismo Psychologiczne - Psychological Journal, 24(3), 585-593. https://doi.org/10.14691/CPPJ.24.3.585

Park, H., Dhandra, T. (2017). Relation between dispositional mindfulness and impulsive buying tendency: Role of trait emotional intelligence. Personality and Individual Differences, 105, 208-212. https://doi.org/10.1016/j.paid.2016.09.061

Park, M., Park, E., Choi, J., Chai, S., Lee J., Lee, C., Kim, D. (2011). Preliminary study of Internet addiction and cognitive function in adolescents based on IQ tests. Psychiatry Research, 190(2-3), 275-281. https://doi.org/10.1016/j.psychres.2011.08.006

Parke, A., Harris, A., Parke, J., Goddard, P. (2016). Understanding within-session loss-chasing: An experimental investigation of the impact of stake size on cognitive control. Journal of Gambling Studies, 32, 721-735. https://doi.org/10.1007/ s10899-015-9570-x

Parker, J. D., Creque, R. E., Sr., Barnhart, D. L., Harris, J. I., Majeski, S. A., Wood, L. M., Hogan, M. J. (2004). Academic achievement in high school: Does emotional intelligence matter? Personality and Individual Differences, 37(7), 1321-1330. https:// doi.org/10.1016/j.paid.2004.01.002

Payne, J. W., Payne, J. W., Bettman, J. R., Johnson, E. J. (1993). The adaptive decision maker. Nowy Jork: Cambridge University Press. https://doi.org/10.1017/ CBO9781139173933

Peter, P., Krishnakumar, S. (2010). Emotional intelligence, impulse buying and self-esteem: The predictive validity of two ability measures of emotional intelligence. Advances in Consumer Research, 37, 877-878.

Pies, R. (2009). Should DSM-V designate „Internet addiction” a mental disorder? Psychiatry (Edgmont), 6(2), 31-37.

Ramey, T., Regier, P. S. (2018). Cognitive impairment in substance use disorders. CNS Spectrums, 24(1), 102-113. https://doi.org/10.1017/S1092852918001426

Ranjbar, M., Montazerfaraj, R., Pourmahmoodian, M. (2018). The relationship between emotional intelligence with general health and academic achievement: A case study in Iran's health system. Bali Medical Journal, 7(2), 505-510. https:// doi.org/10.15562/bmj.v7i2.750.

Raudsepp, M., Parts, O. (2014). Compulsive buying in Estonia. Procedia - Social and Behavioral Sciences, 156, 414-417. https://doi.org/10.1016/j.sbspro.2014.11.213

Reid, R. C., Carpenter, B. N., Hook, J. N., Garos, S., Manning, J. C., Gilliland, R., Fong, T. (2012). Report of findings in a DSM-5 field trial for hypersexual disorder. The 
Journal of Sexual Medicine, 9(11), 2868-2877. https://doi.org/10.1111/j.17436109.2012.02936.x

Reid, R. C., Garos, S., Carpenter, B. N. (2011). Reliability, validity, and psychometric development of the Hypersexual Behavior Inventory in an outpatient sample of men. Sexual Addiction \& Compulsivity, 18(1), 30-51. https://doi.org/10.1080/107 20162.2011.555709

Reid, R. C., Garos, S., Carpenter, B. N., Coleman, E. (2011). A surprising finding related to executive control in a patient sample of hypersexual men. The Journal of Sexual Medicine, 8(8), 2227-2236. https://doi.org/10.1111/j.1743-6109.2011.02314.x

Reid, R. C., Kafka, M. P. (2014). Controversies about hypersexual disorder and the DSM-5. Current Sexual Health Reports, 6(4), 259-264. https://doi.org/10.1111/ j.1743-6109.2012.02936.x

Reid, R. C., Karim, R., McCrory, E., Carpenter, B. N. (2010). Self-reported differences on measures of executive function and hypersexual behavior in a patient and community sample of men. International Journal of Neuroscience, 120(2), 120-127. https://doi.org/10.3109/00207450903165577

Rick, S. I., Pereira, B., Burson, K. A. (2014). The benefits of retail therapy: Making purchase decisions reduces residual sadness. Journal of Consumer Psychology, 24(3), 373-380. https://doi.org/10.1016/j.jcps.2013.12.004

Robbins, T. W., Clark, L. (2015). Behavioral addictions. Current Opinion in Neurobiology, 30, 66-72. https://doi.org/10.1016/j.conb.2014.09.005

Roberts, J. A. (1998). Compulsive buying among college students: An investigation of its antecedents, consequences, and implications for public policy. Journal of Consumer Affairs, 32(2), 295-319. https://doi.org/10.1111/j.1745-6606.1998.tb00411.x

Rochat, L., Beni, C., Billieux, J., Annoni, J.-M., Van der Linden, M. (2011). How impulsivity relates to compulsive buying and the burden perceived by caregivers after moderate-to-severe traumatic brain injury. Psychopathology, 44(3), 158-164. https:// doi.org/10.1159/000322454

Rogier, G., Velotti, P. (2018). Conceptualizing gambling disorder with the process model of emotion regulation. Journal of Behavioral Addictions, 7(2), 239-251. https://doi.org/10.1556/2006.7.2018.52

Rose, P., Segrist, D. (2012). Difficulty identifying feelings, distress tolerance and compulsive buying: Analyzing the associations to inform therapeutic strategies. International Journal of Mental Health and Addiction, 10(6), 927-935. https://doi. org/10.1007/s11469-012-9389-y

Rose, S., Yudham, A. D. (2013). Towards an understanding of Internet-based problem shopping behaviour: The concept of online shopping addiction and its proposed 
predictors. Journal of Behavioral Addictions, 3(2), 83-89. https://doi.org/10.1556/ JBA.3.2014.003

Salovey, P., Mayer, J. D. (1990). Emotional intelligence. Imagination, Cognition and Personality, 9(3), 185-211. https://doi.org/10.2190/DUGG-P24E-52WK-6CDG

Schachar, R., Logan, G. D., Robaey, P., Chen, S., Ickowicz, A., Barr, C. (2007). Restraint and cancellation: Multiple inhibition deficits in attention deficit hyperactivity disorder. Journal of Abnormal Child Psychology, 35(2), 229-238. https://doi. org/10.1007/s10802-006-9075-2

Schiebener, J., Laier, C., Brand, M. (2015). Getting stuck with pornography? Overuse or neglect of cybersex cues in a multitasking situation is related to symptoms of cybersex addiction. Journal of Behavioral Addictions, 4(1), 14-21. https://doi. org/10.1556/JBA.4.2015.1.5

Schutte, N. S., Malouff, J. M., Hall, L. E., Haggerty, D. J., Cooper, J. T., Golden, C. J., Dornheim, L. (1998). Development and validation of a measure of emotional intelligence. Personality and Individual Differences, 25, 167-177. https://doi. org/10.1016/S0191-8869(98)00001-4

Seo, M., Kang, H. S., Chae, S. M. (2012). Emotional competence and online game use in adolescents. CIN: Computers, Informatics, Nursing, 30(12), 640-646. https://doi. org/10.1097/NXN.0b013e318261f1a6

Seok, J. W., Lee, K. H., Sohn, S., Sohn, J. H. (2015). Neural substrates of risky decision making in individuals with Internet addiction. Australian \& New Zealand Journal of Psychiatry, 49(10), 923-932. https://doi.org/10.1177/0004867415598009

Shamosh, N. A., DeYoung, C. G., Green, A. E., Reis, D. L., Johnson, M. R., Conway, A. R., ..., Gray, J. R. (2008). Individual differences in delay discounting: Relation to intelligence, working memory, and anterior prefrontal cortex. Psycbological Science, 19(9), 904-911. https://doi.org/10.1111/j.1467-9280.2008.02175.x

Shams, T. A., Foussias, G., Zawadzki, J. A., Marshe, V. S., Siddiqui, I., Müller, D. J., Wong, A. H. (2015). The effects of video games on cognition and brain structure: Potential implications for neuropsychiatric disorders. Current Psychiatry Reports, 17(9), 71. https://doi.org/10.1007/s11920-015-0609-6

Sharpe, L. (2002). A reformulated cognitive-behavioral model of problem gambling. Clinical Psychology Review, 22(1), 1-25. https://doi.org/10.1016/s02727358(00)00087-8

Shenassa, E. D., Paradis, A. D., Dolan, S. L., Wilhelm, C. S., Buka, S. L. (2012). Childhood impulsive behavior and problem gambling by adulthood: A 30-year prospective community- based study. Addiction, 107(1), 160-168. https://doi. $\operatorname{org} / 10.1111 / j .1360-0443.2011 .03571 . x$ 
Silczuk, A., Habrat, B. (2016). Zaburzenia uprawiania hazardu. W: B. Habrat (red.), Zaburzenia uprawiania hazardu i inne tak zwane natogi behawioralne (s. 83-152). Warszawa: Instytut Psychiatrii i Neurologii.

Snagowski, J., Brand, M. (2015). Symptoms of cybersex addiction can be linked to both approaching and avoiding pornographic stimuli: Results from an analog sample of regular cybersex users. Frontiers in Psychology, 6, 653. https:/ / doi. org/10.3389/ fpsyg.2015.00653

Snagowski, J., Laier, C., Duka, T., Brand, M. (2016). Subjective craving for pornography and associative learning predict tendencies towards cybersex addiction in a sample of regular cybersex users. Sexual Addiction \& Compulsivity, 23(4), 342-360. https:// doi.org/10.1080/10720162.2016.1151390

Son, K. L., Choi, J. S., Lee, J., Park, S. M., Lim, J. A., Lee, J. Y., Kwon, J. S. (2015). Neurophysiological features of Internet gaming disorder and alcohol use disorder: A resting-state EEG study. Translational Psychiatry, 5(9), e628. https://doi. org/10.1038/tp.2015.124

Spearman, C. (1925). Some issues in the theory of „g” (including the law of diminishing returns). Nature, 116(2916), 436-439. https://doi.org/10.1038/116436a0

Starcevic, V., Khazaal, Y. (2017). Relationships between behavioural addictions and psychiatric disorders: What is known and what is yet to be learned? Frontiers in Psychiatry, 8, 53. https://doi.org/10.3389/fpsyt.2017.00053

Stark, R., Klucken, T., Potenza, M. N., Brand, M., Strahler, J. (2018). A current understanding of the behavioral neuroscience of compulsive sexual behavior disorder and problematic pornography use. Current Behavioral Neuroscience Reports, 5(4), 218-231. https://doi.org/10.1007/s40473-018-0162-9

Sternberg, R. J. (red.). (2000). Handbook of intelligence. Cambridge: Cambridge University Press. https://doi.org/10.1017/CBO9780511807947

Sun, T., Wu, G. (2011). Trait predictors of online impulsive buying tendency: A hierarchical approach. Journal of Marketing Theory and Practice, 19(3), 337-346. https:// doi.org/10.2753/MTP1069-6679190307

Sun, D. L., Chen, Z. J., Ma, N., Zhang, X. C., Fu, X. M., Zhang, D. R. (2009). Decision-making and prepotent response inhibition functions in excessive Internet users. CNS Spectrums, 14(2), 75-81. https://doi.org/10.1017/s1092852900000225

Takeuchi, H., Taki, Y., Asano, K., Asano, M., Sassa, Y., Yokota, S., Kawashima, R. (2018). Impact of frequency of Internet use on development of brain structures and verbal intelligence: Longitudinal analyses. Human Brain Mapping, 39(11), 4471-4479. https://doi.org/10.1002/hbm.24286 
Tao, R., Huang, X., Wang, J., Zhang, H., Zhang, Y., Li, M. (2010). Proposed diagnostic criteria for Internet addiction. Addiction, 105(3), 556-564. https://doi. org/10.1111/j.1360-0443.2009.02828.x

Taylor, R., Parker, J., Keefer, K., Kloosterman, P., Summerfeldt, L. (2015). Gambling related cognitive distortions in adolescence: Relationships with gambling problems in typically developing and special needs students. Journal of Gambling Studies, 31, 1417-1429. https://doi.org/10.1007/s10899-014-9480-3

Tekin, A., Yetkin, A., Adigüzel, S., Akman, H. (2018). Evaluation of Stroop and Trail-Making Tests performance in university students with Internet addiction. Anatolian Journal of Psychiatry, 19(6), 593-598. https://doi.org/10.5455/apd.292389

Tomorowicz, A. (2011). Struktura kompetencji społecznych w ujęciu interakcyjnym. Psychiatria, 8(3), 91-96.

Truszczyński, O., Różanowski, K., Baran, P., Lewandowski, J. (2012). Wartość predykcyjna inteligencji w badaniach sprawności psychomotorycznej kierujących pojazdami. Przeglad Psychologiczny, 55(4), 397-410.

Tsaousis, I., Nikolaou, I. (2005). Exploring the relationship of emotional intelligence with physical and psychological health functioning. Stress and Health: Journal of the International Society for the Investigation of Stress, 21(2), 77-86. https://doi. org/10.1002/smi.1042

Tyszkowska, M. (2017). Metaanaliza krytycznego dyskursu nad teorią wielorakich inteligencji Howarda Gardnera. Przeglad Badań Edukacyjnych, 24, 137-149. https:/ / doi.org/10.12775/PBE.2017.008

Vandervoort, D. J. (2006). The importance of emotional intelligence in higher education. Current Psychology, 25(1), 4-7. https://doi.org/10.1007/s12144-006-1011-7

Weinstein, A. M., Zolek, R., Babkin, A., Cohen, K., Lejoyeux, M. (2015). Factors predicting cybersex use and difficulties in forming intimate relationships among male and female users of cybersex. Frontiers in Psychiatry, 6, 54. https://doi.org/10.3389/ fpsyt.2015.00054

Wordecha, M., Wilk, M., Kowalewska, E., Skorko, M., Łapiński, A., Gola, M. (2018). „Pornographic binges” as a key characteristic of males seeking treatment for compulsive sexual behaviors: Qualitative and quantitative 10-weeklong diary assessment. Journal of Behavioral Addictions, 7(2), 433-444. https:/ / doi. org/10.1556/2006.7.2018.33

World Health Organization (2019). International Classification of Diseases ICD-11. Pobrane z: https://icd.who.int/en (data dostępu: 25.09.2019).

Yen, C.-F., Ko, C.-H., Yen, J.-Y., Chang, Y.-P., Cheng, C.-P. (2009). Multi-dimensional discriminative factors for Internet addiction among adolescents regarding 
gender and age. Psychiatry and Clinical Neurosciences, 63(3), 357-364. https://doi. org/10.1111/j.1440-1819.2009.01969.x

Yılmaz, S., Hergüner, S., Bilgiç, A., Işık, Ü. (2015). Internet addiction is related to attention deficit but not hyperactivity in a sample of high school students. International Journal of Psycbiatry in Clinical Practice, 19(1), 18-23. https://doi.org/10.31 09/13651501.2014.979834

Yoo, H. J., Cho, S. C., Ha, J., Yune, S. K., Kim, S. J., Hwang, J., Lyoo, I. K. (2004). Attention deficit hyperactivity symptoms and Internet addiction. Psychiatry and Clinical Neurosciences, 58(5), 487-494. https://doi.org/10.1111/j.1440-1819.2004.01290.x

Young, K. S. (1996). Psychology of computer use: XL. Addictive use of the Internet: A case that breaks the stereotype. Psychological Reports, 79(3), 899-902. https://doi. org/10.2466/pr0.1996.79.3.899

Zhou, Z., Yuan, G., Yao, J. (2012). Cognitive biases toward Internet game-related pictures and executive deficits in individuals with an Internet game addiction. PLoS One, 7(11), e48961. https://doi.org/10.1371/journal.pone.0048961

Zhou, Z., Zhou, H., Zhu, H. (2016). Working memory, executive function and impulsivity in Internet-addictive disorders: A comparison with pathological gambling. Acta Neuropsychiatrica, 28(2), 92-100. https://doi.org/10.1017/neu.2015.54

Zhou, Z., Zhu, H., Li, C., Wang, J. (2014). Internet addictive individuals share impulsivity and executive dysfunction with alcohol-dependent patients. Frontiers in Behavioral Neuroscience, 8, 288. https://doi.org/10.3389/fnbeh.2014.00288 



\section{5.}

\section{Przekonania na temat}

inteligencji, czyli kto i dlaczego chce być (postrzegany jako) mądry

Marcin Zajenkowski iD https://orcid.org/0000-0001-8669-4231

Uniwersytet Warszawski, Wydział Psychologii

zajenkowski@psych.uw.edu.pl

Oliwia Maciantowicz iD https://orcid.org/0000-0002-3099-5956

Uniwersytet Warszawski, Wydział Psychologii 
$\mathrm{D}$ ługa tradycja badań nad inteligencją pokazuje jej doniosłe znaczenie w wielu dziedzinach życia. Wysoki poziom inteligencji jest związany ze statusem społecznym, sukcesem szkolnym, osiagnięciami w pracy a nawet dobrym zdrowiem i długim życiem (Gottfredson, 2002; zob. też: rozdział $1 \mathrm{w}$ tym tomie). Być może z powodu tak dużego znaczenia inteligencji dla życia stała się ona ważnym pojęciem we współczesnym świecie. Wiąże się to z faktem, że nie tylko sam poziom rzeczywistej inteligencji odgrywa dużą rolę w życiu człowieka, ale także przekonania na jej temat mają duże znaczenie dla naszego codziennego funkcjonowania (Howard, Cogswell, 2018). Innymi słowy, to, co ludzie myślą o swojej inteligencji i jak szacuja jej poziom, przekłada się na wiele elementów naszego życia, takich jak ogólna samoocena, poczucie zadowolenia czy osiagnięcia akademickie (Chamorro-Premuzic, Furnham, 2006). Z drugiej strony, pojęć związanych z intelektem używamy czasem w celu poniżenia innych, np. poprzez nazwanie kogoś głupkiem czy idiotą. Negatywne społecznie zjawiska związane z inteligencją mogą się z kolei przekładać na stygmatyzowanie określonych grup i tworzenie stereotypów. Podstawowe pytanie, jakie warto w tym kontekście rozważyć, dotyczy tego, na ile jesteśmy w stanie adekwatnie oszacować poziom własnej inteligencji oraz inteligencji innych osób.

\section{CO WIEMY O WŁASNEJ INTELIGENCJI?}

Badania w obszarze trafności szacowania przez ludzi poziomu inteligencji najczęściej polegają na tym, że osoby proszone są o ocenę poziomu tej charakterystyki lub bardziej szczegółowych zdolności wchodzących w jej zakres (np. werbalnych, przestrzennych itp.) w porównaniu do innych ludzi. Na przykład prosi się badanych o określenie (zob. rysunek 1), czy w porównaniu do innych ich poziom inteligencji jest niski, średni czy wysoki (Zajenkowski, Stolarski, Maciantowicz, Malesza, Witowska, 2016). Dodatkowo osoby badane wypełniają standardowe testy inteligencji. W ten sposób można zestawić to, co osoba myśli o sobie, z jej rzeczywistymi wynikami testów IQ. Warto zauważyć, że w przeciwieństwie do wielu innych cech psychologicznych (np. cech osobowo- 
ści), w przypadku inteligencji dysponujemy obiektywnym kryterium w postaci poziomu wykonania testów inteligencji.

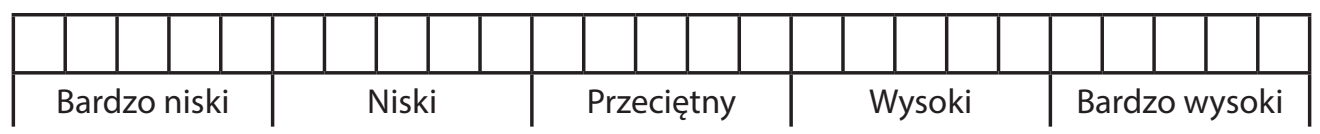

Rysunek 1. Skala do pomiaru subiektymnie ocenianej inteligencji. Osoba badana ma wskazać odpowiednia kratke, w której lokuje sie jej poziom inteligencji w porónnaniu do innych ludzi.

Co wynika z tego typu badań? Ludzie, do pewnego stopnia, potrafią oszacować poziom własnej inteligencji. Średnia korelacja między subiektywnie szacowaną a obiektywnie mierzoną inteligencją wynosi ok. 0,30 (Freund, Kasten, 2012). Ten wynik oznacza, że 9\% obserwowanych różnic między ludźmi w zakresie obiektywnej inteligencji pokrywa się z subiektywnym oszacowaniem własnej inteligencji. Nie jesteśmy zatem w stanie w pełni adekwatnie określić jej poziomu. Rzeczywiście, doniesienia empiryczne wskazują na istnienie wielu efektów, które wpływają na zniekształcenia w zakresie postrzegania własnych zdolności.

Jednym z szerzej opisywanych w literaturze zjawisk związanych z postrzeganiem siebie jest tzw. efekt ponadprzeciętności (better-than-average effect). Większość ludzi ma tendencję do postrzegania siebie jako ponadprzeciętnych w zakresie wielu, społecznie pożądanych cech, takich jak atrakcyjność fizyczna, towarzyskość czy uczciwość (Zell, Strickhouser, Sedikides, Alicke, 2020). Efekt ten jest również bardzo wyraźny w odniesieniu do inteligencji, tj. większość osób postrzega się jako ponadprzeciętnie inteligentnych (zob. Gignac, Zajenkowski, 2019). Jedno z podstawowych założeń w psychologii dotyczy tego, że większość cech psychicznych ma rozkład normalny w populacji. Rozkład normalny jest symetryczny, a jego punkt środkowy pokrywa się ze średnia arytmetyczna. Oznacza to, że połowa osób w populacji znajduje się poniżej średniej, a połowa powyżej średniej. Pomimo tego, większość osób lokuje swoją inteligencję (i wiele innych cech) powyżej średniej (Alicke, Govorun, 2005). Jednym z przykładów może być niedawne badanie przeprowadzone na próbie amerykańskiej, w którym poproszono badanych o ustosunkowanie się do stwierdzenia „Jestem bardziej inteligentny(a) niż przeciętna osoba” (Heck, Simons, Chabris, 2018). Okazało się, że 65\% ludzi uznało to stwierdzenie za prawdziwe w odniesieniu do samych siebie. W tym badaniu nie mierzono realnego poziomu inteligencji, mogło się zatem okazać, że w tej właśnie próbie 
rzeczywiście znalazło się wiele osób ponadprzeciętnie inteligentnych. Jednakże wyniki innych badań jednoznacznie wskazują na to, że większość osób ulega pozytywnemu złudzeniu na własny temat (Zell i in., 2020). Testy inteligencji najczęściej zamienia się na iloraz inteligencji, zwany również IQ (intelligence quotient). $Z$ definicji średnia IQ w populacji to 100 , natomiast przeciętne zróżnicowanie między ludźmi (tzw. odchylenie standardowe) to 15 punktów. W jednym z badań stwierdzono, że ludzie przeszacowywali swój poziom IQ o kilka punktów (Reilly, Mulhern, 1995). Natomiast Gignac i Zajenkowski (2019) $\mathrm{w}$ niedawnym badaniu przeprowadzonym na populacji polskiej zaobserwowali, że badani przeszacowywali swoją inteligencję aż o ok. 30 punktów IQ.

Efekt ponadprzeciętności wiąże się ściśle ze zjawiskiem samo-polepszania (selfenhancement), czyli postrzegania siebie w lepszym świetle, niż wskazywałaby na to rzeczywistość. Badacze zwracają uwagę, że nazbyt optymistyczne widzenie siebie dotyczy zwłaszcza pewnych cech (Ferris, Johnson, Sedikides, 2018). Na przykład mamy tendencję do zniekształcania cech, które są stosunkowo niejednoznaczne. Nie jesteśmy w stanie okłamywać się co do własnego wzrostu, ponieważ różnice między ludźmi są w tym zakresie widoczne gołym okiem, natomiast jeżeli chodzi o inteligencję, to, w ogromnej większości przypadków, nie wiemy, jaki ktoś ma rzeczywisty poziom IQ. Dlatego też w tym przypadku oszukiwanie siebie i innych jest łatwiejsze. Efekt przeszacowania własnych zdolności osłabia się, kiedy badani wiedzą, że ich odpowiedź zostanie pokazana bliskim im ludziom (np. przyjaciołom, małżonkom), a zatem osobom, które dobrze ich znają (Ferris i in., 2018).

Interesujące zjawisko związane $z$ wiedzą na temat własnych zdolności opisane jest w literaturze jako efekt Duninnga-Krugera. Zgodnie z nim, osoby o niskim poziomie danej zdolności bardziej przeszacowują swoje zdolności niż osoby, które mają wysoki poziom danej zdolności (Kruger, Dunning, 1999). Innymi słowy, mniej kompetentni wiedzą o sobie mniej niż bardziej kompetentni. Zjawisko to było badane w odniesieniu do wielu różnych umiejętności, takich jak zdolności językowe, rozumowanie logiczne, czy nawet poczucie humoru (Dunning, 2005). Najczęstszym sposobem analizy w tego typu badaniach jest dzielenie osób badanych na cztery grupy ze względu na poziom obiektywnie mierzonej zdolności: $25 \%$ osób o najniższych wynikach, $25 \%$ osób o średnio-niskich wynikach, $25 \%$ osób o średnio-wysokich wynikach i $25 \%$ osób o najwyższych wynikach. Następnie sprawdza się, jak badani znajdujący się w każdej z tych grup subiektywnie szacowali poziom własnych zdolności, co zwyczajowo ilustruje się na wykresie (zob. rysunek 2). Jak można zobaczyć na schematycznym rysunku 2, osoby o niskim poziomie zdolności 
wykazują najczęściej największą rozbieżność między subiektywną oceną własnych zdolności a ich rzeczywistym poziomem. Wraz ze wzrostem obiektywnych zdolności dystans do samoopisowej oceny zmniejsza się.

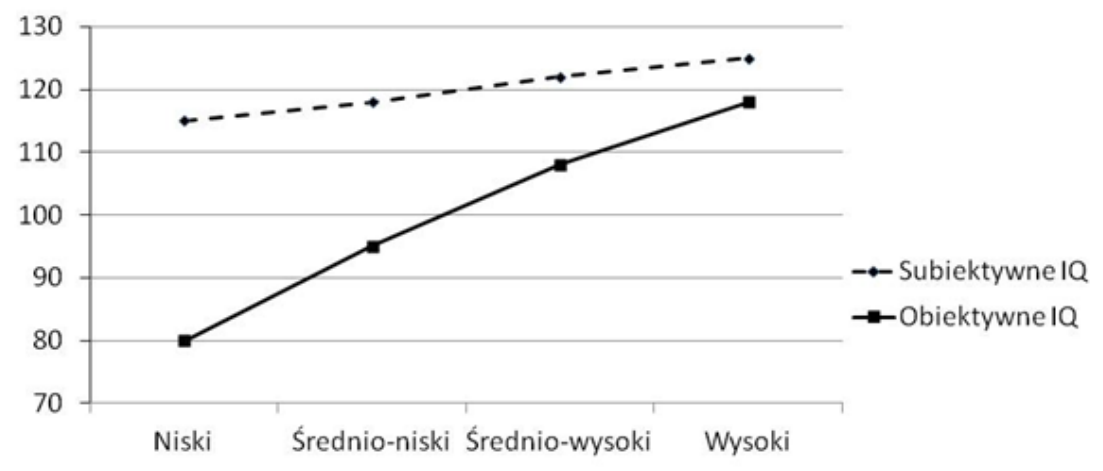

Rysunek 2. Schematyczne przedstawienie efektu Dunninga-Krugera na praylktadzie subiektywnie szacowanej i obiektymnie mierzonej inteligencji.

W niedawnym badaniu Gignac i Zajenkowski (2020) wykazali na przykładzie subiektywnie i obiektywnie mierzonej inteligencji, że efekt DunningaKrugera może być jedynie statystycznym artefaktem, to znaczy, że obserwowane w badaniach efekty da się wytłumaczyć dwoma prostszymi zjawiskami: efektem ponadprzeciętności oraz regresją do średniej. Jak się okazuje, większość ludzi widzi się jako ponadprzeciętnie inteligentnych, do czego zbliżają się obiektywnie mierzone zdolności. Analizy Gignaca i Zajenkowskiego (2020) sugeruja, że na każdym poziomie zdolności rozbieżność między obiektywnie i subiektywnie ocenianą inteligencja jest podobna.

\section{CO WIEMY O INTELIGENCJI INNYCH LUDZI?}

Przedstawione powyżej dane wskazują na to, że ludzie mają tendencję do zniekształconego postrzegania własnych zdolności. W codziennym życiu często wypowiadamy się jednak (pozytywnie lub negatywnie) o intelekcie innych ludzi. Powstaje zatem pytanie, w jakim stopniu jesteśmy w stanie trafnie oszacować inteligencję drugiej osoby. Problem ten może być szczególnie istotny w przypadku par, ponieważ ludzie stawiają inteligencję wysoko w hierarchii, gdy sa pytani o cechy ich idealnego partnera/partnerki; Buss i in., 1990).W jednym z badań Gignac i Zajenkowski (2019) sprawdzali, jak osoby będące ze sobą w związkach oceniają nawzajem swoją inteligencję. Autorzy przebadali 218 
par heteroseksualnych. Każda osoba oceniała subiektywnie własną inteligencję oraz inteligencję partnera/partnerki, a następnie wykonywała Test matryc Ravena będący jednym z najbardziej popularnych testów inteligencji. Okazało się, że partnerzy potrafili w pewnym stopniu adekwatnie oszacować nawzajem swoja inteligencję. Korelacja pomiędzy tym, jak kobiety szacowały inteligencję mężczyzn a rzeczywistym wynikiem w teście mężczyzn wynosiła 0,30 , natomiast w przypadku szacowania partnerek przez mężczyzn i rzeczywistym wynikiem inteligencji wśród kobiet korelacja wynosiła 0,19. Pomimo pewnej różnicy w korelacjach, nie okazała się ona istotna statystycznie. Badacze następnie sprawdzili jak duża jest rozbieżność pomiędzy wynikami uzyskanymi w teście a oceną inteligencji przez partnerów. Okazało się, że ludzie mają tendencję do znacznego przeszacowywania inteligencji swoich partnerów, nawet bardziej niż własnej inteligencji. Kobiety przeszacowywały inteligencję swoich partnerów aż o 38 punktów IQ, natomiast mężczyźni oceniali inteligencję swoich partnerek o 36 punktów IQ wyżej niż w rzeczywistości. Wyniki tego badania wskazują zatem, że w stosunku do bliskich nam osób stosujemy podobny mechanizm jak w odniesieniu do siebie. Mamy tendencję do zniekształcania wizerunku partnera/partnerki i postrzegania go/jej w nazbyt optymistyczny sposób.

Pomimo istnienia efektu nierealistycznego optymizmu w odniesieniu do inteligencji partnera/partnerki, ludzie są do pewnego stopnia w stanie trafnie oszacować inteligencję osób, z którymi tworza związek. Powstaje pytanie, czy jesteśmy w stanie oszacować inteligencję osoby, którą mniej znamy, a nawet osoby, którą widzimy po raz pierwszy w życiu. Na to pytanie próbowali odpowiedzieć Borkenau i Liebler (1993), którzy sprawdzali związek między tym, jak ludzie szacowali inteligencję nieznajomej osoby a rzeczywistym poziomem inteligencji tej osoby. Badacze poprosili grupę osób o nagranie krótkiego, trwającego $90 \mathrm{~s}$, filmu, na którym osoby te odczytywały tekst (prognozę pogody). Oprócz tego dokonano pomiaru ich inteligencji przy użyciu standardowego testu IQ. Następnie poproszono inną grupę, która nie miała żadnego kontaktu z uczestnikami pierwszej części badania, o oszacowanie inteligencji osób na podstawie filmów. Filmy przedstawiano w dwóch wersjach: bez dźwięku i z dźwiękiem. Wyniki badania ujawniły dość silny związek pomiędzy rzeczywistą inteligencją osób a ich inteligencją oszacowaną przez nieznajome im osoby (korelacja 0,43), jednakże efekt ten zachodził jedynie w przypadku filmu z dźwiękiem i zadaniami testu IQ mierzącymi inteligencję werbalną. Autorzy badania konkluduja, że jesteśmy w stanie oszacować do pewnego stopnia inteligencję osób na podstawie pierwszego wrażenia, ale przesłanki werbalne odgrywają w tym znacząca rolę. 


\section{JAK KSZTAŁTUJĄ SIĘ POTOCZNE KONCEPCJE INTELIGENCJI?}

Duża rozbieżność między subiektywnie szacowaną inteligencją a obiektywnymi wynikami testów IQ może sugerować, że potoczne rozumienie inteligencji odbiega od akademickiego ujęcia tego zjawiska. Badania prowadzone przez Sternberga Conway, Ketrona i Bernsteina (1981) wskazuja, że nie-psychologowie łączą z pojęciem inteligencji takie cechy jak bycie oczytanym, posiadanie otwartego umysłu czy umiejętność logicznego rozumowania, które w pewnym stopniu oddają akademickie rozumienie inteligencji. Jednakże, jak również zauważa Sternberg (1982), to, co badają psychologowie i to, co mierzą testy IQ, jedynie częściowo pokrywa się z tym, co o inteligencji myśli przeciętna osoba. Przykładowo w jednym z pierwszych badań jakie prowadzono w tym temacie Flugel (1947) zauważył, że ludzie często całkowicie utożsamiaja pojęcie inteligencji ogólnej z wiedzą lub mądrością, która podlega nieograniczonemu uczeniu się i może rozwijać się praktycznie przez całe życie, co jest niespójne z wynikami badań empirycznych (Flugel, 1947).

Interesująca koncepcję potocznego rozumienia inteligencji zaproponowała Carol Dweck $(1991,1999)$. Autorka uważa, że ludzie posiadają tzw. ukryte przekonania na temat inteligencji (Dweck, 1991). Zdaniem Dweck (1991), jedno z najważniejszych przekonań tego typu dotyczy możliwości zmiany poziomu inteligencji. Badaczka uważa, że niektórzy ludzie, implicite, zakładają, iż inteligencja jest czymś stałym i niezmiennym, natomiast inni są przekonani, że można ja zmieniać i rozwijać, zazwyczaj poprzez ciężka pracę. Pomimo tego, że posiadanie wymienionych przekonań nie koreluje z poziomem inteligencji, to Dweck (1999) zaobserwowała, iż osoby zakładające stałość inteligencji w sytuacji pogorszenia się ich osiagnięć życiowych reagują zazwyczaj bezradnościa, podczas gdy ci, którzy przekonani są o możliwości zmiany potencjału intelektualnego w tej samej sytuacji radzą sobie dobrze z trudnościami. Zdaniem Dweck (1999), ci ostatni starają się szukać powodów zaistniałych problemów, będąc przekonanym, że można je zmienić. Pierwsi zaś zakładaja, iż ich wysiłki nie wpłyną na zmianę sytuacji.

Co ciekawe, potoczne koncepcje inteligencji są kształtowane rozwojowo. U młodszych dzieci rozumienie inteligencji znaczaco odbiega od akademickiego ujęcia, jednakże wraz z wiekiem potoczne koncepcje inteligencji zbliżają się do naukowej wiedzy psychologicznej (Furnham, 2001). Przykładowo w jednym z badań najmłodsze dzieci (w wieku 6-9 lat) postrzegały inteligencję przez pryzmat subiektywnej trudności w rozwiązywaniu zadań (Nicholls, Patashnick, Mettetal, 1986). W starszej grupie, około 10. roku życia, pojęcie inteligencji wiązało się głównie z funkcjami pamięciowymi, podczas gdy w najstarszej ba- 
danej grupie (19-22 lata) koncepcja inteligencji była najbardziej dojrzała, bliska rozróżnieniu na inteligencję skrystalizowaną i płynną (Nicholls i in., 1986). W latach '80 XX w. przeprowadzono badanie pośród australijskich uczniów. Uwzględniono trzy grupy: uczniów szkół podstawowych (średnia wieku ok. 12 lat), uczniów szkół średnich (wiek ok. 15 lat) i studentów (średni wiek 18,6 lat; Chen, Holman, Francis-Jones, Burmester, 1988). Badani oceniali, na ile różne zadania poznawcze mierzą inteligencję. Wśród najmłodszych uczniów dominowało przekonanie, że zadania werbalne są kluczowe dla pomiaru IQ. W średniej grupie za najważniejsze wyznaczniki inteligencji uznawano zadania werbalne, pamięciowe i niewerbalne rozumowanie. Studenci jako najistotniejsze dla inteligencji postrzegali zdolności niewerbalne. Różnice rozwojowe w ujmowaniu inteligencji wydają się potwierdzać również badania Zajenkowskiego (2021), który zauważył, że wśród adolescentów (ok. 16. r.ż.), subiektywnie szacowana inteligencja w ogóle nie korelowała z wykonaniem standardowego testu IQ (testu Ravena). Z drugiej strony, subiektywna inteligencja wiazzała się mocno z innymi zmiennymi, takimi jak poziom narcyzmu czy satysfakcja z życia. Te wyniki sugeruja, że na badanym etapie rozwoju koncepcja inteligencji rozmija się z tym, co mierzą testy IQ, jednocześnie zaś bliska jest rozpowszechnionym społecznie przekonaniom, łączącym inteligencję z wysoka samooceną i większym zadowoleniem z życia.

\section{CO DETERMINUJE PRZEKONANIA NA TEMAT INTELIGENCJI?}

Jak wspomniano, związek między subiektywnie szacowaną inteligencją a wynikiem w obiektywnym teście IQ jest umiarkowany (korelacja ok. 0,30; Freund, Kasten, 2012), co oznacza, że to, co ludzie myślą o własnej inteligencji, jest determinowane również przez inne czynniki niż tylko rzeczywisty poziom inteligencji. Badania w tym zakresie wskazują na szczególne znaczenie takich czynników jak płeć, cechy osobowości i kultura.

Wiele badań oraz metaanaliz wskazuje na różnice międzypłciowe w zakresie subiektywnie szacowanej inteligencji: mężczyźni postrzegają się jako bardziej inteligentni niż kobiety (Szymanowicz, Furnham, 2011). Jest to szczególnie interesujące, biorąc pod uwagę fakt, że różnice między płciami w zakresie ogólnej inteligencji są w większości badań nieistotne (np. Johnson, Bouchard, 2007). Co ciekawe, różnice międzypłciowe obserwuje się nie tylko w odniesieniu do subiektywnie ocenianej własnej inteligencji, ale również wtedy, gdy osoba badana ma oszacować poziom IQ członków własnej rodziny. Okazuje się, że dziadkowie, ojcowie i bracia są postrzegani jako bardziej 
inteligentni niż babcie, matki i siostry (Furnham, Rawles, 1995). Zjawisko to określa się często jako efekt „męskiej arogancji, żeńskiej skromności” (male bubris, female humility; Furnham, 2000). Jako jedną z możliwych przyczyn powstawania tych różnic badacze wskazują odmienne sposoby wychowywania chłopców, zachęcanych do bycia śmiałymi, i dziewczynek, zachęcanych do bycia uległymi (Furnham, 2000). Badania pokazuja, że różnice między chłopcami a dziewczynkami mogą się kształtować na wczesnym etapie rozwoju. $\mathrm{Na}$ przykład Zajenkowski (2021) zauważył, że już w grupie nastolatków (ok. 16. roku życia) chłopcy oceniają swoją inteligencję jako wyższą niż dziewczynki. Rodzi się zatem pytanie o to, na jak wczesnym etapie rozwoju powstają omawiane różnice międzypłciowe. Jest to o tyle zasadne, że może prowadzić do stereotypów płciowych i mieć poważne konsekwencje społeczne takie jak np. ryzyko zagrożenia stereotypem, które opisane zostało poniżej.

Interesujących rezultatów dostarcza także analiza różnic międzypłciowych w zakresie subiektywnego szacowania bardziej szczegółowych zdolności. W niektórych badaniach pytano ludzi o ocenę nie tylko własnej ogólnej inteligencji, ale również o oszacowanie poziomu zdolności matematyczno-logicznych, przestrzennych czy werbalnych. Okazuje się, że mężczyźni postrzegaja się jako bardziej zdolni w zakresie pierwszych dwóch rodzajów inteligencji, natomiast w przypadku zdolności werbalnych nie ma różnic między płciami (Szymanowicz, Furnham, 2011). Te wyniki w pewnym stopniu koresponduja z badaniami wskazującymi na przewagę kobiet pod względem zdolności werbalnych (np. Johnson, Bouchard, 2007). Niektórzy badacze zwracają uwagę, że być może potoczna koncepcja inteligencji ogólnej jest bliższa zdolnościom matematyczno-logicznym, w których mężczyźni uzyskują wyższe wyniki obiektywnie, a nie werbalnym (wyższe obiektywne wyniki kobiet), i dlatego też mężczyźni są postrzegani jako ogólnie bardziej inteligentni.

Innym ważnym czynnikiem wpływającym na postrzeganie własnej inteligencji jest osobowość. Spośród cech wyróżnionych w modelu Wielkiej Piątki, czyli w najbardziej popularnym modelu osobowości, ekstrawersja, otwartość i sumienność korelują dodatnio, natomiast neurotyczność związana jest ujemnie z subiektywnie szacowaną inteligencją (Chamorro-Premuzic, Furnham, 2005, 2006a; Howard, Cogswell, 2018; Zajenkowski, Gignac, 2018). Warto dodać, że wszystkie zależności utrzymywały się, gdy w badaniach kontrolowano również poziom rzeczywistej inteligencji. Oznacza to, że osoby o wysokiej ekstrawersji, otwartości i sumienności mają tendencję do nazbyt pozytywnego spostrzegania własnej inteligencji, podczas gdy osoby wysoko neurotyczne widzą swoje zdolności w sposób nadmiernie pesymistyczny. 
Cechą która najsilniej wiąże się z przeszacowaniem własnej inteligencji, jest narcyzm (Howard, Cogswell, 2018). Badania pokazują, że narcyzm koreluje pozytywnie z subiektywną inteligencją znacznie mocniej niż inteligencja obiektywna, płeć czy jakiekolwiek inne cechy osobowości (Zajenkowski, Czarna, Szymaniak, Dufner, 2020). Narcyzm, zwłaszcza jego tzw. wielkościowa forma, przejawia się skupieniem na sobie, dużą śmiałością społeczną, roszczeniowością i egoizmem (Krizan, Herlache, 2018). Osoby narcystyczne pragną mieć poczucie kontroli, wpływu na innych i dużej sprawczości (Campbell, Foster, 2007). Zajenkowski i Dufner (2020) zasugerowali, że ponieważ inteligencja ma duże znaczenie dla życia codziennego, i ponieważ wysokie jej nasilenie jest pożądane społecznie, osoby narcystyczne widzą się jako bardzo inteligentne, co daje im poczucie sprawstwa i kontroli. Autorzy jako przykład zachowania narcystycznego przywołali wypowiedzi prezydenta USA Donalda Trumpa, który często lubi się przechwalać swoim wysokim poziomem inteligencji. W jednym z tweetów stwierdził, że jego IQ jest jednym z najwyższych, a inni są przegrani („Sorry losers and haters but my IQ is one of the highest'). Inne badania wykazaly, jak ważne dla osób narcystycznych jest poczucie posiadania wysokiej inteligencji. Okazało się bowiem, że poczucie zadowolenia z życia czy pozytywnych doświadczeń emocjonalnych znacząco zależy od wielkościowych przekonań na temat własnej inteligencji wśród osób o wysokim poziomie narcyzmu (Zajenkowski, Czarna, 2015; Zajenkowski i in., 2020).

Inne interesujące wyniki dotyczą bardziej specyficznych cech osobowości. W jednym z badań wykazano, że osoby preferujące wieczorny tryb życia, czyli charakteryzujące się tzw. wieczornym chronotypem, w przeciwieństwie do osób porannych, mają tendencję do przecenienia własnej inteligencji (Zajenkowski, Jankowski, Stolarski, 2019). Autorzy badania nawiązali do faktu, że osoby wieczorne muszą się częściej przystosowywać do społecznych wymogów, takich jak poranne godziny pracy czy szkoły. Tym samym wieczorne „sowy” mogą czuć, że odbiegają od reszty społeczeństwa i bardziej zmagać się z trudnościami dnia codziennego, w czym może im pomagać poczucie intelektualnej wyjątkowości.

Zajenkowski i Gignac (2018) zaobserwowali także, że osoby charakteryzujace się wysoką cechą gniewu (mające tendencję do wybuchania i złości) również przeszacowują własną inteligencję. Ten wynik wpisuje się z kolei w najnowsze badania nad gniewem, które wskazuja, że jest to wyjątkowa emocja. Gniew jest bowiem emocją negatywną, ale w odróżnieniu od innych negatywnych emocji, takich jak lęk czy smutek, łączy się z tzw. motywacją dążeniową (approach motivation), a co za tym idzie - również nadmiernym optymizmem co do wła- 
snej skuteczności i poczucia kontroli. Wysokie mniemanie na temat własnych zdolności, w tym inteligencji, może pozwalać osobom z wysoką cechą gniewu czuć się pewniej w stosunku do innych.

Czynnikiem kształtującym przekonania na temat inteligencji jest również kultura. Badania z tego zakresu dotyczyły najczęściej porównań międzykulturowych szacowanej inteligencji oraz tego, jak ludzie z różnych kultur rozumieją pojęcie inteligencji (Furnham, 2001). Większość badań porównujących odległe kulturowo kraje wykazała, że Amerykanie i Brytyjczycy, którzy w próbach byli reprezentowani w ogromnej większości przez osoby białe, szacowały swoją inteligencję wyżej niż mieszkańcy krajów Afrykańskich (np. Uganda) czy azjatyckich (np. Japonia, Singapur), w których próby były etnicznie homogeniczne (Furnham, Baguma, 1999; Furnham, Fong, Martin, 1999; Furnham, Hosoe, Tang, 2001). Badacze sugerują, że te wyniki mogą być związane z poziomem indywidualizmu lub kolektywizmu w danym kraju (von Stumm, Chamorro-Premuzic, Furnham, 2009). W krajach indywidualistycznych (takich jak USA czy Wielka Brytania) przywiązuje się większą wagę do indywidualnego rozwoju jednostki i jej potencjału. W tym kontekście inteligencja może mieć duże znaczenie dla osiagnięcia sukcesu. W krajach zorientowanych bardziej kolektywistycznie ( jak kraje azjatyckie czy afrykańskie) większe znaczenie ma wspólnota, a zatem inteligencja może być mniej ceniona.

Powyższa interpretacja wydaje się być w zgodzie z badaniami na temat odmiennego pojmowania natury inteligencji przez przedstawicieli odmiennych kultur. Na przykład Ruzgis i Grigorenko (1994) zauważyli, że w krajach afrykańskich pojęcie inteligencji łączy się często z umiejętnością harmonijnego życia z innymi ludźmi. Wober (1972) stwierdził rozbieżności z zachodnimi teoriami inteligencji, pokazując, że np. szybkość rozumowania nie była uważana za istotny aspekt zdolności intelektualnych w krajach wschodnioafrykańskich. Jak zauważają Sternberg i in. (1981), przedstawiciele innych kultur mogą być wręcz podejrzliwi w przypadku, kiedy pewne czynności są wykonywane zbyt szybko. W niektórych plemionach w Zimbabwe przez inteligencję rozumie się bowiem ostrożność i rozwagę (Dasen, 1984). Yang i Sternberg (1997) przyglądali się chińskim koncepcjom inteligencji. Autorzy zauważyli, że w tradycji konfucjańskiej podkreśla się znaczenie dla intelektu życzliwości i robienia tego, co słuszne. Jak zauważa Sternberg (2000), wśród kultur afrykańskich i azjatyckich z pojęciem inteligencji, dużo częściej niż w kulturach zachodnich, wiąże się aspekt społeczny i umiejętność bycia z innymi. Co ciekawe, we wspomnianych kulturach uważa się, że inteligentne zachowanie przejawia się większą rozwaga i wstrzemięźliwością w wypowiedziach, czy wręcz częstszym milczeniem, co 
w świecie zachodnim uznaje się za przejaw niskiego poziomu IQ (Sternberg, 2000). Koncepcje inteligencji mogą różnić się znacznie między krajami, ale również wśród mieszkańców jednej kultury. Zdaniem Sternberga (2000), ludzie moga postrzegać inteligencję poprzez pryzmat zdolności uważanych przez nich za istotne dla osiagnięcia sukcesu, który każdy definiuje w subiektywny sposób.

Powyższy przegląd badań wskazuje, że ludzie prezentujący odmienne charakterystyki będą inaczej postrzegali własne zdolności. Subiektywnie szacowana inteligencja tylko częściowo pokrywa się z obiektywną inteligencja, a co za tym idzie wiele czynników poza samym IQ, takich jak płeć, cechy osobowości czy kultura, wpływa na tendencję danej osoby do przeceniania lub niedowartościowywania własnych zdolności. Kolejne ważne pytanie dotyczy tego, jakie znaczenie dla codziennego życia ma subiektywna ocena zdolności.

\section{JAKIE ZNACZENIE MA POSTRZEGANIE WŁASNEJ INTELIGENCJ DLA CODZIENNEGO ŻYCIA?}

ZNACZENIE INTELIGENCJI DLA DOBROSTANU I OSIĄGNIĘĆ AKADEMICKICH. Ludzie, którzy postrzegają swoją inteligencję jako relatywnie wysoką w porównaniu do innych, są bardziej zadowoleni z życia, doświadczają bardziej pozytywnego nastroju (Zajenkowski, Czarna, 2015; Zajenkowski, Matthews, 2019) i mają wyższą samoocenę (Chamorro-Premuzic, Furnham, 2006a). Badacze zwracają uwagę, że relację między subiektywnie ocenianą inteligencją a pozytywnymi doświadczeniami emocjonalnymi można tłumaczyć dwojako (Howard, Cogswell, 2018). Po pierwsze, osoby, które uważają się za inteligentne, moga, przynajmniej częściowo, rzeczywiście posiadać wysoki poziom IQ, a to może być dla nich źródłem satysfakcji. Z drugiej strony, pozytywne emocje moga wpływać na postrzeganie siebie i podwyższać samoocenę w zakresie własnych zdolności (Bandura, 2001, 2011), inteligencja ogólna zaś może być wyrazem zglobalizowanej oceny własnych kompetencji (Howard, Cogswell, 2018).

Drugi obszar, w którym wysoko oceniana własna inteligencja ma duże pozytywne znaczenie, to osiągnięcia szkolne $\mathbf{i}$ akademickie. Okazuje się, że przekonania na temat własnych zdolności maja znaczenie już na wczesnych etapach edukacji. W jednym z badań Spinath, Spinath, Harlaar i Plomin (2006) przebadali dużą próbę 9-letnich uczniów. Dzieci wykonywały test inteligencji ogólnej oraz szacowały swoje umiejętności w zakresie kilku przedmiotów i aktywności szkolnych, np. czytania i pisania, wykonywania działań matematycz- 
nych, uczenia się na temat przyrody i działania świata fizycznego. Subiektywne przekonania uczniów na temat poziomu własnych zdolności były istotnie skorelowane z ich rzeczywistymi osiagnięciami (ocenami) szkolnymi. Szczególnie wysokie korelacje otrzymano w przypadku angielskiego i matematyki (ok. 0,40) a w zakresie przyrody związek był słabszy (ok. 0,11). Zwiazki te były niezależne od obiektywnie mierzonej inteligencji. W dalszych badaniach podłużnych badacze wykazali, że oszacowanie własnych umiejętności szkolnych w wieku lat 9 było istotnie skorelowane $\mathrm{z}$ rzeczywistymi osiagnięciami uczniów w wieku lat 12, znów niezależnie od inteligencji mierzonej testami (Chamorro-Premuzic, Harlaar, Greven, Plomin, 2010). Te wyniki pokazuja, jak duże znaczenie dla osiagnięć mają subiektywne przekonania na własny temat. Sama inteligencja okazała się silniej związana z osiagnięciami niż z postrzeganiem własnych umiejętności.

Subiektywna ocena własnej inteligencji wydaje się mieć niemniejsze znaczenie również na późniejszych etapach edukacji. Chamorro-Premuzic i Furnham (2006b) poprosili grupę brytyjskich studentów o oszacowanie własnej inteligencji oraz wykonanie testu IQ, a następnie sprawdzili, w jakim stopniu wyniki z obu miar inteligencji, tj. subiektywnej i obiektywnej, koreluja z ocenami z egzaminów uzyskanymi dwa lata później. Okazało się, że przekonania na temat poziomu własnej inteligencji znacząco przewidują oceny, nawet gdy wzięto pod uwagę obiektywną inteligencję studentów. Badacze zgodnie konkludują, że wysokie mniemanie na temat własnych zdolności intelektualnych daje ludziom poczucie pewności siebie, co przekłada się na osiagnięcia (Chamorro-Premuzic, Furnham, 2006b; Howard, Cogswell, 2018). W tym kontekście nawiązuje się często do koncepcji poczucia własnej skuteczności (selfefficacy) stworzonej przez Alberta Bandurę (1986). Poczucie to wpływa na nasze myśli i efektywność działań w codziennym życiu.

ZAGRAŻANIE INTELIGENCJA. Duże znaczenie inteligencji we współczesnym Świecie może mieć jednak również negatywne konsekwencje. Świadczą o tym badania, w których inteligencji używano w celu wzbudzenia poczucia zagrożenia u osób badanych. Jeden obszar takich dociekań skupia się na zagrażaniu ego danej osoby poprzez udzielenie negatywnej (zazwyczaj nieprawdziwej) informacji zwrotnej na temat poziomu jej inteligencji. Ogólnie u większości ludzi informacja, że w teście inteligencji wypadaja gorzej niż inni, obniża ich samopoczucie (Hart, Adams, Tortoriello, 2017; Maciantowicz, Zajenkowski, 2020; Rhodewalt, Morf, 1998; Stucke, Sporer, 2002). Jednakże procedury zagrażania ego stosowane są, zwłaszcza wobec osób, co do których wiadomo, 
że inteligencja może stanowić dla nich dużą wartość. Jak wspomniano wyżej, do tej grupy należą osoby o wysokim poziomie narcyzmu i rzeczywiście eksperymenty, w których próbowano wywołać reakcje emocjonalne u jednostek narcystycznych, często stosowały manipulację informacją zwrotną na temat poziomu IQ.

Jednym z przykładów może być tu badanie Rhodewalt i Morf (1998), w którym uczestnicy wypełniali kwestionariusz narcyzmu oraz standardowy test inteligencji stworzony przez Cattella i Cattell (1960). Następnie badani zostali poinformowani, że ich testy zostaną sprawdzone i będą mogli poznać swój wynik. W rzeczywistości osoby badane zostały losowo przypisane do jednego z dwóch warunków eksperymentalnych, w których manipulowano informacją zwrotną, tzn. przedstawiano nieprawdziwą informację o wyniku $\mathrm{w}$ teście inteligencji. Uczestnicy przypisani do pierwszej grupy otrzymali informację, że ich IQ plasuje się w 30 centylu, a zatem, że aż 70\% osób wypełnia test inteligencji lepiej od nich. Natomiast drugiej grupie mówiono, że ich IQ mieści się w 70 centylu, a zatem jedynie $30 \%$ osób osiągało wynik wyższy od nich. Jak się okazało, u badanych w grupie eksperymentalnej pogorszył się nastrój i ocena własnej skuteczności; dodatkowo osoby wysoko narcystyczne zareagowały na tę manipulację intensywniej, wykazując szczególną frustrację i gniew w odpowiedzi na negatywną informację zwrotną.

W ramach innego eksperymentu wzbudzano poczucie zagrożenia w stosunku do zdolności werbalnych uczestników badania (Bushman, Baumeister, 1998). Badani mieli za zadanie napisanie eseju. Następnie powiedziano im, że ich esej będzie oceniony przez innego uczestnika tego badania (który w rzeczywistości nie istniał). Osoby badane zostały losowo przypisane do jednego z dwóch warunków eksperymentalnych. W pierwszym - badani otrzymywali pozytywną informację zwrotna (np. „Nie mam uwag. Świetny esej!”) od nieprawdziwego uczestnika, zaś w drugim warunku otrzymywali negatywna informację („,To najgorszy esej, jaki kiedykolwiek przeczytałem”). Kolejna część procedury miała na celu sprawdzenie wystapienia reakcji agresywnych w każdym z warunków. Uczestnikom powiedziano, że i oni, i ich potencjalny partner (zmyślona osoba, która wcześniej oceniała ich esej) będą razem grali w grę komputerową, a ich zadanie będzie polegało na naciskaniu przycisku tak szybko, jak to możliwe w każdej próbie, z zaznaczeniem, że jeżeli naciśnie się przycisk za późno, w ramach kary usłyszy się w słuchawkach nieprzyjemny dźwięk (hałas). Każdy uczestnik mógł z góry ustawić intensywność hałasu, jaki słyszałby drugi uczestnik, jeżeli przegra. Możliwe było ustawienie różnych poziomów głośności: od 0 - brak szumu, 1 - szum na poziomie $60 \mathrm{~dB}$, 
aż do 10, czyli szumu na poziomie 105 dB. Wysoki poziom szumu łączył się z nieprzyjemnym odczuciem. Oprócz określenia intensywności hałasu uczestnik kontrolował również czas trwania hałasu. Trwał on tak długo, jak badany przytrzymywał wciśnięty przycisk. Zatem każdy mógł w pełni kontrolować wszystkie aspekty kary przegranego. Miarą zachowania agresywnego w tej sytuacji było ustawianie silniejszych i dłuższych sygnałów dźwiękowych dla partnera. Wyniki pokazały, że agresywne reakcje były częstsze u uczestników wcześniej skrytykowanych w ramach pracy nad esejem. Co więcej, zgodnie z przewidywaniami, najsilniejsze reakcje wykazały osoby o wysokim nasileniu narcyzmu. Takie osoby ustawiały poziomy hałasu i długość trwania kary na mocniejsze i dłuższe niż inni.

Wysoką wrażliwość osób narcystycznych na negatywne komunikaty związane z ich zdolnościami, i ogólnie inteligencją, zostały potwierdzone w kilku innych eksperymentach. Stucke i Sporer (2002) przeprowadzili badanie, w którym uczestnicy rozwiązywali test inteligencji zawierający zadania dotyczące rozumowania abstrakcyjnego oraz zdolności matematycznych i werbalnych. Uczestnikom, którzy zostali losowo przypisani do grupy zagrażania, mówiono, że ich wykonanie plasuje się w $20 \%$ najgorszych wyników wszystkich uczestników badania, natomiast uczestnicy w grupie kontrolnej otrzymywali komunikat, że są w lub 20\% najlepszych wyników. Po manipulacji eksperymentalnej badano nastrój i ogólną ocenę całego badania. Podobnie jak w innych badaniach osoby wysoko narcystyczne reagowały silniejszym gniewem oraz ogólnie gorzej oceniały sam eksperyment.

Wiele badań pokazuje również, że poczucie zagrożenia inteligencją można wywołać nie tylko u osób narcystycznych, które ogólnie wykazuja podwyższony i nierealistyczny obraz swoich zdolności, ale że pojęcie inteligencji może również piętnować ludzi poprzez odwołanie się do ich przynależności do określonej grupy. Zjawisko to, opisane po raz pierwszy przez Steela i Aronsona (1995), nazwano zagrożeniem stereotypem. W serii eksperymentów Steel i Aronson (1995) badali białych i czarnoskórych studentów. Celem badania było wzbudzenie stereotypu, wedle którego Afroamerykanie przejawiają niższe zdolności werbalne. Uczestników badania poproszono o wykonanie kilku trudnych zadań werbalnych zaczerpniętych z testu Graduate Examination Record, który jest wykorzystywany w rekrutacji na studia w wielu amerykańskich szkołach wyższych. Badanych losowo przydzielano do jednej z grup, w których udzielano odmiennej instrukcji. W jednym warunku, tzw. diagnostycznym, mówiono uczestnikom, że test mierzy zdolności werbalne i zdolność do rozumowania przy użyciu materiału językowego, i że test może pokazać mocne i słabe strony 
funkcjonowania intelektualnego danej osoby. W drugim warunku (nie-diagnostycznym) informowano, że to zadanie dotyczy rozwiązywania problemów, bez wskazywania na zaangażowanie zdolności werbalnych. Okazało się, zgodnie z przewidywaniem, że w warunku diagnostycznym, a więc w sytuacji, w której podkreślano charakter zdolności wymaganych w teście oraz ich znaczenie, osoby czarnoskóre wypadały gorzej niż osoby białe. Jednocześnie nie odnotowano różnic międzygrupowych w warunku nie-diagnostycznym, w którym nie eksponowano znaczenia zdolności werbalnych. Zdaniem autorów, świadczy to o tym, że aktywizacja negatywnego stereotypu (podkreślanie roli/zdolności) związanego z przynależnością do określonej grupy może być czynnikiem wpływającym na wykonanie zadania intelektualnego (Steel, Aronson, 1995). Tego typu rezultaty stwierdzono również w innych badaniach, przy użyciu innych testów, a nawet zaobserwowano zwiększone reakcje psychofizjologiczne związane ze stresem w odpowiedzi na zagrożenie stereotypem (zob. Steel, Spencer, Aronson, 2002).

Jak się okazuje, efekt zagrożenia stereotypem odnotowywano również w odniesieniu do innych niż rasowe grup. Wiele badań poświęcono temu, że kobiety rozwiązuja pewne zadania, na przykład logiczno-matematyczne, gorzej niż mężczyźni w sytuacji aktywizacji negatywnego stereotypu dotyczącego różnic międzypłciowych w zakresie zdolności matematycznych (Flore, Wicherts, 2015). W tego typu badaniach najczęściej wzbudza się stereotyp poprzez prezentację jednej grupie badanych tekstu, w którym pada stwierdzenie, że mężczyźni mają wyższe zdolności matematyczne niż kobiety. W grupie kontrolnej zaś nie mówi się o różnicach międzypłciowych. Następnie uczestnicy wykonuja zadania matematyczne. Wyniki wielu eksperymentów wskazują, że w sytuacji wzbudzenia negatywnego stereotypu płciowego kobiety wypadaja gorzej niż mężczyźni, natomiast przy braku aktywizacji stereotypu nie odnotowuje się różnic międzypłciowych (Pronin, Steele, Ross, 2004; Rędzio, 2020; Spencer, Steele, Quinn, 1999).

Zdaniem wielu badaczy, efekt zagrożenia stereotypem może tłumaczyć różnice w osiagnięciach szkolnych obserwowane pomiędzy osobami przynależącymi do odmiennych grup rasowych czy płciowych (Steel, Aronson, 1995). Być może stygmatyzacja brakiem uzdolnień w danym obszarze skutkuje również częstszą rezygnacją mniejszościowych grup etnicznych z kontynuowania edukacji lub rzadszym podejmowaniem określonych kierunków studiów przez kobiety (Rędzio, 2020). Jak się okazuje, negatywne działanie stereotypu płciowego obserwowane jest już w wieku szkolnym, co może przekładać się na dalsze etapy życia (Rędzio, 2020). 
Powyższe wyniki badań wskazują, że osoby narcystyczne są szczególnie wrażliwe na informacje dotyczące ich kompetencji. Negatywna ocena ich zdolności skutkuje nie tylko pogorszeniem nastroju, ale również wzrostem gniewu, czy wręcz pewnych zachowań agresywnych. Co ciekawe jednak, poczucie zagrożenia związane ze zdolnościami i inteligencją okazuje się być znacznie szerszym zjawiskiem. Odwołanie się do stereotypowych przekonań o niższych kompetencjach określonej grupy może wywołać lęk, gorsze wykonanie zadań intelektualnych, a nawet determinować życie jednostki poprzez wpływ na wybór ścieżki edukacyjnej i zawodowej. Te rezultaty wskazują na olbrzymie znaczenie pojęcia inteligencji we współczesnym świecie, jako, z jednej strony, źródła zadowolenia i poczucia pewności siebie, ale również szczególnie wrażliwego obszaru podatnego na zranienie.

\section{CZY MOŻNA ZMIENIĆ PRZEKONANIA NA TEMAT WŁASNEJ INTELIGENCJI?}

Subiektywna ocena własnej inteligencji może mieć doniosłe konsekwencje dla codziennego funkcjonowania ludzi, co pociaga za soba pytanie o możliwość wpływu i zmiany czyichś przekonań na temat własnych zdolności intelektualnych. Badania wskazują na znaczenie kilku czynników, które mogą modyfikować ocenę ludzi w tym zakresie i redukować nierealistyczny obraz siebie. Wśród najważniejszych z nich wymienia się ogólność ocenianej zdolności, stopień wiedzy na jej temat, oraz grupę, z którą się porównuje (Freund, Kasten, 2012; Zell, Krizan, 2014).

Jednym z ważnych czynników redukujących nierealistyczny obraz własnego intelektu jest poziom ogólności ocenianej zdolności (Ackerman, Beier, Bowen, 2002). Przykładowo pytanie o ogólny poziom inteligencji jest bardzo szerokie i może obejmować szereg różnych zachowań, funkcji i czynności. Tym samym pojęcie to może być interpretowane jako wieloznaczne, a osoba oceniająca siebie będzie miała trudności w precyzyjnym określeniu swojego poziomu tak ogólnej cechy. Z drugiej strony, pytanie o konkretne zdolności, np. pamięciowe, matematyczne czy werbalne wiąże się z bardziej specyficznymi czynnościami, które łatwiej nam ocenić. Każdy bowiem na co dzień zbiera doświadczenia dotyczące tego, jak szybko liczy, czy zapamiętuje przeczytane fakty z podręcznika. Wyniki badań potwierdzają to przypuszczenie - osoby badane są w stanie lepiej ocenić bardziej konkretne i specyficzne zdolności niż ogólniejsze, takie jak poziom inteligencji (Ackerman i in., 2002; Zell, Krizan, 2014). 
Inny ważny czynnik, który może wpływać na percepcję zdolności, wiąże się ze znajomością określonej zdolności. W procedurze badawczej ludzie mogą oceniać swoje zdolności przed wykonaniem obiektywnego testu inteligencji lub po nim (Zell, Krizan, 2014). Okazuje się, że silniejsze związki między subiektywną i obiektywną inteligencją uzyskuje się w tym drugim przypadku (Ackerman, Wolman, 2007). Badacze zwracają uwagę na to, że gdy ludzie oceniają swój poziom IQ przed testem, mogą nie wiedzieć, o jaki rodzaj zdolności chodzi. Jak wspominaliśmy wyżej, potoczne koncepcje inteligencji moga różnić się od akademickich (Sternberg i in., 1981), a co za tym idzie, ocena własnego intelektu może nie przystawać do tego, co mierza testy. W sytuacji gdy ludzie najpierw rozwiązują test inteligencji, otrzymuja poniekąd informację, co pod mianem inteligencji rozumieją psychologowie. Jednakże efekt oceny związany ze znajomościa testu może być ulotny. Interesujące badanie w tym temacie przeprowadzili Gold i Kuhn (2017), którzy prosili grupę licealistów o ocenę własnej inteligencji przed wykonaniem testu inteligencji, natychmiast po jego wykonaniu, a następnie tydzień i dwa tygodnie po pierwszym badaniu. Okazało się, że poziom subiektywnej oceny inteligencji zmniejszał się zaraz po wykonaniu testu IQ, jednakże w kolejnych pomiarach, tj. tydzień i dwa tygodnie później, subiektywna ocena wzrastała i wracała do punktu wyjścia. Wynik ten można zinterpretować w taki sposób, że bezpośredni kontakt z testem inteligencji może wpłynąć na percepcję zdolności i zredukować nazbyt optymistyczny obraz własnego intelektu. Jednakże efekt ten wydaje się być krótkotrwały, ponieważ ludzie mają tendencję do powrotu do nierealistycznych złudzeń.

Dla trafności oceny własnego intelektu znaczenie może mieć również grupa, z którą ludzie się porównują (Freund, Kasten, 2012). Wyniki badań wskazuja że kiedy pyta się badanych o ocenę własnej inteligencji (np. na skali od 1 do 10) bez wskazywania grupy odniesienia, korelacja z rzeczywistym poziomem IQ jest niższa niż w sytuacji, gdy uczestnicy badania mają się porównać z określona grupa ludzi, najlepiej dobrze sobie znana. Na przykład łatwiej jest porównać się z innymi studentami uniwersytetu, na którym się studiuje, niż ogólnie osobami w tym samym wieku.

\section{PODSUMOWANIE}

Przegląd badań na temat postrzegania własnej inteligencji pozwala na kilka ogólnych konkluzji. Po pierwsze, ludzie maja pewien wgląd we własne zdolności, jednakże ich subiektywna ocena inteligencji w dużym stopniu odbiega od rzeczywistego poziomu IQ. Najczęstsze zjawisko w tym zakresie wiąże się 
z przecenianiem własnej inteligencji i uleganiem tzw. efektowi ponadprzeciętności. Po drugie, podobnie bywa również z oceną inteligencji innych: potrafimy ocenić ją w pewnym stopniu nawet u nieznajomych, ale również przeceniamy jej poziom np. u partnerów/partnerek. Rozbieżność między potocznym rozumieniem inteligencji a koncepcjami akademickimi może być spora i kształtowana jest już na wczesnych etapach rozwoju, co najmniej od okresu dorastania. $\mathrm{Na}$ postrzeganie inteligencji ma wpływ również wiele czynników, takich jak płeć, cechy osobowości czy kontekst kulturowy. Wreszcie, przekonania na temat inteligencji mogą mieć ogromne znaczenie dla naszego samopoczucia oraz zachowania. Inteligencja może być, i bywa, używana do zagrażania poczucia czyjejś wartości, jak również dyskryminowania określonych grup społecznych. Jednakże najczęściej wskazuje się na pozytywne konsekwencje wysokiego mniemania na temat własnego intelektu, które łączy się z większym zadowoleniem z siebie i pozytywnymi emocjami. Nierealistyczne przekonania na temat własnej inteligencji można do pewnego stopnia zmodyfikować, choć efekt zmiany może być nietrwały. Większa znajomość siebie i bardziej realistyczne spostrzeganie własnych zdolności nie musi jednak wcale przynosić oczywistych korzyści. Niedawne badania pokazują, że bardziej adekwatne spostrzeganie własnej inteligencji, zarówno ogólnej, jak i emocjonalnej, nie przekładało się ani na większe zadowolenie z życia, ani na jakość relacji interpersonalnych (He, Côté, 2019). Z drugiej strony, pewien poziom nierealistycznego optymizmu w sferze spostrzegania własnego potencjału intelektualnego może być niezbędny dla zachowania pozytywnego samopoczucia (Dufner $\mathrm{i}$ in., 2012).

\section{BIBLIOGRAFIA}

Ackerman, P. L., Beier, M. E., Bowen, K. R. (2002). What we really know about our abilities and our knowledge. Personality and Individual Differences, 33, 587-605. https://doi.org/10.1016/S0191-8869(01)00174-X

Ackerman, P. L., Wolman, S. D. (2007). Determinants and validity of self-estimates of abilities and self-concept measures. Journal of Experimental Psychology: Applied, 13(2), 57-78. https://doi.org/10.1037/1076-898X.13.2.57

Alicke, M. D., Govorun, O. (2005). The better-than-average effect. W: M. D. Alicke, D. A. Dunning, J. I. Krueger (red.), Studies in self and identity. The self in social judgment (s. 85-106). Nowy Jork: Taylor \& Francis Group.

Bandura, A. (1986). Social foundations of thought and action: A social cognitive theory. Englewood Cliffs: Prentice-Hall Inc. 
Bandura, A. (2001). Social cognitive theory: An agentic perspective. Annual Review of Psychology, 52(1), 1-26. https://doi.org/10.1146/annurev.psych.52.1.1

Bandura, A. (2011). A social cognitive perspective on positive psychology. Revista de Psicología Social, 26(1), 7-20. https://doi.org/10.1174/021347411794078444

Borkenau, P., Liebler, A. (1993). Convergence of stranger ratings of personality and intelligence with self-ratings, partner ratings, and measured intelligence. Journal of Personality and Social Psychology, 65(3), 546-553. https://doi.org/10.1037/00223514.65.3.546

Bushman, B. J., Baumeister, R. F. (1998). Threatened egotism, narcissism, self-esteem, and direct and displaced aggression: Does self-love or self-hate lead to violence? Journal of Personality and Social Psychology, 75, 219-229. https://doi. org/10.1037/0022-3514.75.1.219

Buss, D. M., Abbott, M., Angleitner, A., Asherian, A., Biaggio, A., Blanco-Villasenor, A., ..., Ekehammar, B. (1990). International preferences in selecting mates: A study of 37 cultures. Journal of Cross-Cultural Psychology, 21(1), 5-47. https://doi. org/10.1177/0022022190211001

Campbell, W. K., Foster, J. D. (2007). The narcissistic self: Background, an extended agency model, and ongoing controversies. W: C. Sedikides, S. J. Spencer (red.), The self (s. 115-138). Nowy Jork: Psychology Press. https://doi. org/10.1177/0022022190211001

Cattell, R. B., Cattell, A. K. S. (1960). Measuring intelligence with the culture fair tests. Champaign: Institute for Personality and Ability Testing.

Chamorro-Premuzic, T., Furnham, A. (2005). Personality and intellectual competence. New Jersey: Lawrence Erlbaum Associates.

Chamorro-Premuzic, T., Furnham, A. (2006a). Intellectual competence and intelligent personality: A third way in differential psychology. Review of General Psychology, 10, 251-267. https://doi.org/10.1037/1089-2680.10.3.251

Chamorro-Premuzic, T., Furnham, A. (2006b). Self-assessed intelligence and academic performance. Educational Psychology, 26, 769-779. https://doi. org/10.1080/01443410500390921

Chamorro-Premuzic, T., Harlaar, N., Greven, C. U., Plomin, R. (2010). More than just IQ: A longitudinal examination of self-perceived abilities as predictors of academic performance in a large sample of UK twins. Intelligence, 38(4), 385-392. https://doi.org/10.1016/j.intell.2010.05.002

Chen, M., Holman, J., Francis-Jones, N., Burmester, L. (1988). Conceptions of intelligence of primary school, high school and college student. British Journal of Developmental Psychology, 6, 71-82. https://doi.org/10.1111/j.2044-835X.1988.tb01081.x 
Dasen, P. R. (1984). The cross-cultural study of intelligence: Piaget and the Baoule. International Journal of Psychology, 19(1-4), 407-434. https://doi. org/10.1080/00207598408247539

Dufner, M., Denissen, J. J. A., van Zalk, M., Matthes, B., Meeus, W. H. J., van Aken, M. A. G., Sedikides, C. (2012). Positive intelligence illusions: On the relation between intellectual self-enhancement and psychological adjustment. Journal of Personality, 80, 537-572. https://doi.org/10.1111/j.1467-6494.2011.00742.x

Dunning, D. (2005). Self-insight: Roadblocks and detours on the path to knowing thyself. Nowy Jork: Psychology Press.

Dweck, C. S. (1991). Self-theories and goals: Their role in motivation, personality and development. Nebraska Symposium on Motivation, 38, 199-235.

Dweck, C. S. (1999). Self-theories: Their role in motivation, personality and development. Nowy Jork: Psychology Press.

Ferris, D. L., Johnson, R. E., Sedikides, C. (2018). The Self at work: Fundamental theory and research. SIOP Organizational Frontiers Series. Nowy Jork: Routledge Press.

Flore, P. C., Wicherts, J. M. (2015). Does stereotype threat influence performance of girls in stereotyped domains? A meta-analysis. Journal of School Psychology, 53(1), 25-44. https://doi.org/10.1016/j.jsp.2014.10.002

Flugel, J. C. (1947). An inquiry as to popular views on intelligence and related topics. British Journal of Educational Psychology, 17, 140-152. https://doi. org/10.1111/j.2044-8279.1947.tb02222.x

Freund, P., Kasten, N. (2012). How smart do you think you are? A meta-analysis on the validity of self-estimates of cognitive ability. Psychological Bulletin, 138, 296-321. https://doi.org/10.1037/a0026556

Furnham, A. (2000). Thinking about intelligence. The Psychologist, 13(10), 510-514.

Furnham, A. (2001). Self-estimates of intelligence: Culture and gender difference in self and other estimates of both general $(g)$ and multiple intelligences. Personality and Individual Differences, 31, 1381-1405. https://doi.org/10.1016/S01918869(00)00232-4

Furnham, A., Baguma, P. (1999). Self-estimates of intelligence: A cross-cultural study from three continents. North American Journal of Psychology, 1, 69-78.

Furnham, A., Fong, G., Martin, N. (1999). Sex and cross-cultural differences in the estimated multifaceted intelligence quotient score for self, parents and siblings. Personality and Individual Differences, 26, 1025-1034. https:/ / doi.org/10.1016/S01918869(98)00201-3

Furnham, A., Hosoe, T., Tang, T. L.-P. (2001). Male hubris and female humility? Across-cultural study of ratings of self, parental and sibling multiple intelligence in 
America, Britain, and Japan. Intelligence, 30(1), 101-115. https://doi.org/10.1016/ S0160-2896(01)00080-0

Furnham, A., Rawles, R. (1995). Sex differences in the estimation of intelligence. Journal of Social Behavior and Personality, 10(3), 741-748.

Gignac, G. E., Zajenkowski, M. (2020). The Dunning-Kruger effect is (mostly) a statistical artefact: Valid approaches to testing the hypothesis with individual differences data. Intelligence, 80, 101449. https://doi.org/10.1016/j.intell.2020.101449

Gignac, G. E., Zajenkowski, M. (2019). People tend to overestimate their romantic partner's intelligence even more than their own. Intelligence, 73, 41-51. https://doi. org/10.1016/j.intell.2019.01.004

Gold, B., Kuhn, J. T. (2017). A longitudinal study on the stability of self-estimated intelligence and its relationship to personality traits. Personality and Individual Differences, 106, 292-297. https://doi.org/10.1016/j.paid.2016.10.052

Gottfredson, L. S. (2002). Gottfredson's theory of circumscription, compromise, and self-creation. W: D. Brown (red.), Career choice and development (s. 85-148). San Francisco: John Wiley \& Sons.

Hart, W., Adams, J. M., Tortoriello, G. (2017). Narcissistic responses to provocation: An examination of the rage and threatened-egotism accounts. Personality and Individual Differences, 106, 152-156. https://doi.org/10.1016/j.paid.2016.10.049

He, J. C., Côté, S. (2019). Self-insight into emotional and cognitive abilities is not related to higher adjustment. Nature Human Behavior, 3, 867-884. https://doi. org/10.1038/s41562-019-0644-0

Heck, P. R., Simons, D. J., Chabris, C. F. (2018). 65\% of Americans believe they are above average in intelligence: Results of two nationally representative surveys. PLoS One, 13(7), e0200103. https://doi.org/10.1371/journal.pone.0200103

Horward, M. C., Cogswell, J. (2018). The „other” relationships of self-assessed intelligence: A meta-analysis. Journal of Research in Personality, 77, 31-46. https://doi. org/10.1016/j.jpp.2018.09.006

Johnson, W., Bouchard, T. J., Jr. (2007). Sex differences in mental abilities: $g$ masks the dimensions on which they lie. Intelligence, 35(1), 23-39. https://doi.org/10.1016/j. intell.2006.03.012

Krizan, Z., Herlache, A. D. (2018). The narcissism spectrum model: A synthetic view of narcissistic personality. Personality and Social Psychology Review, 22(1), 3-31. https://doi.org/10.1177/1088868316685018

Maciantowicz, O., Zajenkowski, M. (2020). Emotional experiences in vulnerable and grandiose narcissism: Anger and mood in neutral and anger evoking situations. Self and Identity. Advance online publication. https://doi.org/10.1007/s12144-01900504-6 
Kruger, J., Dunning, D. (1999). Unskilled and unaware of it: How difficulties in recognizing one's own incompetence lead to inflated self-assessments. Journal of Personality and Social Psychology, 77(6), 1121-1134. https://doi.org/10.1037//00223514.77.6.1121.

Nicholls, J. G., Patashnick, M., Mettetal, G. (1986). Conceptions of ability and intelligence. Child Development, 57(3), 636-645. https://doi.org/10.2307/1130342

Pronin, E., Steele, C. M., Ross, R. (2004). Identity bifurcation in response to stereotype threat: Women and mathematics. Journal of Experimental Social Psychology, 40, 152-168. https://doi.org/10.1016/S0022-1031(03)00088-X

Rędzio, A. M. (2020). Paradoksalne reakcje na zagrożenie stereotypem: znaczenie (braku) bezradności intelektualnej. W: M. Kofta, A. M. Rędzio (red.), Poczucie kontroli i niepewnośc: Konsekwencje dla rozumienia świata spotecznego (s. 223-248). Warszawa: Liberi Libri.

Reilly, J., Mulhern, G. (1995). Gender differences in self-estimated IQ: The need for care in interpreting group data. Personality and Individual Differences, 18(2), 189-192. https://doi.org/10.1016/0191-8869(94)00148-L

Rhodewalt, F., Morf, C. C. (1998). On self-aggrandizement and anger: A temporal analysis of narcissism and affective reactions to success and failure. Journal of Personality and Social Psychology, 74, 672-685. https://doi.org/10.1037/00223514.74.3.672

Ruzgis, P., Grigorenko, E. L. (1994). Cultural meaning systems, intelligence, and personality. W: R. J. Sternberg, P. Ruzgis (red.), Personality and intelligence (s. 248-270). Nowy Jork: Cambridge University Press.

Spencer, S. J., Steele, C. M., Quinn, D. M. (1999). Stereotype threat and women's math performance. Journal of Experimental Social Psychology, 35, 4-28. https:/ /doi. org/10.1006/jesp.1998.1373

Spinath, B., Spinath, F. M., Harlaar, N., Plomin, R. (2006). Predicting school achievement from general cognitive ability, self-perceived ability, and intrinsic value. Intelligence, 34(4), 363-374. https://doi.org/10.1016/j.intell.2005.11.004

Steele, C. M., Aronson, J. (1995). Stereotype threat and the intellectual test performance of African American. Journal of Personality and Social Psychology, 69, 797-811. https://doi.org/10.1037/0022-3514.69.5.797

Steele, C. M., Spencer, S. J., Aronson, J. (2002). Contending with group image: The psychology of stereotype and social identity threat. W: M. P. Zanna (red.), Advances in experimental social psychology, t. 34 (s. 379-440). San Diego: Academic Press. https://doi.org/10.1016/s0065-2601(02)80009-0

Sternberg, R. J. (1982). Who’s intelligent? Psychology Today, 16, 30-39. 
Sternberg, R. J. (2000). The concept of intelligence. W: R. J. Sternberg (red.), Handbook of intelligence (s. 3-15). Nowy Jork: Cambridge University Press.

Sternberg, R. J., Conway, B. E., Ketron, J. L., Bernstein, M. (1981). People's conceptions of intelligence. Journal of Personality and Social Psychology, 41(1), 37-55. https:/ / doi.org/10.1037/0022-3514.41.1.37

Stucke, T. S., Sporer, S. L. (2002). When a grandiose self-image is threatened: Narcissism and self-concept clarity as predictors of negative emotions and aggression following ego-threat. Journal of Personality, 70(4), 509-532. https://doi. org/10.1111/1467-6494.05015

Szymanowicz, A., Furnham, A. (2011). Gender differences in self-estimates of general, mathematical, spatial and verbal intelligence: Four meta analyses. Learning and Individual Differences, 21, 493-504. https://doi.org/10.1080/00224545.2012.754397

Wober, M. (1972). Culture and the concept of intelligence: A case in Uganda. Journal of Cross-Cultural Psychology, 3(3), 327-328. https://doi.org/10.1177/002202217200300312

Von Stumm, S., Chamorro-Premuzic, T., Furnham, A. (2009). Decomposing self-estimates of intelligence: Structure and sex differences across 12 nations. British Journal of Psychology, 100(2), 429-442. https://doi.org/10.1348/000712608X357876

Yang, S. Y., Sternberg, R. J. (1997). Taiwanese Chinese people's conceptions of intelligence. Intelligence, 25(1), 21-36. https:/ / doi.org/10.1016/S0160-2896(97)90005-2

Zajenkowski, M. (2021). How do teenagers perceive their intelligence? Narcissism, intellect, well-being and gender as correlates of self-assessed intelligence among adolescents. Personality and Individual Differences, 169, 109978. https://doi. org/10.1016/j.paid.2020.109978

Zajenkowski, M., Czarna, A. (2015). What makes narcissists unhappy? Subjectively assessed intelligence moderates the relationship between narcissism and psychological well-being. Personality and Individual Differences, 77, 50-54. https://doi. org/10.1016/j.paid.2014.12.045

Zajenkowski, M., Czarna, A. Z., Szymaniak, K., Dufner, M. (2020). What do highly narcissistic people think and feel about (their) intelligence? Journal of Personality, 88(4), 703-718. https://doi.org/10.1111/jopy.12520

Zajenkowski, M., Dufner, M. (2020). Why do narcissists care so much about intelligence? Current Directions in Psychological Science, 29(3), 261-266. https://doi. org/10.1177/0963721420917152

Zajenkowski, M., Gignac, G. E. (2018). Why do angry people overestimate their intelligence? Neuroticism as a suppressor of the association between Trait-Anger and subjectively assessed intelligence. Intelligence, 70, 12-21. https://doi.org/10.1016/j. intell.2018.11.005 
Zajenkowski, M., Jankowski, K. S., Stolarski, M. (2019). Why do evening people consider themselves more intelligent than morning individuals? The role of big five, narcissism, and objective cognitive ability. Chronobiology International, 36(12), 1741-1751. https://doi.org/10.1080/07420528.2019.1680559

Zajenkowski, M., Matthews, G. (2019). Intellect and openness differentially predict affect: Perceived and objective cognitive ability contexts. Personality and Individual Differences, 137, 1-8. https://doi.org/10.1016/j.paid.2018.08.001

Zajenkowski, M., Stolarski, M., Maciantowicz, O., Malesza, M., Witowska, J. (2016). Time to be smart: Uncovering a complex interplay between intelligence and time perspectives. Intelligence, 58, 1-9. https://doi.org/10.1016/j.intell.2016.06.002

Zell, E., Krizan, Z. (2014). Do people have insight into their abilities? A metasynthesis. Perspectives on Psychological Science, 9(2), 111-125. https://doi.org/10. $1177 / 1745691613518075$

Zell, E., Strickhouser, J. E., Sedikides, C., Alicke, M. D. (2020). The better-than-average effect in comparative self-evaluation: A comprehensive review and meta-analysis. Psychological Bulletin, 146(2), 118-149. https://doi.org/10.1037/bul0000218 

"Nie taki diabeł straszny..."

- czyli poznawcze

konsekwencje gniewu i ich

motywacyjne podłoże

Kinga Szymaniak (iD https://orcid.org/0000-0001-5887-9028

Uniwersytet Warszawski, Wydział Psychologii

kinga.szymaniak@psych.uw.edu.pl 
„Czasami, gdy człowiek doświadcza gniewu, wszystko wydaje się oczywiste i proste. Gniew zaprowadza porządek, pokazuje świat w oczywistym skrócie, w gniewie powraca też dar jasności widzenia, o który trudno w innych stanach"

Tokarczuk (2017, s. 43)

\section{KILKA SŁÓW O GNIEWIE I JEGO HISTORII}

Wszyscy znamy gniew z życia codziennego bez względu na to, w jakim wieku jesteśmy i w jakiej kulturze żyjemy. Ekspresję gniewu możemy zaobserwować już u dwumiesięcznych niemowląt (Lewis, Alessandri, Sullivan, 1990). Według badań prowadzonych na przestrzeni kilku dekad, gniew jest jedną z najczęściej doświadczanych oraz najłatwiej rozpoznawalnych przez nas emocji (np. Lerner, Gonzalez, Small, Fischhoff, 2003; Scherer, Tannenbaum, 1986; Scherer, Wallbott, 1994; Shaver, Schwartz, Kirson, O’Connor, 1987). Twarze wyrażające gniew identyfikujemy szybciej i bardziej precyzyjnie niż w przypadku innych stanów afektywnych (Hansen, Hansen, 1988). W latach ' 80 przeciętny obywatel Stanów Zjednoczonych odczuwał gniew co najmniej kilka razy na tydzień (Averill, 1983). Według nowszych danych opublikowanych przez Organizacje Zdrowia Psychicznego w Wielkiej Brytanii (Mental Health Organization; Richardson, Halliwell, 2008) coraz częściej się denerwujemy, a ekspresja gniewu znacznie łatwiej wymyka się nam spod kontroli.

Gniew definiowany jest jako emocjonalny komponent agresji i należy odróżnić go od wrogości i przemocy (werbalnej i fizycznej), stanowiących odpowiednio jej poznawczy i behawioralny wymiar (Buss, Perry, 1992). Rola gniewnych odczuć została dostrzeżona już w czasach starożytnych. Wtedy to gniew utożsamiany był z dającym nadludzkie moce atrybutem duchów, demonów i bóstw. Powodem gniewu bogów był najczęściej brak lojalności i nieposłuszeństwo ludzi (zob. Potegal, Novaco, 2010). Z kolei wśród ludzi, boski gniew siał nieopisany postrach i grozę (np. Lai, 1990; Leslie, 1998). Jednak wraz z rozwojem greckiej i rzymskiej filozofii popularny w wielu wierzeniach 
obraz gniewu jako zarezerwowanego wyłącznie dla nadprzyrodzonych istot został wyparty przez gniew „dostępny” także dla zwykłych śmiertelników (np. zob. Allen, 2003; Harris, 2001). Przykładowo według Greków gniew był jedną z pierwszych emocji odczuwanych przez noworodki (zob. Hanson, 2003; Sullivan, Lewis, 2010). Galen, jeden z najznamienitszych starożytnych lekarzy, ostrzegał jednak, że częsta ekspresja gniewu u niemowląt jest wyraźnym predyktorem poważnych chorób somatycznych w wieku dorosłym. Podkreślić należy, że gniew postrzegano nie tylko jako stan mający negatywne konsekwencje dla zdrowia fizycznego. Przypisywano mu także właściwości upośledzające racjonalne myślenie i zdrowy osąd (Potegal, Novaco, 2010). Seneka (45/1889) w swoim dziele De Ira (O gniewie) nie tylko definiuje, czym jest gniew, ale także oferuje wskazówki dotyczące zapobiegania odczuwania gniewu oraz opisuje trening samokontroli gniewnych odczuć. Co ciekawe, ta praca uważana jest za jedna z pierwszych traktujących o samoregulacji gniewu i oferujących wskazówki terapeutyczne (np. Kaufman, 2014). Przedstawianie gniewu jako emocji odbierającej nam możliwość racjonalnego myślenia znajdziemy także w Obronie Sokratesa, w której to jego wybitny uczeń Platon raportuje, jak mistrz, stojąc w obliczu kary śmierci, błaga, by nie decydować o jego losie w gniewie (Brickhouse, Smith, 2015).

Obecnie powszechny obraz gniewu niewiele odbiega od jego prototypowego ujęcia jako emocji niepożądanej, a wręcz szkodliwej dla naszego dobrostanu psychicznego (np. Diong, Bishop, 1999; Johnson, 1990; Siewert, Kubiak, Jonas, Weber, 2011). Co warto podkreślić, współcześnie przedmiotem badań jest gniew rozpatrywany zarówno w kategoriach chwilowego stanu emocjonalnego, jak i cechy, czyli tendencji do częstego i intensywnego odczuwania gniewu (np. Deffenbacher, 1992; Spielberger, 1999). Wysoka cecha gniewu sprzyja rozwojowi chorób serca (Siegman, Smith, 1994; Spielberger, 1988), zachowaniom agresywnym (Hortensius, Schutter, Harmon-Jones, 2011), nadmiernemu spożywaniu alkoholu (np. Liebsohn, Oetting, Deffenbacher, 1994) czy trudnościom w związkach romantycznych (Baron i in., 2007). W kontekście społecznym częste doświadczanie gniewu obniża poziom wzajemnego zaufania (Dunn, Schweitzer, 2005) i utrudnia współpracę (Van Kleef, De Dreu, Manstead, 2004). Osoby przejawiające silną tendencję do odczuwania tej emocji deklarują większą skłonność do przeżywania negatywnych emocji, angażowania się w słowne lub fizyczne potyczki czy do trudności na tle zawodowym, a nawet prawnym (Deffenbacher, Oetting, Lynch, Morris, 1996). Jednocześnie coraz większa liczba badań pokazuje, że gniew może wpływać na nasze funkcjonowanie podobnie do emocji o znaku pozytywnym, których 
odczuwanie jest dla nas przyjemne (np. Carver, Harmon-Jones, 2009; Ford $\mathrm{i}$ in., 2010; Ford, Tamir, Gagnon, Taylor, Brunyé, 2012). Taki „pozytywny” efekt gniewu uwidacznia się szczególnie na wymiarze poznawczym.

Niniejszy rozdział stanowi przegląd badań opublikowanych na przestrzeni dwóch ostatnich dekad, poświęconych wybranym konsekwencjom poznawczym gniewu zarówno jako stanu, jak i cechy. Celem przytoczonych wyników jest nie tylko pokazanie odmiennej od powszechnie znanej strony gniewu, ale także wskazanie konkretnych charakterystyk determinujących jego kognitywne następstwa. $\mathrm{Na}$ koniec przedstawione zostana praktyczne implikacje dotyczące zastosowania wiedzy na temat relacji gniew-poznanie w codziennym życiu.

\section{GNIEW JAKO EMOCJA: UJĘCIE WSPÓŁCZESNE}

Współczesne teorie emocji klasyfikuja gniew jako emocję podstawowa (Ekman, 1992; Plutchik, 1980), która pojawia się w odpowiedzi na sygnały prowokacji, zniewagi, niesprawiedliwego traktowania czy też wystąpienia przeszkody na drodze do wyznaczonego celu (Berkowitz, 1993; Depue, Zald, 1993; Lewis i in., 1990). Obecnie coraz więcej badaczy rozumie pojęcie emocji jako złożony z wielu komponentów konstrukt (Izard, 2010). Do kluczowych aspektów emocji najczęściej zalicza się walencję (znak pozytywny lub negatywny) i ocenę poznawcza, a ostatnio coraz częściej mówi się o wyzwalanej przez emocję motywacji (Gable, Poole, Harmon-Jones, 2015). Warto zaznaczyć, że badania dotyczące poznawczych konsekwencji emocji przez wiele lat rozpatrywały walencję (pozytywną lub negatywna) jako główny czynnik determinujący nasze funkcjonowanie poznawcze (np. Fredrickson, 1998, 2001). Emocje o walencji pozytywnej były łączone z motywacją dążeniową (approach motivation), zaś emocje o walencji negatywnej - z motywacją unikająca (avoidance motivation; np. Cacioppo, Gardner, Berntson, 1999; Lang, 1995). Innymi słowy, rola motywacji, jako niezależnego czynnika, była ignorowana w kontekście funkcjonowania poznawczego. W świetle ostatnich badań powyższe podejście wydaje się być jednak nadmiernym uproszczeniem. Dobrym przykładem emocji, która wymyka się przytoczonym sztywnym kategoryzacjom, jest właśnie gniew. Łączy on w sobie bowiem dwie (pozornie sprzeczne) charakterystyki: negatywną walencję i wysoką motywację dążeniową (Carver, Harmon-Jones, 2009; Harmon-Jones, Allen, 1998; Harmon-Jones, Harmon-Jones, Abramson, Peterson, 2009). Walencja odzwierciedla stopień, w jakim przeżywanie danej emocji jest dla jednostki przyjemne lub nieprzyjemne. Emocje, których odczuwanie jest przyjemne (np. radość, pożądanie) łączone są z pozytywną walencją, 
zaś emocje odczuwane jako nieprzyjemne (np. strach, smutek) kategoryzowane sa jako negatywne. Motywacja towarzysząca danej emocji definiowana jest jako siła dążenia w kierunku „do” lub „od” konkretnego bodźca (Harmon-Jones, Harmon-Jones, Price, 2013). Motywacja drążeniowa (approach) związana jest ze wzbudzeniem behawioralnego układu aktywacyjnego (behavioral activation system, BAS), który odpowiada za zachowania wzmacniane pozytywnie, ukierunkowane na osiagnięcie celu (Carver, Harmon-Jones, 2009). Motywacja unikająca (avoidance) towarzyszy uaktywnieniu awersyjnego systemu behawioralnego (behavioral inhibition system, BIS), którego działanie wyzwalane jest przez sygnały wskazujące na zagrożenie, ewentualną karę czy brak możliwości uzyskania nagrody (np. Watson, Wiese, Vaidya, Tellegen, 1999). Warto podkreślić, że motywacja towarzysząca danej emocji często mylnie utożsamiana jest z pobudzeniem (arousal; Gable, Harmon-Jones, 2013). Jak zauważają Gable i Harmon-Jones (2013), intensywność motywacji (czy też impuls do działania) mogą bezpośrednio łączyć się z pobudzeniem, ale pobudzenie, w odróżnieniu od motywacji, odnosi się wyłącznie do stanu fizjologicznego jednostki i nie zawsze musi prowadzić do podjęcia przez nią jakiejkolwiek aktywności (Gable, Harmon-Jones, 2013; Harmon-Jones, Gable, Price, 2013). Rosnąca liczba badań dowodzi, że to właśnie komponent motywacyjny, a nie negatywna walencja, odpowiada za poznawcze następstwa stanu i cechy gniewu (np. Carver, Harmon-Jones, 2009; Lerner, Keltner, 2001; Maglio, Gollwitzer, Oettingen, 2004; Threadgill, Gable, 2019).

Dążeniowy charakter gniewu przejawia się w chęci konfrontacji z przedmiotem/osobą, który/a ten gniew wywołał(a). Wzbudza pragnienie jawnego wyrażania swojej frustracji, co może prowadzić do wszczęcia kłótni lub nawet bójki (Harmon-Jones, 2003). Dążeniowy kierunek motywacji jest także tym, co łączy gniew z pozytywnym afektem. W literaturze psychologicznej trudno jest znaleźć przykład emocji pozytywnej o motywacji unikającej. Dodać należy, że powiązanie gniewu z dążeniowym kierunkiem motywacji potwierdzone zostało także na gruncie biologicznym, a dokładniej w badaniach nad asymetria czołową (Harmon-Jones, Allen, 1998; Harmon-Jones, 2003). Wcześniej zakładano, że przednia część lewej półkuli mózgu zaangażowana jest w ekspresję i doświadczanie pozytywnych emocji o motywacji dążeniowej, podczas gdy przedni obszar prawej półkuli łączony był z emocjami o negatywnej walencji i motywacji unikającej (np. Silberman, Weingartner, 1986). Co zaskakujące, Harmon-Jones i Allen (1998) wykazali, wbrew wieloletnim założeniom, że cecha gniewu wiąże się z wyższą aktywnością lewej, a nie prawej półkuli mózgu, podobnie do innych pozytywnych emocji. Warto podkreślić, że identycz- 
ne zależności zaobserwowano w odniesieniu do gniewu jako stanu (np. Harmon-Jones, Sigelman, 2001; Harmon-Jones, Sigelman, Bohlig, Harmon-Jones, 2003). Badania nad gniewem służą więc wyjaśnieniu, który z aspektów emocji, walencja czy motywacja, determinuje wydawane przez nas sądy i podejmowane decyzje.

\section{POZNAWCZE KONSEKWENCJE GNIEWU}

Gniew, jak każda z emocji dyskretnych, wyzwala określony schemat poznawczy (Lerner, Keltner, 2001; Smith, Ellsworth, 1985). Według założeń modelu tendencyjności oceny (appraisal tendency framework) ów specyficzny schemat określa znaczenie, jakie osoba nadaje danej sytuacji (Lerner, Keltner, 2001). Przykładowo radość wyzwala umiarkowane poczucie odpowiedzialności, duma łączy się z umiarkowanym poczuciem pewności i niskim poczuciem odpowiedzialności, zaś strach obniża poczucie pewności oraz wzmaga kontrolę sytuacyjna (Smith, Ellsworth, 1985). W przypadku gniewu centralnym komponentem oceny poznawczej jest poczucie kontroli i pewności (Lerner, Keltner, 2000, 2001). Poczucie pewności określa poziom szacowanej przewidywalności i zrozumiałości przyszłych zdarzeń. Z kolei poczucie kontroli to stopień, w jakim uważamy, że możemy wpłynąć na ich przebieg (Lerner, Keltner, 2001). Taki schemat poznawczy uwidacznia się w postaci konkretnych następstw gniewu powiązanych z dążeniowym kierunkiem motywacji.

Zestawienie takich konsekwencji, wraz z uwzględnieniem efektów innych emocji, przedstawia tabela 1. 
Tabela 1. Porównanie wybranych poznawczych konsekwencji gniewu i innych emocji o odmiennej walencji, kierunku i/lub intensywności motywacji

\begin{tabular}{|c|c|c|c|}
\hline Badanie & $\begin{array}{l}\text { Konsekwencja } \\
\text { poznawcza } \\
\text { gniewu }\end{array}$ & $\begin{array}{l}\text { Sprzyjający } \\
\text { stan } \\
\text { emocjonalny }\end{array}$ & $\begin{array}{c}\text { Niesprzyjający stan } \\
\text { emocjonalny }\end{array}$ \\
\hline Ford i in., 2012 & $\begin{array}{l}\text { Tendencja wzrokowa } \\
\text { w kierunku nagrody }\end{array}$ & $\begin{array}{l}\text { Ekscytacja } \\
\text { - pozytywna walencja } \\
\text { - wysoka dążeniowa } \\
\text { motywacja }\end{array}$ & $\begin{array}{l}\text { Strach } \\
\text { - negatywna walencja } \\
\text { - wysoka unikająca } \\
\text { motywacja }\end{array}$ \\
\hline He i in., 2013 & $\begin{array}{l}\text { Skupianie uwagi na } \\
\text { sygnałach nagrody, } \\
\text { a odwracanie uwagi od } \\
\text { sygnałów kary }\end{array}$ & $\begin{array}{l}\text { Radość } \\
\text { - pozytywna walencja } \\
\text { - niska dążeniowa mo- } \\
\text { tywacja }\end{array}$ & $\begin{array}{l}\text { Strach } \\
\text { - negatywna walencja } \\
\text { - wysoka unikająca } \\
\text { motywacja }\end{array}$ \\
\hline $\begin{array}{l}\text { Lerner i in., } \\
2003\end{array}$ & $\begin{array}{l}\text { Optymistyczna ocena } \\
\text { wystąpienia ataku terro- } \\
\text { rystycznego }\end{array}$ & $\begin{array}{l}\text { Radość } \\
\text { - pozytywna walencja } \\
\text { - niska dążeniowa mo- } \\
\text { tywacja }\end{array}$ & $\begin{array}{l}\text { Strach } \\
\text { - negatywna walencja } \\
\text { - wysoka unikająca } \\
\text { motywacja }\end{array}$ \\
\hline $\begin{array}{l}\text { Lerner, Kelt- } \\
\text { ner, } 2001\end{array}$ & $\begin{array}{l}\text { Optymistyczna ocena } \\
\text { własnej przyszłości }\end{array}$ & $\begin{array}{l}\text { Radość } \\
\text { - pozytywna walencja } \\
\text { - niska dążeniowa mo- } \\
\text { tywacja }\end{array}$ & $\begin{array}{l}\text { Strach } \\
\text { - negatywna walencja } \\
\text { - wysoka unikająca } \\
\text { motywacja }\end{array}$ \\
\hline $\begin{array}{l}\text { Lerner, Kelt- } \\
\text { ner, } 2001\end{array}$ & $\begin{array}{l}\text { Preferencja ryzykownej } \\
\text { metody w walce ze } \\
\text { śmiertelną chorobą }\end{array}$ & $\begin{array}{l}\text { Radość } \\
\text { - pozytywna walencja } \\
\text { - niska dążeniowa mo- } \\
\text { tywacja }\end{array}$ & $\begin{array}{l}\text { Strach } \\
\text { - negatywna walencja } \\
\text { - wysoka unikająca } \\
\text { motywacja }\end{array}$ \\
\hline $\begin{array}{l}\text { Maglio i in., } \\
2004\end{array}$ & $\begin{array}{l}\text { Większa liczba planów } \\
\text { oraz wyższa efektyw- } \\
\text { ność ich realizacji }\end{array}$ & - & $\begin{array}{l}\text { Smutek } \\
\text { - negatywna walencja } \\
\text { - niska unikająca moty- } \\
\text { wacja }\end{array}$ \\
\hline $\begin{array}{l}\text { Threadgill, } \\
\text { Gable, } 2018\end{array}$ & $\begin{array}{l}\text { Zawężanie zakresu } \\
\text { pamięci }\end{array}$ & $\begin{array}{l}\text { Przerażenie } \\
\text { - negatywna walencja } \\
\text { - wysoka motywacja } \\
\text { dążeniowa }\end{array}$ & $\begin{array}{l}\text { Smutek } \\
\text { - negatywna walencja } \\
\text { - niska motywacja dąże- } \\
\text { niowa }\end{array}$ \\
\hline
\end{tabular}

\section{GNIEW A OPTYMISTYCZNE SĄDY I PREFERENCJA RYZYKA}

Pierwszym przykładem takiej konsekwencji jest skłonność do wydawania optymistycznych sądów. Sądy te mogą dotyczyć zarówno własnych zdolności, jak i przebiegu sytuacji, w której uczestniczymy (np. Fischhoff, Gon- 
zalez, Lerner, Small, 2005; Lerner, Keltner, 2000, 2001; Zajenkowski, Gignac, 2018). Precyzując, Lerner i Keltner (2001) w jednym ze swoich badań dowiedli, że osoby z wysokim nasileniem gniewu jako cechy przejawiają skłonność do postrzegania własnej przyszłości w bardziej przyjaznych barwach niż losów czekających osoby będące w podobnym wieku, tej samej płci i na tym samym etapie edukacji (Lerner, Keltner, 2001). Mianowicie badacze poprosili studentów jednej z amerykańskich uczelni o oszacowanie prawdopodobieństwa wystąpienia pozytywnych i negatywnych zdarzeń w ich życiu. Zdarzenia te dotyczyły zarówno aspektów prywatnych (np. „Zachoruję na chorobę przenoszoną droga płciową”, jak i zawodowych (np. „Moja praca zostanie nagrodzona”). Co istotne, w tym badaniu, oprócz gniewu, uwzględniono także radość i strach. Radość, podobnie jak gniew, łączy się z motywacją dążeniowa. Z kolei strach charakteryzuje motywacja unikająca (Lerner, Keltner, 2001). Zgodnie z oczekiwaniami badaczy, osoby z wysoką cechą gniewu oceniały przyszłość optymistycznie. Konkretnie, zakładały one, że ich życie obfitować będzie w wydarzenia pozytywne. Podobne oceny wydawali uczestnicy z wysoką tendencją do odczuwania radości, natomiast odmienne - osoby z wysoką skłonnościa do przeżywania strachu, które postrzegały swoją przyszłość w zdecydowanie ciemniejszych barwach.

Optymistyczna postawa wśród osób doświadczających gniewu zaobserwowana została także w ocenie potencjalnego ryzyka (Lerner i in., 2003; Lerner, Keltner, 2000, 2001). W eksperymencie przeprowadzonym w Stanach Zjednoczonych niedługo po tragicznym zamachu na World Trade Center z 11 września 2001 r. zbadano wpływ gniewu, smutku i strachu na ocenę prawdopodobieństwa zaistnienia niebezpiecznych zdarzeń w kraju (Lerner i in., 2003). Badanie składało się z dwóch etapów. W pierwszym z nich mierzono poziom różnych emocji tuż po zamachu. Celem drugiego etapu było sprawdzenie, jak indukcja gniewu i strachu wpłynie na postrzegane ryzyko w kilka tygodni po wydarzeniu. Uczestnicy oceniali potencjalne ryzyko na trzech płaszczyznach: (1) ryzyko wydarzeń tragicznych w Stanach Zjednoczonych, (2) prawdopodobieństwo wydarzeń ryzykownych w życiu jednostki i podejmowane przez nią działania zapobiegawcze w nadchodzącym roku, (3) prawdopodobieństwo wydarzeń ryzykownych w życiu przeciętnego Amerykanina i podejmowane przez niego działania zapobiegawcze w nadchodzącym roku. Wyniki wykazały, że emocje odczuwane tuż po zamachu przewidywały oszacowania ryzyka dokonywane w 6 do 10 tygodni później. Ponadto, zgodnie z przewidywaniami, gniew wzbudzal najbardziej optymistyczne oceny w każdym aspekcie. Co warto zaznaczyć, podobnie jak w innych pracach (np. Lerner, Keltner, 2000, 
2001), efekt strachu był przeciwny do efektu gniewu: strach sprzyjał pesymistycznej ocenie ryzyka. Jak trafnie zauważają Litvak, Lerner, Tiedens, Shonk (2010), zależność ta została odnotowana z użyciem różnorodnych metod stosowanych w badaniach poświęconych zachowaniom ryzykownym, takich jak przywoływanie rzeczywistych historii z życia badanych czy prezentacja filmów pokazujących ryzykowne sytuacje (Fischhoff i in., 2005; Lerner i in., 2003; Lerner, Keltner, 2000).

\section{OSOBY Z WYSOKIM GNIEWEM PRZESZACOWUJĄ SWOJĄ INTELIGENCJĘ}

Nierealistyczny optymizm osób z wysokim nasileniem cechy gniewu przejawia się również w przeszacowywaniu poziomu własnych zdolności poznawczych. Zajenkowski i Gignac (2018) wykazali, że jednostki z wysokim poziomem cechy gniewu oszacowuja poziom swojej inteligencji nieadekwatnie w stosunku do rzeczywistych możliwości, jakie posiadają. Jak pokazały rezultaty dwóch badań przeprowadzonych z udziałem polskich studentów, uczestnicy z silna tendencja do odczuwania gniewu oceniali swoją inteligencję jako ponadprzeciętna, podczas gdy ich rzeczywisty wynik w testach inteligencji nie był zwiazany z cecha gniewu (Zajenkowski, Gignac, 2018). Co interesujące, inteligencję zalicza się do cech sprawczych (agentic traits), których wysoki poziom wiąże się z przypisywaniem sobie sprawczych kompetencji oraz wpływu na świat (Campbell, Rudich, Sedikides, 2002). Poczucie siły i kompetencji koresponduje zaś z odczuwana kontrolą i pewnością, co - ponownie - może wskazywać na istotność oceny poznawczej towarzyszącej emocji w wyjaśnianiu mechanizmów leżących u podstaw jej kognitywnych następstw. Warto nadmienić, że w opisywanym wyżej badaniach uwzględniono także neurotyczność, której pozytywny związek z gniewem został wielokrotnie udokumentowany (np. Bettencourt, Talley, Benjamin, Valentine, 2006; Ode, Robinson, Wilkowski, 2008). Jak się okazało, neurotyczność i cecha gniewu znosiły wzajemnie swój wpływ w relacji z subiektywną oceną własnej inteligencji. Kierunek zależności między każda z tych zmiennych a subiektywnie szacowaną inteligencją (subjectively assessed intelligence) SAI był odmienny, tj. SAI korelowała pozytywnie z gniewem, ale negatywnie z neurotycznością. Według autorów taki efekt może świadczyć o dwoistej naturze gniewu (Zajenkowski, Gignac, 2018). Pierwszy aspekt gniewu (mający swoje źródło w wysokiej neurotyczności) miałby przejawiać się w negatywnej emocjonalności i lękowym podłożu, drugi zaś (który pojawia się przy kontroli neurotyczności) - w motywacji dążeniowej. Pierwszy 
z nich odzwierciedlałby więc stronę gniewu obserwowaną głównie w wycofanej postawie i zachowaniach autodestrukcyjnych, z kolei drugi aspekt gniewu reprezentowałby jego pozytywną właściwość jako emocji sprzyjającej osiaganiu wyznaczonych celów. W tym miejscu warto również przytoczyć pracę Szymaniak i Kałowskiego (2020), którzy sprawdzali, na ile cecha gniewu łączy się z przeszacowaniem swoich zdolności do stosowania ironii. W powyższym badaniu zadaniem uczestników było zapoznanie się z opisem kilku hipotetycznych sytuacji, a następnie wskazanie, jak zareagowaliby w każdej z nich, wybierając jedna z czterech możliwych alternatyw (reprezentujących kolejno ironię, krytykę, wsparcie lub reakcję neutralna). Dodatkowo każda osoba wypełniła skale mierzące subiektywną skłonność do stosowania ironii oraz cechę gniewu. Jak się okazało, wyższe wyniki na skali gniewu wiązały się z wyższa deklarowaną tendencja do bycia ironicznym. Co ciekawe, obiektywnie mierzona ironia nie miała z gniewem nic wspólnego. Umiejętność stosowania ironii jest zdecydowanie bardziej poznawczo wymagająca niż komunikacja dosłowna (Gibbs, 2012) i może być uznawana za atut świadczący o wysokiej inteligencji. Przytoczone wyniki są więc kolejnym dowodem na to, że gniew łączy się z nadmiernie optymistyczną oceną siebie w zakresie specyficznych, powszechnie pożądanych zdolności poznawczych. Na poparcie tej tezy jest także pozytywna korelacja między subiektywnie stosowaną ironią a zarówno gniewem jak i narcyzmem (Szymaniak, Kałowski, Maciantowicz, w recenzji). Analiza regresji wykazała, że narcyzm przestawał istotnie wyjaśniać subiektywnie mierzoną ironię, gdy do modelu włączono gniew. Innymi słowy, można przypuszczać, że gniew łączy się z postrzeganiem siebie jako wysoko ironicznych przez osoby narcystyczne.

\section{GNIEW I ZACHOWANIA ZORIENTOWANE NA NAGRODĘ}

Kolejny przykład konsekwencji poznawczej za pośrednictwem której ujawnia się dążeniowa natura gniewu, to tendencja do kierowania uwagi w stronę tzw. bodźców nagradzających. Badania z użyciem eye-trackingu, czyli metody śledzenia ruchów gałek ocznych, przeprowadzone przez Ford i współpracowników (Ford i in., 2010; Ford i in., 2012), wykazały, że stan gniewu wzmacnia skłonność do kierowania i skupiania uwagi wzrokowej na bodźcach nagradzających. W swoich eksperymentach porównywali oni gniew z ekscytacją oraz strachem. Pierwszym krokiem każdego z badań było wzbudzenie jednej z tych emocji. Następnie badacze prezentowali uczestnikom pary afektywnie nacechowanych zdjęć. Każda para stanowiła kombinację nagradzających (np. deser, 
bodźce seksualne), zagrażających (np. rozkładające się ciało) lub neutralnych fotografii (np. samolot). Zadaniem uczestników było „uważne studiowanie” każdej z par obrazków wyświetlanych losowo na ekranie komputera. W trakcie tej części eksperymentu badacze mierzyli długość i częstotliwość skupiania wzroku na każdym zdjęciu z pary. Rezultaty wykazały, że w warunku z gniewem jako wzbudzoną emocją uczestnicy istotnie częściej patrzyli na bodźce nagradzające w porównaniu do tych zagrażających czy neutralnych. Ponadto to właśnie na bodźcach nagradzających najdłużej koncentrowali swój wzrok. Co istotne, podobną zależność zaobserwowano w warunku, w którym indukowaną emocją była ekscytacja (emocja o motywacji dążeniowej), zaś odwrotną w grupie osób odczuwających strach. Ci ostatni najczęściej i najdłużej wpatrywali się w fotografie o charakterze zagrażającym. Takie wyniki to kolejny dowód na motywacyjne podłoże poznawczych konsekwencji gniewu.

Związek między gniewem a wrażliwością na nagrodę udokumentowano także w innych badaniach (np. Aarts i in., 2010; Angus, Kemkes, Schutter, Harmon-Jones, 2015; Duek, Osher, Belmaker, Bersudsky, Kofman, 2014; Szymaniak, Zajenkowski, 2021). Przykładowo, w jednym z nich dowiedziono, że skłonność do odczuwania gniewu wiąże się z tym, jak bardzo lubimy (bądź nie lubimy) bodźce nagradzające. Mianowicie, w serii dwóch badań przeprowadzonych przez Szymaniak i Zajenkowskiego (2021) wysoki poziom cechy gniewu wiązał się z pozytywną oceną słów o charakterze nagradzającym. Mediatorem tej relacji okazała się być motywacja dążeniowa, a dokładnie jeden z jej wymiarów - wrażliwość na nagrodę ( $B A S$ reward responsiveness). Dodatkowo szczególną sympatią osób z wysoką tendencją do odczuwania gniewu cieszyły się te słowa, które jednocześnie powiązane były z wysokim pobudzeniem fizjologicznym (np. „zwycięzca”, „pocałunek”, „prezent”). Co ciekawe, jedna ze zmiennych wyjaśniających tę zależność był hedonizm. Pozytywna relacja między gniewem a skupieniem uwagi na nagrodzie została zaobserwowana również u dzieci (He i in., 2013). W badaniu przeprowadzonym przez He i in. (2013) 5- i 6-latki z silną tendencją do doświadczania gniewu potrzebowały więcej czasu na odwrócenie uwagi od sygnałów nagrody niż bodźców sygnalizujących karę.

Warto wspomnieć, że gniew i zachowania zorientowane na nagrodę posiadaja wspólne korelaty mózgowe. Możliwość ukarania osoby naruszającej normy społeczne powoduje zwiększoną aktywację grzbietowej części prążkowia - podkorowej struktury mózgu zaangażowanej m.in. w przetwarzanie bodźców nagradzających, które pojawiają się w efekcie działań zorientowanych na osiagnięcie celu (de Quervain i in., 2004). Indukcja gniewu zaś prowadzi 
do silniejszej aktywacji elektrofizjologicznych wskaźników wrażliwości na nagrodę (Angus i in., 2015). Co ważne, ta ostatnia jest również pozytywnie związana z poczuciem pewności i kontroli. Jak się okazuje, już samo przekonanie o kontrolowalności i przewidywalności sytuacji może być dla nas nagradzające. Poczucie kontroli powiązane jest z aktywacją sieci korowo-prążkowiowej obejmującej obszar prążkowia i kory przedczołowej (Tricomi, Delgado, Fiez, 2004). Kora przedczołowa zaangażowana jest w regulację procesów emocjonalnych i motywacyjnych (Ochsner, Gross, 2005). Co istotne, subiektywna percepcja kontroli (a nie koniecznie jej rzeczywiste posiadanie) wystarczy, by wymienione obszary mózgu zostały aktywowane (Mühlberger, Angus, Jonas, Harmon-Jones, Harmon-Jones, 2017).

Pozytywna relacja między gniewem, zarówno jako stanem, jak i cechą, a różnymi przejawami wrażliwości na sygnały nagrody jest kolejnym przykładem podobieństwa gniewu do pozytywnego afektu. Do tej pory zakładano, że skupianie się na nagrodzie jest domeną wyłącznie emocji pozytywnych (np. radości czy ekscytacji; Tamir, Robinson, 2007), a emocjom o walencji negatywnej przypisywano wyłącznie tendencję uwagi w kierunku bodźców sygnalizujących zagrożenie i karę (np. MacLeod, 1999; Mathews, MacLeod, 1985). Doniesienia na temat gniewu podważają ten podział, pokazując po raz kolejny, że sposób, w jaki postrzegamy otaczający nas świat, jest funkcją motywacyjnego podłoża doświadczanych przez nas emocji.

\section{GNIEW A PLANOWANIE I REALIZACJA PLANÓW}

Motywacyjna rola gniewu obecna jest także w procesie formułowania i wdrażania planów w życie. Powyższy wniosek można wyciagnąć na podstawie wyników uzyskanych przez Maglio i in. (2014), którzy w serii swoich badań sprawdzali wpływ gniewu na planowanie i realizację wyznaczonych celów. Pierwsze badanie wykazało, że pod wpływem gniewu formułujemy znacznie więcej planów niż pod wpływem smutku. Konkretnie, w pierwszej części eksperymentu uczestnicy wskazywali swoje najważniejsze cele akademickie. Następnie poddani zostali indukcji emocji smutku, gniewu lub warunku naturalnego. W kolejnym etapie proszono ich o przypomnienie sobie wcześniej sprecyzowanych celów, a następnie uzupełnienie czterech z ośmiu niedokończonych zdań. Połowa zdań miała format sugerujący intencję realizacji planu (np. „Jeśli ... się wydarzy, wtedy ja...”), druga zaś generalnych stwierdzeń w trybie przyszłym (np. „Ogólnie rzecz biorąc, będę...”). Rezultaty wykazały, że osoby odczuwają- 
ce gniew znacznie częściej kończyły zdania mające formę planu w porównaniu do osób odczuwających smutek lub stan neutralny.

W kolejnym eksperymencie powyższej serii sprawdzano wpływ emocji na realizację wcześniej sformułowanego planu (Maglio i in., 2004, badanie 3). Podobnie jak w poprzednim badaniu gniew porównywany był ze smutkiem. Zadaniem uczestników było możliwie najszybsze reagowanie na pojawiające się na ekranie liczby (bodziec krytyczny), a ignorowanie liter (bodziec niekrytyczny). Przed rozpoczęciem zadania następowała indukcja emocji. Dodatkowo połowa uczestników w każdym warunku różniącym się indukowaną emocja poddana została tzw. implementacji intencji. Implementacje intencji mają formę specyficznych planów typu ,jeżeli - to”, np. ,jeżeli zobaczę na ekranie cyfrę, to nacisnę klawisz X najszybciej jak to możliwe" (Gollwitzer, Sheeran, 2006). Zgodnie z oczekiwaniami badaczy, uczestnicy odczuwający gniew, w porównaniu do osób doświadczających smutek (emocję o negatywnej walencji i motywacji unikającej), z większym sukcesem realizowali wyznaczony plan (tj. naciskali klawisz X znacząco szybciej, gdy cyfra 3 pojawiała się na ekranie). Gniew wzmacniał również efekt implementacji intencji. Precyzując, najefektywniej swój plan realizowali uczestnicy doświadczający gniewu, którzy wcześniej świadomie wyrazili intencję realizacji planu. Maglio i in. (2014) przypisali efekt gniewu powiązanym z nim motywacji dążeniowej oraz ocenie poznawczej. W swoich badaniach kontrolowali deklarowany poziom poczucia kontroli i pewności, które okazały się być istotnym czynnikiem wyjaśniającym efektywność realizacji planu. Powyższe rezultaty korespondują z wcześniej przytoczonymi wynikami mówiącymi o kierunku motywacji jako determinancie poznawczych następstw gniewu.

\section{GNIEW A ZAKRES POZNAWCZY}

Dążeniowa koncepcja gniewu skłoniła badaczy do zweryfikowania także tego, jak gniew wpływa na zakres przetwarzania informacji. Przez wiele lat zakładano, że poszerzanie i zawężanie uwagi łączy się odpowiednio z emocjami o pozytywnej i negatywnej walencji (np. Easterbrook, 1959; Fredrickson, 2001). Jak jednak słusznie zauważyli Gable i in. (2015), poprzednie prace w tym obszarze uwzględniały jedynie pozytywne emocje o niskiej motywacji dążeniowej (np. rozbawienie) oraz negatywne emocje o wysokiej motywacji unikającej (np. strach). W serii czterech eksperymentów przeprowadzonych przez Gable’a i in. (2015) gniew - emocja o wysokiej intensywności motywacji - zawężał zakres przetwarzania informacji analogicznie do wysoko intensyw- 
nych emocji pozytywnych, zaś przeciwnie do emocji pozytywnych charakteryzujących się niską motywacją dążeniową. W trzech eksperymentach Gable i in. (2015) wykorzystali zadanie Navona (1997), które stosowane jest do badania percepcji wzrokowej. W tym zadaniu uczestnikom prezentuje się dużą literę złożoną z innych liter o mniejszym rozmiarze (np. duża litera $\mathrm{H}$ składająca się z mniejszych liter F; zob. rysunek 1). Zadaniem uczestników było wskazanie, w możliwie najszybszym czasie, czy zaprezentowane im obrazki przedstawiaja literę dużą (tj. H) czy małą (tj. F). Wskaźnikiem przetwarzania globalnego był szybszy czas reakcji na litery duże oraz wolniejszy czas reakcji na litery małe. Wskaźnikiem przetwarzania lokalnego był, odpowiednio, szybszy czas reakcji na litery małe oraz wolniejszy czas reakcji na litery duże. Jak pokazały rezultaty, stan gniewu, przeciwnie do smutku, powodował, że uczestnicy znacząco szybciej identyfikowali litery małe niż duże. Podobne rezultaty z wykorzystaniem tej miary otrzymano także w innych badaniach (np. Gable, Harmon-Jones, 2008, 2011; Nittono, Fukushima, Yano, Moriya, 2012; Price, Harmon-Jones, 2010). Co warte podkreślenia, wpływ gniewu odnotowano także w przypadku zawężania zakresu semantycznego. W czwartym eksperymencie przytoczonej wyżej serii badań (Gable i in., 2015) zaraz po indukcji gniewu uczestnicy mieli za zadanie wskazać, jak dobrym reprezentantem danej kategorii (np. pojazd) jest dany przedmiot (np. samochód, wielbłąd). Wskaźnikiem zawężania zakresu semantycznego były niższe oceny na skali przynależności do kategorii (category belongingness). Stan gniewu powodował, że oceny uczestników były zdecydowanie surowsze (częściej uznawali dany przedmiot za niereprezentatywny) niż oceny uczestników w warunku neutralnym.

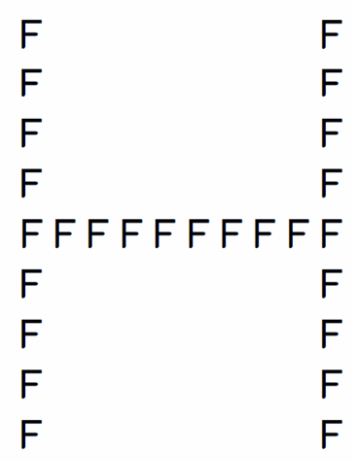

Rysunek 1. Praylktadony bodzৃiec uisywany w zadaniu Navona (1977). 
Rola intensywności motywacji została odnotowana także w relacji między gniewem a zakresem pamięciowym. Threadgill i Gable (2019) poświęcili temu zagadnieniu serię pięciu eksperymentów. Rezultaty pierwszych dwóch pokazały, że gniew jako stan ułatwia zapamiętywanie informacji prezentowanych w centralnej części ekranu. W swoich następstwach gniew podobny był do przerażenia (obydwie emocje charakteryzują się wysoką intensywnością motywacji), a odmienny od smutku. Przerażenie i gniew zawężały zakres pamięci. Smutek, stan o niskiej intensywności motywacji, ułatwiał zapamiętywanie informacji prezentowanych peryferyjnie. Taki schemat wyników dowodzi, że charakterystyką wspólną dla emocji zawężających zakres poznawczy i pamięciowy (np. wstrętu, pożądania i strachu) oraz grupy emocji je poszerzających (np. radości i smutku) jest intensywność motywacji towarzyszącej danej emocji, a nie jej walencja. Innymi słowy, emocje o wysokiej intensywności motywacji sprawiają że łatwiej zapamiętujemy szczegóły docierających do nas informacji, podczas gdy emocje o niskiej intensywności motywacji ułatwiaja przetwarzanie globalne i całościowe. Relacja ta jest niezależna od tego, czy odczuwanie danej emocji jest dla nas przyjemne, czy nieprzyjemne.

\section{GNIEW I JEGO ZASTOSOWANIE W ŻYCIU CODZIENNYM}

Oprócz niepodważalnej wartości naukowej badania dążące do zrozumienia natury gniewu posiadaja także szereg implikacji praktycznych. Gniew, poprzez swój silny komponent motywacyjny, może pomagać nam w stawianiu czoła wyzwaniom oraz mobilizować do realizacji swoich planów. Co ciekawe, według powszechnej opinii, ludzie nie chcą odczuwać emocji nieprzyjemnych, dążąc jedynie do tego, by „czuć się dobrze” (np. Thayer, 2000; Tice, Baumeister, Zhang, 2004). Jak się jednak okazuje, to założenie jest mylne. W literaturze odnaleźć można opis okoliczności, w których gniew jest dla nas emocją wręcz pożądana (np. Tamir, 2016; Tamir, Mitchell, Gross, 2008). Przykładowo w badaniu Tamir, Forda i Ryan (2013) uczestnicy postawieni w sytuacji negocjacji z nieznajomą osobą deklarowali chęć odczuwania gniewu choćby w minimalnym stopniu. Podobnie, preferujemy odczuwanie gniewu (a nie np. radości), gdy chcemy skonfrontować kogoś, kto dopuścił się wobec nas nadużycia (Tamir, Ford, 2012; Tamir i in., 2008). Preferencja odczuwania danej emocji nie zawsze idzie jednak w parze z jego rzeczywistym doświadczaniem. Współcześnie nadal wielu badaczy skupia się wyłącznie na negatywnych konsekwencjach gniewu, proponując tym samym szereg narzędzi pomocnych w jego kontroli (np. Deffenbacher, Huff, Lynch, Oetting, Salvatore, 2000; Feindler, Ecton, 
1986; Sukhodolsky, Solomon, Perine, 2000). Dodatkowo jedną z najczęściej stosowanych strategii samoregulacji gniewu jest supresja (np. Cheung, Park, 2010; Vögele, Jarvis, Cheeseman, 1997). Supresja gniewu odnosi się do częstotliwości, z jaką doświadczamy gniewu, ale go nie wyrażamy (Spielberger, 1999). Zgodnie z teoria ironicznego przetwarzania (ironic process theory; Wegner, 1994), której założenia zostały potwierdzone także na gruncie empirycznym (np. Quartana, Burns, 2007), tłumienie gniewu zwiększa dostępność poznawcza powiązanych z nim myśli, przez co - paradoksalnie - wzmaga doświadczany gniew. Jak wielokrotnie wykazano, tłumienie tej emocji może być bardzo kosztowne dla naszego zdrowia psychicznego i fizycznego (np. Begley, 1994; Deffenbacher i in., 1996). Supresja gniewu sprzyja depresyjności (Riley, Treiber, Woods, 1989) oraz obniża poczucie satysfakcji z życia (John, Gross, 2004). Osoby z wysoką tendencją do tłumienia gniewu są także bardziej podatne na doświadczanie braku społecznego wsparcia (Palfai, Hart, 1997). Zdecydowanie bardziej adaptacyjną forma radzenia sobie z gniewem jest przeformułowanie poznawcze (cognitive reappraisal; Gross, 1999; Mauss, Cook, Cheng, Gross, 2007). Strategia ta polega na reinterpretacji sytuacji tak, by nadać jej nowe znaczenie, a w konsekwencji zastapić pierwotnie wywołane przez nią emocje adaptacyjnym stanem emocjonalnym (Lazarus, Alfert, 1964). Przykładem może być sytuacja, w której odczuwamy gniew w odpowiedzi na surową krytykę naszej pracy. Zamiast interpretować uwagi jako celową złośliwość, możemy uznać je za wartościową wskazówkę dotyczącą obszarów, nad którymi powinniśmy popracować, by podnieść swoje kompetencje jako pracownika.

O ile wiele jest kontekstów, w których powinniśmy dążyć do redukcji gniewu, są również okoliczności, w jakich odczuwanie tej emocji może być dla nas korzystne. Świadczą o tym wybrane poznawcze konsekwencje gniewu przybliżone w tym rozdziale. Tendencja do wydawania optymistycznych sądów może uosabiać „wrażenie oczywistości i prostoty” sytuacji, o której wspomina Olga Tokarczuk w przytoczonym na początku rozdziału cytacie. Optymistyczna ocena sprzyja wytrwałości w pokonywaniu ewentualnych przeszkód, zwiększając tym samym szanse na osiagnięcie wyznaczonego celu (Scheier, Carver, 1985). Gniew, poprzez swój silny komponent dążeniowy, może też mobilizować do walki przeciw niesprawiedliwości i naruszaniu praw mniejszości oraz motywować do stawania w obronie pokrzywdzonych (np. Rozin, Lowery, Imada, Haidt, 1999). Towarzyszące mu poczucie pewności może wzmacniać w nas przekonanie, że posiadamy wystarczające zasoby, by im sprostać, a zwiększona wrażliwość na nagrodę może być pomocna w odwracaniu uwagi od potencjalnych trudności i zagrożeń. Wbrew powszechnej intuicji, okazywanie gniewu 
może także służyć wzmacnianiu relacji interpersonalnych. Często bowiem, oprócz pierwotnej reakcji dążącej do ukarania osoby, która nas skrzywdziła, towarzyszy mu nadzieja, że w następstwie się z nią pojednamy.

Konkludując, dociekania nad gniewem i jego poznawczymi następstwami to obiecujący krok na drodze do wyjaśnienia, dlaczego niektóre emocje dla nas nieprzyjemne wpływają na poznanie podobnie jak pozytywny afekt. Wyniki wyżej zreferowanych badań jednoznacznie wskazują no rolę aspektu motywacyjnego w kształtowaniu poznawczych następstw gniewu i emocji per se. Znajomość tych konsekwencji może pomóc nam w świadomym zarządzaniu emocjami, promując tym samym doświadczanie gniewu w sytuacjach, w których jest ono dla nas adaptacyjne.

\section{BIBLIOGRAFIA}

Aarts, H., Ruys, K., Veling, H., Renes, R., de Groot, J., van Nunen, A., Geertjes, S. (2010). The art of anger: Reward context turns avoidance responses to anger-related objects into approach. Psychological Science, 21(10), 1406-1410. https://doi. org/10.1177/0956797610384152

Allen, D. (2003). Angry bees, wasps and jurors: The symbolic politics of ógrn in Athens. W: S. Braund, G. W. Most (red.), Ancient anger perspectives from Homer to Galen, t. 32 (s. 76-98). Cambridge: Cambridge University Press.

Angus, D., Kemkes, K., Schutter, D., Harmon-Jones, E. (2015). Anger is associated with reward-related electrocortical activity: Evidence from the reward positivity. Psychophysiology, 52, 1271-1280. https://doi.org/10.1111/psyp.12460

Averill, J. (1983). Studies on anger and aggression: Implications for theories of emotion. American Psychologist, 38, 1145-1160. https://doi.org/10.1037/0003066x.38.11.1145

Baron, K., Smith, T., Butner, J., Nealey-Moore, J., Hawkins, M., Uchino, B. (2006). Hostility, anger, and marital adjustment: Concurrent and prospective associations with psychosocial vulnerability. Journal of Behavioral Medicine, 30(1), 1-10. https:// doi.org/10.1007/s10865-006-9086-z

Begley, T. (1994). Expressed and suppressed anger as predictors of health complaints. Journal of Organizational Behavior, 15(6), 503-516. https://doi.org/10.1002/ job.4030150603

Berkowitz, L. (1993). Aggression: Its causes, consequences, and control. Nowy Jork: Mcgraw-Hill Book Company. 
Bettencourt, B., Talley, A., Benjamin, A., Valentine, J. (2006). Personality and aggressive behavior under provoking and neutral conditions: A meta-analytic review. Psychological Bulletin, 132(5), 751-777. https://doi.org/10.1037/0033-2909.132.5.751

Brickhouse, T., Smith, N. (2015). Socrates on the emotions. Plato Journal, 15, 9 -28. https://doi.org/10.14195/2183-4105_15_1

Buss, A., Perry, M. (1992). The aggression questionnaire. Journal of Personality and Social Psychology, 63, 452-459. https://doi.org/10.1037/0022-3514.63.3.452

Cacioppo, J., Gardner, W., Berntson, G. (1999). The affect system has parallel and integrative processing components: Form follows function. Journal of Personality and Social Psychology, 76, 839-855. https://doi.org/10.1037/0022-3514.76.5.839

Campbell, W., Rudich, E., Sedikides, C. (2002). Narcissism, self-esteem, and the positivity of self-views: Two portraits of self-love. Personality and Social Psychology Bulletin, 28(3), 358-368. https://doi.org/10.1177/0146167202286007

Carver, C., Harmon-Jones, E. (2009). Anger is an approach-related affect: Evidence and implications. Psychological Bulletin, 135(2), 183-204. https://doi.org/10.1037/ a0013965

Cheung, R., Park, I. (2010). Anger suppression, interdependent self-construal, and depression among Asian American and European American college students. Cultural Diversity and Ethnic Minority Psychology, 16(4), 517-525. https://doi.org/10.1037/ a0020655

de Quervain, D., Fischbacher, U., Treyer, V., Schellhammer, M., Schnyder, U., Buck, A., Fehr, E. (2004). The neural basis of altruistic punishment. Science, 305(5688), 1254-1258. https://doi.org/10.1126/science.1100735

Deffenbacher, J. (1992). Trait anger: Theory, findings, and implications. Advances in Personality Assessment, 9, 177-201. https://doi.org/10.1037/0022-0167.43.2.131

Deffenbacher, J., Huff, M., Lynch, R., Oetting, E., Salvatore, N. (2000). Characteristics and treatment of high-anger drivers. Journal of Counseling Psychology, 47(1), 5-17. https://doi.org/10.1037/0022-0167.47.1.5

Deffenbacher, J., Oetting, E., Lynch, R., Morris, C. (1996). The expression of anger and its consequences. Behaviour Research and Therapy, 34(7), 575-590. https://doi. org/10.1016/0005-7967(96)00018-6

Depue, R., Zald, D. (1993). Biological and environmental processes in nonpsychotic psychopathology: A neurobehavioral perspective. W: C. Costello (red.), Basic issues in psychopathology (s. 127-237). Nowy Jork: Guilford Press.

Diong, S., Bishop, G. (1999). Anger expression, coping styles, and well-being. Journal of Health Psychology, 4(1), 81-96. https://doi.org/10.1177/135910539900400106 
Duek, O., Osher, Y., Belmaker, R., Bersudsky, Y., Kofman, O. (2014). Reward sensitivity and anger in euthymic bipolar disorder. Psychiatry Research, 215(1), 95-100. https:// doi.org/10.1016/j.psychres.2013.10.028

Dunn, J., Schweitzer, M. (2005). Feeling and believing: The influence of emotion on trust. Journal of Personality and Social Psychology, 88(5), 736-748. https://doi. org/10.5465/ambpp.2003.13793140

Easterbrook, J. (1959). The effect of emotion on cue utilization and the organization of behavior. Psychological Review, 66(3), 183-201. https://doi.org/10.1037/ h0047707

Ekman, P. (1992). An argument for basic emotions. Cognition and Emotion, 6(3-4), 169-200. https://doi.org/10.1080/02699939208411068

Feindler, E., Ecton, R. (1986). Adolescent anger control: Cognitive-behavioral techniques. Nowy Jork: Pergamon Press. https://doi.org/10.1002/1520-6807(199201)29:1<87::AIDPITS2310290115>3.0.CO;2-3

Fischhoff, B., Gonzalez, R., Lerner, J., Small, D. (2005). Evolving judgments of terror risks: Foresight, hindsight, and emotion. Journal of Experimental Psychology: Applied, 11(2), 124-139. https://doi.org/10.1037/1076-898x.11.2.124

Ford, B., Tamir, M., Brunye, T., Shirer, R., Mahoney, C., Taylor, H. (2010). Keeping your eyes on the prize: Anger and visual attention to threats and rewards. Psychological Science, 21(8), 1098-1105. https://doi.org/10.1177/0956797610375450

Ford, B., Tamir, M., Gagnon, S., Taylor, H., Brunyé, T. (2012). The angry spotlight: Trait anger and selective visual attention to rewards. European Journal of Personality, 26(2), 90-98. https://doi.org/10.1002/per.1840

Fredrickson, B. (1998). What good are positive emotions? Review of General Psychology, 2(3), 300-319. https://doi.org/10.1037/1089-2680.2.3.300

Fredrickson, B. (2001). The role of positive emotions in positive psychology. The broaden-and-build theory of positive emotions. The American Psychologist, 56(3), 218-226. https://doi.org/10.1037/0003-066x.56.3.218

Gable, P., Harmon-Jones, E. (2008). Approach-motivated positive affect reduces breadth of attention. Psychological Science, 19(5), 476-482. https://doi.org/10.1111/ j.1467-9280.2008.02112.x

Gable, P., Harmon-Jones, E. (2011). Attentional consequences of pregoal and postgoal positive affects. Emotion, 11(6), 1358-1367. https://doi.org/10.1037/ a0025611

Gable, P., Harmon-Jones, E. (2013). Does arousal per se account for the influence of appetitive stimuli on attentional scope and the late positive potential? Psychophysiology, 50(4), 344-350. https://doi.org/10.1111/psyp.12023 
Gable, P., Poole, B., Harmon-Jones, E. (2015). Anger perceptually and conceptually narrows cognitive scope. Journal of Personality and Social Psychology, 109(1), 163-174. https:// doi.org/10.1037/a0039226

Gibbs, R. W., Jr. (2012). Are ironic acts deliberate? Journal of Pragmatics, 44(1), 104 115. https://doi.org/10.1016/j.pragma.2011.11.001

Gollwitzer, P., Sheeran, P. (2006). Implementation intentions and goal achievement: A meta-analysis of effects and processes. Advances in Experimental Social Psychology, 38, 69-119. https://doi.org/10.1016/s0065-2601(06)38002-1

Gross, J. (1999). Emotion and emotion regulation. W: L. Pervin, O. John (red.), Handbook of personality: Theory and research (s. 525-552). Nowy Jork: Guilford.

Hansen, C., Hansen, R. (1988). Finding the face in the crowd: An anger superiority effect. Journal of Personality and Social Psychology, 54(6), 917-924. https://doi. org/10.1037/0022-3514.54.6.917

Hanson, A. (2003). „Your mother nursed you on bile”: Anger in babies and small children. W: S. Braund, G. W. Most (red.), Ancient anger: Perspectives from Homer to Galen, t. 32 (s. 185-207). Cambridge: Cambridge University Press.

Harmon-Jones, E. (2003). Anger and the behavioral approach system. Personality and Individual Differences, 35(5), 995-1005. https://doi.org/10.1016/s01918869(02)00313-6

Harmon-Jones, E., Allen, J. (1998). Anger and frontal brain activity: EEG asymmetry with approach motivation despite negative affective valence. Journal of Personality and Social Psychology, 74(5), 1310-1316. https://doi.org/10.1037//00223514.74.5.1310

Harmon-Jones, E., Gable, P., Price, T. (2013). Does negative affect always narrow and positive affect always broaden the mind? Considering the influence of motivational intensity on cognitive scope. Current Directions in Psychological Science, 22(4), 301-307. https://doi.org/10.1177/0963721413481353

Harmon-Jones, E., Harmon-Jones, C., Abramson, L., Peterson, C. (2009). PANAS positive activation is associated with anger. Emotion, 9(2), 183-196. https://doi. org/10.1037/a0014959

Harmon-Jones, E., Harmon-Jones, C., Price, T. (2013). What is approach motivation? Emotion Review, 5(3), 291-295. https://doi.org/10.1177/1754073913477509

Harmon-Jones, E., Sigelman, J. (2001). State anger and prefrontal brain activity: Evidence that insult- related relative left-prefrontal activation is associated with experienced anger and aggression. Journal of Personality and Social Psychology, 80(5), 797-803. https://doi.org/10.1037/0022-3514.80.5.797

Harmon-Jones, E., Sigelman, J., Bohlig, A., Harmon-Jones, C. (2003). Anger, coping, and frontal cortical activity: The effect of coping potential on an- 
ger-induced left frontal activity. Cognition and Emotion, 17(1), 1-24. https://doi. org/10.1080/02699930302278

Harris, W. (2001). Restraining rage: The ideology of anger control in classical antiquity. Cambridge: Harvard University Press. https://doi.org/10.4159/9780674038356

He, J., Jin, X., Zhang, M., Huang, X., Shui, R., Shen, M. (2013). Anger and selective attention to reward and punishment in children. Journal of Experimental Child Psychology, 115(3), 389-404. https://doi.org/10.1016/j.jecp.2013.03.004

Hortensius, R., Schutter, D., Harmon-Jones, E. (2011). When anger leads to aggression: Induction of relative left frontal cortical activity with transcranial direct current stimulation increases the anger-aggression relationship. Social Cognitive and Affective Neuroscience, 7(3), 342-347. https://doi.org/10.1093/scan/nsr012

Izard, C. (2010). The many meanings/aspects of emotion: Definitions, functions, activation, and regulation. Emotion Review, 2(4), 363-370. https://doi. org/10.1177/1754073910374661

John, O., Gross, J. (2004). Healthy and unhealthy emotion regulation: Personality processes, individual differences, and life span development. Journal of Personality, 72(6), 1301-1334. https://doi.org/10.1111/j.1467-6494.2004.00298.x

Johnson, E. (1990). The deadly emotions: The role of anger, hostility, and aggression in bealth and emotional well-being. Nowy Jork: Praeger Publishers.

Kaufman, D. (2014). Seneca on the analysis and therapy of occurrent emotions. W: J. Wildberger, M. L. Colish (red.), Seneca philosophus (s. 111-133). Berlin: De Gruyter. https://doi.org/10.1515/9783110349863.111

Lai, W. (1990). Looking for Mr. Ho Po: Unmasking the river god of ancient China. History of Religions, 29(4), 335-350.

Lang, P. (1995). The emotion probe: Studies of motivation and attention. American Psychologist, 50(5), 372-385. https://doi.org/10.1037/0003-066X.50.5.372

Lazarus, R., Alfert, E. (1964). Short-circuiting of threat by experimentally altering cognitive appraisal. Journal of Abnormal and Social Psychology, 69(2), 195-205. https://doi.org/10.1037/h0044635

Lerner, J., Gonzalez, R., Small, D., Fischhoff, B. (2003). Effects of fear and anger on perceived risks of terrorism. Psychological Science, 14(2), 144-150. https://doi. org/10.1111/1467-9280.01433

Lerner, J., Keltner, D. (2000). Beyond valence: Toward a model of emotion-specific influences on judgement and choice. Cognition \& Emotion, 14(4), 473-493. https:// doi.org/10.1080/026999300402763

Lerner, J., Keltner, D. (2001). Fear, anger, and risk. Journal of Personality and Social Psychology, 81(1), 146-159. https://doi.org/10.1037//O022-3514.81.1.146 
Leslie, C. (1998). Asian medical systems: A comparative study. Delhi: Motilal Banarsidass Publishing House.

Lewis, M., Alessandri, S., Sullivan, M. (1990). Violation of expectancy, loss of control, and anger expressions in young infants. Developmental Psychology, 26(5), 745-751. https://doi.org/10.1037/0012-1649.26.5.745

Liebsohn, M., Oetting, E., Deffenbacher, J. (1994). Effects of trait anger on alcohol consumption and consequences. Journal of Child and Adolescent Substance Abuse, 3(3), 17-32. https://doi.org/10.1300/j029v03n03_02

Litvak, P., Lerner, J., Tiedens, L., Shonk, K. (2010). Fuel in the fire: How anger impacts judgment and decision making. W: M. Potegal, G. Stemmler, C. Spielberger (red.), International handbook of anger (s. 287-311). Nowy Jork: Springer. https:/ / doi.org/10.1007/978-0-387-89676-2_17

MacLeod, C. (1999). Anxiety and anxiety disorders. W: T. Dalgleish, M. J. Power (red.), Handbook of cognition and emotion (s. 447-477). Chichester: Wiley.

Maglio, S., Gollwitzer, P., Oettingen, G. (2014). Emotion and control in the planning of goals. Motivation and Emotion, 38(5), 620-634. https://doi.org/10.1007/s11031014-9407-4

Mathews, A., MacLeod, C. (1985). Selective processing of threat cues in anxiety states. Behaviour Research and Therapy, 23(5), 563-569. https://doi.org/10.1016/00057967(85)90104-4

Mauss, I., Cook, C., Cheng, J., Gross, J. (2007). Individual differences in cognitive reappraisal: Experiential and physiological responses to an anger provocation. International Journal of Psychophysiology, 66(2), 116-124. https://doi.org/10.1016/j. ijpsycho.2007.03.017

Mühlberger, C., Angus, D., Jonas, E., Harmon-Jones, C., Harmon-Jones, E. (2017). Perceived control increases the reward positivity and stimulus preceding negativity. Psychophysiology, 54(2), 310-322. https://doi.org/10.1111/psyp.12786

Navon, D. (1977). Forest before trees: The precedence of global features in visual perception. Cognitive Psychology, 9(3), 353-383. https://doi.org/10.1016/00100285(77)90012-3

Nittono, H., Fukushima, M., Yano, A., Moriya, H. (2012). The power of kawaii: Viewing cute images promotes a careful behavior and narrows attentional focus. PLoS One, 7(9), e46362. https://doi.org/10.1371/journal.pone.0046362

Ochsner, K., Gross, J. (2005). The cognitive control of emotion. Trends in Cognitive Sciences, 9(5), 242-249. https://doi.org/10.1016/j.tics.2005.03.010

Ode, S., Robinson, M., Wilkowski, B. (2008). Can one's temper be cooled? A role for agreeableness in moderating neuroticism's influence on anger and aggres- 
sion. Journal of Research in Personality, 42(2), 295-311. https://doi.org/10.1016/j. jrp.2007.05.007

Palfai, T., Hart, K. (1997). Anger coping styles and perceived social support. Journal of Social Psychology, 137(4), 405-411. https://doi.org/10.1080/00224549709595455

Plutchik, R. (1980). Emotions: A psychoevolutionary synthesis. Nowy Jork: Harper and Row.

Potegal, M., Novaco, R. (2010). A brief history of anger. W: M. Potegal, G. Stemmler, C. Spielberger (red.), International handbook of anger (s. 9-24). Nowy Jork: Springer. https://doi.org/10.1007/978-0-387-89676-2_2

Price, T., Harmon-Jones, E. (2010). The effect of embodied emotive states on cognitive categorization. Emotion, 10(6), 934-938. https://doi.org/10.1037/a0019809

Quartana, P., Burns, J. (2007). Painful consequences of anger suppression. Emotion, 7(2), 400-414. https://doi.org/10.1037/1528-3542.7.2.400

Richardson, C., Halliwell, E. (2008). Boiling point. Problem anger and what we can do about it. Pobrane z: https://www.mentalhealth.org.uk/sites/default/files/boilingpoint.pdf

Riley, W., Treiber, F., Woods, M. (1989). Anger and hostility in depression. Journal of Nervous and Mental Disease, 177(11), 668-674. https://doi.org/10.1097/00005053198911000-00002

Rozin, P., Lowery, L., Imada, S., Haidt, J. (1999). The CAD triad hypothesis: A mapping between three moral emotions (contempt, anger, disgust) and three moral codes (community, autonomy, divinity). Journal of Personality and Social Psychology, 76(4), 574-586. https://doi.org/10.1037/0022-3514.76.4.574

Scheier, M., Carver, C. (1985). Optimism, coping, and health: Assessment and implications of generalized outcome expectancies. Health Psychology, 4(3), 219-294. https:// doi.org/10.1037/0278-6133.4.3.219

Scherer, K., Tannenbaum, P. (1986). Emotional experiences in everyday life: A survey approach. Motivation and Emotion, 10(4), 295-314. https://doi.org/10.1007/ bf00992106

Scherer, K., Wallbott, H. (1994). Evidence for universality and cultural variation of differential emotion response patterning. Journal of Personality and Social Psychology, 66(2), 310-328. https://doi.org/10.1037/0022-3514.66.2.310

Seneka, L. (45/1898). Minor dialogues, together with the dialogue On clemency. Londyn: George Bell \& Sons.

Shaver, P., Schwartz, J., Kirson, D., O’Connor, C. (1987). Emotion knowledge: Further exploration of a prototype approach. Journal of Personality and Social Psychology, 52(6), 1061-1086. https://doi.org/10.1037/0022-3514.52.6.1061

Siegman, A. W., Smith, T. (red.). (1994). Anger, hostility, and the heart. Hillsdale: Lawrence Erlbaum Associates, Inc. 
Siewert, K., Kubiak, T., Jonas, C., Weber, H. (2011). Trait anger moderates the impact of anger-associated rumination on social well-being. Personality and Individual Differences, 51(6), 769-774. https://doi.org/10.1016/j.paid.2011.06.030

Silberman, E., Weingartner, H. (1986). Hemispheric lateralization of functions related to emotion. Brain and Cognition, 5(3), 322-353. https://doi.org/10.1016/02782626(86)90035-7

Smith, C., Ellsworth, P. (1985). Patterns of cognitive appraisal in emotion. Journal of Personality and Social Psychology, 48, 813-838. https://doi.org/10.1037/00223514.48.4.813

Spielberger, C. (1988). Manual for the State-Trait Anger Expression Inventory. Odessa: Psychological Assessment Resources.

Spielberger, C. (1999). State-Trait Anger Expression Inventory-2. Odessa: Psychological Assessment Resource Inc.

Sukhodolsky, D., Solomon, R., Perine, J. (2000). Cognitive-behavioral, anger-control intervention for elementary school children: A treatment-outcome study. Journal of Child and Adolescent Group Therapy, 10(3), 159-170. https://doi. org/10.1023/A:1009488701736

Sullivan, M., Lewis, M. (2003). Contextual determinants of anger and other negative expressions in young infants. Developmental Psychology, 39(4), 693-705. https://doi. org/10.1037/0012-1649.//39.4.693

Szymaniak, K., Kałowski, P. (2020). Trait anger and sarcasm use. Personality and Individual Differences, 154, 109662. https://doi.org/10.1016/j.paid.2019.109662

Szymaniak, K., Kałowski, P., Maciantowicz, O. (w recenzji). Wisest in the room: Exploring the links between trait anger, narcissism, and self-reported sarcasm use. Personality and Individual Differences.

Szymaniak, K., Zajenkowski, M. (2021). How do high trait anger people feel about rewards high and low in arousal? Disentangling the association between trait anger and subjective pleasantness of rewards. Personality and Individual Differences, 168(10), 110278. https://doi.org/10.1016/j.paid.2020.110278

Tamir, M. (2016). Why do people regulate their emotions? A taxonomy of motives in emotion regulation. Personality and Social Psychology Review, 20(3), 199-222. https:// doi.org/10.1177/1088868315586325

Tamir, M., Ford, B. (2012). When feeling bad is expected to be good: Emotion regulation and outcome expectancies in social conflicts. Emotion, 12(4), 807-816. https://doi.org/10.1037/a0024443

Tamir, M., Ford, B., Ryan, E. (2013). Nonconscious goals can shape what people want to feel. Journal of Experimental Social Psychology, 49(2), 292-297. https://doi. org/10.1016/j.jesp.2012.11.009 
Tamir, M., Mitchell, C., Gross, J. (2008). Hedonic and instrumental motives in anger regulation. Psychological Science, 19(4), 324-328. https://doi.org/10.1111/j.14679280.2008.02088.x

Tamir, M., Robinson, M. (2007). The happy spotlight: Positive mood and selective attention to rewarding information. Personality and Social Psychology Bulletin, 33(8), 1124-1136. https://doi.org/10.1177/0146167207301030

Thayer, R. (2000). Mood regulation and general arousal systems. Psychological Inquiry, 11(3), 202-204.

Threadgill, A., Gable, P. (2019). Negative affect varying in motivational intensity influences scope of memory. Cognition and Emotion, 33(2), 332-345. https://doi. org/10.1080/02699931.2018.1451306

Tice, D., Baumeister, R., Zhang, L. (2004). The role of emotion in self-regulation: Differing role of positive and negative emotions. W: P. Philippot, R. S. Feldman (red.), The regulation of emotion (s. 213-226). Hillsdale: Lawrence Erlbaum Associates Publishers.

Tokarczuk, O. (2017). Prowadź swój pług przę kości umarlych. Kraków: Wydawnictwo Literackie.

Tricomi, E., Delgado, M., Fiez, J. (2004). Modulation of caudate activity by action contingency. Neuron, 41(2), 281-292. https://doi.org/10.1016/s08966273(03)00848-1

Van Kleef, G., De Dreu, C., Manstead, A. (2004). The interpersonal effects of anger and happiness in negotiations. Journal of Personality and Social Psychology, 86(1), 57-76. https://doi.org/10.1037/0022-3514.86.1.57

Vögele, C., Jarvis, A., Cheeseman, K. (1997). Anger suppression, reactivity, and hypertension risk: Gender makes a difference. Annals of Behavioral Medicine, 19(1), 61-69. https://doi.org/10.1007/bf02883428

Watson, D., Wiese, D., Vaidya, J., Tellegen, A. (1999). The two general activation systems of affect: Structural findings, evolutionary considerations, and psychobiological evidence. Journal of Personality and Social Psychology, 76(5), 820-838. https:/ / doi.org/10.1037/0022-3514.76.5.820

Wegner, D. (1994). Ironic processes of mental control. Psychological Review, 101(1), 34-52. https://doi.org/10.1037/0033-295x.101.1.34

Zajenkowski, M., Gignac, E. (2018). Why do angry people overestimate their intelligence? Neuroticism as a suppressor of the association between trait-anger and subjectively assessed intelligence. Intelligence, 70, 12-21. https://doi.org/10.1016/j. intell.2018.07.003 



\section{7.}

\section{Rozum czy serce?}

0 powiązaniach pomiędzy zdolnościami poznawczymi i społeczno-emocjonalnymi a religijnością ${ }^{1}$

Paweł Łowicki iD https://orcid.org/0000-0001-6012-6287

Uniwersytet Warszawski, Wydział Psychologii

pawel.lowicki@psych.uw.edu.pl

1 Publikacja powstała dzięki wsparciu finansowemu Narodowego Centrum Nauki w ramach grantu nr 2017/27/N/HS6/00541. 
„Chrześcijanin myśli nie tylko głowa, myśli również sercem i duchem, którego ma w sobie"

Papież Franciszek (2013)

\section{WPROWADZENIE}

Według szacunków amerykańskiej agencji badawczej Pew Research Center, w 2015 roku aż 84\% światowej populacji identyfikowało się z jakimś wyznaniem lub grupą religijną (Pew Research Center, 2017). Co ciekawe, najnowsze prognozy sugeruja ponadto, że udział osób niereligijnych w ogólnej populacji będzie w dalszym ciągu spadać i osiagnie poziom ok. 13\% w roku 2060. Wydaje się zatem, iż wbrew obiegowym opiniom dotyczącym malejącej roli religijności w społeczeństwach, religie nie sa jedynie tworem przeszłości i maja wciąż silne zakorzenienie we współczesnym świecie. Choć religia jest istotnym elementem życia tak wielu ludzi, to pozostaje ona jednak wciąż jednym z najmniej poznanych aspektów życia społecznego człowieka. Taka sytuacja może wynikać z różnych czynników, ale z pewnością przyczynia się do niej już także trudność w precyzyjnym zdefiniowaniu samego pojęcia „religijność”.

W kontekście psychologicznym religijność była dotąd zazwyczaj ujmowana jako pewna względnie stała dyspozycja dotycząca wiary w rzeczywistość nadprzyrodzona, którą można badać przy pomocy metod kwestionariuszowych (zob. Allport, Ross, 1967). W ostatnim czasie zauważono jednak również, że religijność może podlegać bardziej dynamicznym zmianom w czasie, a co za tym idzie, jej poziom być zależny od konkretnych czynników sytuacyjnych i może, w szczególności, być przedmiotem manipulacji eksperymentalnej (por. Gervais, Norenzayan, 2012). Co istotne, wobec złożoności systemów religijnych oraz różnorodności wyznań na świecie współczesna psychologia religii postuluje przyjęcie tzw. „podejścia komponentowego” (building-block approach) do badania zagadnień religijnych. W tym ujęciu religijność zostaje rozbita na poszczególne składniki, które mogą być analizowane z perspektywy naukowej (Taves, 2013). Najczęściej badanymi komponentami tak ujmowanej religijności 
są: przekonania religijne (tj. wiara w Boga/Siłę Wyższa) oraz indywidualna i publiczna praktyka religijna (czyli odpowiednio np. modlitwa oraz udział w nabożeństwach; por. Atran, Norenzayan, 2004; Huber, Huber, 2012).

W ostatnich latach zaobserwować można dynamiczny rozwój badań, które sytuują religijność w szerszym kontekście nauk o poznaniu człowieka (zob. Barrett, 2007). Część badaczy w tym nurcie upatruje psychologicznego podłoża religii w sferze funkcjonowania poznawczego człowieka, sugerując, że rozwój religijności może być swoistym produktem ubocznym pewnych naturalnie zachodzących procesów poznawczych (Willard, Norenzayan, 2013). Jednocześnie zwraca się też uwagę, iż sposób funkcjonowania poznawczego może stanowić ograniczenie dla religijności lub wyznaczać jej granice (np. Gervais, 2013).

Poza strukturami poznawczymi, które mogą w pewnym stopniu predysponować lub utrudniać rozwój religijności, badacze podkreślaja, iż kluczowa rolę w tym procesie odgrywają również zmienne o charakterze społeczno-emocjonalnym. Z jednej strony, mowa tu o przede wszystkim o różnorodnych procesach społecznego uczenia się religijności, które istotnie przyczyniają się do transgeneracyjnego przekazu religijności (zob. Lanman, Buhrmester, 2016). Z drugiej zaś strony, współczesne ujęcia sugerują także, iż znaczenie dla religijności maja pewne zdolności emocjonalne, które pełnią ważne funkcje zarówno z punktu widzenia indywidualnego, jak i wspólnotowego wymiaru religijności (por. Paek, 2006; Van Cappellen, Toth-Gauthier, Saroglou, Fredrickson, 2016).

Przedmiotem niniejszego opracowania będzie próba zwięzłego scharakteryzowania związków religijności z wybranymi zdolnościami poznawczymi i społeczno-emocjonalnymi. Omówione w tym kontekście zostaną zwłaszcza takie zmienne jak inteligencja poznawcza, inteligencja emocjonalna, mentalizacja oraz empatia emocjonalna.

\section{WIARA I ROZUM. RELIGIJNOŚĆ A ZDOLNOŚCI POZNAWCZE}

W kontekście zdolności poznawczych nietrudno zauważyć, że ludzie na ogół różnią się od siebie szybkością i efektywnością wykonywania zadań umysłowych. Istnienie tego rodzaju zmienności międzyosobniczej jest nie tylko podstawą potocznego rozumienia inteligencji, ale było także przedmiotem dociekań w psychologii niemal od początków jej samodzielnego istnienia (por. Nęcka, 2003). Co ciekawe, religijność - podobnie jak inteligencja - również szybko stała obiektem zainteresowania psychologii. W istocie prekursorem badań w zakresie obu tych zjawisk był już brytyjski uczony Francis Galton 
(1822-1911), który w swojej działalności zajmował się zagadnieniem osobowych uwarunkowań „geniuszu” (Galton, 1883, za: Nęcka, 2003), jak również badał skuteczność religijnego rytuału modlitwy (Galton, 1872, za: Wulff, 1999).

Zainteresowanie związkiem pomiędzy inteligencją a religijnością ma także dość długą tradycję w psychologii, a jego źródłem mogą być, prawdopodobnie sięgające już czasów starożytnych, rozważania na temat wzajemnych relacji pomiędzy wiarą a rozumem (fides et ratio; por. Plantinga, 1991). Pierwsze badania empiryczne łączące inteligencję $z$ religijnościa pojawiły się niemal 100 lat temu i wskazywały dość jednoznacznie, iż wyższy poziom inteligencji wiąże się z niższym poziomem religijności (Howells, 1928; Sinclair, 1928). W kolejnych latach następowała stopniowa kumulacja danych potwierdzających istnienie negatywnej zależności pomiędzy wiarą a inteligencja (por. Argyle, 1958; Francis, 1998), choć jednocześnie pojawiały się także pojedyncze doniesienia mówiące o braku związku pomiędzy dwoma zmiennymi (np. Francis, 1979). Co ciekawe, występowanie ujemnego związku pomiędzy inteligencją a wiarą odnotowano nie tylko na poziomie indywidualnym, ale także na poziomie grupowym. Badanie Lynna, Harveya i Nyborga (2009), obejmujące dane ze 137 krajów świata, wykazało, że związek pomiędzy średnim poziomem inteligencji ogólnej w danym kraju oraz wiara w Boga jest silnie negatywny (korelacja na poziomie $-0,60)$. Podobne dane, wskazujące na ujemną korelację inteligencji i religijności w obrębie 50 stanów USA, uzyskali zaś Pesta, McDaniel i Bertsch (2010), choć warto w tym miejscu zauważyć, że dane na temat IQ krajów bywają krytykowane (np. Wicherts, Dolan, van der Maas, 2010).

W związku z rosnąca na przestrzeni lat liczbą badań nad związkami religijności i inteligencji pojawiała się potrzeba uporządkowania dotychczasowego stanu wiedzy na temat tej zależności. Zadania tego podjęła się grupa amerykańskich badaczy z Mironem Zuckermanem na czele, którzy w 2013 roku opublikowali metaanalizę badań nad inteligencja poznawczą i religijnością uwzględniająca dane z 63 badań empirycznych przeprowadzonych na przestrzeni lat 1928-2012 (zob. Zuckerman, Silberman, Hall, 2013). W wyniku przeprowadzonej analizy stwierdzono, że istnieje istotny statystycznie, negatywny związek pomiędzy inteligencją a religijnościa, a siła tego związku oscyluje wokół wartości -0,24. Wykazano jednocześnie, że zależność ta jest silniejsza w grupie studentów i populacji ogólnej niż u młodzieży w wieku przedstudenckim, a także iż występuje ona w sposób bardziej systematyczny w przypadku przekonań religijnych niż praktyki religijnej. 
CO STOI ZA ZWIĄZKIEM INTELIGENCJI I RELIGIJNOŚCI? Poza ustaleniem ogólnego kierunku i siły zależności pomiędzy religijnością i inteligencją autorzy omawianej metaanalizy pokusili się również o próbę wyjaśnienia zaobserwowanego związku. Jedna z zaproponowanych interpretacji sugerowała, że osoby bardziej inteligentne charakteryzują się mniejszą skłonnością do podporządkowywania się, co może stać w konflikcie z potrzebą akceptacji dogmatów religijnych. Ponadto wykazano również, że inteligencja wiążę się pozytywnie z analitycznym sposobem myślenia (Frederick, 2005), który został już wcześniej zidentyfikowany jako czynnik utrudniający wiarę w Boga (Gervais, Norenzayan, 2012). Jak pokazuja dotychczasowe badania, analityczny styl przetwarzania informacji może stać w sprzeczności z intuicyjnym charakterem przekonań na temat istnienia bytów nadprzyrodzonych (Shenhav, Rand, Greene, 2012). Możliwe też wreszcie, że osoby inteligentne po prostu nie potrzebują religii, gdyż potrafia innymi środkami zaspokajać pewne potrzeby realizowane przez niektórych ludzi na płaszczyźnie religijnej (np. potrzebę bezpiecznej przynależności czy potrzebę poczucia kontroli nad własnym życiem; Zuckerman, Li, Lin, Hall, 2013). Jeszcze innym pojawiającym się w literaturze pomysłem na wyjaśnienie negatywnej korelacji między inteligencją a wiarą było przypuszczenie, że za tę zależność odpowiada trzeci czynnik, np. status społeczno-ekonomiczny (zob. Lewis, Ritchie, Bates, 2011). Oznaczałoby to, że zależność ta ma w istocie charakter pozorny i wynika z faktu, iz bardziej rozwinięte gospodarczo kraje charakteryzują się zazwyczaj wyższym poziomem inteligencji i jednocześnie wykazują na ogół dużo większy stopień sekularyzacji. Tego rodzaju przypuszczenia zostały jednak w dużej mierze zakwestionowane dzięki analizom wskazującym na istotne negatywne zależności między religią a narodowym IQ przy jednoczesnej kontroli poziomu rozwoju ekonomicznego w danym kraju (Cribari-Neto, Souza, 2013).

Przy wyjaśnieniu tego fenomenu istotna wydaje się również kategoria otwartości (openness), która jest dodatnio powiązana z inteligencja, a może także odpowiadać za częstszą skłonność do wybierania ewolucyjnego novum, jakim jest ateizm (Kanazawa, 2010). Kanazawa (2010) uważa, że to ateizm, w przeciwieństwie do religijności, jako pewna ewolucyjna nowość, jest częściej preferowany przez osoby o wyższej inteligencji ogólnej. Religia, zdaniem Kanazawy, powstała jako produkt uboczny skłonności do przypisywania intencjonalności różnorodnym zdarzeniom naturalnym (np. zjawiskom pogodowym czy chorobom) i, jako taka, sama nie posiada wartości adaptacyjnej, szczególnie w zmieniającym się dziś dynamicznie świecie (Kanazawa, 2010). Jednocześnie należy zauważyć, że otwartość na doświadczenie wykazuje bardziej skomplikowane 
związki z poszczególnymi aspektami religijności, np. pozytywne skorelowanie z duchowościa (spirituality), tj. nieinstytucjonalnym i osobistym ustosunkowaniem jednostki względem transcendencji, a negatywną zależność $z$ religijnym fundamentalizmem (religious fundamentalism), czyli literalną i bezwyjątkową interpretacją treści doktryny religijnej (Lewis i in., 2011).

ODBIÓR DOTYCHCZASOWYCH WYNIKÓW I NAJNOWSZE DONIESIENIA. Wyniki metaanalizy autorstwa Zuckermana $\mathrm{i}$ in. (2013) wzbudziły powszechne zainteresowanie opinii publicznej i odbiły się szerokim echem w świecie naukowym (ponad 250 cytowań wg Google Scholar, stan na dzień 15 grudnia 2020). Przedstawione przez autorów wnioski okazały się jednak dość kontrowersyjne. Trafność wyników omawianej metaanalizy została zakwestionowana przez Webstera i Duffy'ego (2016). W swojej publikacji na łamach prestiżowego czasopisma Intelligence przedstawili oni ponowną analizę danych zebranych przez Zuckermana i in. (2013), która wskazywała, że wnioskowana przez nich negatywna zależność pomiędzy inteligencją a religijnością zachodzi jedynie w przypadku kobiet oraz jedynie dla badań przeprowadzonych przed 2010 rokiem. Co więcej, Webster i Duffy (2016) przedstawili także szereg zastrzeżeń metodologicznych i statystycznych do pracy Zuckermana oraz wykazali, że omawiany związek inteligencji i religijności może być częściowo zależny od poziomu wykształcenia uczestników badania.

W odpowiedzi na przedstawione zarzuty Zuckerman wraz z grupa współpracowników przeprowadził w ostatnim czasie kolejną analizę oryginalnego zbioru 63 badań ze swojej metaanalizy uzupełnionego dodatkowo o 21 nowych badań opublikowanych w latach 2011-2018 (Zuckerman i in., 2020). Potwierdzono ponownie występowanie ujemnej korelacji pomiędzy inteligencja a religijnością (na poziomie od $-0,20$ do $-0,23$ ) zarówno w przypadku kobiet, jak i mężczyzn. Nie znaleziono także empirycznego potwierdzenia dla postulowanej przez Webstera i Duffy'ego mediacji poprzez poziom wykształcenia badanych. Wykazano zaś, że relacja inteligencji i religijności jest częściowo zapośredniczona poprzez analityczny styl myślenia. Ta swoista dyskusja pomiędzy badaczami pokazuje dobitnie, iż mimo swojej długiej historii zagadnienie powiązania inteligencji poznawczej i religijności jest wciąż tematem żywym. Dotychczasowe dane sugeruja, iż choć postulowana ujemna korelacja pomiędzy oboma konstruktami istnieje, to jest ona raczej niewielka i może zależeć od szeregu innych czynników. 


\section{WIARA A SERCE. RELIGIJNOŚĆ A ZDOLNOŚCI SPOŁECZNO- EMOCJONALNE}

Fakt, iż religijność i wysokie zdolności poznawcze mogą być jedynie słabo związane, skłonił badaczy do poszukiwania innych obszarów, w których osoby wierzące moga lokować swoje zasoby. Jak pokazują bowiem badania, osoby religijne nie tylko odznaczają się niższym poziomem inteligencji poznawczej, ale także na ogół nie cenią sobie wartości osobistych osiąnnięć (Saroglou, Delpierre, Dernelle, 2004). Zamiast tego preferują one wartości służące utrzymywaniu i wzmacnianiu satysfakcjonujących więzi społecznych, takie jak tradycja, przystosowanie czy życzliwość. Tego rodzaju preferencje wydają się zrozumiałe, zwłaszcza biorąc pod uwagę, iż religia jest zjawiskiem o charakterze społecznym i poza pewnymi aspektami indywidualnymi (np. przekonaniami religijnymi) obejmuje także istotny wymiar grupowy. W związku z tym część naukowców jest zdania, że osoby religijne zamiast „inwestować” w swój rozwój poznawczy, mogą być bardziej zainteresowane rozwojem społecznym, dla którego zaś istotne są przede wszystkim zdolności o charakterze emocjonalnym (Jack, Friedman, Boyatzis, Taylor, 2016).

Ujęcie takie może do pewnego stopnia odpowiadać popularnej opozycji pomiędzy „rozumem” a „sercem”, czy, innymi słowy, racjonalnością a uczuciami. W obliczu tak sformułowanego wyboru osoby religijne wydają się bardziej skłonne do podążania drogą emocji. Co ciekawe, ten potoczny pogląd jest spójny z tzw. hipotezą opozycyjnych systemów umysłu (opposing domains of mind hypothesis; Jack i in., 2016). Teoria ta głosi, iż analityczne i społeczno-emocjonalne aspekty umysłu pozostają w swoistej konkurencji wobec siebie, a stan ma swoje źródło już w budowie funkcjonalnej ludzkiego mózgu. Badania neuropsychologiczne wskazują bowiem na istnienie dwóch antagonistycznych szlaków neuronalnych - tzw. sieci zorientowanej na zadania (task-positive network), która wiąże się z kontrolą poznawczą i myśleniem analitycznym oraz tzw. sieć aktywności bazowej (default mode network), która zaangażowana jest, między innymi, w przetwarzanie bodźców emocjonalnych i społecznych (Jack $i$ in., 2013). Co ważne, udowodniono, że zwiększenie aktywności jednego z tych szlaków może prowadzić do dezaktywacji drugiego z nich. I tak, na przykład, Small, Loewenstein i Slovic (2007) odkryli, iż wzbudzenie u uczestników badania analitycznego stylu myślenia poprzez zaprezentowanie im pewnych problemów matematycznych prowadzi następnie do zmniejszenia reakcji empatycznej w odpowiedzi na historie osób znajdujących się w trudnej sytuacji życiowej. Co szczególnie interesujące, oba opozycyjne systemy umysłu wykazują też przeciwstawne związki z religijnością i wiarą w Boga. W serii głośnych 
eksperymentów Gervais i Norenzayan (2012) pokazali, iż nawet tak prosta manipulacja, jak zaprezentowanie badanym rzeźby Myśliciel autorstwa Augusta Rodina, której widok może skłaniać do myślenia analitycznego (w opozycji do rzeźby Dyskobol dłuta Myrona stanowiącej neutralny punkt odniesienia), potrafi doprowadzić do istotnego zmniejszenia deklarowanej wiary. Z drugiej strony, liczne dowody wskazują, że religia ma pozytywny związek ze zmiennymi o charakterze społeczno-emocjonalnym (Jack $i$ in., 2016). Najnowsze badania sugerują również, że same osoby religijne czują się, metaforycznie, bardziej związane z własnym ,sercem” niż z „głową” (Fetterman i in., 2020).

RELIGIJNOŚĆ A INTELIGENCJA EMOCJONALNA. Jeden $z$ ciekawych obszarów badań nad zdolnościami społeczno-emocjonalnymi osób religijnych dotyczy inteligencji emocjonalnej. Termin ,inteligencja emocjonalna”, który zyskał w ostatnim czasie duża popularność w psychologii, został pierwotnie zdefiniowany przez Saloveya i Mayera (1990). Autorzy ci zaproponowali, poprzez analogię do inteligencji poznawczej, iż inteligencja emocjonalna może być rozumiana jako zbiór zdolności poznawczych służących przetwarzaniu informacji o charakterze emocjonalnym. Na tę globalną zdolność emocjonalną, zdaniem Mayera i Saloveya (1997), składaja się cztery hierarchicznie ułożone grupy zdolności: rozpoznawanie emocji, wykorzystanie emocji (w celu usprawnienia myślenia), rozumienie emocji i zarządzanie emocjami. Takie ujęcie inteligencji emocjonalnej nie jest jednak jedynym możliwym rozumieniem tego konstruktu. Poza przytoczonym modelem zdolnościowym rozpowszechnione jest również ujęcie inteligencji emocjonalnej jako cechy osobowości. Zwolennikami takiego poglądu są m.in. Petrides i Furnham (2001). Według tych autorów inteligencja emocjonalna to swoiste poczucie skuteczności emocjonalnej, które ma charakter trwałej dyspozycji i może być badane samoopisowo (Petrides, Furnham, 2001).

Choć w świetle teorii opozycyjnych systemów umysłu uzasadnione wydaje się przypuszczenie, iż inteligencja emocjonalna, będąca konstruktem o adaptacyjnym, społecznym charakterze, może pozytywnie wiązać się z religijnościa, to jednak w chwili obecnej dowody empiryczne wskazujące na związki obu zmiennych są dość skromne. Jedno z pierwszych badań dotyczących tego zagadnienia wykazało, że inteligencja emocjonalna mierzona samoopisowo wiązała się dodatnio z pewnymi behawioralnymi wskaźnikami religijności oraz z wewnętrzną orientacją religijna, czyli traktowaniem religijności jako celu samego w sobie (Paek, 2006). W innej pracy również potwierdzono, że wyższa inteligencja emocjonalna jako cecha wiąże się z większym nasileniem religijnej 
orientacji wewnętrznej (Liu, 2010). Przedstawione badania przyniosły wstępne rozstrzygnięcia na temat powiązania religijności i inteligencji emocjonalnej, choć należy zwrócić uwagę, że w obu przypadkach inteligencja emocjonalna była tutaj rozumiana jako cecha i badana samoopisowo przy pomocy kwestionariuszy.

W badaniach własnych przeprowadzonych na grupie polskich dorosłych wykazaliśmy zaś, że większa religijność wiąże się także z wyższym poziomem rzeczywistych zdolności z zakresu inteligencji emocjonalnej (Lowicki, Zajenkowski, 2017a). Co więcej, w tej samej pracy pokazaliśmy, iż inteligencja emocjonalna (zarówno w ujęciu zdolnościowym, jak i cechowym) wiąże się negatywnie z zewnętrzną orientacją religijna (tj. instrumentalnym traktowaniem religijności) oraz negatywnym stylem religijnego radzenia sobie (religious coping). Może to oznaczać, iż wyższy poziom inteligencji emocjonalnej stanowi de facto czynnik chroniący przed rozwojem negatywnych i nieadaptacyjnych form religijności. W pewnej sprzeczności z przywołanymi danymi stoją zaś niedawne wyniki badań ze Stanów Zjednoczonych. Vonk i Pitzen (2017) zbadały związki inteligencji emocjonalnej w ujęciu zdolnościowym z różnymi miarami religijności i wykazały, że obie zmienne nie sa istotnie skorelowane.

W związku z zaobserwowaną niespójnością wyników w tym zakresie, w kolejnej serii badań własnych dokonaliśmy bezpośredniego porównania związku inteligencji poznawczej i emocjonalnej z religijnością (Lowicki, Zajenkowski, van der Linden, 2020). Wyniki tych dociekań pokazały, że pomiędzy inteligencja poznawczą a emocjonalną w kontekście religijności dochodzić może do zjawiska supresji, czyli wzajemnego tłumienia swojego wpływu. W szczególności zaś stwierdziliśmy, iż choć inteligencja emocjonalna nie wykazała początkowo istotnego powiązania z religijnościa, to kontrola poziomu inteligencji poznawczej osób badanych doprowadziła do uzyskania istotnego i pozytywnego związku pomiędzy inteligencją emocjonalną a religijnością (Lowicki, Zajenkowski, van der Linden, 2020). Pomimo iż siła tego efektu nie była duża i wystapił on jedynie w przypadku niektórych miar religijności, to jednak wynik ten może wskazywać na bardziej złożony charakter samej inteligencji emocjonalnej. Należy bowiem zauważyć, że jako zdolność poznawcz̧a dotycząca emocji, inteligencja emocjonalna może łączyć różne komponenty, które wykazują odmienne relacje z wiarą. I tak na przykład elementy „zimnego”, analitycznego przetwarzania bodźców o charakterze emocjonalnym mogą łączyć się z religijnością w sposób podobny do inteligencji poznawczej czy analitycznego stylu myślenia. Możliwe jednak, że inteligencja emocjonalna zawiera w sobie również komponenty o charakterze bardziej intuicyjnym czy emocjonalnym (np. 
takie zbliżone do empatii emocjonalnej; por. Mayer, DiPaolo, Salovey, 1990), które z kolei mogą wykazywać pozytywne powiązanie z wiarą i religijnością (por. Jack i in., 2016).

Możliwe mechanizmy łączące inteligencję emocjonalną z religijnością nie zostały dziś jeszcze w pełni poznane. Dotychczasowe wyjaśnienia sugeruja między innymi, iż wspólnoty religijne moga działać jak swoiste organizacje inteligentne emocjonalnie, które poprzez zweryfikowane i utrwalone w tradycji sposoby ułatwiają swoim członkom skuteczną regulację emocji (Pizarro, Salovey, 2002). Dla przykładu rytuał modlitwy, medytacja czy spowiedź poza swoja rolą religijną mogą także pełnić funkcję o charakterze emocjonalnym, gdyż pozwalają na bardziej efektywne radzenie sobie z własnymi uczuciami. W takim ujęciu bycie częścią wspólnoty religijnej i praktykowanie religii mogłoby w dłuższej perspektywie przyczyniać się do istotnego zwiększenia inteligencji emocjonalnej wiernych. Z innego punktu widzenia można również zakładać, że rozwój inteligencji emocjonalnej poprzedza kształtowanie się dojrzałej postawy wobec religijności. Zgodnie z dostępnymi danymi empirycznymi, wydaje się możliwe, że wysoki poziom zdolności o charakterze emocjonalnym może chronić przed rozwinięciem nieadaptacyjnych form wiary (por. Lowicki, Zajenkowski, 2017a).

RELIGIJNOŚĆ A MENTALIZACJA. Stosunkowo nowym nurtem w poszukiwaniach psychologicznego podłoża religijności jest powiązanie jej z „mentalizacją" (mentalizing; Willard, Norenzayan, 2013), czyli umiejętnością wnioskowania o stanach mentalnych innych ludzi (np. myślach, emocjach, intencjach czy życzeniach). Zdolność ta, określana też niekiedy mianem teorii umysłu (theory of mind; Frith, Frith, 2005), jest powszechnie postrzegana jako znaczące osiagnięcie rozwojowe umożliwiające człowiekowi funkcjonowanie w złożonej rzeczywistości społecznej (Flavell, 1999). Co istotne, atrybucja umysłów nie ogranicza się jednak bynajmniej do ludzi. Niekiedy przypisujemy pewne stany mentalne zwierzętom (Waytz, Gray, Epley, Wegner, 2010) czy nawet obiektom nieożywionym (Stafford, MacDonald, Jayawardena, Wegner, Broadbent, 2014), a wielu ludzi wierzy ponadto $\mathrm{w}$ istnienie różnego rodzaju nadprzyrodzonych bytów (np. bóstw, duchów), którym także przypisywane są, analogiczne do ludzkich, myśli i emocje (Gervais, 2013). W związku z tym, zdolność do mentalizacji jest obecnie postrzegana jako warunek konieczny dla rozwoju mentalnych reprezentacji bóstw, a co za tym idzie - wiary religijnej w ogóle (Gervais, 2013; Willard, Norenzayan, 2013). 
Co ciekawe, badania empiryczne wykazały, że myślenie o Bogu wywołuje identyczne skutki, co myślenie o innych ludziach np. w kontekście zwiększenia motywacji prospołecznej. Może to stanowić pewien pośredni dowód związku pomiędzy mentalizacją a wiarą (Gervais, 2013; Shariff, Norenzayan, 2007). Istotnych danych na temat powiązania mentalizacji z religijnością dostarczaja także badania nad autyzmem. To złożone zaburzenie rozwojowe charakteryzuje się różnorodnymi trudnościami w funkcjonowaniu społecznym i jest powszechnie łączone z deficytami w zdolnościach do mentalizacji, określanymi niekiedy mianem ,ślepoty na umysły” (mindblindness; Baron-Cohen, 1997). Jak pokazują badania, osoby z zaburzeniami autystycznymi deklarują mniejsza wiarę w Boga, a wynik ten jest w pełni zapośredniczony poprzez ich trudności w zakresie teorii umysłu (Norenzayan, Gervais, Trzesniewski, 2012). Może to wskazywać, iż posiadanie co najmniej pewnego stopnia umiejętności mentalizacji jest niezbędne do rozwoju intuicyjnego przekonania o istnieniu bytów nadprzyrodzonych. Wreszcie również badania oparte na neuroobrazowaniu potwierdziły, że zarówno myślenie o Bogu, jak i modlitwa, aktywują te same struktury mózgowe, które zostały wcześniej zidentyfikowane jako neuronalne podłoże społecznego poznania i teorii umysłu (Kapogiannis i in., 2009; Schjoedt, Stødkilde-Jørgensen, Geertz, Roepstorff, 2009).

Mimo przytoczonych powyżej argumentów należy odnotować, że zależność pomiędzy religijnością a mentalizacją nie jest w pełni jednoznaczna, a wyniki najnowszych badań w tym zakresie wskazuja, że obie zmienne mogą nie być w rzeczywistości istotnie powiązane (Maij i in., 2017) lub że zależność pomiędzy nimi może mieć charakter negatywny (Vonk, Pitzen, 2017). Niespójność danych empirycznych w tym zakresie może mieć kilka przyczyn. Po pierwsze, stan ten może częściowo wynikać z niedostatecznego uwzględnienia przez autorów problemu metapercepcji własnych zdolności (Realo i in., 2003; Willard, Norenzayan, 2013). Mentalizacja była dotąd badana zarówno jako rzeczywista zdolność w zakresie wnioskowania o stanach mentalnych innych ludzi (np. Norenzayan i in., 2012), jak również jako samoopisowa dyspozycja, tzn. swoista tendencja do częstszego metalizowania (np. Maij i in., 2017; Willard, Norenzayan, 2013). Ostatnie dane wskazują zaś, iż osoby religijne mogą mieć skłonność do częstszego wnioskowania o myślach i uczuciach, choć nie oznacza to, że robia to one skuteczniej czy trafniej niż inni (Vonk, Pitzen, 2017). Możliwe ponadto, że omawiany związek wiary i zdolności mentalizacyjnych ma charakter krzywoliniowy. Jakkolwiek bowiem pewien poziom umiejętności postrzegania umysłów wydaje się konieczny, aby tworzyć reprezentacje mentalne bóstw, to jednak osoby o bardzo wysokich kompetencjach mentalizacyjnych 
mogą być również bardziej sceptyczne wobec przypisywania stanów mentalnych bytom nadprzyrodzonym (Vonk, Pitzen, 2017). Niewykluczone także, że powyżej pewnego progu zdolności mentalizacji potrzebnego dla rozwoju religijności nie występuje już znaczące zróżnicowanie między osobami w tym zakresie (por. Reddish, Tok, Kundt, 2016).

Najnowsze badania własne dotyczące religijności i mentalizacji, które uwzględniały zarówno pomiar rzeczywistych zdolności, jak i metody samoopisowe, potwierdziły pojawiające się w ostatnim czasie przypuszczenia, iż obie zmienne nie są istotnie powiązane lub ich związki mają charakter negatywny (Lowicki, Zajenkowski, Van Cappellen, 2020). W odniesieniu do jednej z często stosowanych miar rzeczywistych zdolności mentalizacji wykazaliśmy ponadto, iż jej powiązanie z ogólną religijnością może być w dużym stopniu zależne od poznawczego stylu religijności, którym odznaczają się osoby badane. W ujęciu tym rozróżniono literalne (tj. dosłowne) i symboliczne traktowanie treści religijnych, niezależnie od stopnia ich akceptacji czy odrzucenia. Uwzględnienie poznawczego sposobu przetwarzania dogmatów wiary pokazało, iż osoby o wysokim poziomie zdolności mentalizacyjnych dużo częściej posługują się symboliczną interpretacją religii. Jednocześnie osoby te wykazują się również większym poziomem niewiary religijnej, tj. odrzucania dogmatów religijnych (Lowicki, Zajenkowski, Van Cappellen, 2020). Obserwacja ta może częściowo tłumaczyć rozbieżności w literaturze przedmiotu dotyczące potencjalnych związków mentalizacji i religijności. Proporcja wyznawców, którzy wierzą w sposób literalny lub symboliczny może bowiem istotnie różnić się w zależności od tego, w jakim kontekście kulturowym i na jakiej grupie przeprowadzane jest badanie (zob. Hunsberger, Owusu, Duck, 1999), a to w efekcie skutkować może odmiennymi powiązaniami ogólnej religijności z mentalizacja.

Dodatkowo w przytoczonych badaniach własnych wykazaliśmy również, że popularne narzędzie kwestionariuszowe, które używane było dotychczas jako miara tendencji mentalizacyjnych, może w rzeczywistości wiązać się z religijnością za sprawą swoich komponentów emocjonalnych, które są blisko związane z innym konstruktem, tj. empatią emocjonalną (Lowicki, Zajenkowski, Van Cappellen, 2020). Podobnie jak w przypadku inteligencji emocjonalnej, wynik ten może zatem sugerować, iż mentalizacja w swoim wymiarze poznawczym nie jest w istocie pozytywnie skorelowana $z$ religijnością. Znaczenie empatii emocjonalnej dla religijności zostanie przedstawione w kolejnym podrozdziale. 


\section{RELIGIJNOŚĆ A EMPATIA EMOCJONALNA}

Choć brakuje powszechnego konsensu w kwestii definicji terminu „empatia”, można jednak przyjąć, iż mianem tym określa się zazwyczaj proces o charakterze afektywnym, który polega na współdzieleniu lub „rezonowaniu” z emocjami innej osoby (zob. Davis, 1999; Singer, Lamm, 2009). Jako taka, empatia, nie jest zatem tożsama z mentalizacją, która w typowym ujęciu opiera się na poznnawç̊ym wnioskowaniu na temat stanów mentalnych innych ludzi. Mimo pozornej zbieżności obu terminów należy zauważyć, iż są to zjawiska rozłączne, które nie muszą współwystępować. Dla przykładu „zimna” zdolność mentalizacji może być potrzebna w trakcie negocjacji biznesowych, gdy zależy nam na odgadnięciu stanu mentalnego drugiej osoby (por. Epley, Caruso, Bazerman, 2006). Jednocześnie można się spodziewać, że w takiej sytuacji partnerzy negocjacyjni nie musza (a być może nawet nie powinni) angażować empatii, czyli współodczuwania z drugą stroną. Co więcej, dobrym przykładem na dysocjację obu zjawisk są również zaburzenia ze spektrum autyzmu oraz psychopatia. Jak wcześniej wspomniano, osoby z zaburzeniami autystycznymi przejawiaja wyraźne deficyty w zakresie teorii umysłu (Baron-Cohen, 1997), ale jednocześnie nie odnotowuje się u nich większych trudności z empatią emocjonalna (Bird i in., 2010). W zburzeniach osobowości o rysie psychopatycznym czy nawet subklinicznej psychopatii rozumianej jako cecha osobowości mamy zaś często do czynienia ze skrajnym brakiem empatii emocjonalnej (Blair, 2008; Lowicki, Zajenkowski, 2017b), choć badania pokazuja jednocześnie, że te osoby są w stanie wnioskować o stanach mentalnych równie dobrze, co inni ludzie (Richell i in., 2003).

Idąc jeszcze dalej, należy wskazać, że empatia jako proces współdzielenia emocji drugiego człowieka (w tym najczęściej emocji o charakterze negatywnym) może doprowadzić do wystąpienia dwóch alternatywnych następstw. Po pierwsze, pobudzenie empatyczne może skutkować pojawieniem się tzw. empatycznej troski (empathic concern; zob. Davis, 1999; Jack i in., 2016), czyli zorientowanej na innych skłonności do współczucia (compassion). Alternatywnie, doświadczenie empatii może także prowadzić do wystąpienia tzw. osobistej przykrości (personal distress; zob. Davis, 1999; Singer, Lamm, 2009), czyli zorientowanych na siebie uczuć w rodzaju strachu, niepokoju, dyskomfortu czy przykrości. To szczegółowe rozróżnienie jest istotne z punktu widzenia badań nad religijnością, gdyż najnowsze doniesienia sugerują, iż wyłącznie jeden rodzaj empatii - empatyczna troska - wykazuje pozytywne i systematyczne powiązanie $z$ wiara (por. Jack i in., 2016). 
Dotychczasowe dowody na związek empatii emocjonalnej, w szczególności zaś empatycznej troski, i religijności maja głównie charakter doniesień korelacyjnych. Na przykład w jednym z wczesnych badań Watson, Hood, Morris i Hall (1984) wykazali, że osoby o wewnętrznej orientacji religijnej, tj. traktujące religię jako cel sam w sobie, deklarowały większą empatię rozumianą jako odczuwana reakcja emocjonalna oraz jako poczucie podobieństwa do innych ludzi. Znaczenie empatii dla wiary religijnej wykazaliśmy także w dotychczasowych badaniach własnych (Lowicki, Zajenkowski, 2017b). Pokazaliśmy wówczas, że osoby odznaczające się wysokim nasileniem negatywnych cech osobowości (tj. psychopatii i makiawelizmu) deklarują mniejszą wiarę w Boga, a efekt może być częściowo zależny od występujących u nich deficytów empatii (Lowicki, Zajenkowski, 2017b). W ostatnim czasie stwierdzono także, że w trakcie ekstremalnych praktyk religijnych wiążących się z zadawaniem sobie bólu dochodzi do synchronizacji empatycznej w zakresie odczuwanego bólu pomiędzy aktywnymi uczestnikami rytuału a osobami obserwującymi ten akt (Xygalatas i in. 2013).

Jakie mechanizmy stoja za związkiem empatii emocjonalnej oraz religijności? Na poziomie teoretycznym badacze sugerowali zazwyczaj, iż religie wraz ze swoimi systemami aksjologicznymi i jasnymi kodeksami moralnymi moga wzmacniać skłonność do współodczuwania z drugim człowiekiem (np. Hardy, Walker, Rackham, Olsen, 2012; Markstrom, Huey, Stiles, Krause, 2010). W ostatnim czasie zauważono ponadto, iż empatyczna troska jest tzw. emocja samotranscendentną (self-transcendent, por. Stellar i in., 2017), co oznacza, iż nakierowuje ona człowieka ,na zewnątrz” i prowadzi do zwrócenia uwagi na innych ludzi (w tym przypadku zaś zwłaszcza na cierpienie drugiej osoby). Jak się wydaje, mechanizm ten może również pośrednio przyczyniać się do zwiększenia duchowości czy religijności, które w swojej istocie zakładaja zwrócenie się człowieka „na zewnątrz”, ku rzeczywistości nadprzyrodzonej. Należy jednak stwierdzić, iż argumenty te maja jedynie charakter spekulatywny, gdyż przy obecnym stanie wiedzy brakuje badań, które mogłyby zidentyfikować czynniki stojące za pozytywną zależnością empatii i wiary. Co więcej, na obecnym etapie dociekań badawczych wciąż niewiele wiadomo także na temat powiazań empatii z innym zmiennymi ważnymi dla rozwoju religijności.

Pierwsze dane empiryczne w tym zakresie przyniosło jedno z niedawno zrealizowanych badań własnych (Lowicki, Zajenkowski, 2020). Dociekanie to służyło bezpośredniemu porównaniu roli empatii emocjonalnej oraz procesów społecznego uczenia się w rozwoju indywidualnej religijności. W przeprowadzonym badaniu wykazaliśmy, że w przypadku większości analizowanych 
wymiarów religijności są one pozytywnie przewidywane zarówno poprzez indywidualny poziom empatii emocjonalnej, jak i retrospektywnie oceniane doświadczenia z wiarygodną religijnością rodziców czy opiekunów. Wyjątkiem w tym przypadku okazała się jedynie publiczna praktyka religijna. Deklarowana częstość uczestnictwa w nabożeństwach była istotnie przewidywana tylko poprzez doświadczenia z okresu dzieciństwa. Wyniki przeprowadzonego badania sugerują, że bycie religijnym może zależeć zarówno od społecznego uczenia się w kontekście rodzinnym, jak i, częściowo, od osobowościowych predyspozycji w zakresie empatii (Łowicki, Zajenkowski, 2020).

Choć przytoczone powyżej dane wskazują na dość silne, systematyczne i pozytywne powiązanie religijności i empatii, to nie są one jednak wolne od pewnych ograniczeń. W szczególności stosowane miary empatii emocjonalnej mają niemal wyłącznie charakter samoopisowy, co czyni je podatnymi na zniekształcenia wynikające z potrzeby aprobaty społecznej (Sedikides, Gebauer, 2010). Ponadto niektórzy autorzy sugeruja, że pozytywne korelacje wskaźników wiary z empatią mogą być jedynie efektem mniej lub bardziej świadomej tendencji do autoprezentacji czy zafałszowanego obrazu własnej osoby (np. Saroglou, Pichon, Trompette, Verschueren, Dernelle, 2005). W celu weryfikacji tych zastrzeżeń przeprowadzono dotychczas szereg badań łączących empatię z religijnością przy uwzględnieniu potrzeby aprobaty społecznej (np. Saroglou $\mathrm{i}$ in., 2005; Watson i in., 1984). Co ciekawe, badania te zgodnie wykazały, iż omawiana zależność utrzymywała się niezależnie od poziomu kontrolowanej aprobaty społecznej.

Aby dodatkowo zweryfikować przypuszczenie, iż deklarowany poziom empatii może nie odpowiadać rzeczywistej skłonności osób religijnych, przeprowadzono badanie własne, które poza miarami samoopisowymi uwzględniało również szacowanie empatii oraz religijności przez bliskich uczestników badania (np. partnerów, przyjaciół, rodziców itp.). Wykazaliśmy wówczas, iż osoby bardziej religijne deklaruja większą empatyczną troskę, a jednocześnie są także oceniane jako bardziej empatyczne przez swoich bliskich (Łowicki, Zajenkowski, 2019). W oczywisty sposób perspektywa osób bliskich może również być podatna na zniekształcenia, ale wyniki te sugerują, iż przynajmniej dwa niezależne źródła danych mogą potwierdzać wyższą empatię emocjonalną osób religijnych. Przyszłe badania w tym zakresie powinny jednak, z pewnością, wyjść poza schemat korelacyjny i uwzględnić możliwość eksperymentalnego oddziaływania pomiędzy empatią a religijnością, a także wykorzystać bardziej obiektywne miary empatii, jak np. wskaźniki psychofizjologicznej reakcji współczucia (por. Stellar, Cohen, Oveis, Keltner, 2015). 


\section{PODSUMOWANIE}

W ramach niniejszego opracowania prześledzono związki zdolności poznawczych i społeczno-emocjonalnych z religijnością i wiarą w Boga. Przeprowadzona analiza prowadzi do ogólnego wniosku, iż w ramach metaforycznej opozycji „rozumu” i ,serca” osoby religijne sytuują się raczej po stronie serca, czyli zdolności emocjonalnych i społecznych.

Przytoczone dane dotyczące związków inteligencji poznawczej i religijności wskazały na występowanie dość słabej negatywnej zależności pomiędzy dwoma zmiennymi. W przypadku zmiennych o charakterze społeczno-emocjonalnym dane empiryczne były zaś jeszcze mniej jednoznaczne. Zaprezentowano doniesienia wskazujące, iż wyższy poziom wiary może wiązać się z większymi zdolnościami w zakresie inteligencji emocjonalnej, choć przedstawiono również dane stojące w sprzeczności z tymi wynikami. Brak spójności można również zarzucić doniesieniom na temat związków mentalizacji i religijności. Spośród omawianych zmiennych społeczno-emocjonalnych najbardziej systematyczne i pozytywne powiązanie z religijnością wykazała zaś empatia emocjonalna. Co istotne, przedstawiono pewne argumenty sugerujące, że zmienne takie jak inteligencja emocjonalna czy mentalizacja mogą nie wiązać się istotnie z religijnością o tyle, o ile uwzględniamy ich aspekt poznawczy i analityczny. Jeśli zaś weźmiemy pod uwagę obecne w nich komponenty o charakterze emocjonalnym, związane bliżej z intuicyjnym i empatycznym przetwarzaniem, to mogą one wciąż wykazywać pozytywne relacje $z$ wiara.

\section{BIBLIOGRAFIA}

Allport, G. W., Ross, J. M. (1967). Personal religious orientation and prejudice. Journal of Personality and Social Psychology, 5, 432-443. https://doi.org/10.1037/h0021212 Argyle, M. (1958). Religious behaviour. Londyn: Routledge.

Atran, S., Norenzayan, A. (2004). Religion's evolutionary landscape: Counterintuition, commitment, compassion, communion. Behavioral \& Brain Science, 27(6), 713-770. https://doi.org/10.1017/S0140525X04000172

Baron-Cohen, S. (1997). Mindblindness: An essay on autism and theory of mind. Cambridge: The MIT Press.

Barrett, J. L. (2007). Cognitive science of religion: What is it and why is it? Religion Compass, 1(6), 768-786. https://doi.org/10.1111/j.1749-8171.2007.00042.x

Bird, G., Silani, G., Brindley, R., White, S., Frith, U., Singer, T. (2010). Empathic brain responses in insula are modulated by levels of alexithymia but not autism. Brain, 133(5), 1515-1525. https://doi.org/10.1093/brain/awq060 
Blair, R. J. R. (2008). Fine cuts of empathy and the amygdala: Dissociable deficits in psychopathy and autism. The Quarterly Journal of Experimental Psychology, 61(1), 157-170. https://doi.org/10.1080/17470210701508855

Cribari-Neto, F., Souza, T. C. (2013). Religious belief and intelligence: Worldwide evidence. Intelligence, 41(5), 482-489. https://doi.org/10.1016/j.intell.2013.06.011

Davis, M. H. (1999). Empatia. O umiejętności współodczuwania. Gdańsk: Gdańskie Wydawnictwo Psychologiczne.

Epley, N., Caruso, E. M., Bazerman, M. H. (2006). When perspective taking increases taking: Reactive egoism in social interaction. Journal of Personality and Social Psychology, 91(5), 872-889. https://doi.org/10.1037/0022-3514.91.5.872

Fetterman, A. K., Juhl, J., Meier, B. P., Abeyta, A., Routledge, C., Robinson, M. D. (2020). The path to God is through the heart: Metaphoric self-location as a predictor of religiosity. Self and Identity, 19(6), 650-672. https://doi.org/10.1080/15 298868.2019.1651389

Flavell, J. H. (1999). Cognitive development: Children's knowledge about the mind. Annual Review of Psychology, 50(1), 21-45. https://doi.org/10.1146/annurev. psych.50.1.21

Francis, L. J. (1979). School influence and pupil attitude towards religion. British Journal of Educational Psychology, 49(2), 107-123. https:// doi. org/10.1111/j.2044-8279.1979.tb02405.x

Francis, L. J. (1998). The relationship between intelligence and religiosity among 15-16-year-olds. Mental Health, Religion and Culture, 1(2), 185-196. https://doi. org/10.1080/13674679808406508

Frederick, S. (2005). Cognitive reflection and decision making. Journal of Economic Perspectives, 19(4), 25-42. https://doi.org/10.1257/089533005775196732

Frith, C., Frith, U. (2005). Theory of mind. Current Biology, 15(17), R644-R645. https://doi.org/10.1016/j.cub.2005.08.041

Gervais, W. M. (2013). Perceiving minds and gods: How mind perception enables, constrains, and is triggered by belief in gods. Perspectives on Psychological Science, 8(4), 380-394. https://doi.org/10.1177/1745691613489836

Gervais, W. M., Norenzayan, A. (2012). Analytic thinking promotes religious disbelief. Science, 336(6080), 493-496. https://doi.org/10.1126/science.1215647

Hardy, S. A., Walker, L. J., Rackham, D. D., Olsen, J. A. (2012). Religiosity and adolescent empathy and aggression: The mediating role of moral identity. Psychology of Religion and Spirituality, 4(3), 237-248. https://doi.org/10.1037/a0027566

Howells, T. H. (1928). A comparative study of those who accept as against those who reject religious authority. University of Iowa Studies in Character, 2, 1-80. 
Huber, S., Huber, O. W. (2012). The centrality of religiosity scale (CRS). Religions, 3(3), 710-724. https://doi.org/10.3390/rel3030710

Hunsberger, B., Owusu, V., Duck, R. (1999). Religion and prejudice in Ghana and Canada: Religious fundamentalism, right-wing authoritarianism and attitudes toward homosexuals and women. The International Journal for the Psychology of Religion, 9(3), 181-194. https://doi.org/10.1207/s15327582ijpr0903_2

Jack, A. I., Dawson, A. J., Begany, K. L., Leckie, R. L., Barry, K. P., Ciccia, A. H., Snyder, A. Z. (2013). fMRI reveals reciprocal inhibition between social and physical cognitive domains. NeuroImage, 66, 385-401. https://doi.org/10.1016/j.neuroimage.2012.10.061

Jack, A. I., Friedman, J. P., Boyatzis, R. E., Taylor, S. N. (2016). Why do you believe in God? Relationships between religious belief, analytic thinking, mentalizing and moral concern. PLoS One, 11(3), e0149989. https://doi.org/10.1371/journal. pone.0149989

Kanazawa, S. (2010). Why liberals and atheists are more intelligent. Social Psychology Quarterly, 73(1), 33-57. https://doi.org/10.1177/0190272510361602

Kapogiannis, D., Barbey, A. K., Su, M., Zamboni, G., Krueger, F., Grafman, J. (2009). Cognitive and neural foundations of religious belief. Proceedings of the National Academy of Sciences, 106(12), 4876-4881. https://doi.org/10.1073/pnas.0811717106

Lanman, J. A., Buhrmester, M. D. (2017). Religious actions speak louder than words: Exposure to credibility-enhancing displays predicts theism. Religion, Brain \& Behavior, 7(1), 3-16. https://doi.org/10.1080/2153599X.2015.1117011

Lewis, G. J., Ritchie, S. J., Bates, T. C. (2011). The relationship between intelligence and multiple domains of religious belief: Evidence from a large adult US sample. Intelligence, 39(6), 468-472. https://doi.org/10.1016/j.intell.2011.08.002

Liu, C. C. (2010). The relationship between personal religious orientation and emotional intelligence. Social Behavior and Personality: An International Journal, 38(4), 461467. https://doi.org/10.2224/sbp.2010.38.4.461

L'Osservatore Romano (2013). Free thought. Morning meditation in the Chapel of Domus Sanctae Marthae by Pope Francis. Pobrane z: http://www.vatican.va/content/francesco/en/cotidie/2013/documents/papa-francesco-cotidie_20131129_free-thought. $\mathrm{html}$

Lynn, R., Harvey, J., Nyborg, H. (2009). Average intelligence predicts atheism rates across 137 nations. Intelligence, 37(1), 11-15. https://doi.org/10.1016/j.intell.2008.03.004

Łowicki, P., Zajenkowski, M. (2017a). Divine emotions: On the link between emotional intelligence and religious belief. Journal of Religion \& Health, 56, 1998-2009. https://doi.org/10.1007/s10943-016-0335-3 
Lowicki, P., Zajenkowski, M. (2017b). No empathy for people nor for God: The relationship between the Dark Triad, religiosity and empathy. Personality and Individual Differences, 115, 169-173. https://doi.org/10.1016/j.paid.2016.02.012

Łowicki, P., Zajenkowski, M. (2019). Religiousness is associated with higher empathic concern: Evidence from self- and other-ratings. Psychology of Religion and Spirituality. Advance online publication. https://doi.org/10.1037/rel0000299

Łowicki, P., Zajenkowski, M. (2020). Empathy and exposure to credible religious acts during childhood independently predict religiosity. The International Journal for the Psychology of Religion, 30(2), 128-141. https://doi.org/10.1080/10508619.2019.16 72486

Lowicki, P., Zajenkowski M., Van Cappellen, P. (2020). It's the heart that matters: The relationships among cognitive mentalizing ability, emotional empathy, and religiosity. Personality and Individual Differences, 161, 109976. https://doi.org/10.1016/j. paid.2020.109976

Łowicki, P., Zajenkowski, M., van der Linden, D. (2020). The interplay between cognitive intelligence, ability emotional intelligence, and religiosity. Journal of Religion \& Health, 59, 2556-2576. https://doi.org/10.1007/s10943-019-00953-0

Maij, D. L., van Harreveld, F., Gervais, W., Schrag, Y., Mohr, C., van Elk, M. (2017). Mentalizing skills do not differentiate believers from non-believers, but credibility enhancing displays do. PLoS One, 12(8). https://doi.org/10.1371/journal. pone. 0182764

Markstrom, C. A., Huey, E., Stiles, B. M., Krause, A. L. (2010). Frameworks of caring and helping in adolescence: Are empathy, religiosity, and spirituality related constructs? Youth \& Society, 42(1), 59-80. https:/ / doi.org/10.1177/0044118X09333644

Mayer, J. D., DiPaolo, M., Salovey, P. (1990). Perceiving affective content in ambiguous visual stimuli: A component of emotional intelligence. Journal of Personality Assessment, 54(3-4), 772-781. https://doi.org/10.1080/00223891.1990.9674037

Mayer, J. D., Salovey, P. (1997). What is emotional intelligence? W: P. Salovey, D. J. Sluyter (red.), Emotional development and emotional intelligence: Educational implications (s. 3-31). Nowy Jork: Basic Books.

Nęcka, E. (2003). Inteligencja. Geneza. Struktura. Funkecje. Gdańsk: Gdańskie Wydawnictwo Psychologiczne.

Norenzayan, A., Gervais, W. M., Trzesniewski, K. H. (2012). Mentalizing deficits constrain belief in a personal God. PLoS One, 7(5), e36880. https://doi.org/10.1371/ journal.pone.0036880

Paek, E. (2006). Religiosity and perceived emotional intelligence among Christians. Personality and Individual Differences, 41(3), 479-490. https://doi.org/10.1016/j. paid.2006.01.016 
Pesta, B. J., McDaniel, M. A., Bertsch, S. (2010). Toward an index of well-being for the fifty US states. Intelligence, 38(1), 160-168. https://doi.org/10.1016/j.intell.2009.09.006

Petrides, K. V., Furnham, A. (2001). Trait emotional intelligence: Psychometric investigation with reference to established trait taxonomies. European Journal of Personality, 15(6), 425-448. https://doi.org/10.1002/per.416

Pew Research Center (2017). The Changing Global Religious Landscape. Pobrane z: https://www.pewforum.org/2017/04/05/the-changing-global-religious-landscape/

Pizarro, D., Salovey, P. (2002). Religious systems as „Emotionally Intelligent” organizations. Psychological Inquiry, 13(3), 220-222.

Plantinga, A. (1991). When faith and reason clash: Evolution and the Bible. W: D. L. Hull, M. Ruse (red.), The philosophy of biology (s. 674-697). Oxford: Oxford University Press.

Realo, A., Allik, J., Nõlvak, A., Valk, R., Ruus, T., Schmidt, M., Eilola, T. (2003). Mind-reading ability: Beliefs and performance. Journal of Research in Personality, 37(5), 420-445. https://doi.org/10.1016/S0092-6566(03)00021-7

Reddish, P., Tok, P., Kundt, R. (2016). Religious cognition and behaviour in autism: The role of mentalizing. The International Journal for the Psychology of Religion, 26(2), 95-112. https://doi.org/10.1080/10508619.2014.1003518

Richell, R. A., Mitchell, D. G. V., Newman, C., Leonard, A., Baron-Cohen, S., Blair, R. J. R. (2003). Theory of mind and psychopathy: Can psychopathic individuals read the 'language of the eyes'? Neuropsychologia, 41(5), 523-526. https://doi. org/10.1016/S0028-3932(02)00175-6

Salovey, P., Mayer, J. D. (1990). Emotional intelligence. Imagination, Cognition and Personality, 9, 185-211. https://doi.org/10.2190/DUGG-P24E-52WK-6CDG

Saroglou, V., Delpierre, V., Dernelle, R. (2004). Values and religiosity: A meta-analysis of studies using Schwartz's model. Personality and Individual Differences, 37(4), 721-734. https://doi.org/10.1016/j.paid.2003.10.005

Saroglou, V., Pichon, I., Trompette, L., Verschueren, M., Dernelle, R. (2005). Prosocial behavior and religion: New evidence based on projective measures and peer ratings. Journal for the Scientific Study of Religion, 44, 323-348. https://doi.org/10.1111/ j.1468-5906.2005.00289.x

Schjoedt, U., Stødkilde-Jørgensen, H., Geertz, A. W., Roepstorff, A. (2009). Highly religious participants recruit areas of social cognition in personal prayer. Social $\operatorname{Cog}$ nitive and Affective Neuroscience, 4(2), 199-207. https://doi.org/0.1093/scan/nsn050 
Sedikides, C., Gebauer, J. E. (2010). Religiosity as self-enhancement: A meta-analysis of the relation between socially desirable responding and religiosity. Personality and Social Psychology Review, 14, 17-36. https://doi.org/10.1177/1088868309351002

Shariff, A. F., Norenzayan, A. (2007). God is watching you: Priming God concepts increases prosocial behavior in an anonymous economic game. Psychological Science, 18(9), 803-809. https:/ / doi.org/10.1111/j.1467-9280.2007.01983.x

Shenhav, A., Rand, D. G., Greene, J. D. (2012). Divine intuition: Cognitive style influences belief in God. Journal of Experimental Psychology: General, 141(3), 423-428. https://doi.org/10.1037/a0025391

Sinclair, R. D. (1928). A comparative study of those who report the experience of the divine presence and those who do not. University of Iowa Studies in Character, 2, 1-62.

Singer, T., Lamm, C. (2009). The social neuroscience of empathy. Annals of the New York Academy of Sciences, 1156(1), 81-96. https://doi.org/10.1111/j.17496632.2009.04418.x

Small, D. A., Loewenstein, G., Slovic, P. (2007). Sympathy and callousness: The impact of deliberative thought on donations to identifiable and statistical victims. Organizational Behavior and Human Decision Processes, 102(2), 143-153. https://doi. org/10.1016/j.obhdp.2006.01.005

Stafford, R. Q., MacDonald, B. A., Jayawardena, C., Wegner, D. M., Broadbent, E. (2014). Does the robot have a mind? Mind perception and attitudes towards robots predict use of an eldercare robot. International Journal of Social Robotics, 6(1), 17-32. https://doi.org/10.1007/s12369-013-0186-y

Stellar, J. E., Cohen, A., Oveis, C., Keltner, D. (2015). Affective and physiological responses to the suffering of others: Compassion and vagal activity. Journal of Personality and Social Psychology, 108(4), 572-585. https://doi.org/10.1037/pspi0000010

Stellar, J. E., Gordon, A. M., Piff, P. K., Cordaro, D., Anderson, C. L., Bai, Y., ..., Keltner, D. (2017). Self-transcendent emotions and their social functions: Compassion, gratitude, and awe bind us to others through prosociality. Emotion Review, 9(3), 200-207. https://doi.org/10.1177/1754073916684557

Taves, A. (2013). Building blocks of sacralities: A new basis for comparison across cultures and religions. W: R. F. Paloutzian, C. L. Park (red.), Handbook of the psychology of religion and spirituality (s. 138-161). Nowy Jork: The Guilford Press.

Van Cappellen, P., Toth-Gauthier, M., Saroglou, V., Fredrickson, B. L. (2016). Religion and well-being: The mediating role of positive emotions. Journal of Happiness Studies, 17(2), 485-505. https://doi.org/10.1007/s10902-014-9605-5 
Vonk, J., Pitzen, J. (2017). Believing in other minds: Accurate mentalizing does not predict religiosity. Personality and Individual Differences, 115, 70-76. https://doi. org/10.1016/j.paid.2016.06.008

Watson, P. J., Hood, R. W., Morris, R. J., Hall, J. R. (1984). Empathy, religious orientation, and social desirability. The Journal of Psychology: Interdisciplinary and Applied, 117(2), 211-216. https://doi.org/10.1080/00223980.1984.9923679

Waytz, A., Gray, K., Epley, N., Wegner, D. M. (2010). Causes and consequences of mind perception. Trends in Cognitive Sciences, 14(8), 383-388. https://doi. org/10.1016/j.tics.2010.05.006

Webster, G. D., Duffy, R. D. (2016). Losing faith in the intelligence-religiosity link: New evidence for a decline effect, spatial dependence, and mediation by education and life quality. Intelligence, 55, 15-27. https://doi.org/10.1016/j.intell.2016.01.001

Wicherts, J. M., Dolan, C. V., van der Maas, H. L. J. (2010). The dangers of unsystematic selection methods and the representativeness of 46 samples of African test-takers. Intelligence, 38, 30-37. https://doi.org/10.1016/j.intell.2009.11.003

Willard, A. K., Norenzayan, A. (2013). Cognitive biases explain religious belief, paranormal belief, and belief in life's purpose. Cognition, 129(2), 379-391. https://doi. org/10.1016/j.cognition.2013.07.016

Wulff, D. M. (1999). Psychologia religii. Klasyczna i wspótczesna. Warszawa: Wydawnictwa Szkolne i Pedagogiczne Spółka Akcyjna.

Xygalatas, D., Mitkidis, P., Fischer, R., Reddish, P., Skewes, J., Geertz, A. W., .., Bulbulia, J. (2013). Extreme rituals promote prosociality. Psychological Science, 24(8), 1602-1605. https://doi.org/10.1177/0956797612472910

Zuckerman, M., Li, C., Lin, S., Hall, J. A. (2020). The negative intelligence-religiosity relation: New and confirming evidence. Personality and Social Psychology Bulletin, 46(6), 856-868. https://doi.org/10.1177/0146167219879122

Zuckerman, M., Silberman, J., Hall, J. A. (2013). The relation between intelligence and religiosity: A meta-analysis and some proposed explanations. Personality and Social Psychology Review, 17(4), 325-354. https://doi.org/10.1177/1088868313497266 


\section{8.}

\section{Inteligentne metapoznanie, czyli jak wiedza o własnym umyśle może być przydatna w codziennym życiu²}

Maria Ledzińska (iD https://orcid.org/0000-0003-1961-550X

Uniwersytet Warszawski, Wydział Psychologii

marial@psych.uw.edu.pl

2 Przygotowano w ramach programu badań wspartego dotacją Wydziału Psychologii UW w 2019 roku.

SPOSÓB CYTOWANIA: Ledzińska, M. (2021). Inteligentne metapoznanie, czyli jak wiedza o własnym umyśle może być przydatna w codziennym życiu. W: M. Zajenkowski (red.), Inteligencja w codziennym życiu (s. 207-232). Warszawa: 
$99 \begin{aligned} & \text { iem, że nic nie wiem”, „mam zawodna pamięć”, , „nauka przy- } \\ & \text { chodzi mi najłatwiej, kiedy rozłożę sobie materiał na mniejsze } \\ & \text { części”, „to zadanie jest dla mnie za trudne” to stwierdzenia, }\end{aligned}$ które często słyszymy i wykorzystujemy w codziennym życiu, a które stanowią dobry przykład przejawu zjawiska zwanego metapoznaniem. Metapoznanie to poznanie poznania (Flavell, 1979), czyli wiedza o tym, jak działa nasz własny umysł, jakie ma ograniczenia, w jakich warunkach najsprawniej funkcjonuje. W niniejszym rozdziale przedstawiono wybrane wyniki badań nad tym specyficznym przejawem poznania. Pytania o to, jak umiejętnie wybierać informacje, jak porządkować własną wiedzę, wydają się być ważne zwłaszcza współcześnie, w obliczu rozwoju technologicznego. Jednym z jego licznych następstw jest stały przyrost informacji oraz wiedzy. Znajomość własnego umysłu i krytycyzm wobec dostępnych treści mogą stanowić przydatne narzędzia selekcji informacji oraz tworzenia w oparciu o nie wiedzy osobistej.

\section{ISTOTA I STRUKTURA METAPOZNANIA}

Najogólniej rzecz ujmujacc, terminem „metapoznanie” opatrzono procesy poznawcze skierowane na samych siebie - metapoznanie to zdolność umysłu do poznania siebie samego poprzez udział świadomości, monitorowanie i kontrolowanie działań poznawczych (Dunlosky, Metcalfe, 2009; Martinez, 2006). Z tego powodu nazwano je procesami wyższego rzędu. Zaangażowanie świadomości pozostaje dziś jednym z kontrowersyjnych zagadnień (Nelson, 1996). Niektórzy twierdza, że metapoznanie ma charakter świadomy, inni - że mamy niewielki dostęp do wyższych procesów poznawczych i świadomi jesteśmy zasadniczo jedynie ich rezultatów (np. skutków podjętej decyzji; Koriat, 2007). Zwolennicy pośrednich ujęć piszą o dwóch rodzajach metapoznania: jawnym (explicite), tj. powolnym, wymagającym wysiłku, i niejawnym (implicite), czyli automatycznym.

Studia metakognitywne oparto na założeniu, że umysł człowieka funkcjonuje na dwóch powiązanych ze sobą poziomach (Nelson, Narens, 1994). Pierwszy nazwano przedmiotowym (primary cognition), drugi - metapoznaw- 
czym (secondary cognition). Dychotomia Ja przedmiotowego i podmiotowego stanowi jeden z najstarszych i najlepiej znanych podziałów (James, 1890). W niniejszym tekście skupiono się na Ja przedmiotowym, czyli zdolności do traktowania siebie jako obiektu własnej uwagi i intencjonalnego myślenia o sobie. Możemy myśleć i reflektować na temat tego, jak myślimy. Możemy wyobrażać sobie jakieś zjawisko oraz odnosić się aktywnie do tych wyobrażeń. Możemy podejmować zamiar zapamiętania określonych treści, a planując swój udział w tym procesie, dobierać strategie i śledzić postęp w uczeniu się, dokonując (lub nie) zmian we własnej aktywności.

Istnieje podwójna relacja między wyróżnionymi poziomami pracy umysłu (Nelson, 1996). Pierwsza to sprawowanie kontroli - poziom przedmiotowy podlega regulacji przez poziom meta. Druga wiążę się z nadzorem (monitorowaniem) - z poziomu meta stwierdza się zmiany w poziomie przedmiotowym. Wyróżnia się zatem dwa rodzaje przetwarzania informacji. Na poziomie przedmiotowym jednostka koncentruje uwagę na wykonywanej czynności (ego doświadczające), podczas gdy na metapoziomie - skupia się na procesach poznawczych zaangażowanych w wykonywanie zadania (ego obserwujące). Funkcjonowanie na poziomie metapoznawczym wiąże się z rozróżnieniem myślenia od doświadczania siebie jako autora, obserwatora i korektora własnych myśli. Te ostatnie mogą dotyczyć siebie, innych oraz wzajemnych relacji.

Przywoływane poniżej ujęcia definicyjne ilustrują podobieństwo stanowisk badaczy uznawanych za ekspertów w charakteryzowanym obszarze studiów. Flavell (1979) - jeden z prekursorów opisywanej problematyki - pisał, że metapoznanie to poznanie na temat poznania. Koriat (2007) precyzował istote zjawiska, eksponując wiedzę o procesach poznawczych wraz ze sposobem jej wykorzystywania w kierowaniu przetwarzaniem i zachowaniem. Serra i Metcalfe (2009) opisują metapoznanie jako wiedzę o procesach poznawczych oraz ich monitorowanie i kontrolowanie. Nęcka, Orzechowski i Szymura (2013) twierdza, że metapoznanie to „zdolność umysłu ludzkiego do poznania samego siebie i zespół procesów poznawczych, zaangażowanych w poznanie innych procesów lub struktur poznawczych" (s. 639). Z kolei procesy metapoznawcze definiuja jako „operacje poznawcze odpowiedzialne za planowanie czynności, nadzór i kontrolę nad ich wykonaniem, a także analizę informacji zwrotnych i związane z tym procesy uczenia się" (Nęcka i in., 2013, s. 649).

Większość badaczy wymienia dwa ogniwa metapoznania: wiedzę i umiejętności (np. Flavell, 1979; Norman, Pfhul, Saele, 2019). Wiedza metapoznawcza jest szerszym terminem, jako że obejmuje przekonania (treści), jakie posiada jednostka o jej własnym poznaniu. To wiedza deklaratywna o nas jako isto- 
tach poznających, czyli o naszym umyśle oraz o czynnikach wpływających na przebieg i wynik procesów poznawczych. Może być ona zgodna z rzeczywistościa (przekonania funkcjonalne) lub z nią niezgodna (przekonania dysfunkcjonalne). Umiejętności zaś to różnorodne sprawności przynależne do wiedzy proceduralnej. Zalicza się do nich aktywność regulacyjną przyjmująca postać formułowania celów, monitorowania oraz kontroli, które umożliwiają samoregulację (Ledzińska, Zajenkowski, Stolarski, 2013). Istotą tej ostatniej pozostaje korygowanie myśli, emocji i zachowania pod kątem realizacji celu. Uznawana jest za najbardziej złożoną i przez to energochłonną umiejętność metapoznawczą. Efklides (2008) do wiedzy i umiejętności dołączyła dodatkowy element, tj. doświadczenia metakognitywne, umiejscawiając je między wiedzą a umiejętnościami. Traktowała je też jako ogniwo pośredniczące między człowiekiem a rozwiązywanym przezeń zadaniem oraz między monitorowaniem a kontrola.

\section{METAPOZNANIE A INTELIGENCJA}

Zrozumienie miejsca metapoznania w strukturze inteligencji może ułatwić przywołanie koncepcji Roberta Sternberga, jednego z najbardziej znanych badaczy metapoznania i inteligencji. Sternberg $(1985,2004)$ zaproponował triadową koncepcję inteligencji jako odpowiedź na trzy pytania. Po pierwsze: co się dzieje, gdy człowiek myśli inteligentnie? Jakie rodzaje, procesów umysłowych i strategii dają bardziej lub mniej inteligentne zachowanie? Odpowiedź brzmiała: inteligencja jest kombinacją procesów informacyjnych koniecznych do wykonywania różnych zadań. Badacz nazwał je komponentami, wyróżniając kolejno te odpowiedzialne za nabywanie wiedzy, za wykonanie, oraz tak zwane metakomponenty. Tym ostatnim nadał najwyższy status. Metakomponenty (metaskładniki) sa procesami przetwarzania wyższego rzędu. Zaliczył do nich planowanie, decydowanie, ocenianie i kontrolę. Nadzorują on przebieg procesów niższego rzędu, związanych z nabywaniem wiedzy oraz wykonywaniem czynności, czyli strategii poznawczych zaangażowanych w rozwiązywanie zadań. Metaskładniki odnosił ponadto do rozwiązywanego problemu, wyodrębniając np. jego dostrzeżenie, zdefiniowanie istoty, wybór składników niższego rzędu (sposób organizacji informacji, decyzje o zaangażowaniu uwagi, wrażliwość na informacje zwrotne).

Drugie z tzw. wielkich pytań sformułowanych przez Sternberga brzmiało: co stanowi o istocie relacji do świata zewnętrznego? W tym obszarze wyodrębnił umiejętność radzenia sobie z nowymi zadaniami oraz zdolność do automatyzacji przetwarzania, współdecydującą o ekonomiczności działań. 
Trzecie zapytanie dotyczyło natury związku między jednostką a jej indywidualnym doświadczeniem. Pozostaje nim adaptacja do środowiska oraz aktywne kształtowanie go poprzez wybór otoczenia, w którym możliwe jest efektywne funkcjonowanie. Inteligencja wyznaczana jest ponadto przez środowisko społeczno-kulturowe; nie istnieje poza tym kontekstem. Myśl, że nie tyle ważny jest jej poziom, ile ukierunkowanie i wykorzystanie - znalazła wyraz w dwóch późniejszych koncepcjach badacza.

Istotnym problemem pozostają związki między inteligencją, metapoznaniem i osiagnięciami w różnych sferach aktywności, m.in. w nauce szkolnej. Stanowisko Sternberga (2004) jest w tej kwestii jasne - metapoznanie wchodzi w skład inteligencji jako jedno z jej podstawowych ogniw. Z kolei o efektywności inteligencji decydują relacje z pozostałymi składnikami, wymienione wcześniej związki z doświadczeniem i kontekstem. Nie sposób wyobrazić sobie osoby inteligentnej bez rozległej wiedzy i ukształtowanych umiejętności metapoznawczych.

Sternberg kontynuowal prace nad autorskim modelem inteligencji eksponującym znaczenie metapoznania. Pierwszym z nich pozostaje propozycja inteligencji sprzyjającej powodzeniu życiowemu (Sternberg, 2005a) rozumianemu jako realizowanie celów w środowisku życia przez wykorzystanie zdolności i cech osobowości. Myśl, że inteligencja przejawia się w realizacji potencjału, której wskaźnikiem pozostaje sukces życiowy - pozostała. Ale osiaganie celów związał autor jeszcze silniej z adaptacją do środowiska, akcentując także znaczenie jego modyfikacji w kierunku sprzyjającym rozwojowi. Jest to możliwe przez zaangażowanie trzech rodzajów zdolności: analitycznych praktycznych i twórczych (Strernberg, 2001, 2002, 2005a). Najnowszy z zaproponowanych modeli teoretycznych - znany jako WICS - uwzględnia aż cztery wyznaczniki życiowego powodzenia: mądrość, inteligencję, twórczość i syntezę - skrót od angielskich słów daje akronim WICS (Sternberg, 2005b). Stanowiska badacza ewoluowały zatem w kierunku ujęć całościowych, a ostatnia propozycja teoretyczna ilustruje wielką złożoność uwarunkowań powodzenia życiowego.

Wyniki dotychczasowych badań na związkiem między inteligencją, umiejętnościami metakognitywnymi i efektywnością działania nie sa jednoznaczne. W odniesieniu do rezultatów w nauce szkolnej przedstawiają się na dzień dzisiejszy następująco: zdolności intelektualne i metapoznawcze współwystępują oraz moga łącznie przyczyniać się do uzyskiwania wysokich wyników (Cornoldi, 2010; Limont, 2010; Sękowski, 2000). Predykcje oparte na testach zdolności intelektualnych i umiejętności metapoznawczych czasami się pokrywają. Jest to interpretowane jako dowód na tożsamość inteligencji i metapoznania. Wspiera- 
ją to stanowisko niektóre analizy osiagnięć uczniów i studentów o zróżnicowanym poziomie inteligencji (Ledzińska, 1996; Świerżewska-Chadaj, Ledzińska, 2017). Stwierdzono także efekt samodzielnego oddziaływania metapoznania, które może stanowić wartość dodana do inteligencji. Po zestawieniu danych dotyczących osiaggnięć niższych niż przeciętne u osób zdolnych lub w normie intelektualnej stwierdzono, co następuje (Czerniawska, 2006). Słabo wyksztalcone umiejętności metapoznawcze mogą się przyczyniać do obniżenia dostępnego poziomu osiagnięć, wynikającego z posiadanego ilorazu inteligencji. Natomiast w przypadku osób o wysokim poziomie zdolności umiejętności metapoznawcze słabiej wpływają na osiagane efekty. Przypuszcza się, że dla zaktywizowania umiejętności metapoznawczych potrzebny jest określony poziom rozwoju intelektualnego. Z kolei ponadprzeciętne zdolności są wystarczająca podstawą sprawnego funkcjonowania, stąd u takich osób wiedza i umiejętności metapoznawcze nie muszą osiagać wysokiego pułapu.

Złożoność diagnozy metapoznania według ujęcia Sternberga oraz metodologiczna orientacja badacza (zwolennik prac eksperymentalnych) stanowiły pewną przeszkodę w aplikacji jego idei. Łatwiej mierzyć i badać inteligencje traktowaną jako cecha lub zespół cech niż zdolności w ujęciu procesualnym. Niemniej jednak, badania wskazują na doniosłą rolę procesów metapoznawczych w naszym życiu. Poniżej wskazano na znaczenie metapoznania w zakresie: (1) wiedzy o sobie, (2) regulacji (monitorowania oraz kontroli) i (3) doświadczeń metakognitywnych.

\section{Z BADAŃ NAD WIEDZĄ METAPOZNAWCZĄ}

Metawiedza jest jednym z ogniw samowiedzy i studia nad nią trudno przecenić. Samowiedza obejmuje wszystko, co wiemy na swój temat i zbudowana jest - analogicznie do wiedzy o świecie - z reprezentacji i schematów poznawczych (Bąk, 2017; Dymkowski, 1993; Kozielecki, 1986). Wypowiedzi typu „wiem, że wiem” albo „wiem, że nic nie wiem”, albo „wiem niewiele” są reprezentatywne dla funkcjonowania na poziomie metapoznawczym. Jednym z jego przejawów pozostaje także wykraczanie poza posiadaną wiedzę zapisaną np. w postaci osobistych doświadczeń. Intelektualne i emocjonalne przepracowywanie minionych zdarzeń z udziałem umysłu i woli stanowi jedno $z$ ważnych zadań rozwojowych. W psychologii i pedagogice bywa ono określane mianem samowychowania.

Ten element samowiedzy, jaki stanowia - podlegające modyfikacji - przekonania na swój temat, ma złożone uwarunkowana społeczne i cechuja go 
ważne właściwości funkcjonalne. Wczesne doświadczenia wpływają bowiem na to, jak postrzegamy siebie i otoczenie. Stosunek do siebie jest funkcją oceny własnych postępów oraz sukcesów w obszarach postrzeganych subiektywnie jako ważne. Ocena ta generalizowana jest następnie na ogólny sąd na temat siebie i własnej wartości. Pozytywny stosunek do siebie i innych pełni ważną rolę regulacyjną: kształtuje dobrostan jednostki oraz rodzi zaufanie do innych, sprzyja też poszukiwaniu optymalnych rozwiązań codziennych trudności, co pozwala na zdobycie nowych kompetencji i podtrzymanie wiary we własna skuteczność (m.in. Greenberg, Arndt, 2011). Studia nad przekonaniami o sobie i innych, ich regulacyjnej funkcji oraz możliwości modyfikacji rozwijane są w ramach różnych podejść teoretycznych. Popularne nurty znane są pod nazwą metapoznania społecznego, teorii umysłu, mentalizowania.

\section{Z BADAŃ NAD KONTROLĄ I REGULACJĄ}

Dla terminu „samokontrola” znajduje się w literaturze równoważne określenia jak „podmiotowość”, „swoboda wyboru”, „poczucie sprawstwa”, ,autonomia decyzji”, „przyjmowanie osobistej odpowiedzialności” (Krzyżewski, 2008). Psychologiczne ujęcie jej istoty nawiązuje wprost do propozycji sformułowanej na gruncie teorii systemów i nazwanej sterowaniem, tj. celowym dokonywaniem zmian w układzie (Kempisty, 1973). Psychologowie o orientacji poznawczej rozumieją kontrolę na dwa sposoby - albo nieco węziej, jako obecność procesów organizujących inne czynności umysłowe, albo trochę szerzej, tzn. jako sposób zachowania umożliwiający wywieranie rzeczywistego wpływu na bieg zdarzeń. W pracach empirycznych dominuje tzw. podejście analityczne, ukierunkowane na poznawanie indywidualnych różnic w zakresie efektywności kontroli (Chuderski, 2010).

W literaturze spotkać można różne klasyfikacje kontroli (Rachlin, 2000). Podział na poznawczą i behawioralną należy do najbardziej znanych (Kofta, 2001). Funkcja kontroli behawioralnej zwanej też sprawczą polega na kierowaniu wydarzeniami przy pomocy intencjonalnych działań, poprzedzanych sformułowaniem celu. Jej przeciwieństwem jest bierność, podporządkowanie, zależność od otoczenia. Z kolei na kontrolę poznawczą składa się rozumienie zjawisk i związane z nim przewidywanie możliwych następstw. Sedno ich zależności polega na tym, że kontrola poznawcza stanowi istotny, ale niewystarczający warunek skutecznej kontroli behawioralnej, zaś sprawowanie kontroli behawioralnej może zwiększać poziom kontroli poznawczej. 
Jeśli wywieranie wpływu na otoczenie polega na wprowadzaniu zmian odpowiadających naszym potrzebom, to mamy do czynienia z kontrolą pierwotną. Natomiast przystosowywanie się do wymagań sytuacji jest przejawem kontroli wtórnej. Opiera się ona na dwóch podstawowych odmianach kontroli poznawczej, tj. interpretacyjnej i predykcyjnej. Interpretacyjna polega na aktywnym poszukiwaniu sensu zdarzeń tak, aby stały się możliwe do zaakceptowania. Natomiast w centrum kontroli predykcyjnej leży sterowanie oczekiwaniami: jeśli nie sposób osiagnąć celu, to można przeformułować nastawienie, chroniąc się przed doświadczeniem porażki (Maciuszek, 2007). W literaturze spotyka się ponadto kategorię poczucia kontroli, pojmowana jako przekonania na temat możliwości jej sprawowania (Bandura, 1997).

W studiach metapoznawczych uwypukla się funkcjonalne znaczenie samokontroli. Analogicznie do kontroli sprawowanej nad otoczeniem, przyjmuje ona postać zarówno kontroli poznawczej, gdy rozumiemy nasze myśli i uczucia (znamy też ich źródła), jak i kontroli behawioralnej, wyrażającej się wywieraniem wpływu na własne myśli (kontrola mentalna) i emocje (kontrola afektywna). Sednem kontroli umysłowej (mentalnej) jest troska o zgodność naszych intencji z tym, co dzieje się w zakresie myśli, przeżyć i działań. Obszar przejawiania się tej kontroli jest bardzo szeroki i obejmuje dążenie do uzyskania określonych stanów umysłu oraz unikania innych. Zatem kontrola myśli polega na kierowaniu uwagi na pewne treści i na oddalaniu niektórych wątków myślenia, tj. ich tłumieniu i/lub eliminowaniu. Z kolei przykładem kontroli uczuć są próby uzyskania określonych stanów emocjonalnych lub wyjścia ze stanów niepożądanych. Kontrola działań polega na monitorowaniu ich przebiegu, utrzymywaniu kierunku czynności i wpływaniu na poziom wykonania. Jej urzeczywistnianie wymaga monitorowania myśli, uczuć i zachowania oraz wpływania na nie wówczas, gdy wykryje się stan niezgodny z zamierzonym (Wegner, Wenzlaff, 1996). Wielokierunkowość badań nad samokontrolą ilustruja poniższe przykłady.

KONTROLA MYŚLI NA PRZYKŁADZIE STUDIÓW NAD INTRUZJAMI. Za myśl intruzyjną uważa się „każde wyraźne, możliwe do identyfikacji zdarzenie poznawcze, które jest niechciane, niezamierzone i powtarzające się. Przerywa strumień myśli, przeszkadza w wykonywaniu zadań, jest powiązane z negatywnym afektem i jest trudne do kontroli” (Clark, Rhyno, 2005, s. 4). Stosunkowo niedawno zwrócono uwagę na pojawianie się myśli intruzyjnych w populacji zdrowych. Wcześniejsze badania skoncentrowane były na osobach z wyraźnie zdiagnozowanymi zaburzeniami, gdzie intruzje bywaja jednym z głównych ele- 
mentów definicyjnych (por. zaburzenia obsesyjno-kompulsywne, depresja czy zespół stresu pourazowego). Rachman i de Silva (1978) jako pierwsi stwierdzili pojawianie się intruzji wśród typowej populacji. Wyniki ich badań pokazały, że aż 84\% osób doświadcza nieprzyjemnych, często bardzo przykrych myśli intruzyjnych. Są one w populacji zjawiskiem powszechnym, zaś grupy kliniczne i kontrolne różnicuje intensywność intruzji, a nie ich treść.

Istotną komponentą intruzji są negatywne emocje (np. uczucie smutku, martwienie się) oraz trudność w pozbyciu się ich. Obydwa czynniki są ze sobą skorelowane (Clark, de Silva, 1985). Warto także dodać, że im myśl oceniana jest jako bardziej męcząca, nieprzyjemna czy wzbudzająca lęk, tym staje się trudniejsza do kontrolowania i usunięcia. Z kolei poczucie odpowiedzialności za myśli oraz obawa przełożenia ich na realne konsekwencje czyni intruzje bardziej natrętnymi i uporczywymi. Stwierdzenia te zachęciły badaczy do poszukiwania przyczyn intruzywności w specyfice przekonań i sposobie funkcjonowania uwagi. Piszę o tym nieco później, omawiając mechanizmy dysfunkcji kontroli. Istota i powszechność intruzji myślowych zachęciły też do poszukiwania jej temperamentalnych wyznaczników. Wyniki badań (m.in. Ledzińska, Zajenkowski, Stolarski, 2013) potwierdziły m.in. związek cech temperamentu z tendencją do występowania myśli intruzyjnych. Wykazano znaczenie perseweratywności i reaktywności emocjonalnej jako korelatów intruzji.

KONTROLA I REGULACJA EMOCJI. Badania nad kontrolą emocji prowadzono w ramach różnych podejść. Przytaczam dwa z nich. Pierwsze, szersze, wiąże się z wprowadzeniem do analiz kategorii ,inteligencja emocjonalna”. Drugie, węższe, sprowadza się do poznawania zjawiska zarządzania emocjami, czyli poznawania typów kontroli emocji i identyfikowaniu przyczyn trudności w jej urzeczywistnianiu.

Pojęcie inteligencji emocjonalnej, zaproponowane przez Petera Saloveya i Johna Mayera (1990), stało się szybko jednym z najważniejszych terminów psychologii różnic indywidualnych. Ten rodzaj inteligencji definiuje się jako „zdolność do śledzenia cudzych oraz własnych uczuć i emocji, rozróżniania ich i wykorzystywania tego rodzaju informacji w kierowaniu własnym myśleniem i działaniem" (Mayer, Salovey, 1999, s. 34). Autorzy modelu wyróżnili cztery grupy zdolności: percepcję, rozważanie i wyrażanie emocji, emocjonalne wspomaganie myślenia, rozumienie i analizę emocji oraz wykorzystywanie wiedzy emocjonalnej, świadomą regulację emocji w celu wspierania rozwoju emocjonalnego i intelektualnego. Pomysł ten nie wyczerpuje puli istniejących koncepcji. Tworzą one dwie grupy. Pierwsza składa się z modeli traktujących 
inteligencję jako zdolność lub grupę zdolności (Salovey, Detweiler-Bedell, Detweiler-Bedell, Mayer, 2008). Autorzy należący do drugiej grupy ujmuja znacznie szerzej inteligencję emocjonalną, włączając weń - obok zdolności - szeroko rozumiane kompetencje społeczne, a nawet zmienne osobowościowe. Istotą odmienności wymienionych podejść do inteligencji jest to, że pierwsza warunkuje zachowania maksymalne, zaś druga - typowe (Matczak, 2006). W pogłębionych opisach pojawiają się - w związku z różnica podejść - różne nazwy, tj. inteligencja emocjonalna poznawcza, działaniowa, związana z doświadczeniem, strategiczna. Podsumowanie wyników prac nad IE znaleźć można w tekstach przeglądowych (Matczak, Knopp, 2013; Śmieja, 2018; Śmieja, Orzechowski, 2008).

W nurcie prac poświęconych zarządzaniu emocjami eksponowane miejsce stanowią te poświęcone strategiom regulacji emocji (Salovey i in., 2008). Nie sposób pominąć ujęcia Grossa (1998), uznającego regulację emocji za jeden z głównych procesów szerszego zjawiska, jakim jest regulacja afektywna. To procesy, dzięki którym człowiek wpływa na to, jakie emocje się u niego pojawiają oraz w jaki sposób je doświadcza i wyraża (Gross, 1998).

Generowanie emocji ma swoją dynamikę w czasie, stąd regulacja emocji może nastąpić w różnych momentach, zmieniając przebieg tego procesu. Strategie występujące przed reakcja, gdy emocja jeszcze nie przybrała ostatecznego kształtu, nazywane są regulacją poprzedzająca. Przejawiają się wycofaniem się z sytuacji, przekierowaniem uwagi lub zmianą sposobu myślenia o sytuacji. Gdy reakcja emocjonalna w pełni się rozwinie, aktywowana może zostać regulacja korygująca. To właśnie na styku zmiany poznawczej i modulacji reakcji pojawiają się dwie znaczące strategie regulacyjne, czyli przeformułowanie i tłumienie. Przeformułowanie poznawcze zakłada zmianę sposobu myślenia o sytuacji tak, aby wpłynął na odczuwane emocje. Z kolei tłumienie to powstrzymywanie myśli i zachowań związanych z niechcianymi emocjami.

Kluczowym zagadnieniem pozostaje umiejętność dostosowania strategii do sytuacji, a także wczesne rozpoznawanie okoliczności, która może wywołać niepożądane emocje. Regulacja na wcześniejszym etapie jest skuteczniejsza i wiążą się z nią niższe koszty emocjonalne, poznawcze i społeczne. Regulacja wyprzedzająca ma miejsce na wczesnym etapie wzbudzania emocji. Regulacja korygująca stanowi natomiast odpowiedź na wzbudzoną już reakcję emocjonalna, którą można modyfikować (Gross, 1998, 1999).

Adaptacyjna regulacja emocji ma swój przeciwny biegun - dysregulację, czyli trudności w regulacji emocji. W oparciu o dane z literatury Gratz i Roemer (2004) wyróżniły czynniki, które sprzyjają regulacji: (1) świadomość emo- 
cji i ich rozumienie, (2) akceptacja tych nakierowanych na realizację celów (także podczas doświadczania negatywnych emocji) oraz (3) umiejętność trafnego wyboru strategii regulowania emocji, która implikuje odpowiedź emocjonalną zależnie od sytuacji. Deficyty w wymienionych obszarach zaburzaja zdolność do regulacji emocji, prowadząc do dysregulacji. Jest ona przyczyną wielu zburzeń. Dragan (2016) opisuje na przykład problemy z regulacją emocji, $z$ radzeniem sobie $z$ negatywnym afektem i stosowaniem skutecznych strategii u kobiet z problemowym piciem alkoholu.

KONTROLA I REGULACJA UCZENIA SIĘ. Badania nad przebiegiem i efektami uczenia się stanowią dobry przykład identyfikacji procesów kontrolnych w codziennym życiu (Azevedo, Aleven, 2013; Schwarz, Tsang, Blair, 2016). Psychologowie poznawczy przez uczenie się rozumieją rozłożony w czasie proces budowania w umyśle systemów wiedzy oraz skutecznych sposobów dostępu do nich, umożliwiających efektywne wykorzystanie w różnych sytuacjach (Ledzińska, Czerniawska, 2011). Nauczanie uczenia się - jedno z zadań współczesnej szkoły - dokonuje się stopniowo, a istotnym jego elementem pozostaje zrozumienie przez ucznia roli własnego zaangażowania poznawczego. Może ono przyjmować postać intencjonalnej aktywności ukierunkowanej na zapamiętanie lub zaktualizowanie potrzebnych informacji. Podejmowane przez uczącego się różnorodne działania określane są w literaturze mianem strategii uczenia się. Studia nad ich rozwojem, uwarunkowaniami oraz związkiem z wynikami uczenia się stanowią od lat nurt intensywnych badań (Ledzińska, Czerniawska, 2011).

Ważną ich część stanowią studia nad strategiami prowadzone m.in. pod kątem użyteczności stosowanych strategii. Ich wartość wiązana jest zazwyczaj z umiejętnością dopasowania działań do właściwości jednostki oraz celu uczenia się i określa się ją mianem giętkości strategicznej. Wyróżnia się kilka jej rodzajów, w tym przede wszystkim intrazadaniowa, polegająca na zmianach w stosowanych strategiach zachodzących w trakcie uczenia się epizodycznego, oraz interzadaniowa, polegającą na różnicowaniu zachowań w zależności od specyfiki zadania (Czerniawska, 1999). Robert Cantwell (1997) sformułował w tym obszarze studiów oryginalną koncepcję, w ramach której wyodrębnił trzy obszary metapoznania. Stanowia je: (1) wiedza o sposobach i strategiach uczenia się, (2) przekonania na temat własnej umysłowości oraz (3) samoregulacja uczenia się (obserwowanie postępów, wpływanie na osiagane efekty). To zaledwie jedno z wielu ujęć teoretycznych z omawianego obszaru studiów. Koncepcji tzw. uczenia samoregulowanego jest wiele, a ich szczegółowe omó- 
wienie znaleźć można w dostępnych podręcznikach (Hacker, Dunlosky, Graesser, 2009; Ledzińska, Czerniawska, 2011; Littleton, Wood, Kleine Staarman, 2010).

Sednem propozycji pozostaje teza, że różnice indywidualne w rodzaju (i jakości) sprawowanej kontroli można opisywać w kategoriach adaptacyjności lub jej braku, czyli nieadaptacyjności (Cantwell, Moore, 1996). Szczegółowo rzecz ujmując, procesy kontrolne uruchamiane przez uczącego się mogą prowadzić do podejmowania aktywnej, skutecznej samoregulacji, której istotą pozostaje strategiczna giętkość. Jest to elastyczność w obszarze stosowanych strategii poznawczych, czyli adekwatność, umiejętność dopasowania do specyfiki sytuacji. Z kolei kontrola nieadaptacyjna jest niedostosowana do zadań i przyjmuje postać aktywności sztywnej bądź chwiejnej (niezdecydowanej). Rodzaj inicjowanej samoregulacji zależy - zdaniem badacza - przede wszystkim od przekonań osób uczących się na temat znaczenia procesów kontrolnych w uczeniu się. O specyfice referowanego podejścia decyduje zatem stwierdzenie, że wspomniane różnice przekonań mają charakter jakościowy, a nie ilościowy. Osoby uczące się w sposób efektywny są przekonane, iż skuteczne uczenie się wymaga planowania działań oraz ich nadzorowania, czyli aktywnej adaptacji do wymagań stawianych przez szkołę. Samoregulacja osób osiagających wysokie wyniki w uczeniu się jest zatem interpretowana jako wynik plastyczności w planowaniu działań, ich uruchamianiu oraz monitorowaniu. Z kolei sztywność lub chwiejność w realizowaniu kontroli cechuje osoby osiagające niskie wyniki w uczeniu się.

MECHANIZMY KONTROLI. Kontrola umysłu bywa zawodna, a o jej skuteczności decyduje dostępność zasobów poznawczych. Z osłabieniem lub utratą kontroli mamy do czynienia przede wszystkim w sytuacji ograniczenia zasobów. Zubożenie to ma miejsce najczęściej w sytuacji obciążenia poznawczego, emocjonalnego lub działania pod presją czasu. Przeciążenie pamięci operacyjnej skutkuje osłabieniem procesów wykonawczych. Upośledza się selekcja informacji, a proces monitorujący wprowadza do świadomości treści niezgodne z realizowanym celem. Doświadczamy - sygnalizowanej wcześniej - intruzji myśli; w polu świadomości pojawiają się wątki pozostające bez związku z rozwiązywanym problemem. Tracimy zdolność sprawowania kontroli z powodu osłabienia hamowania poznawczego (Engle, Conway, Tuholski, Shisler, 1995).

$\mathrm{Na}$ gruncie psychologii poznawczej mechanizmy inhibicyjne traktowane sa jako jedne $z$ ważniejszych w procesie przetwarzania informacji (Dagenbach, Carr, 1994). Wyróżnia się dwa ich rodzaje: wzmacniające oczekiwana, potrzeb- 
ną informację oraz osłabiające przetwarzanie danych niezwiązanych z wykonywanym zadaniem. Lepiej poznano te ostatnie, chroniące pamięć operacyjną przed wtargnięciem weń treści będących bez związku z realizowaną aktywnością i usuwające zeń elementy niepotrzebne do jego realizacji. Hamowanie poznawcze polega przede wszystkim na tłumieniu tego, co nie jest ważne w danej chwili, na aktywnym blokowaniu wzbudzonej aktywności umysłowej, oddalaniu treści niewiążących się z zadaniem. Wydolny, efektywny mechanizm inhibicyjny kształtuje „centrum umysłu”, pozostawiając w polu analiz treści związane bezpośrednio z realizowaną aktywnością. Warto wskazać także na zjawisko hamowania behawioralnego, obejmującego powstrzymywanie się od dominującej, narzucającej się lub stereotypowej reakcji. Deficyt inhibicyjny zmniejsza z kolei efektywność spostrzegania, pamięci, myślenia, decydowania, działania. Skutki obserwujemy w codziennym życiu, a do najczęstszych zalicza się uzależnienie myśli, uczuć, zachowań od czynników sytuacyjnych, trudność utrzymania obranego kierunku działania, przedwczesne porzucanie celu, ale także sztywność zachowania, niezdolność oparcia się impulsom itp.

Oryginalne wyjaśnienie dysfunkcji kontroli w powstawaniu i utrzymywaniu się zaburzeń przedłożyli przed laty Wells i Matthews (1994). Badacze ci stworzyli model tzw. samoregulującej funkcji wykonawczej (S-REF). Nazwa ta obejmuje umiejętności umożliwiające wymianę informacji pomiędzy różnymi poziomami przetwarzania. Uruchamiana jest w sytuacji stwierdzania trudności w realizacji celów w postaci adaptacyjnych lub nieadaptacyjnych sposobów myślenia, przeżywania i zachowania. Nieadaptacyjne badacze nazwali syndromem poznawczo-uwagowym, wymieniając wśród nich zamartwianie się, koncentrowanie uwagi na zagrożeniach czy trwanie przy pewnych przekonaniach na swój temat. Syndrom ten sprawia, że absorbowane są zasoby uwagi i uszczuplane bieżące przetwarzanie. Propozycja Wellsa i Matthewsa jest użytecznym poznawczo i praktycznie modelem samoregulacji (Vohs, Baumeister, 2017).

\section{Z BADAŃ NAD DOŚWIADCZENIAMI METAPOZNAWCZYMI}

Doświadczenie metapoznawcze stanowi odmianę doświadczenia indywidualnego. Jak zauważa Allport, „osoba jest żyjącą całością, indywidualna, jedyną, dążącą do celów, zwartą w sobie, a jednocześnie otwartą na doświadczenie" (Allport, 1960, s. 38). Stanowiąc jedność w różnorodności, osoba kształtuje się w procesie interakcji z otoczeniem. Koncentrując się głównie na zagadnieniu rozwoju osobowości jako procesu stawania się indywidualnością poprzez aktualizację tego, co najbardziej osobiste, Allport rozwinął tezę o osobowej 
zdolności do posiadania doświadczeń (1988). Spośród ośmiu funkcji proprium, ostatnia - bycie podmiotem poznania - uznał za podstawową funkcję ludzkiej osobowości. Autor tak pisał o podmiotowej, poznawczej funkcji proprium: ,poznajemy nie tylko rzeczy, ale i empiryczne cechy naszego własnego proprium. To ja mam wrażenia cielesne, ja odczuwam z dnia na dzień własną tożsamość, ja zdaję sobie sprawę z mej woli mocy, z poszerzania własnego ja, z moich własnych racjonalizacji, interesów i dążeń. Gdy więc myślę o funkcjach swego proprium, łatwo dostrzegam, że występują one łącznie, i czuję, że są blisko związane z samą funkcją poznawczą" (Allport, 1988, s. 47).

Koncepcję doświadczenia osobowego rozwija dziś wielu badaczy. Podkreślają oni, i jest to wyróżnik współczesnych podejść, że:

- potrafimy doświadczyć siebie jako podmiotu oraz przedmiotu tego, co się zdarza,

- istniejemy w świecie poprzez różne sposoby doznawania i działania,

- doświadczamy zdarzeń mających konkretne zakotwiczenie w czasie i przestrzeni,

- możliwa jest zmiana odniesień do tego, co nas spotkało (Heidegger, 2000).

DOŚWIADCZENIA METAPOZNAWCZE W RELACJACH MIĘDZYLUDZKICH. Jednym z najlepiej znanych ujęć istoty i genezy relacji międzyludzkich pozostaje teoria przywiązania Bowlby'ego (2007). Autor twierdzi, iż pragnienie psychicznej oraz fizycznej bliskości jest pierwotną, biologicznie zdeterminowana potrzebą każdego człowieka. Wrażliwość i adekwatna reakcja opiekuna na potrzeby dziecka buduja poczucie bezpieczeństwa oraz kształtują stosunek do siebie i innych. Pierwotne więzi z opiekunami stanowią zatem wzorzec, prototyp relacji interpersonalnych w dorosłym życiu. W oparciu o założenia tejże teorii Ainsworth (1978, za: Bowlby, 2007) opisała trzy typy stylów przywiązania, definiowane poprzez poziom wrażliwości oraz dostępności matki w relacji z dzieckiem. Znamy je jako styl bezpieczny, lękowo-ambiwalentny i unikający. Zdaniem Main (np. Main, Solomon, 1986; Main i in., 1985) jakość więzi z podstawowym opiekunem ma związek z reprezentacjami umysłowymi, które nazwane zostały Wewnętrznymi Modelami Roboczymi. Zawierają one reprezentację siebie, opiekuna oraz ich wzajemnej relacji. Novum ujęcia badaczki pozostaje stwierdzenie o regulacyjnej sile WMR - zarządzają one procesami poznawczymi związanymi z przywiązaniem (Main i in., 1985), emocjami oraz zachowaniem jednostki. Model bezpiecznej więzi jest jednorodny i spójny, 
a modele więzi pozabezpiecznych pozostaja niejednorodne oraz pozbawione spójności. Ważnym etapem rozwoju koncepcji było rozróżnienie reprezentacji psychicznej (,Jestem impulsywna”) od metareprezentacji (,Jestem osoba, która często postrzega siebie jako impulsywna"). Autorka uwypukliła różnicę między subiektywnym doświadczeniem zapisanym w ludzkiej pamięci a przekraczaniem go. Jak pisał Bruner (1978), możemy wykraczać poza dostarczone informacje. Obdarzeni zdolnością do refleksji jesteśmy w stanie zdobywać dystans do tego, co nas spotkało i co przechowujemy w pamięci autobiograficznej. Zdolność do wychodzenia poza własne doświadczenia i przeformułowania ich psychologicznego sensu stanowi istotę omawianego konstruktu.

W studiach metapoznawczych Main, Hesse i Goldwyn (2008) uwypuklaja znaczenie sposobu relacjonowania doświadczenia. Wywiad Przywiązania Dorosłych (Adult Attachment Interview) stanowi dogodną technikę jego diagnozy. Uzyskane dane analizowane są pod kątem treściowym i formalnym; ocenia się m.in. sposób funkcjonowania uwagi. Uważa się, że tak jak niemowlę ufnie przywiązane do podstawowego opiekuna potrafi elastycznie przełączać uwagę pomiędzy poszukiwaniem bliskości a eksplorowaniem środowiska, tak osoba dorosła o bezpiecznym wzorcu więzi potrafi przestawiać się pomiędzy referowaniem doświadczenia więzi a oceną jego znaczenia dla kształtu jej życia. Naprzemienne przywoływanie własnego doświadczenia oraz wykraczanie poza nie stanowi przejaw rekonstruowania doświadczenia.

Owa rekonstrukcja pozostaje skutkiem refleksyjnego dialogu prowadzonego z samym sobą. Parafrazując Markus (1993), możemy powiedzieć, że jest swego rodzaju koordynowaniem , ja w myśli i pamięci”. Dialog ten w codziennym życiu przybiera różną postać, najczęściej pisania dzienników, pamiętników, opowiadań autobiograficznych itp. W ostatnich latach obserwuje się wzrost zainteresowań pisanymi narracjami, a inspirację dla większości studiów stanowią założenia filozofii hermeneutycznej Ricoeura (1991). Opowiadanie - rozumiane jako tekst - spełnia zdaniem Autora funkcję mediacyjna, pośrednicząc między człowiekiem, światem i innymi ludźmi. Świat, jednostka oraz inni ludzie to całość powiązana dialektycznymi związkami. Piszemy, by rozumieć i być zrozumianymi. Oznacza to, że każda forma rozumienia ma charakter narracyjny. Wszędzie tam, gdzie następuje rozumienie, istnieje ktoś, kto może o tym opowiedzieć. Obecny jest też przedmiot, którego to opowiadanie dotyczy.

Warto raz jeszcze przywołać stanowisko Jeremiasza Brunera, znanego przedstawiciela konstruktywizmu. Narracja stanowi dla niego odmianę myślenia (Bruner, 1986). Badacz twierdzi, że nie dysponujemy innym sposobem 
opisania przeżytego czasu. Narracja jest swoistym sposobem tworzenia świata. Opowieści o minionym czasie są też sposobem kreowania siebie. Sposobów wyrazu jest wiele, a dostarcza ich sama kultura. Zacytujmy słowa klasyka: „...w ostatecznym rozrachunku kulturowo ukształtowane procesy poznawcze i językowe, które kierują opowiadaniem auto narracji o życiu, osiagają moc strukturalizowania doświadczenia percepcyjnego, organizowania pamięci, segmentacji i celowego budowania samych »wydarzeń« z życia. W końcu my stajemy się autobiograficznymi narracjami, poprzez które opowiadamy o swoim życiu. A biorąc pod uwagę kulturowe ukształtowanie do którego się odwoływałem, stajemy się również wariantami duchowych form naszej kultury" (Bruner, 1990, s. 6).

Sprawozdania z własnego życia - swobodne lub kierowane pytaniami badacza - stanowią przykład złożonego dialogu, który toczy się między referującym, słuchającym i określonym otoczeniem społecznym. Pisanie ich sprzyja porządkowaniu, zrozumieniu i reinterpretacji doświadczeń. Poprzez tę formę wewnętrznej aktywności poznajemy lepiej uwarunkowania rozwoju, które możemy przepracować i wykorzystać w procesie kierowania własnym życiem. W dialogu z sobą samym zdobywamy stopniowo nowa perspektywę, stając się podmiotem i współautorem życia zakotwiczonego w czasie i przestrzeni.

SPOSÓB DOŚWIADCZANIA SIEBIE W CZASIE. Jeden z najnowszych nurtów badań metapoznawczych uwzględnia funkcjonowanie w czasie, możliwość sięgania pamięcią wstecz i rzutowania się w przyszłość. Nowatorski pomysł Stolarskiego i Witowskiej (2017) stanowi kontynuację i rozszerzenie koncepcji perspektyw czasowych Zimbardo i Boyda (2008). Ci ostatni wyróżnili sześć względnie stałych dyspozycji, za pomocą których można opisać funkcjonowanie ludzi w perspektywie czasowej: przeszłość negatywna, przeszłość pozytywna, teraźniejszość hedonistyczna, teraźniejszość fatalistyczna, przyszłość pozytywna i przyszłość negatywna. Chwilowa koncentracja na jednym z horyzontów temporalnych (przeszłość, teraźniejszość, przyszłość) rozumiana jest jako stan (Stolarski, Fieulaine, Zimbardo, 2018). Jednak doświadczenia życiowe oraz właściwości psychiki (np. temperamentu) mogą utrwalać tendencję jednostki do koncentrowania uwagi na jakichś horyzontach czasowych (Stolarski, Witowska, 2017). Tak kształtują się względnie stałe dyspozycje jednostki, a preferowanie perspektyw przyjmuje wówczas postać cechy.

Ważnym rozszerzeniem koncepcji perspektyw czasowych było wprowadzenie kategorii zrównoważonej perspektywy (balanced time perspective; Zimbardo, Boyd, 1999). Jest to umiejętność przełączania się pomiędzy perspektywami, 
odbywania swego rodzaju mentalnych podróży w czasie. Badania pokazały, że ułatwia ona adaptację (Stolarski, Wiberg, Osin, 2015). Okazało się na przykład, że osoby o zrównoważonym profilu perspektyw czasowych doświadczają niższego poziomu stresu oraz lęku i charakteryzuje ich wyższa satysfakcja w związkach (Stolarski, Wojtkowska, Kwiecińska, 2016).

Swobodne poruszanie się w czasie jest wskaźnikiem pewnej elastyczności i przypomina - per analogiam - giętkość strategiczną w zakresie posługiwania się strategiami uczenia się. Określono je mianem temporalnego metapoznania. Stolarski i Witowska (2017) nawiązują zatem do struktury metapoznania zaproponowanej przez Efklides (2008), wyodrębniając wiedzę, umiejętności i doświadczenia metakognitywne. Twierdzą, że świadome, intencjonalne przełączanie się pomiędzy perspektywami czasowymi jest w istocie procesem metapoznawczym i wiąże się z „monitorowaniem, gromadzeniem wiedzy i doświadczeń oraz świadomą samoregulacją w zakresie koncentracji na poszczególnych horyzontach czasowych" (Stolarski, Witowska, 2017, s. 16). Sednem temporalnego metapoznania pozostaje świadomość aktywnej perspektywy czasowej oraz intencjonalna regulacja przyjmowanych horyzontów.

\section{STRES INFORMACYJNY JAKO RODZAJ DOŚWIADCZENIA METAPOZNAWCZEGO.}

W niniejszym fragmencie nawiązuję do stwierdzeń sformułowanych na początku rozdziału. Subiektywny dyskomfort odczuwany przez wielu współczesnych żyjących w środowisku bogatym w informacje nazwałam przed laty stresem informacyjnym (Ledzińska, 2009; Ledzińska, w: Heszen, 2013). Powstaje on w sytuacjach zakłócenia podstawowej zasady życia, jaką jest wymiana energii, materii i informacji, nazywana metabolizmem energetyczno-informacyjnym (Kępiński, 2003). Wymiana ta ulega dziś niejednokrotnie zakłóceniu, co znajduje odzwierciedlenie w doświadczeniu. Dzieje się tak z co najmniej trzech powodów. Pierwszy to tempo transmisji sygnałów odbieranych przez człowieka, w porównaniu do szybkości pracy jego mózgu. Podczas gdy sprawność przekazywania informacji wzrosła o kilkanaście rzędów wielkości, mózg ludzki nie uległ zmianie i jest mechanizmem przekazywania sygnałów milion razy wolniejszym w porównaniu z nowoczesnym komputerem. Drugi powód wiąże się z postawa popularną zwłaszcza wśród młodych ludzi. Składa się na nią kilka elementów. Pierwszy to wydłużenie fazy pobierania informacji w stosunku do etapu przetwarzania. Jej odpowiednikiem - na płaszczyźnie metabolizmu energetycznego - byłaby przedłużona (ciagła) konsumpcja, pozbawiająca organizm możliwości strawienia i przyswojenia pokarmu. Dzieje się tak m.in. w wyniku specyficznego stosunku do treści - to drugie ogniwo charakteryzowanej 
postawy. Wielu traktuje informację jako wartość nadrzędną, usilnie jej poszukuje, przyjmuje często w sposób bezkrytyczny, a niekiedy utożsamia z wiedzą. Pogoń za nowinkami - nazwana przez Shenka (1997) strategia „,strusia pędziwiatra" - utrudnia refleksyjny wybór i przetworzenie odebranych informacji, połączenie z posiadaną wiedzą oraz skuteczne wykorzystanie. Podobne skutki przynosi - nagminne zwłaszcza wśród osób uczących się - gromadzenie kopii materiałów bez ich uważnej i niespiesznej lektury, określane przez Umberto Eco (2007) jako przejaw tzw. xero kultury. Trzeci powód związany jest z jednym $z$ ważnych następstw ekspansji technologii informacyjnej, a mianowicie lawinowym przyrostem danych. Technologia informacyjna ułatwia wyszukiwanie informacji, ich gromadzenie, przetwarzanie oraz przesyłanie na odległość. Nade wszystko jednak ułatwia wytwarzanie treści oraz ich upowszechnianie (Morbitzer, 2007). W rezultacie tych zmian mamy do czynienia z - niemającą swego odpowiednika w przeszłości - dysproporcją między informacją ujmowaną w wymiarze ilościowym a możliwościami jej obróbki.

Z hiperprodukcją treści powiązana jest ich wiarygodność. W toku ewolucji głównych sposobów komunikowania (mowa, pismo, druk, podłączony do Internetu komputer), obok zwiększania liczby informacji i łatwego doń dostępu, tracono stopniowo kontrolę nad jej obiegiem (Ledzińska, Postek, 2017). Na etapie pisma kontrolować można było, kto i z jaką informacją się zapoznaje. Autorzy ponosili za nią osobistą odpowiedzialność. Informacje będące w obiegu były cenzurowane i trafiały do wyznaczonych odbiorców. Wynalazek druku wiązał się z pewną utratą kontroli nad czytelnictwem, a masowa produkcja książek i ich niższe ceny skutkowały ułatwieniem dostępu do treści. Utracono więc możliwość decydowania o tym, kto zapoznaje się z informacją, nadal jednak można było sprawować kontrolę nad autorami i wytwarzaną przez nich treścią. Upowszechnienie Internetu i łatwość zamieszczania w nim treści pociagnęły za sobą utratę kontroli nad tym, kto jest autorem. Nie istnieją w tym względzie ograniczenia i dotyczy to wszystkich rodzajów danych. Najpopularniejsze dziś internetowe źródło informacji, czyli Wikipedia, cechuje swoboda zamieszczania treści. Są one rozsiane w sieci i zróżnicowane pod względem wiarygodności, co niekiedy nazywa się smogiem informacyjnym (Shenk, 1997; Szynkiewicz, 2014).

Dla indywidualnej oceny trudów selekcji i przetwarzania wielu szybko emitowanych treści proponowano wcześniej różne terminy, np. przeciążenie umysłu (Bawden, Robinson, 2009) lub określenia metaforyczne, jak library anxiety (Mellon, 1986). Trafnym zakotwiczeniem koncepcyjnym wydawała się być interpretacja syndromu przeżyć, na który składa się zaskoczenie wielością i róż- 
norodnością dostępnych danych, spośród których trzeba wybrać te istotne, prawdziwe i potrzebne, w kategoriach stresu psychologicznego (Ledzińska, 2009). Ujęcie to pozwalało wiązać nasilenie stresu z zasobami jednostki ujmowanymi m.in. jako preferowany sposób przetwarzania informacji. Z punktu widzenia podjętych rozważań napięcie towarzyszące egzystencji w środowisku bogatym w informacje odpowiada definicji doświadczenia metapoznawczego (Efklides, 2008), czyli subiektywnych doznań powstających między człowiekiem i podejmowanym przezeń zadaniem (selekcji informacji, ich integracji oraz włączenia w istniejący system wiedzy).

W świetle wyników badań informacyjny stres koreluje ze sposobem przetwarzania informacji. Poczucie stresu potęuje np. niska odporność na interferencję czy charakterystyczny sposób obróbki danych ujmowany m.in. na wymiarach stylów poznawczych: analityczny (przeciwieństwo syntetycznego) i konkretny (przeciwieństwo abstrakcyjnego). W obszarze funkcjonowania metapoznawczego silniejszy stres wiążę się natomiast z obecnością dysfunkcjonalnych przekonań oraz deficytami w zakresie kontroli uczenia się (słaba, sztywna, chwiejna). Oznacza to, że doświadczenia metapoznawcze związane są z umiejętnościami metakognitywnymi.

\section{PODSUMOWANIE: PRZYCZYNY POPULARNOŚCI BADAŃ NAD METAPOZNANIEM}

Łączącym ogniwem badań nad metapoznaniem jest koncepcja człowieka jako istoty aktywnej, tj. przetwarzającej informacje nie tylko o świecie zewnętrznym - przedmiotach, zjawiskach i ludziach, ale również o sobie samym. Przetwarzanie obejmuje odbiór informacji, ich rozumienie, refleksyjną ocenę, wykorzystanie w realizacji celów jednostkowych i społecznych. Deficyty w obszarze wiedzy, umiejętności i doświadczeń metakognitywnych pozwalają zrozumieć mechanizm powstawania niektórych zaburzeń, dostarczając przesłanek do ich korekty w ramach samowychowania i/lub terapii.

Odpowiadając na pytanie o prawdopodobne przyczyny popularności studiów nad metapoznaniem, wskazuję na grupe przesłanek historycznych oraz kulturowych. Do pierwszej zaliczam ekspansje poznawczego nurtu w psychologii, z jego koncepcja człowieka (Maruszewski, 2001; Miller, 2003; Sternberg, Sternberg, 2012). Drugie wiążę ze zmianami w kulturze czasów przełomu XX i XXI wieku. Wywołane rozwojem technologicznym, uaktualniły i wyeksponowały myślenie o człowieku w wymiarze efektywności jego działania. Ten złożony problem wymaga odrębnych analiz, a trudność zadania komplikuje 
dodatkowo niejednoznaczne rozumienie kultury (Kaczorowski, 2008). W potocznym rozumieniu jest nią całokształt duchowego i materialnego dorobku społeczeństw. Psychologowie nawiązujący do koncepcji dwóch warstw zjawisk kulturowych Stefana Ossowskiego (2000), za sedno kultury uznają dominujące wzory myślenia i zachowania. Niektórzy badacze współczesności uważają że dzisiejsza kultura jest podporządkowana wiodącej technice, czyli technologii informacyjnej (m.in. Postman, 2004). David Bolter (1990), autor tezy: ,jaka technika, taka kultura", twierdzi, że aktualna technika wyznacza perspektywę widzenia człowieka, a wielu jej użytkowników patrzy na innych niczym na maszynę, tj. przez pryzmat nowoczesnych urządzeń technicznych, ocenianych przede wszystkim pod kątem wydajności. Nie można wykluczyć, że troska o wzrost efektywności funkcjonowania ożywiła i zintensyfikowała studia nad metapoznaniem, ważnym wyznacznikiem skuteczności działania. Możliwa jest też szersza niż dotychczas zaproponowane odpowiedź na pytanie o popularność charakteryzowanego nurtu. Kategorie samopoznania, samokontroli, samoregulacji nie pojawiły się w XX wieku, a zainteresowanie nimi nie stanowi jedynie domeny dociekań naukowych. Idee te są dobrze znane od wieków w kręgu kultury europejskiej. Wszak na frontonie delfickiej świątyni Apolla wyryto tę najsławniejszą sentencję starożytności, znaną w wersji łacińskiej jako „cognosce te ipsum”. Stwierdzenie, że wszelka mądrość bierze początek w poznawaniu siebie nie było jedynym napisem na delfickim sanktuarium. Bielawski (2018) pisze o blisko 150 maksymach, które przetrwały do dziś w postaci znanych cytatów lub ich parafraz. Doceniamy ich treść i podziwiamy zwięzła formę: „znaj właściwy czas”, „,władaj sobą”, „ćwicz rozum”, „nic w nadmiarze”, „szanuj siebie”, „panuj nad wydatkami”, „żyj bez smutku”, „zmierzaj śmiało do kresu". Mamy zatem do czynienia nie tylko z ciagłością rozwoju badań, ale też z ciagłością refleksji nad człowiekiem, refleksji uwypuklającej ludzką racjonalność.

\section{BIBLIOGRAFIA}

Allport, G. W. (1960). Personality and social encounter. Selected essays. Boston: Beacon Press. Allport, G. W. (1988). Osobowość i religia. Warszawa: Instytut Wydawniczy „Pax”. Azevedo, R., Aleven, V. (red.). (2013). International handbook of metacognition and learning technologies. Nowy Jork: Springer.

Bąk, W. (2017). Standardy Ja. Hierarchiczny model samowiedsy. Warszawa: Liberi Libri. Bandura, A. (1997). Self-efficacy: The exercise of control. Nowy Jork: Freeman. 
Bawden, D., Robinson, L. (2009). The dark side of information: Overload, anxiety and other paradoxes and pathologies. Journal of Information Science, 35(2), 180-191. https://doi.org/10.1177/01655515080995781

Bielawski, K. (2018). Delficki trójnóg. Sentencje delfickie. Kraków: Wydawnictwo Uniwersytetu Jagiellońskiego.

Bolter, D. (1990). Człowiek Turinga: Kultura Zachodu w wieku komputera. Warszawa: Państwowy Instytut Wydawniczy.

Bowlby, J. (2007). Praymiazanie. Warszawa: Wydawnictwo Naukowe PWN.

Bruner, J. (1978). Poza dostarczone informacje. Warszawa: Państwowe Wydawnictwo Naukowe.

Bruner, J. (1986). Actual minds. Possible worlds. Harvard: University Press.

Bruner, J. (1990). Acts of meaning. Cambridge-Londyn: Harvard University Press.

Cantwell, R. H. (1997). Cognitive disposition and student nurses' appraisals of the learning environment. Issues in Education Research, 7(1), 19-36.

Cantwell, R. H., Moore, P. J. (1996). The development of measures of individual differences in self-regulatory control and their relationship to academic performance. Contemporary Educational Psychology, 21(4), 500-517. https://doi.org/101006/ ceps.1996.0034

Chuderski, A. (2010). Samokontrola: własności, mechanizmy i ograniczenia. Studia z. Kognitywistyki i Filozofii Umystu, 4(1), 27-51.

Clark, D. A., de Silva, P. (1985). The nature of depressive and anxious, intrusive thoughts: Distinct or uniform phenomena? Behaviour Research and Therapy, 23(4), 383-393. https://doi.org/10.1016/0005-7967(85)90166-4

Clark, D. A., Rhyno, S. (2005). Unwanted intrusive thoughts in nonclinical individuals. W: D. A. Clark (red.), Intrusive thoughts in clinical disorders: Theory, research and treatment (s. 1-29). Nowy Jork: Guilford Press.

Cornoldi, G. (2010). Metacognition, intelligence, and academic performance. W: H. S. Waters, W. Schneider (red.), Metacognition, strategy use, and instruction (s. 257-277). Nowy Jork: Guilford Press.

Czerniawska, E. (1999). Dynamika zachowań strategicznych w uczeniu sie z. tekstów podrecznikowych. Warszawa: Wydawnictwo Uniwersytetu Warszawskiego.

Czerniawska, E. (2006). Metapoznanie a inteligencja - przegląd poglądów teoretycznych i wyników badań. Przeglad Psychologiczny, 49(2), 119-140.

Dagenbach, D., Carr, T. H. (1994). Inhibitory processes in attention, memory, and language. San Diego: Academic Press.

Dragan, M. (2016). Picie problemowe młodych kobiet. Rola niekorzystnych doświadczeń i samoregulacji emocji. Warszawa: Wydawnictwo Naukowe Scholar.

Dunlosky, J., Metcalfe, J. (2009). Metacognition. Waszyngton: Sage. 
Dymkowski, M. (1993). Poznawanie siebie. Umotywowane sprawdziany samowiedzy. Warszawa: Wydawnictwo Instytutu Psychologii PAN.

Eco, U. (2007). O bibliotece. Warszawa: Świat Książki.

Efklides, A. (2008). Metacognition: Defining its facets and levels of functioning in relation to self-regulation and co-regulation. European Psychologist, 13(4), 277-287. https://doi.org/10.1027/1016-9040.13.4.277

Engle, R. W., Conway, A. R. A., Tuholski, S. W., Shisler, R. J. (1995). A resource account of inhibition. Psychological Science, 6(2), 122-125. https://doi. org./10.1111/j.1467-9280.1995.tb00318.x

Flavell, J. H. (1979). Metacogniton and cognitive monitoring: A new era of cognitive inquiry. American Psychologist, 34(10), 906-911. https://doi.org/10.1037/0003066X.34.10.906

Gratz, K. L., Roemer, L. (2004). Multidimensional assessment of emotion regulation and dysregulation: Development, factor structure, and initial validation of the difficulties in Emotion Regulation Scale. Journal of Psychopathology and Behavioral Assessment, 26, 41-54. http://dx.doi.org./10.1023/B:JOBA.0000007455.08539.94

Greenberg, J., Arndt, J. (2011). Terror management theory. W: P. Van Lange, A. Kruglanski, E. Higgins (red.), The handbook of theories of social psychology. Londyn: Sage Publications.

Gross, J. J. (1998). The emerging field of emotion regulation: An integrative review. Review of General Psychology, 2(3), 271-299. https://doi.org./10.1037./10892680.2.3.271

Gross, J. J. (1999). Emotion regulation: Past, present, future. Cognition \& Emotion, 13(5), 551-573. https://doi.org./10.1080/0269999399379186

Hacker, D. J., Dunlosky, J., Graesser, A. C. (red.). (2009). Handbook of metacognition in education. Nowy Jork: Routledge.

Heidegger, M. (2000). Co zwie sie myśleniem? Warszawa: Wydawnictwo Naukowe PWN. Heszen, I. (2013). Psychologia stresu. Warszawa: Wydawnictwo Naukowe PWN.

James, W. (1890). The principles of psychology. Nowy Jork: Henry Holt and Company.

Kaczorowski, B. (2008). Epoki i kierunki w kulturze. Warszawa: Wydawnictwo Naukowe PWN.

Kempisty, M. (red.). (1973). Mały stownik cybernetyczny. Warszawa: Wiedza Powszechna. Kępiński, A. (2003). Melancholia. Warszawa: PZWL.

Kofta, M. (2001). Poczucie kontroli, złudzenia na temat siebie, a adaptacja psychologiczna. W: M. Kofta, T. Szustrowa (red.), Ztudzenia, które pozwalaja żyć (s. 199-225). Warszawa: Wydawnictwo Naukowe PWN. 
Koriat, A. (2007). Metacognition and consciousness. W: D. Zelazo, M. Moscovitch, E. Thompson (red.), The Cambridge handbook of consciousness (s. 289-325). Londyn: Cambridge University Press.

Kozielecki, J. (1986). Psychologiczna teoria samowiedzy. Warszawa: Wydawnictwo Naukowe PWN.

Krzyżewski, K. (2008). Samoregulacja i samokontrola jako przedmiot psychologii. W: A. Niedźwieńska (red.), Samoregulacja w poznaniu i dżałaniu (s. 17-32). Kraków: Wydawnictwo Uniwersytetu Jagiellońskiego.

Ledzińska, M. (1996). Przetwarzanie informacji przez uczniów o zróżnicowanym poziomie zdolności a ich postępy szkeolne. Warszawa: Oficyna Wydawnicza Wydziału Psychologii UW.

Ledzińska, M. (2009). Człowiek wspótczesny w obliczu stresu informacyjnego. Warszawa: Wydawnictwo Instytutu Psychologii PAN.

Ledzińska, M., Czerniawska, E. (2011). Psychologia nauczania. Ujecie poznawcze. Warszawa: Wydawnictwo Naukowe PWN.

Ledzińska, M., Postek, S. (2017). From metaphorical information overflow and overload to real stress: Theoretical background, empirical findings and applications. European Management Journal, 35(6), 785-793. https://doi.org/10.1016/j. emj.2017.07.002

Ledzińska, M., Zajenkowski, M., Stolarski, M. (2013). Temperament i poznanie. Energetyczne $i$ czasowe zaplecze umystu. Warszawa: Wydawnictwo Naukowe Scholar.

Limont, W. (2010). Uczeń zdolny. Jak go rozpoznać i jak z nim pracować. Gdańsk: Gdańskie Wydawnictwo Psychologiczne.

Littleton, K., Wood, C., Kleine Staarman, J. (2010). International handbook of psychology in education. Bingley: Emerald.

Maciuszek, J. (2007). Paradoksalne efekty prób umysłowej kontroli - zarys teorii Daniela Wegnera. Annales Academiae Paedagogicae Cracoviensis. Studia Psychologica, 2, 104-118.

Main, M., Hesse, E., Goldwyn, R. (2008). Studying differences in language usage in recounting attachment history: An introduction to the AAI. W: H. Steele, M. Steele (red.), Clinical applications of the Adult Attachment Interview (s. 31-68). Nowy Jork: The Guilford Press.

Main, M., Kaplan, N., Cassidy, J. (1985). Security in infancy, childhood, and adulthood: A move to the level of representation. Monographs of the Society for Research in Child Development, 50(1-2), 66-104. https://doi.org/10.2307/3333827

Main, M., Solomon, J. (1986). Discovery of a new, insecure disorganized/disoriented attachment pattern. W: T. B. Brazelton, M. Yogman (red.), Affective development infancy (s. 95-125). Norwood: Ablex. 
Markus, H. (1993). Ja w myśli i pamięci. W: T. Maruszewski (red.), Poz̨nanie, afeket, zachowanie (s. 102-130). Warszawa: Wydawnictwo Naukowe PWN.

Martinez, M. E. (2006). What is metacognition? Phi Delta Kappan, 87(9), 696-699. https:// doi.org/10.1177/003172170608700916

Maruszewski, T. (2001). Psychologia poznania. Gdańsk: Gdańskie Wydawnictwo Psychologiczne.

Matczak, A. (2006). Natura i struktura inteligencji emocjonalnej. Psychologia, Etologia, Genetyka, 13, 59-87.

Matczak, A., Knopp, K. (2013). Znaczenie inteligencji emocjonalnej w funkcjonowaniu człowieka. Warszawa: Liberi Libri.

Mayer, J. D., Salovey, P. (1999). Czym jest inteligencja emocjonalna? W: P. Salovey, D. J. Sluyter (red.), Rozwój emocjonalny a inteligencja emocjonalna (s. 23-69). Poznań: Dom Wydawniczy Rebis.

Mellon, C. A. (1986). Library anxiety: A grounded theory and its development. College \& Research Libraries, 47(2), 160-165.

Miller, G. A. (2003). The cognitive revolution: A historical perspective. Trends in Cognitive Science, 7(3), 141-144. https:/ / doi.org/10.1016/S13.64-6613(03)00029-9

Morbitzer, J. (2007). Edukacja wspierana komputerowo a bumanistyczne wartości pedagogiki. Kraków: Wydawnictwo Naukowe Akademii Pedagogicznej.

Nęcka, E., Orzechowski, J., Szymura, B. (2013). Psychologia poznawcza. Warszawa: Wydawnictwo Naukowe PWN.

Nelson, T. O. (1996). Consciousness and metacognition. American Psychologist, 51, 102-116. https://doi.org/10.1037/0003-066X.51.2.102

Nelson, T. O., Narens, L. (1994). Why investigate metacognition? W: J. Metcalfe, A. P. Shimamura (red.), Metacognition: Knowing about knowing (s. 1-25). Cambridge: Cambridge University Press.

Norman, E., Pfhul, G., Saele, R. G. (2019). Metacognition in psychology. Review of General Psychology, 23(4), 403-424. https://doi.org/10.1177/1089268019883821

Ossowski, S. (2000). Z zagadnień psychologii społecænej. Warszawa: Wydawnictwo Naukowe PWN.

Postman, N. (2004). Technopol: Triumf techniki nad kulturq. Warszawa: Państwowy Instytut Wydawniczy.

Rachlin, H. (2000). The science of self-control. Cambridge: Harvard University Press.

Rachman, S., de Silva, P. (1978). Abnormal and normal obsessions. Behaviour Research and Therapy, 16(4), 233-248. https://doi.org/10.1016/0005-7967(78)90022-0

Ricoeur, P. (1991). Narrative identity. Philosophy Today, 35(1), 73-81. https://doi. org/105840/philtoday199135136 
Salovey, P., Detweiler-Bedell, B. T., Detweiler-Bedell, J. B., Mayer, J. D. (2008). Emotional intelligence. W: M. Lewis, J. M. Haviland-Jones, L. Feldman Barrett (red.), Handbook of emotions (s. 533-547). Nowy Jork-Londyn: The Guilford Press.

Salovey, P., Mayer, J. D. (1990). Emotional intelligence. Imagination, Cognition, and Personality, 9(3), 185-211. https://doi.org/10.2190/DUGG-P24E-52WK-6CSDG

Schwarz, D. L., Tsang, J. M., Blair, K. P. (2016). ABC's of how we learn. Nowy JorkLondyn: W. W. Norton \& Company.

Sękowski, A. (2000). Osiagnięcia uczniów zdolnych. Lublin: Wydawnictwo KUL.

Serra, M. J., Metcalfe, J. (2009). Effective implementation of metacognition. W: D. J. Hacker, J. Dunlosky, A. C. Graesser (red.), Handbook of metacognition in education (s. 278-297). Nowy Jork: Routledge.

Shenk, D. (1997). Data smog: Surviving the information glut. Londyn: Abacus.

Sternberg, R. (1985). Beyond IQ. A triarchic theory of human intelligence. Cambridge: Cambridge University Press.

Sternberg, R. J. (2001). Próba weryfikacji teorii inteligencji sprzyjającej powodzeniu życiowemu poprzez operacje konwergencyjne. Przeglad Psychologiczny, 44(4), 375405.

Sternberg, R. J. (2002). Raising the achievement of all students. Teaching the successful intelligence. Educational Psychology Review, 14, 383-393. https://doi. org/10.1023/A: 1020601027773

Sternberg, R. J. (2005a). The theory of successful intelligence. Interamerican Journal of Psychology, 39(2), 189-202.

Sternberg, R. J. (2005b). The WISC model of giftedness. W: R. J. Sternberg, J. E. Davidson (red.), Conceptions of giftedness (s. 327-342). Londyn-Nowy Jork: Cambridge Press.

Sternberg, R. J. (red.). (2004). International handbook of intelligence. Nowy Jork: Cambridge University Press.

Sternberg, R. J., Sternberg, K. (red.). (2012). Cognitive psychology. Belmont: Wadsworth.

Stolarski, M., Fieulaine, N., Zimbardo, P. G. (2018). Putting time in a wider perspective: The past, the present and the future of time perspective theory. W: V. Zeigler-Hill, T. K. Shackelford (red.), The SAGE handbook of personality and individual differences (s. 592-628). Thousand Oaks: Sage Publishing.

Stolarski, M., Wiberg, B., Osin, E. (2015). Assessing temporal harmony: The issue of a balanced time perspective. W: M. Stolarski, N. Fieulaine, W. van Beek (red.), Time perspective theory: Review, research, and application (s. 57-71). Cham: Springer International Publishing. 
Stolarski, M., Witowska, J. (2017). Balancing own time perspective from aerial view: Metacognitive processes in temporal framing. W: A. Kostić, D. Chadee (red.), Time perspective. Theory and practice (s. 117-141). Londyn: Palgrave Macmillan.

Stolarski, M., Wojtkowska, K., Kwiecińska, M. (2016). Time for love: Partners' time perspectives predict relationship satisfaction in romantic heterosexual couples. Time \& Society, 25(3), 552-574. https:/ / doi.org/10.1177/0961463X15596703

Szynkiewicz, M. (2014). Metafora smogu informacyjnego a procesy informacyjne. Studia Metodologiczne, 32, 65-77.

Śmieja, M. (2018). W zwiqzkeu z inteligencja emocjonalnq. Kraków: Wydawnictwo Uniwersytetu Jagiellońskiego.

Śmieja, M., Orzechowski, J. (red.). (2008). Inteligencja emocjonalna. Fakty, mity, kontrowersje (s. 46-61). Warszawa: Wydawnictwo Naukowe PWN.

Świerżewska-Chadaj, D., Ledzińska, M. (2017). Stary problem w nowym ujęciu: związki między inteligencją i samoregulacją w uczeniu się a osiagnięciami w nauce szkolnej. Psychologia - Etologia - Genetyka, 35, 45-68.

Vohs, K. D., Baumeister, R. F. (red.). (2017). Handbook of self-regulation. Research, theory and application. Nowy Jork: Guilford Press.

Wegner, D., Wenzlaff, R. (1996). Mental control. W: T. Higgins, A. Kruglanski (red.), Social psychology: Handbook of basic mechanism and processes (s. 466-492). Nowy Jork: Guilford Press.

Wells, A., Matthews, G. (1994). Attention and emotion: A clinical perspective. Hove: Lawrence Erlbaum.

Zimbardo, P. G., Boyd, J. N. (1999). Putting time in perspective: A valid, reliable individual-difference metric. Journal of Personality and Social Psychology, 77(6), 1271-1288. https://doi.org/10.1037/0022-3514.77.6.1271

Zimbardo, P. G., Boyd, J. N. (2008). The time paradox. Nowy Jork: Free Press. 


\section{9.}

\section{Inteligentny sport: o związkach inteligencji z aktywnością fizyczną i poziomem wykonania sportowego}

Wojciech Waleriańczyk (iD) https://orcid.org/0000-0003-2421-660X

Uniwersytet Warszawski, Wydział Psychologii

wojciech.walerianczyk@psych.uw.edu.pl

Maciej Stolarski (iD https://orcid.org/0000-0003-1490-357X

Uniwersytet Warszawski, Wydział Psychologii 


\section{WPROWADZENIE}

Czym wyróżniają się najlepsi sportowcy? Jakim cechom możemy przypisać ich sukces? Na takie pytania postanowili odpowiedzieć Gould, Diffenbach i Moffett (2002). Za punkt wyjścia przyjęli treść wywiadów przeprowadzonych ze zdobywcami złotych medali podczas Igrzysk Olimpijskich. Zaangażowali także ich trenerów oraz członków bliskiej rodziny. Pośród 12 czynników w ich opinii niezbędnych do osiąnnięcia sukcesu w sporcie znalazły się:

- umiejętność radzenia sobie ze stresem (the ability to cope with and control anxiety),

- pewność siebie (confidence),

- odporność psychiczna (mental toughness/resiliency),

- umiejętność koncentracji i filtrowania dystraktorów (the ability to focus and block out distractions),

- gotowość do podjęcia rywalizacji (competitiveness),

- etos pracy (a hard-work ethic),

- umiejętność wyznaczania i osiagania celów (the ability to set and achieve goals),

- gotowość do nauki (coachability),

- wysoki poziom wiary w sukces (bigh levels of dispositional hope),

- optymizm (optimism),

- perfekcjonizm adaptacyjny (adaptive perfectionism),

- sportowa inteligencja (sport intelligence).

I właśnie ostatni z wymienionych elementów, a więc inteligencja krystalizująca się w kontekście sportu, okazał się dla autorów zaskoczeniem, jako że nie pojawiał się w ich wcześniejszych badaniach. Poszukując informacji dotyczących badań nad rolą inteligencji w sporcie, można zauważyć, że samo sformułowanie ,inteligencja” w kontekście sportu pojawia się zaskakująco rzadko (a do tego głównie w wyrażeniu ,inteligencja emocjonalna”; zob. Laborde, Dosseville, Allen, 2016), mimo że, polegając na intuicji, moglibyśmy oczekiwać dużego nasycenia tego obszaru badawczego. W niniejszym rozdziale podejmie- 
my próbę przeglądu badań nad inteligencją w kontekście sportu, prezentując przy tym studia dotyczące zarówno znaczenia inteligencji dla funkcjonowania w sporcie, jak i zależności odwrotnej, czyli wpływu, jaki uprawianie sportu może wywierać na zdolności poznawcze.

\section{ZNACZENIE INTELIGENCJI DLA POZIOMU WYKONANIA SPORTOWEGO}

CZY ISTNIEJE „SPORTOWA INTELIGENCJA”? We wspomnianym wyżej badaniu, Gould i in. (2002) nie podjęli się sformułowania dokładnej definicji sportowej inteligencji - pojęcie to miało być raczej szeroką kategoria, obejmującą te spośród wyróżnionych we wspomnianych powyżej wywiadach „czynników sukcesu", które posiadały komponentę poznawcza. Należały do nich: umiejętność analizowania sytuacji (the ability to analyze), kreatywność (being innovati$v e$ ), podejmowanie odpowiednich decyzji (making good decisions), zrozumienie wymagań stawianych przez sport na najwyższym poziomie (understanding the nature of elite sport) oraz zdolność szybkiego przyswajania nowych informacji i umiejętności (being a quick learner). Dodatkowo badacze zwrócili też uwagę na kluczową umiejętność selekcji wartościowych informacji, przy jednoczesnym odrzucaniu tych mniej użytecznych. Wiele spośród wymienionych tu komponentów sportowej inteligencji posiada swoje odpowiedniki w klasycznych ujęciach inteligencji (por. Nęcka, 2005) - dotyczy to w sposób szczególny zdolności do rozumowania i szybkiego uczenia się.

\section{ZNACZENIE ZDOLNOŚCI POZNAWCZYCH W KONTEKŚCIE WYKONANIA SPORTO-}

WEGO. Podejście zaproponowane przez zespół Goulda (Gould i in., 2002) możemy określić mianem introspekcyjno-obserwacyjnego, bazuje ono bowiem głównie na subiektywnych obserwacjach, odczuciach i przekonaniach osób powiązanych ze sportem wyczynowym. Bez watpienia jest ono wartościowe, jednak wskazane jest podejść do zagadnienia również od drugiej strony: analizując specyfikę aktywności sportowej z perspektywy procesów poznawczych. Przeglądu takiego dokonali Tenenbaum i Bar-Eli (1995), formułując ogólny model ilustrujący rolę poszczególnych zdolności poznawczych w sytuacji wykonania sportowego (zob. rysunek 1).

W modelu tym ostatnie ogniwo procesu inteligentnego zachowania stanowi, będąca istotą sportowego sukcesu, adekwatna reakcja motoryczna. Poprzedzaja ją dwie fazy przetwarzania informacji. Na pierwsza z nich, określaną mianem „wejścia”, składają się trzy podstawowe procesy: (1) kluczowa w nie- 
mal każdej dziedzinie sportu koncentracja uwagi, (2) istotna przede wszystkim w sportach wymagających przewidywania zachowania rywali antycypacja oraz (3) fundamentalne przede wszystkim w sportach najbardziej dynamicznych, bazujacych na odpowiedniej reakcji na zmiany w polu rozgrywki przeszukiwanie wzrokowe. Pierwszy i trzeci z wymienionych procesów są ze sobą nierozerwalnie powiązane i maja za zadanie dostarczyć jednostce, w jak najkrótszym czasie, możliwie trafnych i istotnych informacji dotyczących aktualnej sytuacji. Antycypacja z kolei jest procesem złożonym. Z jednej strony, dotyczy ogólnego przygotowania do tego, co za chwilę nastąpi: może zatem poprzedzać lub niejako prymować wzmożoną koncentrację uwagi i kierować ją na określone źródła informacji (w piłce nożnej byłaby to np. obserwacja ułożenia stopy i/ lub bioder wykonawcy rzutu karnego przez bramkarza przygotowującego się do interwencji). Jednocześnie dzięki zdolności do antycypacji jednostka może odnieść pozyskane z wykorzystaniem dwóch pozostałych procesów informacje do posiadanych doświadczeń. I tu przechodzimy do drugiego etapu wyróżnionego przez Tenenbauma i Bar-Eliego (1995) - przetwarzania. Pobrane w fazie „wejścia” informacje daja podstawę do rozwiązania problemu, którym jest podjęcie decyzji odnośnie najbardziej adekwatnego czy też skutecznego rozwiązania. Dzięki funkcjonowaniu pamięci bezpośredniej w tej fazie generowane są alternatywne rozwiązania (np. pozostać w miejscu, czy wykonać ruch w lewą stronę?). Co istotne, na tym etapie angażowane są również rozwinięte przez danego sportowca nawyki, zdobyte wcześniej informacje przechowywane w pamięci długotrwałej (np. w który róg bramki zazwyczaj uderza piłkę dany zawodnik). W oparciu o wiedzę (w dużej mierze utajona) i doświadczenie danego zawodnika, w połączeniu $\mathrm{z}$ informacjami dotyczącymi aktualnej sytuacji, w fazie „wejścia” podejmowana jest decyzja odnośnie najbardziej adekwatnego zachowania, za którą idzie odpowiednia reakcja motoryczna (i/ lub poznawcza, uruchamiając często cały proces od początku, w celu przygotowania kolejnej odpowiedzi, np. na reakcję rywala). 


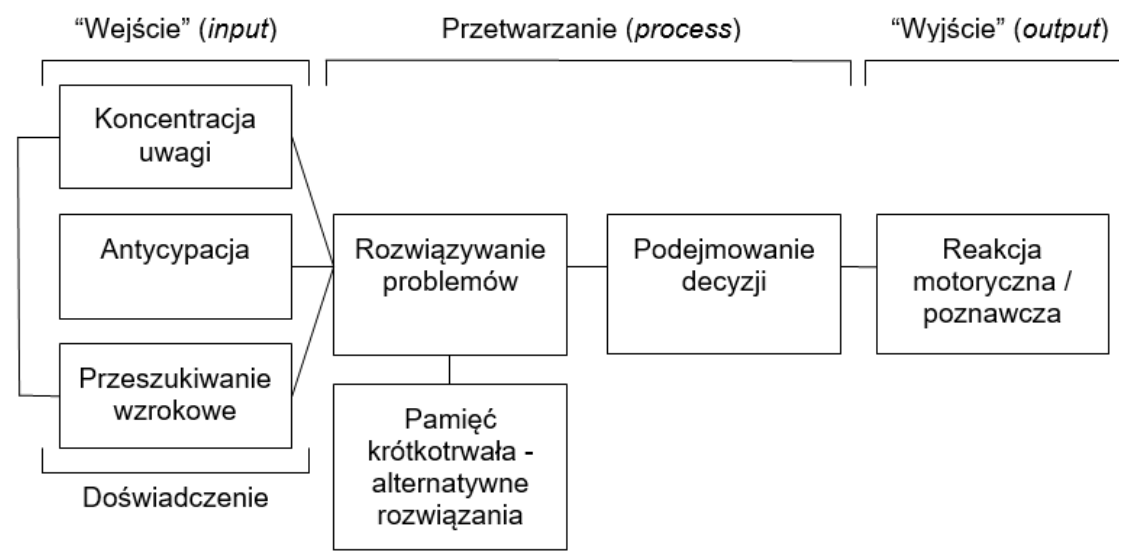

Rysunek 1. Model ilustrujacy przebieg dziatania komponentów percepcyjnych (takich jak uwaga, koncentracja, wrokowe poszukiwanie wskarówek oraz antycypacja nadchodracych uydarzeń) podczas wysitku fisycznego i ich wptyw na pryetwarzanie informaci do momentu wykonania reakcji motorycznej (por. Tenenbaum, Bar-Eli, 1995, s. 694).

Jak widać, cały proces, choć zazwyczaj przebiega w ułamkach sekund, jest niezwykle złożony i często wymaga zaangażowania maksimum zasobów poznawczych jednostki. Doskonałym przykładem badań, dowodzących zasadności powyższego modelu, sa studia nad znaczeniem roli czasu reakcji i szybkości podejmowania decyzji w sporcie. Jak wskazują dane empiryczne, istnieją wyraźne zależności pomiędzy szybkością przetwarzania informacji a poziomem inteligencji (Sheppard, Vernon, 2008). Szybkość mentalna jest, obok sprawności systemu poznawczego, ujmowana jako jeden z centralnych komponentów inteligencji (por. Nęcka, 2005). Tenisista, odbierając zagranie przeciwnika, przez około 500-600 ms czasu lotu piłki doświadcza niepewności odnośnie rzeczywistej prędkości i kierunku jej poruszania się. W tym czasie musi zaplanować odpowiednią reakcję. Zważywszy na szybkość reakcji motorycznej człowieka, rzeczywisty czas na podjęcie decyzji dotyczącej tego, jaki return zagrać, zajmuje między 30 a 50 milisekund (Abernethy, 1991)! Czołowi gracze w tak krótkim czasie są w stanie wybrać najlepszą możliwą reakcje spośród dostępnych w repertuarze zapisanym w pamięci długotrwałej w zdecydowanej większości przypadków (Tenenbaum, Bar-Eli, 1995). Co ciekawe, wśród najbardziej zaawansowanych zawodników sama szybkość reakcji nie ma tak wielkiego znaczenia jak u nowicjuszy (Abernethy, Russell, 1984; McLeod, 1987). Wydaje się, iż kluczową rolę w przypadku „ekspertów” odgrywać może umiejętność przewidywania lotu piłki już w oparciu o najwcześniejsze wska- 
zówki płynące z początkowych składowych toru lotu piłki, a także ułożenia rakiety czy ruchu przeciwnika. Tym samym gracze ci zyskuja zdecydowanie więcej czasu na przygotowanie odpowiedniego zagrania, a minimalne różnice w czasie reakcji prostej przestają być już tak bardzo istotne.

Zdolności do antycypacji i łączenia bieżących danych wizualnych z informacjami płynącymi ze zdobytego doświadczenia są zatem tym, co odróżnia mistrzów od dobrych sportowców. Jednocześnie wybitni gracze, wskutek długotrwałego, wieloletniego treningu, rozwijają unikalne struktury neurologiczne, pozwalające na przewidywanie znanych lub podobnych wydarzeń ze zwiększonym prawdopodobieństwem. Struktury te, określane mianem schematu gry (game schema), pozwalają im na rozumienie, pamiętanie i przewidywanie skutków określonych działań, uderzeń, zagrań itp. na poziomie niedostępnym dla początkującego gracza. W efekcie działania owej „utajonej inteligencji” ich zależność od bardzo szybkich reakcji (które, co istotne, są często obarczone większym ryzykiem) staje się znacznie mniejsza (McLeod, Jenkins, 1991). Tym samym wydaje się, że choć na początkowych etapach rozwoju sportowców tzw. płynne zdolności intelektualne mogą mieć duże znaczenie, wraz z nabywaniem doświadczenia coraz istotniejsze stają się konkretne mechanizmy, rozwinięte automatyzmy, a także zdolności poznawcze bezpośrednio powiązane z zadaniami poznawczymi typowymi dla uprawianej dyscypliny sportu, które, za Cattellem (1963), określić mianem zdolności skrystalizowanych (zob. dalej).

Model Tenenbauma i Bar-Eliego (1995) uwypukla fundamentalną rolę procesów uwagowych (takich jak efektywne kierowanie uwagą i utrzymywanie koncentracji) oraz przetwarzania informacji (wykorzystując mechanizmy pamięci roboczej i krótkotrwałej) w tym, co określają mianem ,inteligentnego zachowania motorycznego" (intelligent motor behavior). Tym samym inteligencja motoryczna wydaje się angażować dokładnie te same mechanizmy, co inteligencja ogólna (por. Nęcka, 2005). Kontekst sportu i powiązanej z nim aktywności fizycznej/ruchowej jest jednym z wielu różnych kontekstów czy obszarów funkcjonowania człowieka, w którym moga przejawiać się zdolności poznawcze. Idąc tym tropem i opierając się o klasyczne rozróżnienie na inteligencję płynną i skrystalizowaną (Cattell, 1963), możemy uznać, że wskutek akumulacji doświadczeń i rozwijania konkretnych umiejętności motorycznych, kompetencji i wiedzy niezbędnej do osiagania wysokich wyników w sporcie, wrodzone predyspozycje związane z szybkością i efektywnością przetwarzania informacji zostaja niejako „przekute” na konkretne zdolności związane z efektywnością funkcjonowania w kontekście wykonania sportowego. Również Howard Gardner w swojej koncepcji inteligencji wielorakich (Gardner, 
1983), pomimo odmiennego podejścia do struktury inteligencji ${ }^{3}$, twierdzi, iż inteligencja kinestetyczna (a dokładniej cielesno-kinestetyczna - bodily-kinesthetic), dotyczy de facto efektywności w sprawowaniu kontroli nad ruchami ciała oraz koordynacji reakcji kinestetycznych w odpowiedzi na dynamiczne zmiany w otoczeniu. Jego sposób rozumienia tej grupy zdolności wskazuje na szczególną rolę interakcji talentu i doświadczenia, które wydają się kluczowe w odniesieniu do osiagnięcia najwyższych poziomów tego rodzaju inteligencji. Tym samym tezy Gardnera wydają się spójne z opisanymi powyżej wynikami badań, wskazującymi na nadrzędną rolę doświadczenia nad predyspozycjami intelektualnymi w kształtowaniu sportowej inteligencji.

Z niewiadomych przyczyn w literaturze z zakresu badań nad inteligencja oraz w pracach z obszaru psychologii sportu bardzo rzadko wykorzystywano pomiar inteligencji per se. Tym niemniej istnieje dość liczna grupa badań wskazujących na wyraźne zależności różnic indywidualnych w zakresie funkcjonowania poznawczego z poziomem wykonania sportowego. Na przykład Vestberg, Reinebo, Maurex, Ingvar i Petrovic (2017) wykazali, że młodzi piłkarze, występując na najwyższych szczeblach rozgrywek, osiagali w testach angażujących funkcje wykonawczej (np. w zadaniu n-wstecz mierzącym pamięć robocza) wyniki znacząco wyższe od normy populacyjnej, a ich przewaga wahała się między 0,49 a 0,86 odchylenia standardowego. Jednocześnie już w obrębie rzeczonej grupy piłkarzy, wyniki w testach poznawczych okazały się istotnym i wyraźnym predyktorem liczby strzelonych goli (związek wynosił $r=$ 0,55 dla zagregowanego wskaźnika wykonania zadań poznawczych). Co ważne, znaczenie tego typu zdolności poznawczych wydaje się być zdecydowanie większe w tzw. „otwartych” dyscyplinach sportu, które wymagają nieustannej koncentracji uwagi, kontroli licznych zmiennych sytuacyjnych oraz adaptacji do zmieniających się warunków rywalizacji (Williams, Ford, Eccles, Ward, 2011). $\mathrm{Na}$ pierwszy plan wysuwają się zatem dyscypliny o wysokiej dynamice i zmienności, w których sukces wymaga nieustannej analizy gry przeciwnika i okazania się ,sprytniejszym” od niego - takich jak tenis, gry zespołowe czy sporty walki. Inne dyscypliny moga charakteryzować się odmiennymi wymaganiami poznawczymi. Istnieją prace analizujące unikalne zdolności wybitnych graczy: np. słynny szkocki snookerzysta Stephen Hendry jest w stanie jednocześnie objąć swoją uwagą wzrokową zarówno biała, jak i kolorową bilę, a także kie-

3 Gardner (1983) twierdzi, iż każdy rodzaj inteligencji stanowi odrębną grupę zdolności; w przeciwieństwie do autorów postulujących hierarchiczną strukturę intelektu, Gardner wyróżnia szereg osobnych typów inteligencji. 
szeń, do której skieruje tę drugą (por. Memmert, 2009). Warto w tym miejscu podkreślić, że wysoki poziom zdolności poznawczych może być przydatny nie tylko w sportach dynamicznych, ale również tych, które wymagają ekstremalnie wysokiego poziomu kontroli uwagowej, takich jak wspomniany snooker, strzelectwo, lucznictwo czy curling (Memmert, 2009).

Inne badania dostarczają dalszych dowodów na zasadność tezy o szczególnej roli funkcji wykonawczych w rozmaitych dyscyplinach sportu, takich jak piłka nożna, piłka ręczna czy koszykówka (Huijgen i in., 2015; Policastro, Accardo, Marcovich, Pelamatti, Zoia, 2018; Verburgh, Scherder, van Lange, Oosterlaan, 2014; Wagner, Finkenzeller, Würth, von Duvillard, 2014). Roca, Ford i Memmert (2018) wskazali na jeden z potencjalnych mechanizmów wpływu funkcji wykonawczych na poziom wykonania sportowego, dowodząc, że różnice indywidualne w zakresie mechanizmów kontroli uwagowej moga znacząco wpływać na poziom boiskowej kreatywności wśród dorosłych piłkarzy. Choć w większości spośród omówionych wyżej badań nie dokonywano pomiaru inteligencji per se, a przedmiotem analizy były rozmaite wskaźniki funkcji wykonawczych, to zważywszy na fundamentalną rolę tych ostatnich w kształtowaniu się różnic indywidualnych w zakresie inteligencji ogólnej (Nęcka, 2005), ich wyniki możemy traktować jako dowód trudnej do przecenienia roli intelektu w kontekście poziomu wykonania sportowego.

\section{INTELEKT TO NIE WSZYSTKO: O INTERAKCJI EMOCJI I INTELIGENCJI W SPORCIE.}

Omawiając rolę czynników stricte intelektualnych w rozwoju sportowej inteligencji, nie sposób pominąc faktu, iż sytuacja współzawodnictwa sportowego wiąże się zazwyczaj z bardzo silnym pobudzeniem emocjonalnym. To ostatnie zaś, jeśli okaże się niedopasowane do zadania (tzn. zbyt wysokie lub - niekiedy - zbyt niskie), może znacząco obniżyć poziom wykonania sportowego (Jones, 2003; Wagstaff, 2014), również wskutek ograniczenia możliwości wykorzystania posiadanych zasobów poznawczych (zob. np. Humphreys, Revelle, 1984). W dalszej części niniejszego rozdziału skupimy się na zmiennej, która choć z jednej strony stanowi jeden z rodzajów inteligencji ogólnej, to jednocześnie wywiera przemożny wpływ na jakość funkcjonowania emocjonalnego.

Chociaż w historii rozwoju psychologii naukowej emocje i intelekt wielokrotnie były sobie przeciwstawiane, ostatnie dwie dekady XX wieku przyniosły ogromną liczbę badań naukowych dowodzących, iż do efektywnej adaptacji do zmieniającego się środowiska potrzebujemy obydwu tych filarów ludzkiej psychiki (zob. np. Salovey, Mayer, 1990). Swoistą emanacją wzmożonej koncentracji badaczy na „pograniczu” emocji i poznania stały się teorie inteligen- 
cji emocjonalnej - konstruktu, który z miejsca stał się jednym z najbardziej rozpoznawalnych i najczęściej uwzględnianych w badaniach empirycznych wymiarów z obszaru psychologii różnic indywidualnych (por. Strelau, 2014). Podobnie jak inteligencja ogólna, również inteligencja emocjonalna nie doczekała się jednej, powszechnie akceptowanej definicji. Jednak większość badaczy zgodziłoby się prawdopodobnie, że pod tym terminem kryje się grupa zdolności umożliwiających rozpoznawanie emocji u siebie i innych ludzi, trafne ich nazywanie i rozumienie, regulację emocji, a także wykorzystywanie ich w kierowaniu własnym myśleniem i działaniem ${ }^{4}$ (por. Mayer, Salovey, Caruso, 2008). Tak rozumiane zdolności mogą okazać się przydatne w niemal każdej dziedzinie życia, włączając w to obszary nauki, pracy oraz bliskich związków (Śmieja, Orzechowski, 2008). Zważywszy na szczególnie emocjonalny charakter sytuacji rywalizacji sportowej (por. np. Laborde, Brüll, Weber, Anders, 2011), zasadnym wydaje się oczekiwanie istotnej roli inteligencji emocjonalnej w kontekście funkcjonowania jednostek w sporcie.

W literaturze przedmiotu znaleźć możemy co najmniej kilka prac, których autorzy podjęli próbę odpowiedzi na pytanie o znaczenie inteligencji emocjonalnej dla poziomu wykonania sportowego. W podłużnym badaniu, przeprowadzonym z udziałem 104 krykiecistów, grających na co dzień w reprezentacjach narodowych, wykazano, że średni poziom inteligencji emocjonalnej (mierzonej testem maksymalnego wykonania) w zespole był związany z obiektywnymi wynikami uzyskiwanymi przez drużynę (Crombie, Lombard, Noakes, 2009). Z kolei w badaniach korelacyjnych, przeprowadzonych na grupach koszykarzy (Zizzi, Deaner, Hirschhorn, 2003) i hokeistów (Perlini, Halverson, 2006), inteligencja emocjonalna (w tym wypadku mierzona metodami samoopisowymi) okazała się związana ze wskaźnikami wykonania zagregowanymi na przestrzeni całego sezonu rozgrywek. Analizy strukturalne przeprowadzone przez Laborde’a, Dosseville’a, Guilléna i Cháveza (2014) wskazują na to, iż mechanizmów pośredniczących pomiędzy poziomem zdolności emocjonalnych a wykonaniem sportowym należy szukać w skuteczniejszych mechanizmach radzenia sobie ze stresem - zawodnicy o wyższym poziomie inteligencji emocjonalnej częściej oceniają stresującą sytuację jako wyzwanie i używają bardziej adaptacyjnych strategii radzenia sobie w odpowiedzi na trudne i nieprzyjemne emocje doświadczane podczas zawodów. Nie bez znaczenia moga być w tym

4 Zdolności te stanowią część wspólną większości modeli inteligencji emocjonalnej. Jednocześnie liczni badacze na różne sposoby poszerzaja granice tego pojęcia, dodając doń takie charakterystyki jak asertywność, radzenie sobie ze stresem, samoświadomość czy empatia. 
wypadku również zmienne motywacyjne. Poziom inteligencji emocjonalnej okazał się wyraźnym predyktorem zdolności do motywowania samego siebie do odnoszenia sukcesów w sporcie (Kajbafenzhad, Ahadi, Heidarie, Askari, Enayati, 2012). W innym badaniu (Lane i in., 2009) sportowcy o wyższym poziomie inteligencji emocjonalnej częściej korzystali z adaptacyjnych technik samoregulacji w sporcie, takich jak: mowa wewnętrzna, strategie wyobrażeniowe, aktywna kontrola emocji, formułowanie celów, regulacja aktywacji czy techniki relaksacyjne.

Podsumowując powyższy, z konieczności pobieżny przegląd badań ${ }^{5}$, możemy stwierdzić, iż inteligencja „poznawcza” oraz inteligencja emocjonalna wpływają na odmienne aspekty funkcjonowania w sporcie. Podczas gdy pierwsza z nich zdaje się szczególnie ważna dla bieżącego przetwarzania informacji i procesów podejmowania decyzji podczas rywalizacji sportowej, druga pozwala jednostce stworzyć bardziej korzystne „zaplecze” afektywno-motywacyjne, niejako optymalizując jej stan emocjonalny. Jak już wspomnieliśmy powyżej, odpowiedni stan emocjonalny może wpływać na stopień, w jakim wykorzystujemy posiadane zasoby poznawcze (por. Humphreys, Revelle, 1984). Dlatego też wydaje się, iż interesującym kierunkiem dalszych badań w omawianym obszarze byłaby próba odpowiedzi na pytanie o interakcyjne efekty inteligencji emocjonalnej i zdolności poznawczych uznawanych za wskaźniki inteligencji płynnej (uwaga, pamięć robocza, funkcje wykonawcze). Zasadnym wydaje się bowiem przypuszczenie, iż dzięki efektywnej regulacji emocji i poziomu pobudzenia podczas wykonania sportowego, zawodnicy o wysokim poziomie inteligencji emocjonalnej moga efektywniej wykorzystywać posiadane zasoby poznawcze (por. Stolarski, 2009).

\section{CZY SPORT I AKTYWNOŚĆ FIZYCZNA MOGĄ WPŁYWAĆ NA POZIOM INTELI-}

GENCJI? Aby podjąć próbę odpowiedzi na powyższe pytanie, należy dokonać uporządkowania terminów stosowanych w psychologii sportu. Czym więc są i w jaki sposób odróżnić można aktywność fizyczna (physical activity) oraz wysiłek fizyczny (physical exercise) od uprawiania sportu (sport)? Aktywność fizyczna (physical activity) jest definiowana jako „dowolna forma ruchu ciała spowodowana skurczem mięśni, przy którym wydatek energii przekracza poziom energii spoczynkowej" (World Health Organization [WHO], 2010).

5 Czytelników zainteresowanych bardziej pogłębioną analizą roli inteligencji emocjonalnej w kontekście sportu odsyłamy do systematycznego przeglądu badań, który wykonali Laborde $\mathrm{i}$ in. (2016). 
Jest to jednak definicja zbyt szeroka, aby mogła być używana w niniejszym rozdziale. Czy w takim razie osoba siedząca przed komputerem i uderzająca palcami w klawiaturę podejmuje aktywność fizyczną? Wysiłek fizyczny (physical exercise) jest rozumiany jako: ,ustrukturyzowana, powtarzalna aktywność fizyczna, której celem jest poprawa lub utrzymanie szeroko pojętej kondycji organizmu" (WHO, 2010). Taka definicja jest już jak najbardziej odpowiednia dla naszych celów. Niestety, nie jest jednak tożsama z powszechnym rozumieniem sformułowania „wysiłek fizyczny”, w związku z tym w dalszej części artykułu będziemy zastępczo używać także wyrażenia „trening sportowy”.

Warto podkreślić, że tak jak nie każda aktywność fizyczna musi być sportem, tak uprawianiu sportu niekoniecznie musi towarzyszyć wysiłek fizyczny. Można tu wspomnieć o szachach czy grze w brydża, ale także o rosnącym na znaczeniu fenomenie, jakim jest e-sport, który według teorii sportu może bez przeszkód być uznawany za sport (Stępnik, 2009). Dlatego też dla klarowności zaznaczmy, że mówiąc o trenowaniu oraz sporcie, będziemy się odnosili do tych sportów, których uprawianie jest związane z wysiłkiem fizycznym.

\section{DLACZEGO AKTYWNOŚĆ SPORTOWA MOŻE WPŁYWAĆ NA POZIOM INTELIGEN-}

CJI? Według zaleceń WHO człowiek pomiędzy 18. a 64. rokiem życia powinien zażywać minimum 150 minut umiarkowanej aktywności fizycznej w ciagu tygodnia lub nie mniej niż 75 minut bardziej intensywnego treningu, dodatkowo suplementując swoją tygodniową „dietę aktywności fizycznej” co najmniej dwiema sesjami ćwiczeń wzmacniających mięśnie i kości. Jest to absolutne minimum, które dla lepszych efektów zdrowotnych powinno zostać podwojone (WHO, 2010). Celem tych zaleceń jest nie tylko próba przeciwdziałania skutkom siedzącego trybu życia (Vaynman, Gomez-Pinilla, 2006) i poprawa ogólnego stanu zdrowia, ze szczególnym uwzględnieniem przeciwdziałania otyłości i chorobom układu krążenia. W stanowisku WHO pojawia się też komponent związany z psychika - podejmowanie aktywności fizycznej dla przeciwdziałania rozwojowi depresji. Zdrowie emocjonalne to jednak nie jedyny obszar zainteresowania psychologów, który może ulegać pożądanym zmianom dzięki zwiększeniu poziomu aktywności fizycznej czy wprowadzeniu specyficznego (ze względu na typ, zadania czy intensywność) rodzaju treningu sportowego. Funkcje poznawcze, bo o nich mowa, stanowia procesualne podłoże dla różnic indywidualnych w zakresie inteligencji (Nęcka, 2005). Obecnie w literaturze dominują trzy nurty badań odpowiadające trzem hipotetycznym mechanizmom wpływu wysiłku fizycznego na funkcjonowanie poznawcze. Pierwszy z nich odwołuje się do zwiększonej neuroplastyczności, drugi do zmian w po- 
ziomie neuroprzekaźników, a trzeci do pośredniczącej roli wydajności układu krwionośnego (de Greeff, Bosker, Oosterlaan, Visscher, Hartman, 2018).

Wysiłek fizyczny może być postrzegany jako specyficzny czynnik środowiskowy, prowadzący do strukturalnych oraz funkcjonalnych zmian w mózgu (por. Mandolesi i in., 2018), stymulowania neurogenezy, opóźnienia neuronalnej apoptozy (w badaniach prowadzonych z udziałem zwierzat; Van Praag, Kempermann, Gage, 2000), a także skutkujący zwiększonym wydzielaniem neurotroficznego czynnika pochodzenia mózgowego (brain-derived neurotrophic factor, BDNF; Hötting, Schickert, Kaiser, Röder, Schmidt-Kassow, 2016) czy dopaminy (de Greeff $\mathrm{i}$ in., 2018), dodatkowo poprawiając też metabolizm energetyczny i przepływ krwi w mózgu (Mandolesi i in., 2017). Przeprowadzone badania dostarczają też dowodów na wpływ wysiłku fizycznego na zmniejszenie uszkodzeń i poprawę mikrostruktury istoty białej u dzieci (Chaddock-Heyman i in., 2014), zwiększenie objętości istoty szarej w okolicy czołowej i w hipokampie (Erickson i in., 2011; Tarkka i in., 2019), zwiększenie objętości istoty szarej i białej w korze skroniowej oraz w korze przedczołowej u osób starszych (Colcombe i in., 2006), jak i zwiększenie sumarycznej objętości całego mózgu ${ }^{6}$ (Hamer, Sharma, Batty, 2018) oraz lepszą integracją między jego modułami (Douw, Nieboer, van Dijk, Stam, Twisk, 2014). Dodatkowo szereg badań potwierdza też, że odpowiedni poziom aktywności fizycznej u osób starszych może być czynnikiem opóźniającym procesy neurodegeneracyjne, spowalniając starzenie się mózgu (Kerr i in., 2013), chroniąc przy tym, między innymi, przed wystapieniem choroby Parkinsona (Paillard, Rolland, de Souto Barreto, 2015), a także spowalniając tempo jej rozwoju (Fernández-del-Olmo i in., 2018). Podobne, ochronne właściwości wysiłku fizycznego znajdują swoje potwierdzenie w badaniach nad procesami neurodegeneracyjnymi prowadzacymi do rozwoju choroby Alzheimera (Phillips, Baktir, Das, Lin, Salehi, 2015). Wskazuje się też, że wysiłek fizyczny może wspomagać funkcjonowanie poznawcze poprzez osłabianie wpływu stresu na organizm (por. Dishman i in., 2006). Podsumowując, wśród naukowców panuje obecnie konsensus - wysiłek fizyczny korzystnie wpływa na funkcje poznawcze człowieka, a odpowiada za to kilka różnych mechanizmów związanych między innymi ze: zmianami strukturalnymi w mózgu, bardziej optymalnym ukrwieniem odpowiednich obszarów mózgu, korzystnymi zmianami w poziomie neuroprzekaźników czy ochrona przed zmianami neurodegeneracyjnymi (Mandolesi i in., 2018). Pochodzące z

6 Która, jak wiemy z innych badań, koreluje dodatnio z poziomem inteligencji (zob. McDaniel, 2005). 
badań dowody empiryczne ich wpływu na funkcjonowanie poznawcze zostaną dokładniej omówione w kolejnej części niniejszego rozdziału.

JAK AKTYWNOŚĆ SPORTOWA MOŻE WPŁYWAĆ NA POZIOM INTELIGENCJI? BIOrąc pod uwagę obecny stan wiedzy, nie jest możliwe wskazanie jednego obszaru mózgu, który byłby w całości odpowiedzialny za poziom inteligencji (por. Jung, Haier, 2007). Aby poprawnie ujmować neuronalne podłoże inteligencji, konieczne jest odwołanie się do różnych struktur mózgowych (Sporns, Bullmore, 2014), szczególnie ze względu na to, że pełnią one odmienne funkcje i odpowiadaja za różne mechanizmy, a, jak wspominaliśmy we wstępie, samo pojęcie „inteligencja” odnosi się do ogólnej sprawności poznawczej, ergo, musi zawierać w sobie wiele jakościowo odmiennych aspektów i funkcji. Dla przykładu: okolica czołowa odgrywa ważną rolę w procesach uwagowych i $\mathrm{w}$ funkcjonowaniu pamięci roboczej, jest też ważna z punktu widzenia funkcji wykonawczych, a różnice w objętości istoty szarej w okolicy czołowej są rzeczywiście istotnie powiązane z poziomem inteligencji (Thompson $\mathrm{i}$ in., 2001). Wymienione funkcje, przypisywane okolicy czołowej, nie wyczerpuja jednak definicji inteligencji, tym bardziej jeśli inteligencję ujmujemy jako grupę zdolności skrystalizowanych, przejawiających się w konkretnym kontekście. W odniesieniu do sportu nie obejmuja na przykład pamięci przestrzennej i orientacji w przestrzeni, czyli elementów niezbędnych do funkcjonowania w sporcie, których sprawność łączona jest z hipokampem (Bird, Burgess, 2008). Jak pokazują badania, obydwa te obszary - hipokamp i kora czołowa - moga zmieniać się pod wpływem aktywności fizycznej (Erickson i in., 2011; Tarkka i in., 2019). Przyjrzyjmy się więc konkretnym, opartym na mechanizmach opisanych w poprzedzającej części tego rozdziału, efektom uprawiania sportu.

Za punkt wyjścia przyjmijmy badania, w których porównuje się osoby aktywne fizycznie z osobami prowadzącymi tzw. „siedzący” tryb życia. Grupa osób aktywnych fizycznie osiaga w nich średnio wyższy poziom wykonania w zadaniach poznawczych, przodując także w dziedzinie osiagnięć akademickich, niezależnie od tego, w jakim wieku są uczestnicy badań (Churchill i in., 2002; Donnelly i in., 2016; Sibley, Etnier, 2003). Dodatkowo dzieci podejmujące więcej aktywności o charakterze tlenowym (aerobowym, który dla uproszczenia możemy skojarzyć z wysiłkiem o umiarkowanej intensywności) osiagaja też lepsze wyniki w testach werbalnych, percepcyjnych czy w zadaniach arytmetycznych (Sibley, Etnier, 2003; Voss i in., 2011). Osoby raportujące wyższy poziom aktywności fizycznej uzyskują wyższe wyniki w zadaniach mierzacych 
sprawność funkcji wykonawczych i procesów uwagowych czy zdolność zapamiętywania informacji (Kramer i in., 1999; Pereira i in., 2007; Winter i in., 2007).

Opisane powyżej badania prowadzone były głównie w podejściu przekrojowym (funkcje poznawcze oraz poziom aktywności fizycznej mierzono w tym samym momencie). Taki plan badawczy niesie za sobą szereg ograniczeń, przede wszystkim nie pozwalając na wnioskowanie przyczynowo-skutkowe. Dlatego też, choć obserwowane efekty mogą być skutkiem aktywności fizycznej, niewykluczony jest odwrotny kierunek tej zależności. Przykładowo osoby posiadające większą objętość istoty szarej w okolicy czołowej moga się charakteryzować pewnymi cechami, które sprzyjaja podejmowaniu częstszej i bardziej regularnej aktywności fizycznej (Hötting, Röder, 2013) - obszar ten związany jest wszakże z samokontrolą a ta ostatnia może sprzyjać większej sumienności, np. w realizacji postanowień treningowych. Zwróćmy więc uwagę na badania dające bardziej solidne podstawy do stawiania wniosków o kierunku zależności, a więc badania podłużne, a w kolejnej części także eksperymentalne.

Jak pokazaliśmy w poprzedniej części tego rozdziału, powiązania między uprawianiem sportu a poziomem inteligencji nie ograniczają się do różnic strukturalnych w budowie mózgu. Istotnym czynnikiem jest też wydolność układu krwionośnego, na który, co nie ulega wattpliwości, wpływ ma poziom aktywności fizycznej (Åberg i in., 2009; Hillman, Erickson, Kramer, 2008). W interesującym projekcie Åberg i in. (2009) badali mężczyzn werbowanych do służby wojskowej, urodzonych w Szwecji w latach 1950-1976. Uzyskane przez nich wyniki wskazują na istotne powiązania między wydolnością układu krwionośnego a poziomem inteligencji, a przy tym także na brak związku między siła mięśni a poziomem inteligencji. Co ciekawe, mając możliwość analizy porównawczej par braci, w tym bliźniąt jedno- i dwujajowych, badacze zwrócili uwagę na rolę środowiska specyficznego jako najważniejszego czynnika odpowiadającego za współzmienność stanu układu krwionośnego $\mathrm{i}$ inteligencji. Innymi słowy, sposób, w jaki badani spędzali czas, miał dużo większe znaczenie dla wydolności układu krwionośnego niż czynniki genetyczne. Wydolność układu sercowo-naczyniowego była też istotnym predyktorem statusu socjoekonomicznego i osiagnięć akademickich. Warto jednak zwrócić uwagę na pewne ograniczenia badania - uczestnicy byli grupą składającą się w całości z mężczyzn, a w drugim pomiarze nie sprawdzano poziomu inteligencji ani wydolności układu krwionośnego. Niemożliwe jest zatem wnioskowanie o bezpośrednich efektach przyczynowo-skutkowych. Wspomniany brak związku między siłą mięśni a poziomem inteligencji pozwala jednak zakładać, że hipo- 
teza, według której osoby o wyższym poziomie inteligencji uprawiają więcej sportu, jest mniej prawdopodobna niż hipoteza odwrotna.

Interesujące dopełnienie powyższych obserwacji można znaleźć w badaniach Hötting i Röder (2013), których wyniki pokazuja, że aktywność fizyczna we wcześniejszych fazach życia jest czynnikiem chroniącym przed obniżeniem możliwości poznawczych w późniejszych etapach życia, a także ograniczajacym ryzyko wystąpienia demencji. Dodatkowo warto zwrócić uwagę na wyniki metaanalizy, którą w 2018 roku przeprowadzili de Greeff i in. W świetle jej wyników interwencje zwiększające poziom aktywności ruchowej u dzieci przed okresem dojrzewania (6-12 lat) skutkują poprawą zdolności uwagowych, a także funkcji wykonawczych (w tym elastyczności poznawczej, pamięci roboczej, hamowania reakcji i planowania), przy czym efekt poprawy w przypadku uwagi jest znacznie większy niż w przypadku funkcji wykonawczych.

$\mathrm{Na}$ koniec przejdziemy do badań prowadzonych w schemacie eksperymentalnym oraz interwencyjnym. Składaja się na nie dwa rodzaje podejść metodologicznych. W pierwszym z nich badane są długofalowe efekty treningu lub kontrolowanej aktywności fizycznej podejmowanej przez dłuższy czas (np. trzy tygodnie lub sześć miesięcy). Dane z metaanalizy, w której analizowano wyłącznie badania eksperymentalne, potwierdzają istotność wpływu wysiłku o charakterze tlenowym na poprawę funkcjonowania poznawczego, w tym lepszą orientację w przestrzeni i uwagę, zarówno w odniesieniu do bodźców o charakterze wizualnym, jak i słuchowym, a także większą szybkość przetwarzania bodźców czy kontrolę ruchową (Angevaren, Aufdemkampe, Verhaar, Aleman, Vanhees, 2008). Trening sportowy może też nieznacznie poprawiać czas reakcji, ale tylko u młodych osób (Hansen, Johnsen, Sollers, Stenvik, Thayer, 2004). Interesujące wyniki raportują też Hötting i in. (2012), zainteresowani wpływem wysiłku fizycznego na pamięć. W badaniu z udziałem osób w średnim wieku, prowadzących siedzący tryb życia, dokonali podziału na trzy grupy: grupę odbywająca trening wytrzymałościowy na rowerze stacjonarnym, grupę biorącą udział w treningu koordynacyjno-rozciagającym oraz grupę kontrolną. Obie grupy ćwiczące odbywały trening dwa razy w tygodniu przez sześć miesięcy. W obu grupach podejmujących dodatkowy trening sportowy zaobserwowano poprawę pamięci epizodycznej, związaną też z polepszeniem wydolności układu krwionośnego. U osób, które w większym stopniu poprawiły swoją wydolność sercowo-naczyniową, odnotowano także większą poprawę pamięci. Podobne wyniki raportują Stroth, Hille, Spitzer, Reinhardt (2009): w grupie młodych dorosłych sześć tygodni treningu wydolnościowego o charakterze tlenowym, trwającego 30 minut i podejmowanego trzy razy w ty- 
godniu prowadziło do poprawy w zakresie krótkotrwałej pamięci przestrzenno-wizualnej, w porównaniu z grupa, która nie podejmowała dodatkowego, zorganizowanego treningu? .

Podobnie jak w przypadku innych funkcji poznawczych zwiększenie objętości i częstotliwości podejmowania wysiłku tlenowego może przeciwdziałać efektom starzenia się mózgu i powodować także polepszenie pamięci. Wniosek ten częściowo potwierdza poprawa w funkcjonowaniu pamięci werbalnej u osób po 50. roku życia, podejmujących dodatkowy wysiłek fizyczny, w porównaniu z grupa prowadzącą bardziej siedzący tryb życia (Ruscheweyh i in., 2011). Z drugiej strony, w tym samym badaniu nie zaobserwowano różnic między grupa podejmującą wysiłek tlenowy a tą uczestniczącą w zajęciach gimnastycznych. W innych badaniach udało się zaobserwować zmiany strukturalne w mózgu, będące efektem podejmowania dodatkowego wysiłku fizycznego, ale zmiany te zdają się nie przekładać na oczekiwane różnice w funkcjonowaniu pamięci roboczej (Erickson i in., 2011).

Trzeba jednak wspomnieć, że badania nad długofalowymi efektami wysiłku fizycznego również mają pewne ograniczenia i trudności metodologiczne. Wynikaja one głównie z tego, że zazwyczaj porównuje się grupę, która brała udział w interwencji (tj. podejmowała pewien rodzaj wysiłku fizycznego o ściśle określonej formie i intensywności), z druga grupa, która nie podlegała interwencji, pełniąc rolę grupy kontrolnej. Niestety w wielu badaniach grupa kontrolna podejmuje inną aktywność fizyczną, która, paradoksalnie, może prowadzić do podobnych efektów w odniesieniu do funkcji poznawczych, co z kolei uniemożliwia zauważenie istotnych statystycznie różnic między grupami (Hötting, Röder, 2013). Warto też zwrócić uwagę, że w takim schemacie badawczym wysiłek fizyczny nie jest jedyną różnicą pomiędzy badanymi grupami - trzeba przecież wziąć pod uwagę stymulację płynąca z nowych kontaktów społecznych, które to również wpływają wspierająco na neuroplastyczność (Van Praag i in., 2000), czy też efekt przebywania w nowym miejscu - szczególnie jeśli zajęcia sportowe odbywają się na zewnątrz (Burgess, Maguire, O'Keefe, 2002).

W drugim podejściu do badań eksperymentalnych obiektem zainteresowań naukowców jest wpływ pojedynczej sesji treningowej na funkcjonowanie poznawcze osób badanych. Wpływ ten mierzony jest zaraz po zakończeniu

7 Warto zaznaczyć, że grupa trenująca raportowała wyższy poziom pozytywnego afektu, który jest dodatnio związany z zachowaniami kreatywnymi (Isen, Daubman, Nowicki, 1987), a te wliczają się do przedstawionej na początku tego rozdziału kategorii sportowej inteligencji, zdefiniowanej przez Goulda i in. (2002). 
sesji. Jak w swoim artykule przeglądowym zauważają Basso i Suzuki (2017), poszczególne badania prowadzone w takim schemacie są często trudne do porównania - wynika to z ich silnego zróżnicowania pod względem wybranej formy wysiłku fizycznego, jego intensywności i czasu trwania, jak również pod względem testów wykorzystywanych do mierzenia sprawności funkcji poznawczych oraz tego, po jakim czasie od wysiłku dokonywany jest pomiar funkcji poznawczych. Interesującym przykładem mogą tu być badania nad wpływem jednorazowego wysiłku fizycznego na funkcjonowanie pamięci epizodycznej. Pozytywny wpływ, jaki może przynieść jedna sesja treningowa, jest bardzo dobrze udokumentowany. Jednak dokładniejsza analiza pokazuje, że istnieje szereg moderatorów, czyli zmiennych, które mogą modyfikować sposób, w jaki wysiłek fizyczny wpływa na pamięć epizodyczną. Są to, między innymi: wiek osób badanych, rodzaj wysiłku, jak i umiejscowienie tegoż wysiłku w czasie: przed faza kodowania (encoding), w jej trakcie, czy w fazie konsolidacji. Wspierający dla funkcjonowania pamięci epizodycznej jest wysiłek mający miejsce w fazie konsolidacji śladów pamięciowych, natomiast ten odbywający się w fazie kodowania może mieć odwrotny efekt. Dokładniejsza analiza pozwala jednak zauważyć tu jeszcze jedną zmienną moderująca - wiek osób badanych - kontrproduktywny efekt wysiłku fizycznego w fazie kodowania jest ograniczony tylko do grupy osób starszych. Dodatkowo okazuje się, że jazda na rowerze może wspomagać funkcjonowanie pamięci epizodycznej bardziej efektywnie niż chód lub bieg o podobnej intensywności (por. Loprinzi i in., 2019). Zdarzaja się też badania, w których prowadzone ćwiczenia są na tyle wymagające, że skutkują nawet odwodnieniem u osób badanych. Nie jest więc zaskakującym fakt, że w takich badaniach nie wykazano pozytywnego wpływu ćwiczeń na funkcje poznawcze (Lambourne, Tomporowski, 2010). Biorąc to pod uwage, w tej części przedstawimy dowody i wnioski pochodzące tylko i wyłącznie z metaanaliz i artykułów przeglądowych, wskazując powyżej wspomniany artykuł przeglądowy jako wyczerpujące źródło bardziej szczegółowych informacji (Basso, Suzuki, 2017).

Analogicznie jak w przypadku długotrwałego uprawiania sportu jednorazowy wysiłek fizyczny prowadzi do poprawy wykonania w zadaniach poznawczych, usprawniając funkcjonowanie uwagi, pamięci roboczej, a także planowania działań, wnioskowania, podejmowania decyzji, elastyczności poznawczej, płynności werbalnej, a także szybkości przetwarzania bodźców i hamowania reakcji (Basso, Shang, Elman, Karmouta, Suzuki, 2015). Badania pokazują też pozytywny, ale nieco mniej znaczący niż w wypadku powyższych zmiennych, wpływ jednej sesji ćwiczeń na pamięć długotrwałą i uczenie się, sprawność 
pamięci asocjacyjnej, a także umiejętności bazujące na funkcjonowaniu pierwotnej kory wzrokowej i ruchowej. Wymienionym zmianom towarzyszy też zmniejszenie poziomu stresu, które może dodatkowo poprawiać funkcjonowanie poznawcze, a zmiany będące efektem takiego treningu utrzymują się do około dwóch godzin po zakończeniu ćwiczeń (Basso i in., 2015).

\section{PODSUMOWANIE}

Opisane powyżej mechanizmy, jak i efekty wpływu, tak jednorazowego, jak i długotrwałego, w klarowny sposób pokazują szereg korzyści, które wysiłek fizyczny może przynieść dla funkcjonowania poznawczego. I choć sprawność poszczególnych funkcji poznawczych jest zazwyczaj sprawdzana w warunkach laboratoryjnych, przy użyciu różnych, mniej lub bardziej skomplikowanych testów - wyniki uzyskiwane w tychże testach zawierają w sobie dużą wartość prognostyczną i mogą być generalizowane na funkcjonowanie jednostek w rzeczywistym świecie (Basso i in., 2015). Patrząc z tej perspektywy, wymienione wcześniej wytyczne WHO dotyczące minimum aktywności fizycznej, którą dla zachowania zdrowia powinien zażywać człowiek, zyskują nową wymowę - sa bowiem rozszerzone o element funkcjonowania poznawczego. Wyznaczaja także drogę do utrzymania lub nawet poprawy nie tylko kondycji fizycznej, ale także wykorzystywania pełni swojego potencjału umysłowego. Potencjału umysłowego, który w profesjonalnym sporcie bywa definiowany jako sportowa inteligencja (Gould i in., 2002) i stanowi jeden z najważniejszych predyktorów poziomu wykonania sportowego.

\section{BIBLIOGRAFIA}

Åberg, M. A., Pedersen, N. L., Torén, K., Svartengren, M., Bäckstrand, B., Johnsson, T., ..., Kuhn, H. G. (2009). Cardiovascular fitness is associated with cognition in young adulthood. Proceedings of the National Academy of Sciences, 106(49), 20906-20911. https://doi.org/10.1073/pnas.0905307106

Abernethy, B. (1991). Visual search strategies and decision making in sport. International Journal of Sport Psychology, 22(3-4), 189-210.

Abernethy, B., Russell, D. G. (1984). Advance cue utilisation by skilled cricket batsmen. Australian Journal of Science and Medicine in Sport, 16(2), 2-10.

Angevaren, M., Aufdemkampe, G., Verhaar, H. J. J., Aleman, A., Vanhees, L. (2008). Physical activity and enhanced fitness to improve cognitive function in older peo- 
ple without known cognitive impairment. Cochrane Database of Systematic Reviews, 2, CD005381. https://doi.org/10.1002/14651858.CD005381.pub2

Basso, J. C., Suzuki, W. A. (2017). The effects of acute exercise on mood, cognition, neurophysiology, and neurochemical pathways: A review. Brain Plasticity, 2(2), 127-152. https://doi.org/10.3233/BPL-160040

Basso, J. C., Shang, A., Elman, M., Karmouta, R., Suzuki, W. A. (2015). Acute exercise improves prefrontal cortex but not hippocampal function in healthy adults. Journal of the International Neuropsychological Society, 21(10), 791-801. https://doi. org/10.1017/S135561771500106X

Bird, C. M., Burgess, N. (2008). The hippocampus and memory: Insights from spatial processing. Nature Reviews Neuroscience, 9(3), 182-194. https://doi.org/10.1038/ nrn2335

Burgess, N., Maguire, E. A., O’Keefe, J. (2002). The human hippocampus and spatial and episodic memory. Neuron, 35(4), 625-641. https://doi.org/10.1016/S08966273(02)00830-9

Cattell, R. B. (1963). Theory of fluid and crystallized intelligence: A critical experiment. Journal of Educational Psychology, 54(1), 1-22. https://doi.org/10.1037/ h0046743

Chaddock-Heyman, L., Erickson, K. I., Holtrop, J. L., Voss, M. W., Pontifex, M. B., Raine, L. B., ..., Kramer, A. F. (2014). Aerobic fitness is associated with greater white matter integrity in children. Frontiers in Human Neuroscience, 8, 584. https:// doi.org/10.3389/fnhum.2014.00584

Churchill, J. D., Galvez, R., Colcombe, S., Swain, R. A., Kramer, A. F., Greenough, W. T. (2002). Exercise, experience and the aging brain. Neurobiology of Aging, 23(5), 941-955. https://doi.org/10.1016/S0197-4580(02)00028-3

Colcombe, S. J., Erickson, K. I., Scalf, P. E., Kim, J. S., Prakash, R., McAuley, E., ..., Kramer, A. F. (2006). Aerobic exercise training increases brain volume in aging humans. The Journals of Gerontology Series A: Biological Sciences and Medical Sciences, 61(11), 1166-1170. https://doi.org/10.1093/gerona/61.11.1166

Crombie, D., Lombard, C., Noakes, T. (2009). Emotional intelligence scores predict team sports performance in a national cricket competition. International Journal of Sports Science \& Coaching, 4(2), 209-224. https://doi. org/10.1260/174795409788549544

de Greeff, J. W., Bosker, R. J., Oosterlaan, J., Visscher, C., Hartman, E. (2018). Effects of physical activity on executive functions, attention and academic performance in preadolescent children: A meta-analysis. Journal of Science and Medicine in Sport, 21(5), 501-507. https://doi.org/10.1016/j.jsams.2017.09.595 
Dishman, R. K., Berthoud, H. R., Booth, F. W., Cotman, C. W., Edgerton, V. R., Fleshner, M. R., ..., Kramer, A. F. (2006). Neurobiology of exercise. Obesity, 14(3), 345-356. https://doi.org/10.1038/oby.2006.46

Donnelly, J. E., Hillman, C. H., Castelli, D., Etnier, J. L., Lee, S., Tomporowski, P., ..., Szabo-Reed, A. N. (2016). Physical activity, fitness, cognitive function, and academic achievement in children: A systematic review. Medicine and Science in Sports and exercise, 48(6), 1197-1222. https://doi.org/10.1249/MSS.0000000000000901

Douw, L., Nieboer, D., van Dijk, B. W., Stam, C. J., Twisk, J. W. (2014). A healthy brain in a healthy body: Brain network correlates of physical and mental fitness. PLoS One, 9, e88202. https://doi.org/10.1371/journal.pone.0088202

Erickson, K. I., Voss, M. W., Prakash, R. S., Basak, C., Szabo, A., Chaddock, L., ..., Wojcicki, T. R. (2011). Exercise training increases size of hippocampus and improves memory. Proceedings of the National Academy of Sciences, 108(7), 3017-3022. https://doi.org/10.1073/pnas.1015950108

Fernández-del-Olmo, M., Molina, J. A. S., Morenilla-Burló, L., Varela, J. G., Lago, H. F., Bello, O., García, D. S. (2018). Aerobic and resistance exercises in Parkinson's disease: A narrative review. European Journal of Human Movement, 41, 149-174.

Gardner, H. (1983). Frames of mind: The theory of multiple intelligences. Nowy Jork: Basic Books.

Gould, D., Dieffenbach, K., Moffett, A. (2002). Psychological characteristics and their development in Olympic champions. Journal of Applied Sport Psychology, 14(3), 172-204. https://doi.org/10.1080/10413200290103482

Hamer, M., Sharma, N., Batty, G. D. (2018). Association of objectively measured physical activity with brain structure: UK Biobank study. Journal of Internal Medicine, 284(4), 439-443. https://doi.org/10.1111/joim.12772

Hansen, A. L., Johnsen, B. H., Sollers, J. J., Stenvik, K., Thayer, J. F. (2004). Heart rate variability and its relation to prefrontal cognitive function: the effects of training and detraining. European Journal of Applied Physiology, 93(3), 263-272. https://doi.org/10.1007/s00421-004-1208-0

Hillman, C. H., Erickson, K. I., Kramer, A. F. (2008). Be smart, exercise your heart: Exercise effects on brain and cognition. Nature Reviews Neuroscience, 9(1), 58-65. https://doi.org/10.1038/nrn2298

Hötting, K., Reich, B., Holzschneider, K., Kauschke, K., Schmidt, T., Reer, R., ..., Röder, B. (2012). Differential cognitive effects of cycling versus stretching/coordination training in middle-aged adults. Health Psychology, 31(2), 145-155. https:// doi.org/10.1037/a0025371 
Hötting, K., Röder, B. (2013). Beneficial effects of physical exercise on neuroplasticity and cognition. Neuroscience \& Biobehavioral Reviews, 37(9), 2243-2257. https://doi. org/10.1016/j.neubiorev.2013.04.005

Hötting, K., Schickert, N., Kaiser, J., Röder, B., Schmidt-Kassow, M. (2016). The effects of acute physical exercise on memory, peripheral BDNF, and cortisol in young adults. Neural Plasticity, 2016,1-12. https://doi.org/10.1155/2016/6860573

Huijgen, B. C., Leemhuis, S., Kok, N. M., Verburgh, L., Oosterlaan, J., Elferink-Gemser, M. T., Visscher, C. (2015). Cognitive functions in elite and sub-elite youth soccer players aged 13 to 17 years. PLoS One, 10(12), e0144580. https://doi. org/10.1371/journal.pone.0144580

Humphreys, M. S., Revelle, W. (1984). Personality, motivation, and performance: A theory of the relationship between individual differences and information processing. Psychological Review, 91(2), 153-184. https://doi.org/10.1037/0033295X.91.2.153

Isen, A. M., Daubman, K. A., Nowicki, G. P. (1987). Positive affect facilitates creative problem solving. Journal of Personality and Social Psychology, 52(6), 1122-1131. https://doi.org/10.1037/0022-3514.52.6.1122

Jones, M. V. (2003). Controlling emotions in sport. The Sport Psychologist, 17(4), 471486. https://doi.org/10.1123/tsp.17.4.471

Jung, R. E., Haier, R. J. (2007). The Parieto-Frontal Integration Theory (P-FIT) of intelligence: Converging neuroimaging evidence. Behavioral and Brain Sciences, 30(2), 135-187. https://doi.org/10.1017/S0140525X07001185

Kajbafnezhad, H., Ahadi, H., Heidarie, A., Askari, P., Enayati, M. (2012). Predicting athletic success motivation using mental skills and emotional intelligence and its components in male athletes. The Journal of Sports Medicine and Physical Fitness, 52(5), $551-557$.

Kerr, J., Marshall, S. J., Patterson, R. E., Marinac, C. R., Natarajan, L., Rosenberg, D., ..., Crist, K. (2013). Objectively measured physical activity is related to cognitive function in older adults. Journal of the American Geriatrics Society, 61(11), 1927-1931. https:// doi.org/10.1111/jgs.12524

Kramer, A. F., Hahn, S., Cohen, N. J., Banich, M. T., McAuley, E., Harrison, C. R., ..., Colcombe, A. (1999). Ageing, fitness and neurocognitive function. Nature, 400, 418-419. https://doi.org/10.1038/22682

Laborde, S., Brüll, A., Weber, J., Anders, L. S. (2011). Trait emotional intelligence in sports: A protective role against stress through heart rate variability? Personality and Individual Differences, 51(1), 23-27. https://doi.org/10.1016/j.paid.2011.03.003 
Laborde, S., Dosseville, F., Allen, M. S. (2016). Emotional intelligence in sport and exercise: A systematic review. Scandinavian Journal of Medicine \& Science in Sports, 26(8), 862-874. https://doi.org/10.1111/sms.12510

Laborde, S., Dosseville, F., Guillén, F., Chávez, E. (2014). Validity of the trait emotional intelligence questionnaire in sports and its links with performance satisfaction. Psychology of Sport and Exercise, 15(5), 481-490. https://doi.org/10.1016/j. psychsport.2014.05.001

Lambourne, K., Tomporowski, P. (2010). The effect of exercise-induced arousal on cognitive task performance: A meta-regression analysis. Brain Research, 1341, 12-24. https://doi.org/10.1016/j.brainres.2010.03.091

Lane, A. M., Meyer, B. B., Devonport, T. J., Davies, K. A., Thelwell, R., Gill, G. S., ..., Weston, N. (2009). Validity of the emotional intelligence scale for use in sport. Journal of Sports Science \& Medicine, 8(2), 289-295.

Loprinzi, P. D., Blough, J., Crawford, L., Ryu, S., Zou, L., Li, H. (2019). The temporal effects of acute exercise on episodic memory function: Systematic review with meta-analysis. Brain Sciences, 9(4), 87-109. https://doi.org/10.3390/brainsci9040087

Mandolesi, L., Gelfo, F., Serra, L., Montuori, S., Polverino, A., Curcio, G., Sorrentino, G. (2017). Environmental factors promoting neural plasticity: Insights from animal and human studies. Neural Plasticity, 2017, 7219461. https://doi. org/10.1155/2017/7219461

Mandolesi, L., Polverino, A., Montuori, S., Foti, F., Ferraioli, G., Sorrentino, P., Sorrentino, G. (2018). Effects of physical exercise on cognitive functioning and wellbeing: Biological and psychological benefits. Frontiers in Psychology, 9, 509. https:// doi.org/10.3389/fpsyg.2018.00509

Mayer, J. D., Salovey, P., Caruso, D. R. (2008). Emotional intelligence: New ability or eclectic traits? American Psychologist, 63(6), 503-517. https://doi.org/10.1037/0003066X.63.6.503

McDaniel, M. A. (2005). Big-brained people are smarter: A meta-analysis of the relationship between in vivo brain volume and intelligence. Intelligence, 33(4), 337-346. https://doi.org/10.1016/j.intell.2004.11.005

McLeod, P. (1987). Visual reaction time and high-speed ball-games. Perception, 16(1), 49-59. https://doi.org/10.1068/p160049

McLeod, P., Jenkins, S. (1991). Timing accuracy and decision time in high speed ball games. International Journal of Sport Psychology, 22(3-4), 279-295.

Memmert, D. (2009). Pay attention! A review of visual attentional expertise in sport. International Review of Sport and Exercise Psychology, 2(2), 119-138. https://doi.org/10.1080/17509840802641372 
Nęcka, E. (2005). Inteligencja: Geneza, struktura, funkcje. Gdańsk: Gdańskie Wydawnictwo Psychologiczne.

Paillard, T., Rolland, Y., de Souto Barreto, P. (2015). Protective effects of physical exercise in Alzheimer's disease and Parkinson's disease: A narrative review. Journal of Clinical Neurology, 11(3), 212-219. https://doi.org/10.3988/jcn.2015.11.3.212

Pereira, A. C., Huddleston, D. E., Brickman, A. M., Sosunov, A. A., Hen, R., McKhann, G. M., ..., Small, S. A. (2007). An in vivo correlate of exercise-induced neurogenesis in the adult dentate gyrus. Proceedings of the National Academy of Sciences, 104(13), 5638-5643. https://doi.org/10.1073/pnas.0611721104

Perlini, A. H., Halverson, T. R. (2006). Emotional intelligence in the National Hockey League. Canadian Journal of Behavioural Science / Revue Canadienne des Sciences du Comportement, 38(2), 109-119. https://doi.org/10.1037/cjbs2006001

Phillips, C., Baktir, M. A., Das, D., Lin, B., Salehi, A. (2015). The link between physical activity and cognitive dysfunction in Alzheimer disease. Physical Therapy, 95, 1046-1060. https://doi.org/10.2522/ptj.20140212

Policastro, F., Accardo, A., Marcovich, R., Pelamatti, G., Zoia, S. (2018). Relation between motor and cognitive skills in Italian basketball players aged between 7 and 10 years old. Sports, 6(3), 80-87. https://doi.org/10.3390/sports6030080

Roca, A., Ford, P. R., Memmert, D. (2018). Creative decision making and visual search behavior in skilled soccer players. PLoS One, 13(7), e0199381. https://doi. org/10.1371/journal.pone.0199381

Ruscheweyh, R., Willemer, C., Krüger, K., Duning, T., Warnecke, T., Sommer, J., ..., Flöel, A. (2011). Physical activity and memory functions: An interventional study. Neurobiology of Aging, 32(7), 1304-1319. https://doi.org/10.1016/j.neurobiolaging.2009.08.001

Salovey, P., Mayer, J. D. (1990). Emotional intelligence. Imagination, Cognition and Personality, 9(3), 185-211.

Sheppard, L. D., Vernon, P. A. (2008). Intelligence and speed of information-processing: A review of 50 years of research. Personality and Individual Differences, 44(3), 535-551. https:// doi.org/10.1016/j.paid.2007.09.015

Sibley, B. A., Etnier, J. L. (2003). The relationship between physical activity and cognition in children: A meta-analysis. Pediatric Exercise Science, 15(3), 243-256. https:// doi.org/10.1123/pes.15.3.243

Sporns, O., Bullmore, E. T. (2014). From connections to function: The mouse brain connectome atlas. Cell, 157(4), 773-775. https://doi.org/10.1016/j.cell.2014.04.023

Stępnik, A. (2009). E-sport z perspektywy teorii sportu. Homo Ludens, 1(1), 213-222. Stolarski, M. (2009). Inteligencja emocjonalna a procesy uwagi: poznawcze implikacje emocjonalnej kompetencji. W: M. Ledzińska, M. Zajenkowski (red.), Z badań 
nad pograniczem intelektu i osobowości (s. 73-93). Warszawa: Wydawnictwo Instytutu Psychologii PAN.

Strelau, J. (2014). Różnice indywidualne. Historia, determinanty, zastosowania. Warszawa: Scholar.

Stroth, S., Hille, K., Spitzer, M., Reinhardt, R. (2009). Aerobic endurance exercise benefits memory and affect in young adults. Neuropsychological Rebabilitation, 19(2), 223-243. https://doi.org/10.1080/09602010802091183

Śmieja, M., Orzechowski, J. (2008). Inteligencja emocjonalna: Fakty, mity, kontrowersje. W: M. Śmieja, J. Orzechowski (red.), Inteligencja emocjonalna: Fakty, mity, kontrowersje (s. 19-45). Warszawa: Wydawnictwo Naukowe PWN.

Tarkka, I. M., Hautasaari, P., Pesonen, H., Niskanen, E., Rottensteiner, M., Kaprio, J., ..., Kujala, U. M. (2019). Long-term physical activity may modify brain structure and function: Studies in young healthy twins. Journal of Physical Activity and Health, 16(8), 637-643. https://doi.org/10.1123/jpah.2018-0416

Tenenbaum, G., Bar-Eli, M. (1995). Personality and intellectual capacities in sport psychology. W: D. H. Saklofske, M. Zeidner (red.), International handbook of personality and intelligence (s. 687-710). Nowy Jork: Plenum Press.

Thompson, P. M., Cannon, T. D., Narr, K. L., Van Erp, T., Poutanen, V. P., Huttunen, M., ..., Dail, R. (2001). Genetic influences on brain structure. Nature Neuroscience, 4(12), 1253-1258. https://doi.org/10.1038/nn758

Van Praag, H., Kempermann, G., Gage, F. H. (2000). Neural consequences of environmental enrichment. Nature Reviews Neuroscience, 1(3), 191-198. https://doi. org/10.1038/35044558

Vaynman, S., Gomez-Pinilla, F. (2006). Revenge of the „sit”: How lifestyle impacts neuronal and cognitive health through molecular systems that interface energy metabolism with neuronal plasticity. Journal of Neuroscience Research, 84(4), 699-715. https:// doi.org/10.1002/jnr.20979

Verburgh, L., Scherder, E. J., van Lange, P. A., Oosterlaan, J. (2014). Executive functioning in highly talented soccer players. PLoS One, 9(3), e91254. https://doi. org/10.1371/journal.pone.0091254

Vestberg, T., Reinebo, G., Maurex, L., Ingvar, M., Petrovic, P. (2017). Core executive functions are associated with success in young elite soccer players. PLoS One, 12(2), e0170845. https://doi.org/10.1371/journal.pone.0170845

Voss, M. W., Chaddock, L., Kim, J. S., VanPatter, M., Pontifex, M. B., Raine, L. B., ..., Kramer, A. F. (2011). Aerobic fitness is associated with greater efficiency of the network underlying cognitive control in preadolescent children. Neuroscience, 199, 166-176. https://doi.org/10.1016/j.neuroscience.2011.10.009 
Wagner, H., Finkenzeller, T., Würth, S., von Duvillard, S. P. (2014). Individual and team performance in team-handball: A review. Journal of Sports Science \& Medicine, 13(4), 808-816.

Wagstaff, C. R. (2014). Emotion regulation and sport performance. Journal of Sport and Exercise Psychology, 36(4), 401-412. https://doi.org/10.1123/jsep.2013-0257

Williams, A. M., Ford, P. R., Eccles, D. W., Ward, P. (2011). Perceptual-cognitive expertise in sport and its acquisition: Implications for applied cognitive psychology. Applied Cognitive Psychology, 25(3), 432-442. https://doi.org/10.1002/acp.1710

Winter, B., Breitenstein, C., Mooren, F. C., Voelker, K., Fobker, M., Lechtermann, A., ..., Knecht, S. (2007). High impact running improves learning. Neurobiology of Learning and Memory, 87(4), 597-609. https://doi.org/10.1016/j.nlm.2006.11.003

World Health Organization. (2010). Global recommendations on physical activity for health. Genewa: WHO Press.

Zizzi, S., Deaner, H., Hirschhorn, D. (2003). The relationship between emotional intelligence and performance among college basketball players. Journal of Applied Sport Psychology, 15(3), 262-269. https://doi.org/10.1080/10413200305390 

Sprawność intelektualna osób o odmiennych chronotypach $^{8}$

Konrad S. Jankowski iD https://orcid.org/0000-0003-0613-9532

Uniwersytet Warszawski, Wydział Psychologii

konrad.jankowski@psych.uw.edu.pl

8 Praca została przygotowana w ramach projektu Ministerstwa Nauki i Szkolnictwa Wyższego (IP2015026774).

SPOSÓB CYTOWANIA: Jankowski, K. S. (2021). Sprawność intelektualna osób o odmiennych chronotypach. W: M. Zajenkowski (red.), Inteligencja w codziennym życiu (s. 259-273). Warszawa: Wydawnictwo Liberi Libri. https://doi.org/10.47943/lib.9788363487515.rozdzial10 


\section{CHRONOTYP}

Pomimo tego, że inteligencja tradycyjnie rozpatrywana jest jako względnie stały potencjał osobniczy do wykonywania złożonych zadań poznawczych, to wykorzystanie tego potencjału zależeć może od różnych czynników, również o charakterze sytuacyjnym. Jednym $z$ takich czynników może być pora dnia podejmowania wysiłku intelektualnego, która z kolei związana jest z chronotypem jednostki. W niniejszym rozdziale podjęto zagadnienie relacji między inteligencją $i$ chronotypem.

Chronotyp, zwany też wymiarem ranności-wieczorności, jest charakterystyką podmiotowa zaliczana do cech temperamentu, opisującą to, kiedy podczas doby osoba jest aktywna. U osób o chronotypach porannych sen i czuwanie przypada na wcześniejsze godziny w porównaniu do osób o chronotypach wieczornych (Jankowski, 2008). Należy pamiętać, że chronotyp stanowi kontinuum, a kategoryzowanie służy ułatwieniu komunikacji wyników badań. Różnice indywidualne w zakresie chronotypu dotyczą nie tylko ludzi, ale również zwierząt (Lehmann i in., 2012). Czynniki genetyczne wyjaśniają około 50\% zmienności w zakresie chronotypu (Koskenvuo, Hublin, Partinen, Heikkilä, Kaprio, 2007) i związane są z różnicami w obszarze tak zwanych genów zegarowych (clock genes; Jankowski, Dmitrzak-Weglarz, 2017; Pedrazzoli i in., 2010). Innymi czynnikami biologicznymi związanymi z chronotypem są wiek i płeć. O ile dzieci są bardziej poranne, to w okresie adolescencji rozpoczyna się gwałtowne przesunięcie w stronę wieczorności, która osiaga szczyt w okolicach 20. roku życia, po czym wraz z wiekiem następuje przesunięcie w stronę poranności (Roenneberg $\mathrm{i}$ in., 2004). Od początku adolescencji do wieku okołomenopauzalnego, u mężczyzn sen przypada na późniejsze godziny niż u kobiet, co wraz z opisanymi powyżej zmianami rozwojowymi dało przypuszczenie, że na chronotyp mogą mieć wpływ hormony płciowe. W istocie, u mężczyzn wyższy poziom testosteronu powiązany jest z chronotypem wieczornym (Jankowski, Fajkowska, Domaradzka, Wytykowska, 2019).

Okres rytmu generowanego przez zegar biologiczny u większości ludzi wynosi nieco ponad 24 godziny (u niektórych osób mniej), skąd pochodzi określenie rytm okołodobowy (Czeisler i in., 1999). Oznacza to, że u więk- 
szości występuje naturalna tendencja do coraz późniejszego chodzenia spać i wstawania. Aby móc funkcjonować z okołodobowym rytmem w równych 24 godzinach, należy oddziaływać na niego bodźcami środowiskowymi. Pośród czynników środowiskowych najistotniejsze dla funkcjonowania zegara biologicznego jest światło (Lewandowski, Chrobok, 2020). Konsekwencja oddziaływania światła na rytm okołodobowy jest synchronizowanie się ludzi do czasu słonecznego. W efekcie tego, osoby mieszkające na wschodzie danej strefy czasowej śpią we wcześniejszych godzinach niż osoby mieszkające na zachodzie (Roenneberg $\mathrm{i}$ in., 2007), nawet jeśli ich preferencje poranności-wieczorności są podobne (Jankowski, Vollmer, Linke, Randler, 2014). Najsilniejszy wpływ na zegar biologiczny ma światło niebieskie, które jest naturalnie emitowane przez słońce, ale również przez sztuczne źródła, włączając w to ekrany urządzeń multimedialnych. Niebieskie światło, poza silnym wpływem na rytm okołodobowy, wywołuje też natychmiastowe efekty w obszarach takich jak funkcje poznawcze, nastrój oraz fizjologiczne podłoże tych procesów (np. aktywność bioelektryczna mózgu; Siemiginowska, Golonka, Iskra-Golec, 2019). Niewystarczająca ilość światła w okresie zimowym w lokalizacjach odległych od równika może powodować, z jednej strony, sezonowe obniżenie nastroju (depresja zimowa), z drugiej zaś - związane z nim nasilenie ekspresji chronotypu (przede wszystkim wieczornego; Jankowski, 2017a).

Chronotyp w większości badań mierzony jest za pomocą samoopisowych kwestionariuszy, które wykazują trafność względem takich funkcji jak dobowa zmienność temperatury ciała (Roenneberg, Kumar, Merrow, 2007) czy aktywność motoryczna (Jankowski, 2016). W ostatnim czasie toczy się debata dotycząca tego, czy trafniej jest mierzyć chronotyp za pomoca pytań o preferowany czas podejmowania różnych aktywności, czy pytań o czas faktyczny (Roenneberg, 2015). W rzeczywistości kwestionariusze preferencji wykazują związki z faktycznym czasem występowania różnych aktywności (Randler, Jankowski, 2014) i mogą być trafniejsze w przypadku osób, które nie moga sobie pozwolić na funkcjonowanie zgodne ze swoim chronotypem (Groß, Fritschi, 2017). Wydaje się zatem, że narzędzie do pomiaru chronotypu powinno być dostosowane do specyfiki danej próby (Jankowski, 2017b).

Chronotyp wykazuje relacje $\mathrm{z}$ wieloma obszarami funkcjonowania psychicznego i społecznego, które to związki prawdopodobnie są dwukierunkowe, co oznacza, że nie tylko chronotyp wpływa na zachowanie, ale również podejmowana aktywność może oddziaływać na chronotyp. I tak osoby o chronotypach wieczornych częściej reagują złością (Jankowski, Linke, 2020), są mniej sumienne (Tsaousis, 2010), mają bardziej negatywny stosunek do upływu 
czasu (Pruszczak, Stolarski, Jankowski, 2018), częściej stosują środki psychoaktywne (Senyk, Jankowski, Cholii, 2020). Osoby wieczorne wykazują większy promiskuityzm (Randler, Jankowski, Rahafar, Díaz-Morales, 2016), którego nie można wytłumaczyć ich profilem osobowości (Díaz-Morales i in., 2019). Zgodność chronotypów w związku romantycznym ma znaczenie dla satysfakcji u kobiet (Jocz, Stolarski, Jankowski, 2018), które to preferują mężczyzn o chronotypie bardziej zbliżonym do ich własnego (Randler, Barrenstein, Vollmer, Díaz-Morales, Jankowski, 2014). Osoby o chronotypie wieczornym przejawiają też gorszy nastrój, szczególnie w godzinach porannych (Jankowski, 2011), który moga jednak regulować poprzez różnego typu aktywności, jak na przykład ćwiczenia fizyczne (Sławińska, Stolarski, Jankowski, 2019). Osoby o chronotypie porannym, w porównaniu do osób o chronotypie wieczornym, wykazują niższą inteligencję emocjonalną (Stolarski, Jankowski, 2015), chociaż wierza, że jest odwrotnie, co sugerują ich wyższe wyniki w samoopisowych skalach inteligencji emocjonalnej (Antúnez, Navarro, Adan, 2013). Inteligencja emocjonalna uczestniczy w regulacji dziennych zmian nastroju - u osób z jej wyższym poziomem zmiany nastroju podczas dnia są większe (Stolarski, Jankowski, Matthews, Kawalerczyk, 2016). Warto zaznaczyć, że w przypadku inteligencji ogólnej chronotypy, do pewnego stopnia, trafnie ocenią jej poziom u siebie (Zajenkowski, Jankowski, Stolarski, 2019).

U osób o chronotypie wieczornym często dochodzi do konfliktu między ich czasem biologicznym a czasem społecznym (społeczeństwo jest zorientowane porannie - godziny rozpoczęcia pracy i lekcji w szkole itp.), który to konflikt opisywany jest terminem „społeczny jetlag” (Wittmann, Dinich, Merrow, Roenneberg, 2006). Co ciekawe, społeczny jetlag występuje nie tylko u ludzi, ale również u zwierząt domowych (Randler, Díaz-Morales, Jankowski, 2018). Konsekwencje społecznego jetlagu sa podobne do tych wynikających z podróży z przekroczeniem stref czasowych, z tym że jetlag społeczny ma charakter chroniczny. Jego najbardziej widoczne konsekwencje obserwowalne są w zakresie rytmu snu-czuwania oraz jakości snu. Te mniej oczywiste dotyczą konsekwencji zdrowotnych, jak otyłość czy zaburzenia nastroju (Beauvalet $\mathrm{i}$ in., 2017). Ekstremalny chronotyp, który istotnie utrudnia wypełnianie ról społecznych diagnozowany jest jako zaburzenie okołodobowego rytmu snu i czuwania (Wichniak i in., 2017a). Forma poranna (zespół przyspieszonej fazy snu i czuwania) diagnozowany jest rzadziej niż forma wieczorna (zespół opóźnionej fazy snu i czuwania; Schrader, Bovim, Sand, 1993). W przypadku stwierdzenia problematycznego rytmu snu i czuwania mogą zostać podjęte oddziaływania terapeutyczne (Wichniak i in., 2017b). 


\section{FUNKCJONOWANIE INTELEKTUALNE CHRONOTYPÓW}

W badaniach pokazywano związki między chronotypem i rytmem snu-czuwania a sprawnościa intelektualną, oraz szerzej - w obszarze różnych procesów poznawczych. Można wyodrębnić tutaj trzy główne nurty badań: koncentracja na efekcie synchronizacji między porą dnia a chronotypem (May, 1999); traktowanie poziomu sprawności intelektualnej jako stałej cechy osób o danym chronotypie (tj. wyższa inteligencja osób o chronotypie wieczornym; Preckel, Lipnevich, Schneider, Roberts, 2011); analiza jakości snu oraz rytmu snu-czuwania w funkcjonowaniu poznawczym (Schmidt, Collette, Cajochen, Peigneux, 2007).

Efekt synchronizacji opisuje zależność pokazująca, że ludzie lepiej funkcjonują w swoich preferowanych godzinach (np. w godzinach porannych u osób o chronotypie porannym). Poczatkowe badania nad efektem synchronizacji (May, 1999) koncentrowały się głównie na różnicach między osobami w różnym wieku i pokazały, że efekt synchronizacji jest na tyle duży, że sprawność w zadaniach mierzacych myślenie abstrakcyjne na materiale słownym osób starszych i osób młodszych nie różniła się, jeśli obie grupy były testowane w godzinach rannych (dla młodych dorosłych, którzy są przeciętnie bardziej wieczorni niż osoby starsze, byłyby to godziny niezgodne $z$ ich domniemana preferencja). Godziny poranne były korzystniejsze dla chronotypów porannych (osób starszych), natomiast niekorzystne dla chronotypów wieczornych (studentów). W badaniach tych przyjęto, że dla osób o chronotypie porannym optymalna porą są godziny ranne, a dla chronotypów wieczornych godziny popołudniowe. Niedawne badanie (Delpouve, Schmitz, Peigneux, 2014) pokazało jednak znacznie większą rozpiętość godzin optymalnych i nieoptymalnych, w sytuacji gdy osoby badane mogły je wskazać samodzielnie. Co więcej, o ile chronotyp związany był z pora optymalna (chronotypy bardziej wieczorne wskazywały późniejsze godziny; $r=0,50$ ), to dla pory nieoptymalnej nie zaobserwowano korelacji z chronotypem. Powyższa obserwację można prawdopodobnie tłumaczyć tym, że ludzie potrafią trafnie wskazać godziny preferowane/niepreferowane wtedy, jeśli mogą wystarczająco często sprawdzić się w szerokim zakresie pór dnia.

Z kolei wyniki części badań sugerują, że kontrolując porę dnia, osoby o chronotypie wieczornym wykazują większą sprawność intelektualną. W metaanalizie serii badań z wykorzystaniem dwuwymiarowego kwestionariusza chronotypu, czynnik poranności uzyskał korelację $r=-0,04$, a czynnik wieczorności korelację $r=0,08$ z różnymi wskaźnikami sprawności intelektualnej (Preckel i in., 2011). Wyniki te pokazały, że omawiany związek może być 
bardzo słaby. Z kolei w badaniach z wykorzystaniem bardziej bezpośrednich miar inteligencji płynnej (Test matryc Ravena w wersji dla zaawansowanych) i skrystalizowanej (Test rozumowania werbalnego), związki wieczorności z inteligencja były nieznacznie wyższe i wnosiły 1-2\% wspólnej wariancji (wartości oszacowane na podstawie liczebności i poziomu istotności, gdyż autorzy nie podali dokładnej wielkości korelacji; Lázár i in., 2012). Jeszcze bardziej uderzające są wyniki wskazujące, że nawet w godzinach rannych chronotyp wieczorny związany jest z wyższą efektywnością w wykonaniu zadań angażujących pamięć operacyjna, będąca jednym z najistotniejszych aspektów inteligencji płynnej (Roberts, Kyllonen, 1999). Badania te kwestionuja znaczenie efektu synchronizacji i sugeruja, że chronotyp wieczorny jest związany z wyższą inteligencją, oraz że relacja ta jest niezależna od pory dnia. Wyniki te tłumaczone są efektem treningu w przezwyciężaniu codziennych trudności, na które wystawione są osoby o chronotypie wieczornym ze względu na funkcjonowanie w porannie zorientowanym społeczeństwie (Preckel i in., 2011). Wyniki te są również źródłem inspiracji dla teorii tłumaczących owe relacje w nurcie ewolucyjnym (Kanazawa, Perina, 2009), w których spekuluje się, że wysoka inteligencja sprzyjała podejmowaniu nowych wyzwań ewolucyjnych, spośród których jednym z ważniejszych było rozszerzenie aktywności do godzin nocnych, możliwe dzięki opanowaniu ognia.

Powyższe rozbieżności wyników wskazujących z jednej strony na efekt synchronizacji, z drugiej zaś - na przewagę intelektualną osób o chronotypie wieczornym niezależnie od pory dnia sugerują występowanie dodatkowych mechanizmów pośredniczących, których uwzględnienie może pozwolić odpowiedzieć na pytanie, w jakim stopniu poziom sprawności intelektualnej jest stała cechą chronotypu, a w jakim stopniu jest efektem oddziaływań innych, związanych z chronotypem zmiennych. Czynnikiem wartym rozpatrzenia w tym kontekście jest społeczny jetlag, który dopiero w połączeniu z nieoptymalną porą dnia może maskować przewagę intelektualną osób o chronotypie wieczornym. Mianowicie, społeczny jetlag ma wpływ na szereg charakterystyk rytmu snu-czuwania (m.in. obniżenie jakości snu, fragmentację rytmu snuczuwania), które to mogą oddziaływać na możliwości wykorzystania potencjału intelektualnego, co może być szczególnie widoczne w godzinach nieoptymalnych. I tak, na przykład, obniżona jakość snu (Yaffe, Falvey, Hoang, 2014), obniżona amplituda rytmu dobowego (Bromundt i in., 2011) czy zwiększona fragmentacja rytmu snu-czuwania (Oosterman i in., 2009) była łączona z obniżonym funkcjonowaniem poznawczym. Dodatkowo poranny szczyt poziomu kortyzolu, którego funkcją jest ułatwienie przejścia ze stanu snu do fazy 
aktywności, czemu sprzyja wyższy poziom tego hormonu, jest niższy u osób o chronotypie wieczornym w porównaniu do osób o preferencjach porannych. Badania sugeruja, że poranny poziom kortyzolu (CAR - cortisol awakening response) może być zaangażowany w sprawność poznawczą w godzinach rannych (Lupien $i$ in., 2002), chociaż nie przeprowadzono badań testujących bezpośrednio tę hipotezę.

Różnice między chronotypami oraz porami dnia w poziomie wykonania zadań mierzących inteligencję mogą być również pochodną różnic w zakresie innych procesów poznawczych, które wpływają na poziom wykonania zadań intelektualnych. Chociaż badań dotyczących chronopsychologicznych predyktorów funkcjonowania poznawczego jest wciąż niewiele, relatywnie duże zainteresowanie badaczy budzą procesy uwagowe, ze względu na ich podatność na zaburzenia rytmu snu-czuwania i znaczenie dla bezpieczeństwa pracy i ruchu drogowego (Jankowski, Zajenkowski, 2009). Badania te pokazują tym bardziej spójny obraz, im mniej złożony aspekt uwagi jest badany (Schmidt $\mathrm{i}$ in., 2007). I tak dla prostych procesów uwagowych godziny popołudniowo-wieczorne są bardziej sprzyjające niezależnie od chronotypu (Jankowski, Zajenkowski, 2016), a funkcjonowanie uwagi odgrywa rolę w poziomie wykonania testów inteligencji (Hutton, Wilding, Hudson, 1997).

\section{EFEKT SYNCHRONIZACJI W WARUNKACH NATURALNYCH}

Opisane powyżej badania były prowadzone głównie w warunkach laboratoryjnych, a opisane zjawiska charakteryzowały się niewielkimi siłami efektu. Powstaje zatem pytanie, czy przekładają się one na funkcjonowanie osób o odmiennych chronotypach w warunkach naturalnych. Aby przybliżyć odpowiedź na to pytanie, w ramach projektu realizowanego na Uniwersytecie Warszawskim przeprowadzono serię badań na uczniach szkół średnich. Miały one na celu sprawdzenie, czy w warunkach naturalnych wystapi efekt synchronizacji między porą dnia i chronotypem w poziomie wykonania zadań mierzących inteligencję (Goldstein i in., 2007), który to efekt będzie pochodną efektu synchronizacji, poziomu zaangażowania w wykonanie zadania poznawczego oraz społecznego jetlagu i niedoboru snu. Innymi słowy, sformułowano oczekiwanie, że w warunkach naturalnych (wymóg porannego wstania), w godzinach rannych osoby o chronotypie porannym będa przejawiały większą sprawność intelektualną niż osoby o chronotypie wieczornym ze względu na to, że osoby wieczorne będą wtedy wykazywały mniejsze zaangażowanie w wykonywanie zadań (poznawczych). W godzinach popołudniowych (fizjologicznie nie fa- 
woryzujących żadnego chronotypu) osoby o chronotypie wieczornym będa lepiej wykonywać zdania mierzące inteligencję niż te o chronotypie porannym, a różnice między chronotypami w poziomie zaangażowania nie wystąpia. Różnice między chronotypami w godzinach rannych w zakresie poziomu wykonania zadań mierzących inteligencję i zaangażowanie będą tłumaczone wielkością społecznego jetlagu i niedostatkiem snu. Chronotypy wieczorne będą doświadczały większego jetlagu i niedostatku snu (mediatory), które z kolei będą negatywnie wpływały na sprawność intelektualna. Pozytywna weryfikacja tej hipotezy byłaby argumentem wskazującym na prawdziwość tezy, że efekt synchronizacji obserwowany w warunkach naturalnych jest w istocie konsekwencją niekorzystnych następstw psychologicznych społecznego jetlagu.

W niniejszym rozdziale zaprezentowane zostaną wyniki jednego z tych badań. Jego celem było rozstrzygnięcie, czy efekt synchronizacji w zakresie inteligencji przestanie być widoczny przy kontroli negatywnych skutków społecznego jetlagu i niedoboru snu - niskiego poziomu zaangażowania w wykonywanie zadania. Przeprowadzono badanie, w którym inteligencja była mierzona dwukrotnie podczas dnia, z użyciem wersji alternatywnych testu inteligencji. Badanie zostało przeprowadzone na uczniach klas maturalnych szkoły średniej ze względu na naturalne warunki sprzyjające występowaniu społecznego jetlagu i niedoboru snu - rozwojowo uwarunkowaną maksymalną wieczorność występująca na tym etapie rozwoju osobniczego (Roenneberg i in., 2004) w połączeniu z narzuconym odgórnie porannym rozpoczęciem zajęć (mniej powszechnym wśród studentów uniwersytetów mających większą swobodę w kształtowaniu swojego rozkładu zajęć).

W badaniu uczestniczyło 93 uczniów szkoły średniej, z czego część była badana w kolejności rano-popołudnie, a część popołudnie-rano, podczas swojej pierwszej (lekcja nr 1 lub 2 w planie ogólnym) i ostatniej lekcji danego dnia (lekcja nr 7 lub 8). W badaniu został zmierzony chronotyp, społeczny jetlag i niedostatek snu (za pomocą Munich ChronoType Questionnaire; Roenneberg, Wirz-Justice, Merrow, 2003) oraz inteligencja płynna (przy użyciu Neutralnego kulturowo testu inteligencji; Cattell, 1961; Matczak, Martowska, 2013), jak również zmierzone zostało zaangażowanie w wykonanie testu inteligencji (przy użyciu Dundee Stress State Questionnaire; Matthews i in., 2002). Wyniki tego badania pokazały, że chronotyp nie korelował istotnie statystycznie z poziomem wykonania testu inteligencji zarówno w godzinach porannych, jak i wieczornych. Chronotyp nie korelował też z wielkością różnicy między poziomem wykonania testu inteligencji rano i jego poziomem wieczorem, a zatem badanie to nie wykazało istnienia efektu synchronizacji pory dnia z chronotypem u uczniów 
klas maturalnych. W badaniu tym poziom wykonania testu inteligencji nie był związany z żadną z mierzonych zmiennych, z kolei chronotyp wieczorny był związany z większym społecznym jetlagiem oraz większym martwieniem się wykonaniem testu inteligencji (aspekt zaangażowania w wykonanie testu). Należy mieć na uwadze niewielką liczbę uczestników. Dla liczebności próby w niniejszym badaniu można było wykryć jedynie korelacje powyżej 0,2 , a zatem słabe związki nie miały szansy uzyskania istotności statystycznej. Z drugiej strony, wynik ten jest zbieżny z doniesieniami z badań przeprowadzanych w klasie w podobnym schemacie (Randler, Bechtold, Vogel, 2016). Może to oznaczać, że efekt synchronizacji nie jest wystarczająco silny, aby ujawnić się w warunkach naturalnych, w których występuje więcej czynników zakłócających niż w laboratorium.

\section{PODSUMOWANIE}

Inteligencja tradycyjnie rozpatrywana jest jako względnie stały potencjał osobniczy do wykonywania złożonych zadań poznawczych. Z drugiej jednak strony, wykorzystanie tego potencjału zależeć może od różnych czynników, również o charakterze sytuacyjnym. Dotychczasowe badania nie daja jednoznacznej odpowiedzi na pytanie, w jaki sposób chronotyp, regulujący wpływ pory dnia na funkcjonowanie, związany jest ze sprawnością intelektualna. Część badań sugeruje, że osoby o chronotypie wieczornym, w porównaniu do osób o chronotypie porannym, wykazują większą sprawność w wykonywaniu zadań mierzących inteligencję płynną i skrystalizowaną niezależnie od pory dnia (mają większy potencjał intelektualny; Preckel, 2011), jednakże związki te są niewielkie, niekiedy poniżej granicy $1 \%$ wspólnej zmienności wyznaczającej praktyczne znaczenie odkryć. Z kolei badania skoncentrowane na analizie efektu synchronizacji (May, 1999) pokazują, że sprawność poznawcza w różnych typach zadań poznawczych wyższa jest w godzinach zgodnych z preferencjami dobowymi, co oznacza, że rano osoby o chronotypie porannym są sprawniejsze poznawczo od osób o późniejszych chronotypach (pośrednim, wieczornym), z kolei w godzinach późniejszych przewagę uzyskują osoby o chronotypie wieczornym (Goldstein i in., 2007). Rozstrzygnięcie powyższych sprzeczności wymaga dalszych badań, w szczególności odpowiedzi na pytania: (1) czy osoby o chronotypie wieczornym $\mathrm{w}$ istocie są bardziej inteligentne, (2) czy obserwowany w niektórych badaniach efekt synchronizacji jest pochodną braku dopasowania osób o chronotypie wieczornym do porannej organizacji życia społecznego (społeczny jetlag), (3) jakie mechanizmy psychologiczne i neurobehawioralne 
stoją u podłoża obserwowanych różnic w sprawności intelektualnej między chronotypami. Nie jest wykluczone, że różnice w sprawności intelektualnej między chronotypami zależne są z jednej strony od pory dnia, kiedy przeprowadzone jest badanie, $z$ drugiej zaś od jakości snu i charakterystyk rytmu snu-czuwania, będących pochodną społecznego jetlagu (Wittmann i in., 2006). Jeśli osoby o preferencjach wieczornych, w porównaniu do osób o chronotypie porannym, posiadaja większy potencjał intelektualny, to ich przewaga powinna być widoczna w godzinach porannych, po uwzględnieniu szeregu czynników, które w naturalnych warunkach oddziałują negatywnie na ich funkcjonowanie poznawcze (m.in. negatywy efekt społecznego jetlagu). Analizując różnice między chronotypami z uwzględnieniem godziny prowadzenia pomiaru, powinny być jednocześnie uwzględnione potencjalnie znaczące czynniki w postaci obniżonej jakości snu i przebiegu rytmu snu-czuwania będące efektem społecznego jetlagu, występującego częściej u osób o chronotypie wieczornym, jak również czynniki neuroanatomiczne oraz funkcjonowanie neuroendokrynologiczne. Innymi słowy, większy potencjał intelektualny osób o chronotypie wieczornym może być maskowany szeregiem czynników, których efekty ujawniaja się szczególnie mocno podczas nieoptymalnej pory dnia (godziny ranne). Zatem możliwe jest, że osoby o chronotypie wieczornym w istocie posiadaja większy potencjał intelektualny, którego wykorzystanie jest utrudnione w typowych warunkach (społecznych) ze względu na niekorzystny profil rytmu dobowego i jakości snu, które są pochodną między innymi społecznego jetlagu.

\section{BIBLIOGRAFIA}

Antúnez, J. M., Navarro, J. F., Adan, A. (2013). Circadian typology and emotional intelligence in healthy adults. Chronobiology International, 30, 981-987. https://doi. org/10.3109/07420528.2013.790397

Beauvalet, J. C., Quiles, C. L., de Oliveira, M. A. B., Ilgenfritz, C. A. V., Hidalgo, M. P. L., Tonon, A. C. (2017). Social jetlag in health and behavioral research: A systematic review. ChronoPhysiology and Therapy, 7, 19-31. https://doi.org/10.2147/ CPT.S108750

Bromundt, V., Köster, M., Georgiev-Kill, A., Opwis, K., Wirz-Justice, A., Stoppe, G., Cajochen, C. (2011). Sleep-wake cycles and cognitive functioning in schizophrenia. British Journal of Psychiatry, 198, 269-276. https://doi.org/10.1192/bjp. bp.110.078022

Cattell, R. B. (1961). Culture Free Intelligence Test, Scale 3. Champaign: Institute for Personality and Ability Testing. 
Czeisler, C. A., Duffy, J. F., Shanahan, T. L., Brown, E. N., Mitchell, J. F., Rimmer, D. W., ..., Dijk, D. J. (1999). Stability, precision, and near-24-hour period of the human circadian pacemaker. Science, 284(5423), 2177-2181. https://doi.org/10.1126/ science.284.5423.2177

Delpouve, J., Schmitz, R., Peigneux, P. (2014). Implicit learning is better at subjectively defined non-optimal time of day. Cortex, 58, 18-22. https://doi.org/10.1016/j. cortex.2014.05.006

Díaz-Morales, J. F., Jankowski, K. S., Prokop, P., Castellana, I., Linke, M., Randler, C., Rahafar, A. (2019). Sleep timing is linked to sociosexuality: Evidence from German, Polish, Slovak, and Spanish females. Time \& Society, 28(3), 1272-1287. https:// doi.org/10.1177/0961463X18757390

Goldstein, D., Hahn, C., Hasher, L., Cowell, J. M., Wiprzycka, U. J., Zelazo, P. D. (2007). Time of day, intellectual performance, and behavioral problems in morning versus evening type adolescents: Is there a synchrony effect? Personality and Individual Differences, 42, 431-440. https:/ / doi.org/10.1016/j.paid.2006.07.008

Groß, J. V., Fritschi, L. (2017). Complementing the social jet lag by considering pristine internal time. Chronobiology International, 34(9), 1177-1179. https://doi.org/1 0.1080/07420528.2017.1356328

Hutton, U., Wilding, J., Hudson, R. (1997). The role of attention in the relationship between inspection time and IQ in children. Intelligence, 24(3), 445-460. https:/ / doi.org/10.1016/S0160-2896(97)90059-3

Jankowski, K. S. (2008). Wielowymiarowy kwestionariusz do pomiaru różnic indywidualnych w zakresie zegara biologicznego. W: W. Ciarkowska, W. Oniszczenko (red.), Szkice zpsychologii różnic indywidualnych (s. 123-135). Warszawa: Scholar.

Jankowski, K. S. (2011). W rytmie nastroju. W: E. Goryńska, M. Ledzińska, M. Zajenkowski, (red.), Nastrój. Modele, geneza, funkcje (s. 55-72). Warszawa: Wydawnictwo Uniwersytetu Warszawskiego.

Jankowski, K. S. (2016). Validation of the Munich ChronoType Questionnaire against actigraphy. International Journal of Psychophysiology, 108, 149. https://doi. org/10.1016/j.ijpsycho.2016.07.433

Jankowski, K. S. (2017a). Morningness-eveningness and seasonality. Biological Rhythm Research, 48, 331-342. https://doi.org/10.1080/09291016.2016.1263001

Jankowski, K. S. (2017b). Actual versus preferred sleep times as a proxy of biological time for social jet lag. Chronobiology International, 34, 1175-1176. https://doi.org/1 0.1080/07420528.2017.1356663

Jankowski, K. S., Dmitrzak-Weglarz, M. (2017). ARNTL, CLOCK, and PER3 polymorphisms - links with chronotype and affective dimensions. Chronobiology International, 34, 1105-1113. https://doi.org/10.1080/07420528.2017.1343341 
Jankowski, K. S., Fajkowska, M., Domaradzka, E., Wytykowska, A. (2019). Chronotype, social jetlag and sleep loss in relation to sex steroids. Psychoneuroendocrinology, 108, 87-93. https://doi.org/10.1016/j.psyneuen.2019.05.027

Jankowski, K. S., Linke, M. (2020). Angry night birds: Emotionality, activity and sociability temperament in adolescent chronotypes. Chronobiology International, 37(5), 652-659. https://doi.org/10.1080/07420528.2020.1754844

Jankowski, K. S., Vollmer, C., Linke, M., Randler, C. (2014). Differences in sun time within the same time zone affect sleep-wake and social rhythms, but not morningness preference: Findings from a Polish-German comparison study. Time \& Society, 23, 258-276. https://doi.org/10.1177/0961463X14535911

Jankowski, K. S., Zajenkowski, M. (2009). Znaczenie rytmów dobowych i różnic indywidualnych w zakresie uwagi człowieka w bezpieczeństwie transportu drogowego. Journal of KONES, 16(3), 141-147.

Jankowski, K. S., Zajenkowski, M. (2016). The role of morningness and endurance in mood and attention during morning and evening hours. Journal of Individual Differences, 37, 73-80. https://doi.org/10.1027/1614-0001/a000189

Jocz, P., Stolarski, M., Jankowski, K. S. (2018). Similarity in chronotype and preferred time for sex and its role in relationship quality and sexual satisfaction. Frontiers in Psychology, 9, 443. https://doi.org/10.3389/fpsyg.2018.00443

Kanazawa, S., Perina, K. (2009). Why night owls are more intelligent. Personality and Individual Differences, 47, 685-690. https:/ / doi.org/10.1016/j.paid.2009.05.021

Koskenvuo, M., Hublin, C., Partinen, M., Heikkilä, K., Kaprio, J. (2007). Heritability of diurnal type: A nationwide study of 8753 adult twin pairs. Journal of Sleep Research, 16, 156-162. https://doi.org/10.1111/j.1365-2869.2007.00580.x

Lázár, A. S., Slak, A., Lo, J. C. Y., Santhi, N., von Schantz, M., Archer, S. N., ..., Dijk, D. J. (2012). Sleep, diurnal preference, health, and psychological well-being: A prospective single-allelic-variation study. Chronobiology International, 29(2), 131-146. https://doi.org/10.3109/07420528.2011.641193

Lehmann, M., Spoelstra, K., Visser, M. E., Helm, B. (2012). Effects of temperature on circadian clock and chronotype: An experimental study on a passerine bird. Chronobiology International, 29(8), 1062-1071. https://doi.org/10.3109/0742 0528.2012.707159

Lewandowski, M., Chrobok, Ł. (2020). Wielo-oscylatorowa teoria mechanizmu zegara biologicznego ssaków. Kosmos, 69(1), 91-103. https://doi.org/10.36921/ kos.2020_2622.

Lupien, S. J., Wilkinson, C. W., Briere, S., Menard, C., Ng Ying Kin, N. M. K., Nair, P. V. (2002). The modulatory effects of corticosteroids on cognition: Studies 
in young human populations. Psychoneuroendocrinology, 27, 401-416. https://doi. org/10.1016/s0306-4530(01)00061-0

Matczak, A., Martowska, K. (2013). CFT3 Neutralny kulturowo test inteligencji-Wersja 3 Raymonda B. Cattella i Alberty K. S. Cattell. Warszawa: Pracownia Testów Psychologicznych PTP.

Matthews, G., Campbell, S. E., Falconer, S., Joyner, L., Huggins, J., Gilliland, K., ..., Warm, J. S. (2002). Fundamental dimensions of subjective state in performance settings: Task engagement, distress and worry. Emotion, 2, 315-340. https://doi. org/10.1037/1528-3542.2.4.315

May, C. P. (1999). Synchrony effects in cognition: The costs and a benefit. Psychonomic Bulletin \& Review, 6, 142-147. https://doi.org/10.3758/BF03210822

Oosterman, J. M., van Someren, E. J. W., Vogels, R. L. C., van Harten, B., Scherder, E. J. A. (2009). Fragmentation of the rest-activity rhythm correlates with age-related cognitive deficits. Journal of Sleep Research, 18, 129-135. https://doi.org/10.1111/ j.1365-2869.2008.00704.x

Pedrazzoli, M., Secolin, R., Esteves, L. O. B., Pereira, D. S., Koike, B. V., Louzada, F. M., Tufik, S. (2010). Interactions of polymorphisms in different clock genes associated with circadian phenotypes in humans. Genetics and Molecular Biology, 33, 627-632. https://doi.org/10.1590/S1415-47572010005000092.

Preckel, F., Lipnevich, A. A., Schneider, S., Roberts, R. D. (2011). Chronotype, cognitive abilities, and academic achievement: A meta-analytic investigation. Learning and Individual Differences, 21, 483-492. https://doi.org/10.1016/j.lindif.2011.07.003

Pruszczak, D., Stolarski, M., Jankowski, K. S. (2018). Chronotype and time metaphors: Morning-types conceive time as more friendly and less hostile. Biological Rhythm Research, 49, 431-441. https://doi.org/10.1080/09291016.2017.1368215

Randler, C., Barrenstein, S., Vollmer, C., Díaz-Morales, J. F., Jankowski, K. S. (2014). Women would like their partners to be more synchronized with them in their sleep-wake rhythm. The Spanish Journal of Psychology, 17, E70. https://doi. org/10.1017/sjp.2014.72

Randler, C., Bechtold, K., Vogel, M. (2016). Chronotype and time of day do not influence mathematical achievement in standardised tests, but impact on affect-results from a field experiment. International Online Journal of Educational Sciences, 8(5), 54-61. https://doi.org/10.15345/iojes.2016.05.006

Randler, C., Díaz-Morales, J. F., Jankowski, K. S. (2018). Synchrony in chronotype and social jetlag between dogs and humans across Europe. Time \& Society, 27(2), 223-238. https://doi.org/10.1177/0961463X15596705

Randler, C., Jankowski, K. S. (2014). Evidence for the validity of the Composite Scale of Morningness based on students from Germany and Poland - relationship with 
sleep wake and social schedules. Biological Rhythm Research, 45, 635-659. https:/ / doi.org/10.1080/09291016.2014.884307

Randler, C., Jankowski, K. S., Rahafar, A., Díaz-Morales, J. F. (2016). Sociosexuality, morningness-eveningness, and sleep duration. SAGE Open, 6, 1-8. https://doi. org/10.1177/2158244015621958

Roberts, R. D., Kyllonen, P. C. (1999). Morningness-eveningness and intelligence: Early to bed, early to rise will likely make you anything but wise! Personality and Individual Differences, 27, 1123-1133. https:/ / doi.org/10.1016/s0191-8869(99)00054-9

Roenneberg, T. (2015). Having trouble typing? What on earth is chronotype? Journal of Biological Rhythms, 30(6), 487-491. https://doi.org/10.1177/0748730415603835

Roenneberg, T., Kuehnle, T., Pramstaller, P. P., Ricken, J., Havel, M., Guth, A., Merrow, M. (2004). A marker for the end of adolescence. Current Biology, 14(24), R1038-R1039. https://doi.org/10.1016/j.cub.2004.11.039

Roenneberg, T., Kumar, C. J., Merrow, M. (2007). The human circadian clock entrains to sun time. Current Biology, 17(2), R44-R45. https://doi.org/10.1016/j. cub.2006.12.011

Roenneberg, T., Wirz-Justice, A., Merrow, M. (2003). Life between clocks: Daily temporal patterns of human chronotypes. Journal of Biological Rhythms, 18(1), 80-90. https://doi.org/10.1177/0748730402239679

Schmidt, C., Collette, F., Cajochen, C., Peigneux, P. (2007). A time to think: Circadian rhythms in human cognition. Cognitive Neuropsychology, 24, 755-789. https://doi. org/10.1080/02643290701754158

Schrader, H., Bovim, G., Sand, T. (1993). The prevalence of delayed and advanced sleep phase syndromes. Journal of Sleep Research, 2(1), 51-55. https://doi. org/10.1111/j.1365-2869.1993.tb00061.x

Senyk, O., Jankowski, K. S., Cholii, S. (2020). Ukrainian versions of the Composite Scale of Morningness and Munich ChronoType Questionnaire. Biological Rhythm Research. Advance online publication. https://doi.org/10.1080/09291016.2020.1 788807

Siemiginowska, P., Golonka, K., Iskra-Golec, I. (2019). Wpływ monochromatycznego światła niebieskiego na aktywność EEG: Rola elastyczności nawyków snu. Polskie Forum Psychologic₹ne, 24(2), 168-183. https://doi.org/10.14656/PFP20190202

Sławińska, M., Stolarski, M., Jankowski, K. S. (2019). Effects of chronotype and time of day on mood responses to crossfit training. Chronobiology International, 36(2), 237-249. https://doi.org/10.1080/07420528.2018.1531016

Stolarski, M., Jankowski, K. S. (2015). Morningness-eveningness and performance-based emotional intelligence. Biological Rhythm Research, 46, 417-423. https://doi.org/10.1080/09291016.2015.1020199 
Stolarski, M., Jankowski, K. S., Matthews, G., Kawalerczyk, J. (2016). Wise „birds” follow their clock: The role of emotional intelligence and morningness-eveningness in diurnal regulation of mood. Chronobiology International, 33, 51-63. https:// doi.org/10.3109/07420528.2015.1115413

Tsaousis, I. (2010). Circadian preferences and personality traits: A meta-analysis. European Journal of Personality: Published for the European Association of Personality Psychology, 24(4), 356-373. https://doi.org/10.1002/per.754

Wichniak, A., Jankowski, K. S., Skalski, M., Skwarło-Sońta, K., Zawilska, J. B., Zarowski, M., ..., Jernajczyk, W. (2017a). Standardy leczenia zaburzeń rytmu okołodobowego snu i czuwania opracowane przez Polskie Towarzystwo Badań nad Snem i Sekcję Psychiatrii Biologicznej Polskiego Towarzystwa Psychiatrycznego. Część I. Fizjologia, metody oceny i oddziaływania terapeutyczne. Psychiatria Polska, 51, 793-814. https://doi.org/10.12740/PP/OnlineFirst/66810

Wichniak, A., Jankowski, K. S., Skalski, M., Skwarło-Sońta, K., Zawilska, J. B., Żarowski, M., ..., Jernajczyk, W. (2017b). Standardy leczenia zaburzeń rytmu okołodobowego snu i czuwania Polskiego Towarzystwa Badań nad Snem i Sekcji Psychiatrii Biologicznej Polskiego Towarzystwa Psychiatrycznego. Część II. Diagnoza i leczenie. Psychiatria Polska, 51, 815-832. https://doi.org/10.12740/ PP/68918

Wittmann, M., Dinich, J., Merrow, M., Roenneberg, T. (2006). Social jetlag: Misalignment of biological and social time. Chronobiology International, 23(1-2), 497-509. https://doi.org/10.1080/07420520500545979

Yaffe, K., Falvey, C. M., Hoang, T. (2014). Connections between sleep and cognition in older adults. Lancet Neurology, 13, 1017-1028. https://doi.org/10.1016/S14744422(14)70172-3

Zajenkowski, M., Jankowski, K. S., Stolarski, M. (2019). Why do evening people consider themselves more intelligent than morning individuals? The role of big five, narcissism, and objective cognitive ability. Chronobiology International, 36(12), 1741-1751. https://doi.org/10.1080/07420528.2019.1680559 



\section{1.}

\section{Inteligencja \\ a funkcjonowanie \\ w bliskich związkach}

Maria Leniarska (iD https://orcid.org/0000-0001-7443-3624

Uniwersytet Warszawski, Wydział Psychologii

maria.leniarska@psych.uw.edu.pl

Marcin Zajenkowski iD https://orcid.org/0000-0001-8669-4231

Uniwersytet Warszawski, Wydział Psychologii 
W powszechnym ujęciu oczywiste może wydawać się, że wysoka inteligencja jest kluczem do szeroko rozumianego sukcesu życiowego. Wiele badań wskazuje, że inteligentna osoba lepiej radzi sobie w szkole, na studiach, a następnie w pracy (np. Gottfredson, 2004). Co jednak w sytuacji, kiedy inteligentna osoba wyjdzie czasem z pracy i zapragnie kogoś poznać, umówić się na randkę albo stworzyć z kimś dłuższy związek? O ile znaczenie wysokiej inteligencji w sferze szkolnej czy zawodowej nie pozostawia wątpliwości, o tyle jej rola w sferze uczuć i emocji wydaje się bardziej zagadkowa. Od wieków w literaturze sfery serca (uczuć) i rozumu (inteligencji) są prezentowane jako niemalże przeciwstawne, których nie da się pogodzić. Dzisiejsze dociekania naukowe dostarczają jednak argumentów za tym, że i w poszukiwaniach towarzysza lub towarzyszki życia inteligencja ma swój istotny udział.

\section{INTELIGENTNA DRUGA POŁÓWKA - CZY NA PEWNO JEJ SZUKAMY?}

W kulturze popularnej, na przykład w kolorowych czasopismach czy chętnie oglądanych serialach, często zwraca się uwagę na wygląd i atrakcyjność fizyczną jako podstawowy czynnik dobierania się ludzi w pary. Okazuje się jednak, że inteligencja partnera/partnerki również odgrywa dużą rolę i jest wskazywana, zarówno przez kobiety, jak i przez mężczyzn, jako cecha wysoce pożądana u potencjalnego partnera/partnerki (Buss i in., 1990; Regan, Levin, Sprecher, Christopher, Gate, 2000). Co ciekawe, w niedawnym badaniu Gignac, Darbyshire i Ooi (2018) postanowili sprawdzić, czy istnieje zjawisko nazwane przez nich „,sapioseksualnością, opisujące osoby, dla których najbardziej pociagająca cecha partnera/partnerki jest właśnie poziom IQ. Po pierwsze, autorzy potwierdzili, że inteligencja jest druga, zaraz po byciu wyrozumiałym, cechą pożądaną u partnera/partnerki, z którym/a badani chcieliby stworzyć długotrwały związek. Wysoka inteligencja okazała się ważniejsza nawet niż zdrowie czy atrakcyjność fizyczna. Ten wynik sugeruje zatem, że inteligencja rzeczywiście wydaje się większości ludzi ważną cechą u potencjalnego partnera/part- 
nerki. Po drugie, dalsze dociekania w tym zakresie wskazały na interesujące zależności. Okazuje się bowiem, że istnieje górna granica poziomu IQ, która wydaje się ludziom atrakcyjna. Jako najbardziej pożądany poziom IQ, ludzie uznali 120 punktów, co odpowiada 90 centylowi (jedynie 10\% osób posiada wyższy poziom). Natomiast ekstremalnie wysoki poziom IQ, czyli 135 i więcej (99. centyl) nie wydawał się już tak pociagający, podobnie jak niższe poziomy IQ. Badacze postawili hipotezę progu, zgodnie, z którą wraz ze wzrostem IQ rośnie atrakcyjność partnera/partnerki, jednakże istnieje pewien poziom (próg) IQ powyżej, którego druga osoba nie jawi się już tak pociagająca. Być może wiąze się to z rozpowszechnionym przekonaniem, że ekstremalnie wysoki poziom inteligencji wiąże się z zaburzeniami w funkcjonowaniu społecznym, co jednak nie wydaje znajdować potwierdzenia w istniejących danych (Makel, Kell, Lubinski, Putallaz, Benbow, 2016).

Być może z powyższych powodów ludzie zazwyczaj nie poszukuja geniuszy, ale osób zbliżonych do nich pod względem inteligencji. Zjawisko to znane jest pod angielskim terminem assortative mating, co określa celowy dobór w pary, który oznacza, że przy wyborze partnera/partnerki kierujemy się określonymi cechami (Jensen, 1967). W codziennym życiu ludzie dobierają się zazwyczaj na zasadzie podobieństwa w odniesieniu do wielu cech zarówno fizycznych, jak i psychologicznych. Największą zbieżność między partnerami wykazano w zakresie wieku (Verbakel, Kalmijn, 2014), postaw politycznych i religijnych, edukacji, inteligencji i cech osobowości (Watson i in., 2004). Większe podobieństwo w związku łączy się zazwyczaj z wyższym zadowoleniem i jakościa związku (Luo, Klohnen, 2005; Schmitt, 2002).

Podobieństwo między partnerami odnotowano w przypadku wielu podstawowych cech osobowości, takich jak np. otwartość, ugodowość czy sumienność (Botwin, Buss, Shackelford, 1997; McCrae, 1996; McCrae i in., 2008; Watson, Hubbard, Wiese, 2000; Watson i in., 2004). Co ciekawe jednak, ludzie maja również tendencję do poszukiwania partnerów/partnerek podobnych do nich pod względem społecznie niepożądanych cech, takich jak neurotyczność czy zaburzenia psychiczne (Mathews, Reus, 2001), a nawet tendencji do antyspołecznych zachowań i cech z tzw. Mrocznej Triady (psychopatii, makiawelizmu i narcyzmu; Kardum, Hudek-Knezevic, Schmitt, Covic, 2017). Wydaje się zatem, że spójność między partnerami jest bardzo ważnym czynnikiem determinującym to, z kim stworzymy związek. Jak wspomnieliśmy wcześniej, jedną z ważnych cech w tym kontekście jest inteligencja.

Jeżeli mielibyśmy pomyśleć o naszych najbliższych osobach, na dobór których mieliśmy wpływ, czyli np. o małżonku/małżonce, partnerze/part- 
nerce, czy przyjacielu/przyjaciółce), to zapewne okaże się, że w większości przypadków są to osoby o podobnym poziomie wykształcenia do naszego. Rzeczywiście, korelacja między inteligencją osób w bliskich związkach jest pozytywna i szacuje się ją na ok. 0,30-0,40 (Gignac, Zajenkowski, 2019; Van Leeuwen, Van den Berg, Boomsma, 2008; Watson i in., 2004). Pewne dane wskazują na to, że efekt ten może być większy w przypadku inteligencji werbalnej niż niewerbalnej (Watson $i$ in., 2004), choć nie jest to wynik jednoznaczny (Escorial, Martin-Buro, 2012). Jedno z zasadniczych pytań nad zjawiskiem podobieństwa wśród par dotyczy jego źródła. Z jednej strony, zbieżność między partnerami może być spowodowana tym, że ludzie na samym początku selekcjonują osoby, z którymi chcieliby pójść na randkę, a później się związać. W ten sposób już na wstępie dokonywana byłaby selekcja odpowiedniego kandydata/kandydatki na męża, czy żonę. Z drugiej strony, możliwe jest, że ludzie wraz z upływem czasu upodabniają się do siebie. Ta hipoteza może dotyczyć zarówno cech osobowości, np. osoba introwertyczna może stawać się bardziej towarzyska pod wpływem swojej partnerki i vice versa, jak i inteligencji - partnerzy mogą się nawzajem stymulować intelektualnie i zbliżać do siebie pod względem zdolności poznawczych. Badania wykazuja jednak, że staż związku nie modyfikuje korelacji między cechami partnerów, również jeżeli chodzi o inteligencję (Mascie-Taylor, 1989). Oznacza to, że mamy tendencję do wybierania podobnych do nas osób już na wczesnym etapie umawiania się i budowania związku. Te wyniki sugeruja, że ludzie potrafią ocenić poziom inteligencji innej osoby. Powstaje jednak pytanie, jaki jest stopień trafności takiej oceny.

\section{CZY POTRAFIMY OCENIĆ INTELIGENCJĘ PARTNERA/PARTNERKI?}

Badania pokazuja, że ludzie są w stanie w pewnym stopniu trafnie oszacować poziom inteligencji innej osoby, nawet gdy widzą ją po raz pierwszy w życiu przez krótką chwilę (Borkenau, Liebler, 1993). Badaczy szczególnie interesowała kwestia, czy osoby będące w związkach są w stanie adekwatnie ocenić IQ swojego partnera/partnerki. Pojawiły się różne teorie, często odwołujące się do psychologii ewolucyjnej, opisujące omawiane zjawisko wśród par heteroseksualnych. Jedna z koncepcji doboru seksualnego znana pod nazwą „mężczyźni rywalizuja/kobiety wybieraja” zakłada, że płeć żeńska powinna być lepsza w rozpoznawaniu cech partnera (Darwin, 1871; Stewart-Williams, Thomas, 2013). Zgodnie z tym ujęciem, mężczyźni mają prezentować swoje zalety, a kobieta ma wybrać spośród nich tego najlepszego, który będzie najwłaściwszym ojcem ich wspólnego potomstwa. Zdaniem zwolenników tego 
podejścia, ewolucja wyposażyła kobiety w lepszą umiejętność oceny potencjału partnera właśnie po to, by nie popełnić błędu w wyborze najlepszego partnera. Na podstawie tej teorii można zatem wnioskować, że kobiety będą bardziej trafnie oceniać rzeczywistą inteligencję partnerów.

Inna teoria postuluje, że kobiety i mężczyźni tak samo trafnie postrzegaja cechy partnera czy partnerki (Stewart-Williams, Thomas, 2013). Według tego podejścia różnice międzypłciowe w inwestowaniu w potomstwo są relatywnie niewielkie, a co za tym idzie, dobór partnera/partnerki, powinien być tak samo ważny dla kobiety, jak i mężczyzny. Inne argumenty przemawiające za tym modelem wiążą się z faktem, że mężczyźni również zwracają uwagę na różne cechy partnerek, np. atrakcyjność fizyczną (np. Furnham, 2009). Wreszcie okazuje się, że obie płcie podobnie wysoko lokują inteligencję jako cechę potencjalnego partnera/partnerki (Gignac i in., 2018). Zgodnie zatem z tą koncepcją, kobiety i mężczyźni powinni wykazywać podobną umiejętność oceny inteligencji swoich partnerów/partnerek.

Co pokazują badania? Po pierwsze, okazuje się, że więcej przemawia na korzyść drugiego modelu, tzn. braku różnic międzypłciowych. Na przykład, Gignac i Zajenkowski (2019) przebadali 218 par heteroseksualnych. Każda z osób wypełniała test inteligencji, szacowała własną inteligencję i inteligencje partnera/partnerki. Wyniki wykazały, że pomimo tego, że wśród kobiet korelacja ich oszacowania z rzeczywistym IQ partnera była nieco wyższa niż wśród mężczyzn, to jednak ta różnica nie była istotna statystycznie. Ponadto, badanie to pokazało, że obie osoby w parze znacząco przeszacowywały inteligencję swojego partnera, czy swojej partnerki. Innymi słowy, badani widzieli swoją druga połówkę w nierealistycznym, nazbyt optymistycznym świetle. Co ciekawe, badani spostrzegali partnerów/partnerki nawet bardziej pozytywnie niż samych siebie (więcej o tym badaniu zob. w rozdziale o przekonaniach na temat inteligencji). Te wyniki są spójne z innymi badaniami, wskazującymi, że mamy tendencję do postrzegania partnerów/partnerki pozytywniej niż siebie i niż sugerowałaby rzeczywistość. Efekt ten wykazano np. w odniesieniu do atrakcyjności fizycznej (np. Swami, Furnham, Georgiades, Pang, 2007).

Z przedstawionych wyżej badań wynika, że ludzie poszukują osób podobnych do siebie pod względem wielu cech, włączając w to inteligencję. Ponadto osoby w bliskim związku potrafią również w pewnym stopniu trafnie oszacować IQ partnera/partnerki. Powstaje pytanie, jakie są tego konsekwencje dla jakości związku. Niektórzy badacze sugerują, że podobieństwo pomiędzy partnerami powinno się przekładać na wyższe zadowolenie $z$ relacji z druga osoba (np. Gonzaga, Campos, Bradbury, 2007; Huston, Houts, 1998). Jak się okazuje 
jednak, efekt ten nie odnosi się do inteligencji, choć dane w tym zakresie są raczej skromne. W niewielu badaniach, w których badano satysfakcję ze związku oraz obiektywną inteligencję (np. testem Ravena lub testem Wechslera, a więc uznanymi narzędziami do pomiaru IQ) osób w związku, nie wykazano istotnej korelacji pomiędzy podobieństwem partnerów a poziomem zadowolenia ze związku (Gignac, Zajenkowski, 2019; Watson i in., 2004). Co prawda, w tym obszarze z pewnością potrzebne są dalsze badania, jednakże dostępne dane sugerują, że zbieżność w parze pod względem IQ niekoniecznie przekłada się na ogólne zadowolenie ze związku. Być może zatem dobieranie się w pary na podstawie inteligencji pełni inną funkcję, np. związaną z odziedziczalnością. Jeżeli natomiast chodzi o jakość związku, to, jak się okazuje, większe znaczenie niż inteligencja ogólna może tu ogrywać pewien specyficzny rodzaj inteligencji, jakim jest inteligencja emocjonalna.

\section{KONCEPCJA INTELIGENCJI EMOCJONALNEJ}

W ostatniej dekadzie XX wieku rozpowszechniło w psychologii pojęcie inteligencji emocjonalnej. Refleksje na temat umiejętności rozumienia emocji, radzenia sobie z nimi i czerpania z nich informacji miały swój początek znacznie wcześniej, kiedy badacze dyskutowali nad strukturą samej inteligencji. Starano się wówczas umiejscowić wśród wielu innych rodzajów tę inteligencję, która pomaga nam lepiej radzić sobie z emocjami i dzięki temu jeszcze lepiej przystosowuje nas do rzeczywistości (Gardner, 1983; Thorndike, Stein, 1937, za: Salovey, Mayer, 1990). Wkrótce badania nad różnymi aspektami inteligencji zaczęły się specjalizować w konkretnych dziedzinach, między innymi właśnie w tej związanej z emocjami, którą nazwano inteligencją emocjonalna. Pojawily się trzy główne nurty w rozumieniu inteligencji emocjonalnej: jako zdolności, jako cechy i jako kompetencji.

Przedstawiciele pierwszego podejścia, Salovey i Mayer (1990), opisali inteligencję emocjonalną jako zdolność, czyli potencjał człowieka (Matczak, Knopp, 2013). Zdolność ta miała dotyczyć monitorowania uczuć swoich oraz innych osób, rozróżniania emocji oraz czerpania z nich informacji przydatnych w myśleniu i postępowaniu jednostki (Salovey, Mayer, 1990). Inteligencja emocjonalna w tym ujęciu ujmowana jest podobnie do inteligencji poznawczej i badana również za pomocą narzędzi podobnych do testów IQ, czyli takich, w których prezentowane są zadania z poprawnymi i błędnymi odpowiedziami. Goleman (1999) natomiast opisuje inteligencję emocjonalną jako kompetencję, czyli w przeciwieństwie do zdolności - nie jako potencjał, ale aktualne, już 
posiadane umiejętności. Bar-On (1997) czy Petrides i Furnham (2001) rozumieją inteligencję emocjonalną jako pewną cechę osobowości dającą poczucie skuteczności emocjonalnej. W tym ujęciu jest ona badana za pomocą samoopisowych narzędzi podobnych do kwestionariuszy osobowości. W badaniach naukowych dominują dwa podejścia: zdolnościowe i cechowe. W niniejszym rozdziale przyjrzymy się przede wszystkim temu pierwszemu jako najbliższemu inteligencji poznawczej.

Salovey i Mayer (1990) wyróżnili cztery główne składowe inteligencji emocjonalnej. Po pierwsze, badacze wyodrębniają zdolności do spostrzegania emocji, czyli umiejętności rozpoznawania emocji we własnych stanach fizjologicznych, doznaniach i myślach. Jest to najwcześniej pojawiająca się w rozwoju zdolność emocjonalna. Następnie pojawia się umiejętność rozpoznawania emocji u innych osób (na podstawie intonacji, zachowania itp.) i w otoczeniu, np. w dziełach sztuki. Rozumiemy, że określony ton głosu może oznaczać pochwałę lub dezaprobatę, a wyraz twarzy mówcy i jego postawa ciała dodatkowo potwierdza fakt. Wreszcie, na omawianą zdolność składa się umiejętność adekwatnego wyrażania emocji oraz związanych z nimi potrzeb.

Druga zdolnością wyróżnioną w modelu Saloveya i Mayera (1990) jest zdolność do emocjonalnego wspomagania myślenia, czyli wiedza na temat tego, które emocje sprzyjaja, a które przeszkadzają określonym procesom poznawczym (np. uczeniu się, podejmowaniu decyzji itp.). Ponadto opisuje ją umiejętność przyjmowania różnych perspektyw oraz wywoływania w sobie określonych emocji w celu lepszego zrozumienia sytuacji mającej miejsce w przeszłości, teraźniejszości lub przyszłości.

Trzecią składową inteligencji emocjonalnej jest zdolność do rozumienia emocji oraz wykorzystywania wiedzy emocjonalnej. Charakteryzuje ja umiejętność nazywania emocji oraz rozumienia relacji między językiem a treściami emocjonalnymi, które odnoszą się do określonych słów oraz umiejętność interpretacji emocji. Ponadto omawiana zdolność obejmuje rozumienie złożonych uczuć (np. miłości, troski itp.) oraz zmiany ich natężenia pod wpływem określonych wydarzeń.

Jako czwartą, Salovey i Mayer (1990) wymieniaja zdolność do kontrolowania i regulowania emocji, która odnosi się do umiejętnego wpływania na emocje własne i innych ludzi w celu uzyskania określonego efektu, np. poprawienia nastroju, opanowania gniewu, uspokojenia się itp.

Podsumowując, osoba z wysoką inteligencją emocjonalną potrafi adekwatnie spostrzegać emocje, rozumieć je, nazywać i na ich podstawie wyciagać wnioski o sytuacji, w której jest, była lub będzie. Ponadto umie ocenić, jak 
emocje wpływają na nią samą i innych oraz jest zdolna skutecznie oddziaływać na poziom tych emocji.

\section{RÓŻNICE MIĘDZYPŁCIOWE}

W potocznym ujęciu większe zdolności emocjonalne przypisuje się kobietom. Rzeczywiście, przewagę kobiet w zakresie inteligencji emocjonalnej potwierdzają liczne badania (np. Brackett, Warner, Bosco, 2005). Część badań pokazuje, że kobiety uzyskują wyższe wyniki od mężczyzn na każdym z podwymiarów inteligencji emocjonalnej (Śmieja, Stolarski, 2018), a także ogólnie odznaczają się większą świadomością emocjonalną (Barrett, Lane, Sechrest, Schwartz, 2000). Ponadto inne badania pokazują, że kobiety przejawiają większe zdolności w zakresie rozpoznawania sygnałów niewerbalnych oraz rozpoznawania emocji (Brody, Hall, 2005; Hall, Matsumoto, 2004), jednak przewaga ta ma dotyczyć jedynie emocji pozytywnych (Kirouac, Dore, 1985; Matczak, Piekarska, Studniarek, 2005). Mężczyźni wykazują lepsze umiejętności rozpoznawania emocji negatywnych (Elfenbein, Marsh, Ambady, 2002). Wiedza o różnicach między kobietami i mężczyznami w zakresie inteligencji emocjonalnej wydaje się być ważna w kontekście funkcjonowania w związu, a nawet już na etapie dobierania się w pary.

\section{INTELIGENCJA EMOCJONALNA A DOBIERANIE SIĘ W PARY}

Podobnie jak w przypadku inteligencji poznawczej również wysoka inteligencja emocjonalna wydaje się być pożądaną cechą u partnera. Przykładowo w badaniu przeprowadzonym przez Magdalenę Śmieję (2018) w hierarchii cech idealnego partnera inteligencja emocjonalna zajęła trzecie miejsce (po byciu godnym zaufania i inteligencji ogólnej), ale warto zaznaczyć, że grupę osób badanych stanowiły tylko kobiety. W grupie mężczyzn inteligencja emocjonalna uplasowała się nieco niżej, ale nadal wysoko - na piątym miejscu, po byciu godnym zaufania, inteligencji ogólnej, wesołym usposobieniu i atrakcyjności (Śmieja, 2018). Inteligencja emocjonalna jest więc pożądana u potencjalnych partnerów. Powstaje pytanie, w jakim stopniu inteligencja emocjonalna ma znaczenie przy rzeczywistym dobieraniu się w pary. Jak wspomnieliśmy wyżej, w psychologii stwierdzono istnienie celowego doboru w pary, np. pod względem cech osobowości (McCrae i in., 2008; Watson i in., 2004) czy poziomu inteligencji (Gignac, Zajenkowski, 2019), ale czy występuje on również w przypadku inteligencji emocjonalnej? Niektóre badania wskazują, że faktycz- 
nie inteligencja emocjonalna jest kolejnym ważnym czynnikiem przy doborze w pary, zaobserwowano bowiem dodatnią korelację $(r=0,27)$ pomiędzy poziomami inteligencji emocjonalnej osób będących w związku (Śmieja, Stolarski, 2018). Dodatkowo okazuje się, że zdolności percepcji emocji, są tymi, które najlepiej przewiduja poziom inteligencji emocjonalnej u partnera - zarówno w grupie kobiet, jak i mężczyzn. Ponadto u mężczyzn podkreśla się znaczenie zarządzania emocjami. Mężczyźni o lepszej percepcji emocji i zdolnościach zarządzania nimi dobierają się w pary z partnerkami o podobnie wysokich zdolnościach w tym zakresie (Śmieja, Stolarski, 2016). Inne badania pokazuja, że również na bardziej świadomym poziomie ludzie szukają kogoś o podobnym poziomie inteligencji emocjonalnej. Osoby, które wyżej oceniały swoje zdolności w zakresie tej charakterystyki, bardziej też ceniły je u partnera/partnerki (Śmieja, 2018). Warto jednak zauważyć, że część z badań nie potwierdziła związku między poziomem inteligencji emocjonalnej partnerów (Leniarska, 2020; Zeidner, Kaluda, 2008; Zeidner, Kloda, Matthews, 2013).

\section{INTELIGENCJA EMOCJONALNA A KONFLIKTY W ZWIĄZKU}

Ważne pytanie na temat inteligencji emocjonalnej dotyczy tego, jaką rolę ogrywa ona w związku. Tym, co może być zagrażające dla związku, wydają się konflikty. Badania pokazuja, że w parach małżeńskich komunikaty niewerbalne mogą być inaczej rozumiane przez odbiorcę, niż zakładają to intencje nadawcy (Van Buren, 2002), co może prowadzić do potencjalnych problemów w relacji. Czy inteligencja emocjonalna może być pomocna w sytuacjach konfliktowych? Badania pokazuja, że np. w pracy grupowej inteligencja emocjonalna może być przydatna w rozwiązywaniu problemów oraz konfliktów i zwiększać poziom wykonania zadania (Jordan, Troth, 2004; Rahim, Psenicka, Polychroniou, Zhao, 2002). Znaczenie zdolności z zakresu inteligencji emocjonalnej podkreśla się również w procesach mediacji i negocjacji (Fulmer, Barry, 2004; Kelly, Kaminskienè, 2016; Kim, Cundiff, Choi, 2014). Wyższy poziom zdolności z zakresu rozumienia emocji, pozyskiwania informacji z emocji oraz zarządzania emocjami powinien być przydatny również w komunikacji osób w związkach, szczególnie w przypadku konfliktów. Badanie przeprowadzone przez Stolarskiego, Postka i Śmieję (2011) potwierdza znaczenie inteligencji emocjonalnej w rozwiązywaniu konfliktów w związku. Ciekawe jednak, że efekt dotyczył jedynie kobiet - wyższa inteligencja emocjonalna wiązała się u nich z częstszym podejmowaniem konstruktywnej lub pozytywnej strategii rozwiązywania konfliktu i unikaniem negatywnej strategii. Pozytywne i kon- 
struktywne strategie polegają m.in. na rozmawianiu o problemie, pozytywnym nastawieniu, nadziei na dojście do rozwiązania, natomiast negatywne polegaja m.in. na unikaniu rozmowy, negowaniu istnienia problemu, obwinianiu drugiej osoby (Rusbult, Johnson, Morrow, 1986). W grupie mężczyzn wykazano związki jedynie asymilacji emocji z konstruktywnymi strategiami. Podobne wyniki uzyskano w innych badaniach (np. Smith, Ciarrochi, Heaven, 2008), co może sugerować kluczowe znaczenie inteligencji emocjonalnej kobiet w rozwiązywaniu konfliktów.

\section{INTELIGENCJA EMOCJONALNA A ZAZDROŚĆ}

Zjawiskiem, które często pojawia się w związkach, jest zazdrość. Warto ja odróżnić od zawiści. Z zazdrością mamy do czynienia, gdy jesteśmy w posiadaniu jakiegoś dobra (w tym przypadku partnera) i obawiamy się jego utraty, natomiast zawiść pojawia się wtedy, gdy ktoś inny posiada to dobro i z tego powodu żywi się wobec tej osoby negatywne uczucia. Badacze wyróżniają różne komponenty zazdrości. Na przykład Pfeiffer i Wong (1989) postulują, że zazdrość w związku może przejawiać się na trzy sposoby: behawioralny (kontrolowanie i sprawdzanie partnera/partnerki), emocjonalny (reakcja emocjonalna na sytuację, gdy partner/partnerka może wejść w relację z kimś innym) lub poznawczy (obawy i podejrzenia, że partnera/partnerkę może coś łączyć z inną osoba). Aby pojawiła się zazdrość, muszą zaistnieć specyficzne okoliczności (np. pojawienie się rywala/rywalki). Taka sytuacja wywołuje podejrzenia, powoduje przeżywanie emocjonalne i może popchnąć do czynów, które moga teoretycznie zapobiec problemom w związku (większa kontrola partnera/partnerki, sprawdzanie go/jej). Z ewolucyjnego punktu widzenia zazdrość może mieć charakter przystosowawczy - chronić związek przed rozpadem i utrata partnera/partnerki, który/a przynosi korzyści dla drugiej strony i ich potomstwa (Buss, 2002). W praktyce jednak zazdrość nierzadko wiąże się z niższym zadowoleniem ze związku i niższa jego jakością (Andersen, Eloy, Guerrero, Spitzberg, 1995; Elphinston i in., 2013; Leniarska, 2020). Jak więc może pomóc $\mathrm{w}$ tym aspekcie inteligencja emocjonalna? Jedno z nielicznych badań pokazuje interesujące różnice międzypłciowe (Leniarska, 2020). Na podstawie wcześniejszych informacji o różnicach międzypłciowych w poziomie inteligencji emocjonalnej można by się spodziewać, że to kobiety będą miały przewagę nad mężczyznami w zakresie radzenia sobie z zazdrością. Tymczasem w analizach w obrębie jednostki to u mężczyzn pojawiały się istotne wyniki, podczas gdy u kobiet nie zaobserwowano istotnych korelacji (Leniarska, 2020). Wyższa in- 
teligencja emocjonalna mężczyzn wiązała się z niższą doświadczaną przez nich zazdrością poznawczą. Innymi słowy, im wyższe u mężczyzn były zdolności z zakresu zarządzania emocjami, tym mniej obawiali się oni i podejrzewali, że ich partnerka może wejść w relację z kimś innym. Jeśli jednak wziąć pod uwagę zasoby obojga partnerów, okazuje się, że wyższa inteligencja emocjonalna partnerki wiąże się z niższą zazdrością emocjonalną partnera. Może to świadczyć o tym, że posiadanie partnerki o wysokim poziomie inteligencji emocjonalnej wiąże się z niższą zazdrością emocjonalną u mężczyzny lub odwrotnie - kobieta o wyższej inteligencji emocjonalnej może szukać partnera, który „wyjściowo” będzie mniej zazdrosny (Leniarska, 2020).

\section{INTELIGENCJA EMOCJONALNA A SATYSFAKCJA ZE ZWIĄZKU}

Z przytoczonych wyników badań wynika, że inteligencja emocjonalna może zmniejszać nasilenie konfliktów w związku oraz wpływać na radzenie sobie z zazdrością. Powstaje zatem pytanie, czy może się to przełożyć również na jakość i zadowolenie ze związku? Można by się spodziewać, że takie zdolności jak poprawne odczytywanie emocji i ich regulacja moga być pomocne przy odbieraniu komunikatów partnera - sprzyjać poprawnej komunikacji, a co za tym idzie, większej satysfakcji ze związku. Podobnie w przypadku formułowania komunikatów - osoba o wyższej inteligencji emocjonalnej będzie potrafiła lepiej zapanować nad swoją ekspresją i lepiej wyrazić emocje, które odczuwa (Mayer, Salovey, Caruso, 2000).

Badania potwierdzaja powyższe przypuszczenie, wskazując na pozytywne związki inteligencji emocjonalnej z satysfakcja ze związku (Brackett i in., 2005; Malouff, Schutte, Thorsteinsson, 2014; Matczak, Knopp, 2013; Leniarska, 2020; Zeidner, Kaluda, 2008; Zeidner i in., 2013). Związki te jednak nie są tak oczywiste, jak by się wydawało. W większości badań par testowany był tzw. efekt aktora (korelacja inteligencji emocjonalnej osoby z jej satysfakcją ze związku) oraz tzw. efekt partnera (związi inteligencji emocjonalnej jednej osoby z satysfakcja ze związku drugiej). O ile efekt aktora pojawiał się we wszystkich badaniach (Brackett i in., 2005; Malouff i in., 2014; Matczak, Knopp, 2013; Leniarska, 2020; Zeidner, Kaluda, 2008; Zeidner i in., 2013), efekt partnera był rzadziej stwierdzany (Malouff i in., 2014; Leniarska, 2020; Schroder-Abe, Schütz, 2011). Osoba o wyższym poziomie inteligencji emocjonalnej może być bardziej zadowolona ze swojego związku, natomiast nie musi się to przekładać na satysfakcję partnera. Rozbieżności mogą wynikać z różnych sposobów pomiaru inteligencji emocjonalnej i satysfakcji: w badaniach samo- 
opisowych częściej obserwuje się oba efekty niż w podejściu zdolnościowym do inteligencji emocjonalnej. Badania wskazują również na pośrednicząca rolę radzenia sobie w związku przez partnerów (Zeidner i in., 2013). Co ciekawe, wysoka inteligencja emocjonalna obojga partnerów nie przekłada się na wyższa satysfakcję ze związku - jej poziom nie różni się istotnie od satysfakcji wśród par o „mieszanym” poziomie inteligencji emocjonalnej. Natomiast niska inteligencja emocjonalna obojga partnerów wiąże się z ich istotnie niższą satysfakcją ze związku (Brackett $\mathrm{i}$ in., 2005).

\section{PODSUMOWANIE}

Badania nad inteligencją pokazują, że jest ona ważną cechą w wielu obszarach życia, również w sferze funkcjonowania w związkach. Po pierwsze, ludzie wysoko cenia inteligencję u potencjalnych partnerów/partnerek. Po drugie, osoby będące w związkach charakteryzują się zazwyczaj podobnym poziomem inteligencji ogólnej, co najczęściej tłumaczy się tym, że celowo dobieramy się w pary z ludźmi zbliżonymi pod względem poziomu IQ. Te wyniki są dodatkowo wzmocnione faktem, że osoby w związku potrafią do pewnego stopnia trafnie ocenić poziom inteligencji swojego partnera / swojej partnerki. Po trzecie, badania pokazują również, że dla jakości związku ważny może być specyficzny rodzaj inteligencji - inteligencja emocjonalna. Okazuje się bowiem, że jej wysoki poziom może łagodzić konflikty, pomagać radzić sobie z zazdrością oraz zwiększać satysfakcję ze związku. Warto zauważyć, że przytoczone badania dotyczą wyłącznie związków heteroseksualnych, natomiast brakuje doniesień na temat znaczenia inteligencji (i innych czynników psychologicznych) wśród osób będących w innych związkach, np. jednopłciowych.

\section{BIBLIOGRAFIA}

Andersen, P. A., Eloy, S. V., Guerrero, L. K., Spitzberg, B. H. (1995). Romantic jealousy and relational satisfaction: A look at the impact of jealousy experience and expression. Communication Reports, 8(2), 77-85. https://doi. org $/ 10.1080 / 08934219509367613$

Bar-On, R. (1997). Bar-On Emotional Quotient Inventory: Technical manual. Toronto: MultiHealth Systems.

Barrett, L. F., Lane, R. D., Sechrest, L., Schwartz, G. E. (2000). Sex differences in emotional awareness. Personality and Social Psychology Bulletin, 26(9), 1027-1035. https://doi.org/10.1177/01461672002611001 
Borkenau, P., Liebler, A. (1993). Convergence of stranger ratings of personality and intelligence with self-ratings, partner ratings, and measured intelligence. Journal of Personality and Social Psychology, 65(3), 546-553. https://doi.org/10.1037/00223514.65.3.546

Botwin, M. D., Buss, D. M., Shackelford, T. K. (1997). Personality and mate preferences: Five factors in mate selection and marital satisfaction. Journal of Personality, 65(1), 107-136. https://doi.org/10.1111/j.1467-6494.1997.tb00531.x

Brackett, M. A., Warner, R. M., Bosco, J. S. (2005). Emotional intelligence and relationship quality among couples. Personal Relationships, 12, 197-212. https://doi. org/10.1111/j.1350-4126.2005.00111.x

Brody, L. R., Hall, J. A. (2005). Płeć, emocje i ekspresja. W: M. Lewis, J. M. HavilandJones (red.), Psychologia emocji (s. 431-445). Gdańsk: Gdańskie Wydawnictwo Psychologiczne.

Buss, D. (2002). Zazdrość - niebezpieczna namiętnossć. Gdańsk: Gdańskie Wydawnictwo Psychologiczne.

Buss, D. M., Abbott, M., Angleitner, A., Asherian, A., Biaggio, A., Blanco-Villasenor, A., ..., Yang, K.-S. (1990). International preferences in selecting mates: A study of 37 cultures. Journal of Cross-Cultural Psychology, 21(1), 5-47. https://doi. org/10.1177/0022022190211001

Darwin, C. (1871). Pangenesis. Nature, 3, 502-503. https://doi.org/10.1038/003502a0

Elfenbein, H. A., Marsh, A. A., Ambady, N. (2002). Emotional intelligence and the recognition of emotion from facial expressions. W: L. Feldman Barrett, P. Salovey (red.), The wisdom in feeling (s. 37-59). Nowy Jork-Londyn: The Guilford Press.

Elphinston, R. A., Feeney, J. A., Noller, P., Connor, J. P., Fitzgerald, J. (2013). Romantic jealousy and relationship satisfaction: The costs of rumination. Western Journal of Communication, 77(3), 293-304. https://doi.org/10.1080/10570314.2013.770161

Escorial, S., Martín-Buro, C. (2012). The role of personality and intelligence in assortative mating. The Spanish Journal of Psychology, 15(2), 680-687. https://doi. org/10.5209/rev_SJOP.2012.v15.n2.38879

Fulmer, I. S., Barry, B. (2004). The smart negotiator: Cognitive ability and emotional intelligence in negotiation. International Journal of Conflict Management, 15(3), 245272. https://doi.org/10.1108/eb022914

Furnham, A. (2009). Sex differences in mate selection preferences. Personality and Individual Differences, 47(4), 262-267. https:/ /doi.org/10.1016/j.paid.2009.03.013

Gardner, H. (1983). Frames of mind. Nowy Jork: Basic Books.

Gignac, G. E., Darbyshire, J., Ooi, M. (2018). Some people are attracted sexually to intelligence: A psychometric evaluation of sapiosexuality. Intelligence, 66, 98-111. https://doi.org/10.1016/j.intell.2017.11.009 
Gignac, G. E., Zajenkowski, M. (2019). People tend to overestimate their romantic partner's intelligence even more than their own. Intelligence, 73, 41-51. https://doi. org/10.1016/j.intell.2019.01.004

Goleman, D. (1999). Inteligencja emocjonalna w praktyce. Poznań: Media Rodzina.

Gonzaga, G. C., Campos, B., Bradbury, T. N. (2007). Similarity, convergence, and relationship satisfaction in dating and married couples. Journal of Personality and Social Psychology, 93, 34-48. https://doi.org/10.1037/0022-3514.93.1.34

Gottfredson, L. (2004). Schools and the $g$ factor. The Wilson Quarterly, 28(3), 35-45.

Hall, J. A., Matsumoto, D. (2004). Gender differences in judgments of multiple emotions from facial expressions. Emotion, 4, 201-206. https://doi.org/10.1037/15283542.4.2.201

Huston, T. L., Houts, R. M. (1998). The psychological infrastructure of courtship and marriage: The role of personality and compatibility in romantic relationships. W: T. N. Bradbury (red.), The developmental course of marital dysfunction (s. 114-151). Nowy Jork: Cambridge University Press. https://doi.org/10.1017/ CBO9780511527814.006

Jensen, A. R. (1967). Estimation of the limits of heritability of traits by comparison of monozygotic and dizygotic twins. Proceedings of the National Academy of Sciences, 58(1), 149-156. https://doi.org/10.1073/pnas.58.1.149

Jordan, P. J., Troth, A. C. (2004). Managing emotions during team problem solving: Emotional intelligence and conflict resolution. Human Performance, 17(2), 195-218. https://doi.org/10.1207/s15327043hup1702_4

Kardum, I., Hudek-Knezevic, J., Schmitt, D. P., Covic, M. (2017). Assortative mating for Dark Triad: Evidence of positive, initial, and active assortment. Personal Relationship, 24(1), 75-83. https://doi.org/10.1111/pere.12168

Kelly, E. J., Kaminskienè, N. (2016). Importance of emotional intelligence in negotiation and mediation. International Comparative Jurisprudence, 2(1), 55-60. https:/ / doi. org/10.1016/j.icj.2016.07.001

Kim, K., Cundiff, N. L. A., Choi, S. B. (2014). The influence of emotional intelligence on negotiation outcomes and the mediating effect of rapport: A structural equation modeling approach. Negotiation Journal, 30(1), 49-68. https:/ doi. org/10.1111/nejo.12045

Kirouac, G., Dore, F. Y. (1985). Accuracy of the judgment of facial expression of emotions as a function of sex and level of education. Journal of Nonverbal Behavior, 9, 3-7. https://doi.org/10.1007/BF00987555

Leniarska, M. (2020). Zwiqzek zazdrości z inteligencja emocjonalnq oraz jakościq zwiazku (Niepublikowana praca magisterska). Uniwersytet Warszawski. Warszawa. 
Luo, S., Klohnen, E. C. (2005). Assortative mating and marital quality in newlyweds: A couple-centered approach. Journal of Personality and Social Psychology, 88(2), 304-326. https://doi.org/10.1037/0022-3514.88.2.304

Makel, M. C., Kell, H. J., Lubinski, D., Putallaz, M., Benbow, C. P. (2016). When lightning strikes twice: Profoundly gifted, profoundly accomplished. Psychological Science, 27(7), 1004-1018. https://doi.org/10.1177/0956797616644735

Malouff, J. M., Schutte, N. S., Thorsteinsson, E. B. (2014). Trait emotional intelligence and romantic relationship satisfaction: A meta-analysis. American Journal of Family Therapy, 42(1), 53-66. https://doi.org/10.1080/01926187.2012.748549

Mascie-Taylor, C. G. N. (1989). Spouse similarity for IQ and personality and convergence. Behavior Genetics, 19(2), 223-227. https://doi.org/10.1007/BF01065906

Matczak, A., Knopp, K. A. (2013). Znaczenie inteligencji emocjonalnej w zyciu człowieka. Warszawa: Liberi Libri.

Matczak, A., Piekarska, J., Studniarek, E. (2005). Skala Inteligencji Emocjonalnej- Twarze (SIE-T): Podręcznik. Warszawa: Pracownia Testów Psychologicznych PTP.

Mathews, C. A., Reus, V. I. (2001). Assortative mating in the affective disorders: A systematic review and meta-analysis. Comprehensive Psychiatry, 42(2), 257-262. https:// doi.org/10.1053/comp.2001.24575

Mayer, J. D., Salovey, P., Caruso, D. R. (2000). Competing models of emotional intelligence. W: R. J. Sternberg (red.), Handbook of human intelligence (s. 396-422). Nowy Jork: Cambridge University Press.

McCrae, R. R. (1996). Social consequences of experiential openness. Psychological Bulletin, 120(3), 323-337. https://doi.org/10.1037/0033-2909.120.3.323

McCrae, R. R., Martin, T. A., Hrebícková, M., Urbánek, T., Boomsma, D. I., Willemsen, G., Costa, P. T., Jr. (2008). Personality trait similarity between spouses in four cultures. Journal of Personality, 76(5), 1137-1164. https://doi.org/10.1111/j.14676494.2008.00517.x

Petrides, K. V., Furnham, A. (2001). Trait emotional intelligence: Psychometric investigation with reference to established trait taxonomies. European Journal of Personality, 15(6), 425-448. https://doi.org/10.1002/per.416

Pfeiffer, S. M., Wong, P. T. P. (1989). Multidimensional jealousy. Journal of Social and Personal Relationships, 6(2), 181-196. https://doi.org/10.1177/026540758900600203

Rahim, M. A., Psenicka, C., Polychroniou, P., Zhao, J. H. (2002). A model of emotional intelligence and conflict management strategies: A study in seven countries. International Journal of Organizational Analysis, 10(4), 302-326. https://dx.doi. $\operatorname{org} / 10.2139 / \operatorname{ssrn} .429760$ 
Regan, P. C., Levin, L., Sprecher, S., Christopher, F. S., Gate, R. (2000). Partner preferences. Journal of Psychology \& Human Sexuality, 12(3), 1-21. https://doi. org/10.1300/J056v12n03_01

Rusbult, C. E., Johnson, D. J., Morrow, G. D. (1986). Impact of couple patterns of problem solving on distress and nondistress in dating relationships. Journal of Personality and Social Psychology, 50(4), 744-753. https://doi.org/10.1037/00223514.50.4.744

Salovey, P., Mayer, J. D. (1990). Emotional intelligence. Imagination, Cognition and Personality, 9(3), 185-211. https://doi.org/10.2190/DUGG-P24E-52WK-6CDG

Schmitt, D. P. (2002). Personality, attachment and sexuality related to dating relationship outcomes: Contrasting three perspectives on personal attribute interaction. British Journal of Social Psychology, 41(4), 589-610. https://doi. org/10.1348/014466602321149894

Schroder-Abe, M., Schütz, A. (2011). Walking in each other's shoes: Perspective taking mediates effects of emotional intelligence on relationship quality. European Journal of Personality, 25(2), 155-169. https://doi.org/10.1002/per.818

Smith, L., Ciarrochi, J., Heaven, P. C. L. (2008). The stability and change of trait emotional intelligence, conflict communication patterns, and relationship satisfaction: A one-year longitudinal study. Personality and Individual Differences, 45(8), 738-743. https://doi.org/10.1016/j.paid.2008.07.023

Stewart-Williams, S., Thomas, A. G. (2013). The ape that thought it was a peacock: Does evolutionary psychology exaggerate human sex differences? Psychological Inquiry, 24(3), 137-168. https://doi.org/10.1080/1047840X.2013.804899

Stolarski, M., Postek, S., Śmieja, M. (2011). Emotional intelligence and conflict resolution strategies in romantic heterosexual couples. Studia Psychologiczne, 49(5), 65-76. https://doi.org/10.2478/v10167-010-0041-9

Swami, V., Furnham, A., Georgiades, C., Pang, L. (2007). Evaluating self and partner physical attractiveness. Body Image, 4(1), 97-101. https://doi.org/10.1016/j.bodyim.2006.10.003

Śmieja, M. (2018). W zwiqzku z inteligencja emocjonalnq. Rola inteligencji emocjonalnej w relacjach spotecznych $i$ zwiazkach intymnych. Kraków: Wydawnictwo Uniwersytetu Jagiellońskiego.

Śmieja, M., Stolarski, M. (2018). Assortative mating for emotional intelligence. Current Psychology, 37, 180-187. https://doi.org/10.1007/s12144-016-9501-8

Van Buren, A. (2002). The relationship of verbal-nonverbal incongruence to communication mismatches in married couples. North American Journal of Psychology, 4(1), 21-36. 
Van Leeuwen, M., Van den Berg, S. M., Boomsma, D. I. (2008). A twin-family study of general IQ. Learning and Individual Differences, 18(1), 76-88. https://doi. org/10.1016/j.lindif.2007.04.006

Verbakel, E., Kalmijn, M. (2014). Assortative mating among Dutch married and cohabiting same-sex and different-sex couples. Journal of Marriage and Family, 71 (1), 1-12. https://doi.org/10.1111/jomf.12084

Watson, D., Hubbard, B., Wiese, D. (2000). Self-other agreement in personality and affectivity: The role of acquaintanceship, trait visibility, and assumed similarity. Journal of Personality and Social Psychology, 78(3), 546-558. https://doi. org/10.1037//0022-3514.78.3.546

Watson, D., Klohnen, E. C., Casillas, A., Nus Simms, E., Haig, J., Berry, D. S. (2004). Match makers and deal breakers: Analyses of assortative mating in newlywed couples. Journal of Personality, 72(5), 1029-1068. https://doi.org/10.1111/j.00223506.2004.00289.x

Zeidner, M., Kaluda, I. (2008). Romantic love: What's emotional intelligence (EI) got to do with it? Personality and Individual Differences, 44(8), 1684-1695. https:/ / doi. org/10.1016/j.paid.2008.01.018

Zeidner, M., Kloda, I., Matthews, G. (2013). Does dyadic coping mediate the relationship between emotional intelligence (EI) and marital quality? Journal of Family Psychology, 27(5), 795-805. https://doi.org/10.1037/a0034009 
Jedna z najczęściej pojawiających się w literaturze definicji inteligencji opisuje ją jako zdolność, która ułatwia człowiekowi przystosowanie do środowiska. Badania psychologiczne prowadzone już od drugiej połowy XIX w. (m.in. przez Francisa Galtona) zdają się potwierdzać adaptacyjny charakter inteligencji. Od samego początku badacze łączyli sprawność intelektualną z funkcjonowaniem szkolnym. Od samego początku badacze łączyli sprawność intelektualną z funkcjonowaniem szkolnym. W kontekście badania uczniów szkoły średniej zrodziła się koncepcja czynnika inteligencji ogólnej zaproponowana przez Charlesa Spearmana. Nowo powstałe testy inteligencji u progu XX W., początkowo stworzone dla celów edukacyjnych przez Alfreda Bineta, szybko wzbudziły zainteresowanie pracodawców, ponieważ stanowiły efektywne narzędzie wyboru najlepszych kandydatów do pracy. (...) Szkoła i praca, niewątpliwie ważne obszary aktywności człowieka, nie wyczerpują jednak dziedzin, w których inteligencja okazała się ważna. Późniejsze badania, prowadzone m.in. przez zespół szkockiego badacza lana Deary'ego, pokazały znaczenie inteligencji dla zdrowia i długości życia. Inteligencja jest ogólną zdolnością, która przesądza o sprawności funkcjonowania poznawczego człowieka. Praktycznie każda aktywność ludzka angażuje w jakimś stopniu procesy poznawcze. Nie dziwi zatem fakt, że inteligencja ma znaczenie w niemal każdej sferze życia, od samoregulacji, osobowości, przekonań o świecie, kontroli niepożądanych zachowań i emocji, po aktywność fizyczną, preferencje dobowe i funkcjonowanie w związkach. W niniejszym zbiorze przyglądamy się niektórym z tych obszarów, wskazując na różnorodność wątków związanych z inteligencją. 